University of Warwick institutional repository: http://go.warwick.ac.uk/wrap

A Thesis Submitted for the Degree of PhD at the University of Warwick

http://go.warwick.ac.uk/wrap/73124

This thesis is made available online and is protected by original copyright.

Please scroll down to view the document itself.

Please refer to the repository record for this item for information to help you to cite it. Our policy information is available from the repository home page. 


\title{
Nietzsche on Epistemology and Metaphysics
}

\author{
by
}

\section{Tsarina Doyle}

A thesis submitted in partial fulfillment of the requirements for the degree of Doctor of Philosophy in Philosophy

University of Warwick, Department of Philosophy

July 2002 
Table of Contents

Introduction

Chapter One: Nietzsche's Appropriation of Kant

Chapter Two: Nietzsche's Perspectival Theory of Knowledge

Chapter Three: Nietzsche's Emerging Internal Realism

129

Chapter Four: The Will to Power

187

Conclusion

Bibliography 


\section{Acknowledgements}

Acknowledgements to the Arts and Humanities Research Board for granting me a Fees Scholarship, 1998-2001.

Acknowledgements are also due to the University of Warwick for providing me with a "Graduate Award", 1998-2001.

Thanks are due to my supervisor, Dr. Peter Poellner, for his advice and support. 


\begin{abstract}
This thesis examines Nietzsche's philosophy as a response to Kant. I show that Kant, as interpreted by Nietzsche, dissociates epistemology and metaphysics. According to Nietzsche, the consequence of this dissociation is the collapse of Kant's transcendental epistemology into a sceptical idealism, which disables the making of positive metaphysical claims about the nature of reality. I argue that Nietzsche overcomes the dissociation of epistemology and metaphysics by rejecting Kant's distinction between constitutive, empirical knowledge and regulative, metaphysical belief. Furthermore, I show that Nietzsche rejects, what he considers to be, Kant's formalistic constitutive epistemology in favour of a regulative and interest-directed account of knowledge. I argue that Nietzsche adopts an internal realist epistemology that stipulates that our epistemic claims must be justified from within our perspectival practices of justification but that such claims must be subject to a realist constraint. Moreover, I propose that Nietzsche is justified, from within these epistemic parameters, in putting forward metaphysical claims about the nature of reality. The thesis is structured in four chapters. Chapter one examines Nietzsche's appropriation of Kant. Chapter two takes up the issue of Nietzsche's perspectivism in the context of his concerns with the issues of justification and truth. The penultimate chapter examines the emergence of Nietzsche's internal realism in his early writings. Finally, chapter four examines Nietzsche's will to power thesis where I contend that the metaphysics of the will to power is both facilitated by and compatible with his perspectivism.
\end{abstract}




\section{Introduction}

This thesis is primarily concerned to address the question of Nietzsche's epistemology and metaphysics as a response to, what he considers to be, both the partial success and ultimate failure of Kant's philosophy. I will argue that both Kant and Nietzsche share the same philosophical project, which is the desire to reconcile "knowledge and metaphysics". ${ }^{1}$ However, I will maintain that it is Nietzsche's view that Kant ultimately fails to execute this task and that Kant is responsible for positing an epistemic gap between self and world. It will be shown that Nietzsche considers that this epistemic gap results from Kant's distinction between theoretical constitutive knowledge and regulative practical belief. The thesis will set about demonstrating the manner in which Nietzsche resolves this Kantian difficulty by practicalizing Kant's epistemic programme and removing the constitutive account of knowledge that merely serves, in Nietzsche's view, to forge an opposition between self and world. This will provide the focus of my subsequent examination of both Nietzsche's perspectivism and his doctrine of the will to power. In examining these

\footnotetext{
${ }^{1}$ Friedrich Nietzsche, The Will to Power, translated by Walter Kaufmann, (New York: Vintage Books, 1968), 458 (1888). [Hereafter cited as WP] That Nietzsche aims to reconcile knowledge and metaphysics can be seen from his praise of, what he regards as, Schopenhauer's desire to reconcile "knowledge and being". (Nietzsche, "Schopenhauer as Educator", 3 in Untimely Meditations, translated by R. J. Hollingdale, (Cambridge: Cambridge University Press, 1994). That Kant shares a similar project can be discerned from his claim that

Hitherto it has been assumed that all our knowledge must conform to objects. But all attempts to extend our knowledge by establishing something in regard to them a priori, by means of concepts, have, on this assumption ended in failure. We must therefore make trial whether we may not have more success in the tasks of metaphysics, if we suppose that objects must conform to our knowledge. [Immanuel Kant, Critique of Pure Reason, translated by Norman Kemp Smith, (London: Macmillan, 1929), Bxvi, Preface to Second Edition]. Hereafter cited as CPR.
} 
doctrines we will see that Nietzsche overcomes the epistemic division of self and world by putting forward an anthropomorphic conception of knowledge that does not preclude a realist constraint. Nietzsche's particular conception of knowledge that is both anthropomorphic and realist in character will be described throughout the thesis as internal realism. This term is designed to capture what, I will argue, is Nietzsche's view that our knowledge is entwined with our specifically human interests and concerns but that our epistemic claims capture the truth about the world. We will see that Nietzsche is concerned to demonstrate that we can justifiably make objective metaphysical claims about the nature of reality from within an anthropomorphic and interest-directed conception of knowledge.

Nietzsche's reconciliation of knowledge and metaphysics can be best demonstrated by focusing on his epistemological concerns. However, throughout his writings Nietzsche castigates the traditional practice of epistemology for positing a divide between self and world. ${ }^{2}$ This divide, he contends, results from the traditional reification of the subject of knowledge and the consequent abstraction of the knowing subject from its embodied interests and practical axiological concerns in the world. Thus, it is sometimes denied that Nietzsche has any real interest in epistemological issues. If epistemology is understood in the above sense then of course it is wrong to describe Nietzsche's concerns as epistemological. However, if we take epistemology to comprise an interest in what constitutes knowledge, man's cognitive status in the world and the justification of our beliefs, then, it seems to me that it is correct to describe Nietzsche's project as epistemologically oriented in an important and 
significant sense. In this thesis we will see that Nietzsche's philosophical concerns are intertwined with those of Kant and the issue of the relationship between epistemology and metaphysics. I will argue that Nietzsche develops his consideration of the issues of truth and knowledge within the Kantian framework that prioritizes epistemology over metaphysics, but in a manner that allows him to avoid the scepticism that he associates with Kant.

By focusing on the issue of knowledge and metaphysics I take up a specific historical issue in philosophy. In the eighteenth century a debate broke out between Kant and Herder regarding the relationship between self and world. Herder was concerned to show that self and world are continuous and that both the organic and the inorganic realm can be explained by recourse to a unifying force manifest in both realms. Drawing on the work of both Leibniz and Boscovich, ${ }^{3}$ Herder postulated a continuity between the forces of nature and the forces of spirit. In so doing, he contended that reality is composed of a hierarchical organization of forces. For Herder in particular, then, and the Sturm und Drang in general the world is a living unity and an organic dynamic being.

Kant, however, took exception to Herder's project. For Kant was a representative of the Aufklärung and thus sought to uphold the Enlightenment belief in Reason. Kant argued that Herder's "force metaphysics" was an example of aestheticism in science and that it lacked the rigour and method of true scientific practice. Thus Kant complained that Herder engaged in dogmatic metaphysics.

\footnotetext{
${ }^{2}$ For Nietzsche's criticism of epistemology, see, for example, WP, 407 (1884) ff., 488 (1887) ff.

${ }^{3}$ See John H. Zammito, The Genesis of Kant 's Critique of Judgment, (London: University of Chicago Press, 1992), p. 182.
} 
Moreover, Kant argued that Herder's attempt to construe self and world as continuous devalued man's status as a rational and freely acting moral agent. Behind Kant's criticism of Herder was the desire to uphold the traditional Christian belief in God and the dignity of man.

Pivotal to the debate between Herder and Kant is the issue of the relationship between art and science. This debate can be articulated as one between NeoClassicism and Romanticism. Kant maintains that the Romantic understands art as the domain of the "genius". As such art is deemed to be extra-conceptual and extrarational. According to Kant, such aestheticism in science involves appeal to nonpropositional "revelations" that cannot be articulated for the purposes of communication and education. ${ }^{4}$ Thus, one of Kant's complaints regarding the Romantic cult of the genius is that such a manner of investigation takes place on the level of instinct rather than of Reason. ${ }^{5}$ For Kant the aesthetic belongs to the domain of Sensibility. Sensibility, for him, is the passive faculty of knowledge that is "affected" by objects. It is distinguished from both the faculties of the Understanding and of Reason. Aestheticism is then, in Kant's view, devoid of rules or conceptual form. ${ }^{6}$ Devoid of rules, aesthetic freedom is, for Kant, a mere extra-conceptual "confusion". ${ }^{7}$ He states:

\footnotetext{
${ }^{4}$ See Kant, Critique of Judgement, translated by James Creed Meredith, (Oxford: Clarendon Press, 1991), 46, p. 169. Hereafter cited as CJ.

${ }^{3}$ Ibid., 47, p. 171-2.

${ }^{6}$ Ibid., 48, p. 174.

${ }^{7}$ Kant, CPR, A90/B123.
} 
[---] shallow minds fancy that the best evidence they can give of their being full-blown geniuses is by emancipating themselves from all academic constraint of rules, in the belief that one cuts a finer figure on the back of an ill-tempered than of a trained horse. Genius can do no more than furnish rich material for products of fine art; its elaboration and its form require a talent academically trained, so that it may be employed in such a way as to stand the test of Judgement.

Only science, understood in the broad sense of rigorous scholarship and academic training, can provide, in Kant's view, this much needed conceptual form. ${ }^{9}$ Moreover, Kant argues that science must be given priority over art. ${ }^{10}$ In so doing, he attempts, in opposition to Herder, to separate science from the humanities in general. Zammito captures Kant's view when he states:

[---] Kant is questioning the justice in using the word "science" in the whole realm of the humanities as such. In other words, Kant is launching the campaign for the separation of the so-called "two cultures" by the demotion of the humanities from the rank of Wissenschaft. He writes that these "elegant sciences [schönen Wissenschaften] constitute merely the preparation in scholarship requisite for the cultivation of taste $[--]^{11}$

By arguing for the priority of science over art Kant can be seen to resist the movement in mid-eighteenth century scientific thought "from logical, mathematical,

\footnotetext{
${ }^{8}$ Kant, CJ, 47, p. 171-2.

${ }^{9}$ According to Kant, 'genius' can only be cultivated through academic training and discipline. He claims that the emphasis placed on 'originality' by the Sturm und Drang is insufficient. John Zammito captures Kant's argument as follows:
}

It is to retrieve the Zweckmässigkeit ohne Zweck whose outcome was an artistic masterpiece that one artist studies another's work. And to discern it, while vital to the appreciation, is nothing if it does not elicit in the artist a latent capacity in himself to emulate that process, to make a work of art of his own. Therefore, the only way the potential genius can be cultivated is to subject him or her to that rigorous exposure to exemplary instances of artistic genius which is just what is meant by "academic training". And hence that very "mechanical" element cannot be evaded in the cultivation of the artist. But Kant wishes to assert even more: the mechanical is not only indispensable in the cultivation of the artist, it is also indispensable in the artist's creation of a work." (Zammito, The Genesis of Kant 's Critique of Judgment, p. 141).

${ }^{10}$ In CJ, 47, p. 170 Kant states that science can be taught. He also claims that science makes progress on the path to knowledge. For these reasons he argues that science is superior to art:

[--] scientists can boast a ground of considerable superiority over those who merit the honour of being called geniuses, since genius reaches a point at which art must make a halt, as there is a limit imposed upon it which it cannot transcend.

${ }^{11}$ Zammito, The Genesis of Kant's Critique of Judgment, p. 138. 
ạbstract rationalism toward a more complex qualitative and metaphysical orientation." 12

However, Kant could not completely resist the qualitative conception of the world that was coming to the fore. Newton, who worked within the parameters of the seventeenth century mathematical and rationalist conception of science, found that this system succumbed to a number of "anomalies". The impact model of causation, Newton found, could not explain gravity. In a revision of his Optiks, then, Newton introduced the idea of force fields acting at a distance. However, Newton introduced such forces as speculative "imponderable principles" thus remaining ambiguous as to their metaphysical status. Zammito captures Newton's position when he states that

Newton recognized the existence of forces, and their vital importance to physical science, but he found it impossible to recognize them as immanent properties of particulate matter. Instead he simply termed them "etherial" or "imponderable principles" of physical action. Obviously, the term "principle" is extremely vague as to the exact nature of these phenomena, i.e., as to their substantive reality and metaphysical implications. His successors would wrestle with this question intensely in the eighteenth century. ${ }^{13}$

In contrast to Newton's hesitation with regard to the metaphysical status of force, the vitalism of such thinkers as Herder represented a move towards the substantialization of force. Herder's vitalism entailed the idea that reality, both human and natural, comprised a hierarchical organization of forces. It was precisely this move that Kant sought to resist. However, Kant recognized that appeal to force was necessary if one was to successfully avoid those anomalies in natural science experienced by Newton. Moreover, it was necessary, in Kant's view, to establish the unity of nature as a system of empirical laws. In the Critique of Pure Reason Kant argues that Reason

\footnotetext{
12 Ibid., p. 195. Zammito attributes the qualitative shift in science to Leibniz and Boscovich. (Ibid., p. 196).

${ }^{13}$ Ibid., p. 194.
} 
seeks systematic unity in nature by attempting to identify a single fundamental

force/power that unifies the diversity of individual powers:

Though logic is not capable of deciding whether a fundamental power actually exists, the idea of such a power is the problem involved in a systematic representation of the multiplicity of powers. The logical principle of reason calls upon us to bring about such unity as completely as possible; and the more the appearances of this and that power are found to be identical with one another, the more probable it becomes that they are simply different manifestations of one and the same power, which may be entitled, relatively to the more specific powers, the fundamental power. ${ }^{14}$

The notion of system evokes, for Kant, the idea of a unifying force operating purposively within nature. In this way, Kant's appeal to force can be understood in the context of his attempt to supplement mechanism with a teleological system of empirical laws. In order to both avoid dogmatic metaphysics and retain the 'dignity of man', however, Kant introduced the concept of unifying force as a regulative idea of purposiveness in nature. A regulative idea, for Kant, is a hypothetical research principle. He states in the first introduction to the Critique of Judgement, that " [-] we must necessarily presume the presence of such a unity, apart from any ability on our part to apprehend or prove its existence." 15 The regulative character of the quest for a unifying force is further brought to our attention in the Critique of Pure Reason when Kant states that

The relatively fundamental powers must in turn be compared with one another, with a view to discovering their harmony, and so to bring them nearer to a single radical, that is, absolutely fundamental, power. But this unity of reason is purely hypothetical. We do not assert that such a power must necessarily be met with, but that we must seek it in the interests of reason, that is, of establishing certain principles for the manifold rules which experience may supply to us. We must endeavour, wherever possible, to bring in this way systematic unity into our knowledge. ${ }^{16}$

\footnotetext{
${ }^{14}$ Kant, CPR, A649/B677.

${ }^{13} \mathrm{Kant}, \mathrm{CJ}$, First Introduction V, p. 24.

${ }^{16}$ Kant, CPR, A649/B677-A650/B678.
} 
allegiances, Kant claims that the concept of unifying force is a regulative principle

that guides our investigation rather than a substantial metaphysical claim about the nature of reality. ${ }^{17}$ If Kant were to attribute to the concept of force a metaphysically real status he would come close, in his view, to the dogmatic metaphysics of the vitalistic and qualitative conception of world adopted by Herder and the Sturm und

\footnotetext{
${ }^{17}$ Not all Kant scholars agree that Kant introduces the concept of force as a regulative principle. Indeed this issue has given rise to a debate in the Kant literature regarding the status of force. Some commentators read Kant's appeal to force as constitutive. Such commentators include Michael Friedman, Kant and the Exact Sciences, (Cambridge: Harvard University Press, 1994), Rae Langton, Kantian Humility: Our Ignorance of Things in Themselves, (Oxford: Clarendon Press, 1998), and Jeffrey Edwards, Substance, Force, and the Possibility of Knowledge, (London: University of California Press, 2000). By "constitutive" such scholars mean that the introduction of the concept of force is intertwined with and necessitated by Kant's constitutive epistemology of the 'Analytic'. Such commentators argue that Kant engages in an a priori deduction of the laws of natural science. The debate is a complex and difficult one. However, as Susan Neiman points out, the a priori conception of science that is presupposed by the constitutive reading is at odds with Kant's empiricist tendencies. She states:

Far from supporting a rationalist vision that would deduce the laws of science from other necessary truths, Kant's statements about the importance of observation and experiment, as well as his insistence on the incompletability of natural science, suggest a very modern view, to which the hope of an a priori deduction from transcendental principles is completely foreign. (Susan Neiman, The Unity of Reason: ReReading Kant, (Oxford: Oxford University Press, 1997), p. 55.
}

Moreover, the regulative reading, which is also supported by Gerd Buchdahl, Metaphysics and Philosophy of Science, (Oxford: Basil Blackwell, 1969) is suggested by Kant in the Second Analogy in Critique of Pure Reason:

How anything can be altered, and how it should be possible that upon one state in a given moment an opposite state may follow in the next moment - of this we have not, a priori, the least conception. For that we require knowledge of actual forces, which can only be given empirically, as, for instance, of the moving forces, or what amounts to the same thing, of certain successive appearances, as motions, which indicate [the presence of] such forces. But apart from all question of what the content of the alteration, that is, what the state which is altered, may be, the form of every alteration, the condition under which, as a coming to be of another state, it can alone take place, and so the succession of the states themselves (the happening), can still be considered a priori according to the law of causality and the conditions of time. (CPR, A207)

From the above we witness Kant's view that the categories are constitutive with regard to the form of experience. That they are regulative with regard to content (force) can be seen from his description of an Analogy:

An analogy of experience is, therefore, only a rule according to which a unity of experience may arise from perception. It does not tell us how mere perception or empirical intuition in general itself comes about. It is not a principaf constitutive of the objects, that is, of the appearances, but only regulative. [---] these analogies have significance and validity only as 
Drang. In order to avoid this threat Kant claims that we can appeal to a teleological system of empirical laws by considering nature as analogous to a divine artwork. ${ }^{18}$ In this way, he links the concept of unifying force with divine purposiveness. ${ }^{19}$ Thus in an attempt to both comprehend the purposiveness of nature and retain the dignity of man by allowing for an extra-empirical moral order, Kant projects a purposiveness beyond nature. He states that "Nature is no longer estimated as it appears like art, but rather in so far as it actually is art, though superhuman art."20

From the above we can see that the debate between Kant and Herder leaves us in a bind. If we give credence to Kant's criticism of Herder then it seems that we are only entitled to make metaphysical claims from within a strict methodological framework. However, Kant's methodology stipulates that metaphysical claims must principles of the empirical, not of the transcendental, employment of understanding [---] (CPR, A180/B223).

${ }^{18}$ In CPR Kant links the idea of God with the systematic unity of nature:

[--] the idea of such a being, like all speculative ideas, seeks only to formulate the command of reason, that all connection in the world be viewed in accordance with the principles of a systematic unity - as if all such connection had its source in one single all-embracing being, as the supreme and all-sufficient cause. [----] This highest formal unity, which rests solely on concepts of reason, is the purposive unity of things. The speculative interest of reason makes it necessary to regard all order in the world as if it had originated in the purpose of a supreme reason. Such a principle opens out to our reason, as applied in the field of experience, altogether new views as to how the things of the world may be connected according to teleological laws, and so enables it to arrive at their greatest systematic unity. The assumption of a supreme intelligence, as the one and only cause of the universe, though in the idea alone, can therefore always benefit reason and can never injure it. (CPR, A686/B714-A687/B715).

${ }^{19}$ Rae Langton's analysis of Kant's concept of force suggests the close link between this concept and the role of God in Kant's system. Langton suggests that forces represent, for Kant, extrinsic properties that are irreducible to the intrinsic properties of a substance. Forces or causal powers are said to be dependent on something other than the way a thing is, in and of itself. They are thus said to be contingent and dependent on God. For Langton tells us that, in Kant's view, "God superadds (insuper accesserit) to the monads powers of relating to each other, and this creative addition is entirely 'arbitrary' [---]". (Langton, Kantian Humility, pp. 118-119) Langton cites a number of passages from Kant's writings in support of her reading. The following is an example:

A substance never has the power through its own intrinsic properties to determine others different from itself, as has been proven. It only has the power in so far as substances are held together in a nexus through the idea of an infinite being. (cited by Langton, p. 118).

Since Kant introduces God as a regulative principle, then, it seems that the concept of force is also justified regulatively. 
be regulative and, therefore, non-cognitive in character. Moreover, Herder's metaphysics is attractive in the context of Nietzsche's aim to reconcile self and world. In this thesis we will see that Nietzsche takes up this debate. His response is to combine appropriate aspects of both Herder and Kant. He combines Herder's qualitative conception of the world with Kant's commitment to method and the need to justify our metaphysical claims.

On one level, then, Nietzsche sides with Herder and the Romantics. Firstly, he rejects Kant's theological commitments, which he claims led Kant astray. Thus he puts forward Dionysus as a decidedly anti-Christian ideal. ${ }^{21}$ That Nietzsche shares a degree of sympathy with Herder can be further seen from his praise of Goethe who cellabcrated colluded with Herder on the project regarding the continuity of the natural and the cultural. ${ }^{22}$ Goethe represents, for Nietzsche, a synthesis of sense and spirit. ${ }^{23}$ However, that Nietzsche did not completely side with the Romantics over Classicism can be discerned from his numerous criticisms of Romanticism and from his promotion of Classicism over Romanticism. ${ }^{24}$ Classicism, for Nietzsche, stands for

\footnotetext{
${ }^{20}$ Kant, CJ, 48, p. 173.

${ }^{21}$ Nietzsche, WP, 1052 (1888).

${ }^{22}$ Zammito, The Genesis of Kant 's Critique of Judgment, p. 183.

${ }^{23}$ Nietzsche, WP, 1051 (1885). Nietzsche also calls this "intelligent sensuality" [WP, 800 (1888)]. Nietzsche can thus be seen to participate in the qualitative shift mentioned earlier. John Zammito characterizes this shift as an anti-Cartesian stance:

The distinction between matter and spirit which had been the key to Cartesian thought and the interminable wrangle of philosophy in his wake (the so-called "mind-body" problem) came in the light of the new science to collapse toward a unity. (Zammito, The Genesis of Kant's Critique of Judgment, p. 196).
}

${ }^{24}$ In WP, 847 (1887), for example, Nietzsche describes Romanticism as "reactive" and Classicism as "active". Reactivity, for Nietzsche, denotes something ill constituted and weak, whilst Activity denotes health and strength.

See also WP, 848 (1887) for an example of Nietzsche's celebration of Classical 'strength', or, what he elsewhere calls the "grand style". [WP, 341 (1887-1888)]. 
logic and simplification. ${ }^{25}$ Moreover, Nietzsche maintains that the Romantics do not object to Classicism per se but rather they protest against its use of Reason as an extra-empirical legislative faculty. Nietzsche states that "The romantics in Germany do not protest against classicism, but against reason, enlightenment, taste, the eighteenth century." ${ }^{26}$ By this I take Nietzsche to mean that Romanticism protests against the legislative use of the concepts of pure Reason to the extent that these concepts are taken to be both innate and certain and, as such, to act as a normative standard of judgement. Moreover, Nietzsche argues that these legislative concepts are said to constrain reality rather than be constrained by it. This sets up a dualism of Reason and senses whereby Reason represents the standard of how things ought to be in opposition to how they actually are. ${ }^{27}$ Understood in this particular sense Nietzsche argues that the pure concepts of Reason have come to represent an extra-empirical authority. Nietzsche warns against such faith in the pure concepts of Reason when he states:

[---] they have trusted in concepts as completely as they have mistrusted the senses: they have not stopped to consider that concepts and words are our inheritance from ages in which thinking was very modest and unclear. [---] Hitherto one has generally trusted one's concepts as if they were a wonderful dowry from some sort of wonderland: but they are, after all, the inheritance from our most remote, most foolish as well as most intelligent ancestors. ${ }^{28}$

Nietzsche's comment regarding the Romantic dispute with Classicism is insightful because it indicates his view, that should the status of the pure concepts of Reason be properly modified, Romanticism and Classicism are compatible. It would seem that Nietzsche thinks that Goethe embodies the virtues of a reconciliation of these two

\footnotetext{
${ }^{25}$ Ibid., 849 (1887-1888). See also WP, 800 (1888) and WP, 799 (1888).

${ }^{26}$ Ibid., 849 (1887-1888).

${ }^{27}$ Nietzsche describes the nihilistic project of dissociating the world as it is from how it ought to be in WP, 585A (1887-1888).
} 
schools of thought. He describes Goethe as the synthetic man who is capable of, what Nietzsche terms, "disciplina voluntatis"29. Disciplina voluntatis represents, for Nietzsche, a synthesis of theoretical and practical reasoning in favour of an instinctive or embodied conception of rationality. By praising Goethe's instinctive rationality, Nietzsche rejects the legislative use of the concepts of pure Reason. The legislative view entails, according to him, that pure concepts constitute an otherwise unformed world or thing-in-itself. Such a view maintains that the world is extrinsically ordered rather than intrinsically ordered. Nietzsche's appeal to an instinctive rationality upholds the view that both the subject and its concepts are immersed within the world and that subject and world share the relationship of evolving part to larger evolving whole. ${ }^{30}$ In so doing, we will see that Nietzsche facilitates a synthesis of Kant's methodological concerns with Herder's force metaphysics. Moreover, we will also see that this synthesis makes possible the making of objective metaphysical claims from within an internal realist epistemology. Internal Realism, as already indicated, entails the view that our epistemic claims are justified from within a strict methodology, but that their justification entails their adequacy to reality.

My examination of Nietzsche's response to the debate between Classicism and Romanticism in this thesis will be issue driven. By this I mean that I will interpret Nietzsche's thought as a response to a general philosophical problem which

\footnotetext{
${ }^{28}$ Ibid., 409 (1885).

29 Ibid., 132 (1885).

${ }^{30}$ I borrow this terminology from Jay Rosenberg's One World and Our Knowledge of $I t$, (Dordrecht:

D. Reidel Publishing Company, 1980), p. 191.
} 
has particular historical roots. That an issue led analysis is a viable way to approach

Nietzsche's writings is suggested by Nietzsche himself when he states:

[--] I never attack persons; I use a person only as a strong magnifying glass with which to disclose some general critical situation. ${ }^{31}$

This is further suggested in one of Nietzsche's early unpublished notes where he informs us that

I am trying to be useful to those who are worthy of being seriously and opportunely introduced to philosophy. This attempt may or may not succeed. I am only too well aware that it can be surpassed and I wish nothing more than that I might be imitated and surpassed to the benefit of this philosophy. ${ }^{32}$

The larger philosophical issues that concern Nietzsche are that of the opposition of self and world in particular and the relation of epistemology and metaphysics in general. In so far as we can construe Nietzsche's thought as a response to Kant we will see that he shares Kant's desire to reconcile knowledge and metaphysics. Nietzsche applauds Kant's attempts to overcome both scepticism and idealism. However, we will see that Nietzsche thinks that Kant's account of knowledge is fatally flawed and that these flaws entrap him, contrary to his aims, within a sceptical idealist framework that disallows him the right to make objective metaphysical claims. We will see that Nietzsche shares Kant's concerns with the questions of method and the justification of our epistemic claims. However, Nietzsche maintains that Kant's constitutive account of knowledge and his regulative view of belief dissociate epistemology and metaphysics. Furthermore, we will see that it is

31 Nietzsche cited by Karl Jaspers, Nietzsche: An Introduction to the Understanding of his Philosophical Activity, translated by Charles F. Wallraff and Frederick J. Schmitz, (London: The John Hopkins University Press, 1997), p. 411.

${ }^{32}$ Friedrich Nietzsche, "The Philosopher" paragraph 159 in Philosophy and Truth: Selections from Nietzsche's Notebooks of the Early 1870's, edited and translated by Daniel Breazeale, (London: Humanities Press, 1993). 
Nietzsche's view that Kant's theological commitments blinker his thinking to the detriment of his philosophy as a whole.

My examination of Nietzsche's positive philosophy will centre round his perspectival theory of knowledge and the doctrine of the will to power. In so doing, I will argue that Nietzsche proffers a naturalized and pragmatic account of Kant's epistemology whereby our inquiry into the world is non-constitutive and directed by our changing needs and interests. Moreover, by extending this discussion to an analysis of the will to power thesis we will see that Nietzsche puts a methodology in place to facilitate the making of objective metaphysical claims about the nature of reality.

With this in mind it remains for me to outline the plan that the thesis will follow. The thesis will be structured in four chapters. The first chapter will set up Nietzsche's philosophy as a response to Kant. My investigation will show that Nietzsche has three interrelated issues of contention with Kant. These are the issues of form and content, the problem of the thing-in-itself and, finally, Kant's antinaturalist desire to retain belief in God, freedom and immortality. We will see that all three difficulties are reducible to the distinction between constitutive knowledge and regulative belief. By considering Nietzsche's estimation of Kant in these contexts I will demonstrate his view that Kant's philosophy induces, contrary to its own aims, a sceptical opposition between self and world. This will set the stage for the remainder of the thesis, which will examine Nietzsche's response to this issue. We will see that the introduction of his perspectivism and doctrine of the will to power provide his mature writings with the necessary tools to overcome the Kantian problem. 
My examination in chapter two will take up the issue of overcoming the epistemic gap between self and world within the context of Nietzsche's perspectival theory of knowledge. I will trace the development of Nietzsche's rejection of the constitutive account of knowledge. In particular I will address Nietzsche's rejection of metaphysical realism, which is manifested in the appearance/reality distinction. In its specifically Kantian guise metaphysical realism gives rise to sceptical idealism, which forges a separation of self and world by dissociating truth and justification. However, I will argue that Nietzsche's perspectivism, understood as an epistemic thesis, overcomes this difficulty. I will contend that his perspectivism reunites the issues of truth and justification thus overcoming the sceptical separation of knowledge and belief that he detects in Kant. In so doing, it will be seen that, for Nietzsche, our perspectives are perspectives in the world rather than constitutive of the world. We will thus witness Nietzsche's view that our perspectives are rooted within the world rather than cut off from it in the manner of the sceptical idealist.

In the third chapter I will address Nietzsche's early writings in an attempt to draw out what, I will argue, is Nietzsche's early emerging solution to the problem of the separation of self and world. I will thus divide Nietzsche's philosophical development into an "early" and "late" period. The former will include all his writings up to 1878. This will encompass both published and unpublished writings up to, but not including, Human, All Too Human. I will deem his writings during 1878 to 1901 as constitutive of his "late" period. This will include the writings from Human, All Too Human to The Will to Power. However, this division will be made in the interest of suggesting that there is continuity to Nietzsche's thought as a whole and 
that his "early" thinking can be understood as a prelude to his "later" thought. Within the period that I have designated as "early" we will see that Nietzsche considers three responses to the problem of the opposition between self and world. The first is a dogmatic realist one that claims that our human truths fail to mirror reality. In so doing, it disallows any reconciliation of self and world. However, on realizing that this view presupposes prior knowledge of the thing-in-itself, Nietzsche adopts a sceptical idealist response. This too meets with failure. However, I will argue that we can detect an emerging internal realist view that facilitates a successful reconciliation of our knowledge with the nature of reality. ${ }^{33}$ This position maintains that as knowers we are immersed within and constrained by the world in contrast to the extra-empirical subject of knowledge that Nietzsche associates with both Kant and Schopenhauer. My investigation will also include an examination of the interdependent relationship between the Apolline and the Dionysiac in The Birth of Tragedy and the relationship between art and science. With regard to the former we will see that the two Greek Gods, representing the forms of human knowledge and metaphysical truth respectively, share a reciprocal relationship rather than an oppositional one. We will further see that this reciprocity extends to the relationship between art and science where Nietzsche reconciles our normative engagement in the world with the truth about the world. In so doing, I will argue that Nietzsche's early

\footnotetext{
${ }^{33}$ In so doing, I will attempt to show, contrary to some contemporary readings of Nietzsche, that there is a continuity to Nietzsche's thought. Maudemarie Clark argues in opposition to this view that Nietzsche's writings can be divided into three distinct periods. I address this view and why I think it is untenable in chapter 2.5. [Maudemarie Clark, Nietzsche on Truth and Philosophy. (Cambridge: Cambridge University Press, 1994).]
} 
writings provide the framework in which the opposition of self and world can be overcome.

The final chapter will complete the analysis of Nietzsche's overcoming of the epistemic gap between self and world. Thus in chapter four, I will take up the question of perspectivism in relation to the doctrine of the will to power and Nietzsche's 'force' metaphysics. I will argue that the will to power is primarily an epistemic thesis that facilitates the making of objective metaphysical claims. In so doing, I will examine the will to power as incorporating both an epistemic and a metaphysical component. The chapter will be divided into two parts, the first of which will address the epistemic aspect of the will to power, and the second, which will examine Nietzsche's 'force' metaphysics. Thus part one will involve an examination of Nietzsche's views on philosophical method and explanatory economy of principles. I will argue that the will to power is best understood as a doctrine of the unity of science that attempts to unite the data of the various sciences (both human and natural sciences) to formulate a coherence theory of truth. It will be seen that the doctrine of the will to power is an explanatory realist thesis that captures Nietzsche's view that there is one world to which our perspectival truths are judged to be more or less adequate. It will be argued that such a realist view is compatible with our internal practices of justification to the extent that Nietzsche prioritizes epistemology over metaphysics in his justification of the will to power. This prioritization stipulates that adequacy is determined by correctness and justification rather than by confrontations with the world. This will provide the basis for part two where I will examine Nietzsche's 'force' metaphysics as an instance of conceptual 
change. We will see that Nietzsche's metaphysics emerges from his engagement with, and supplementation of, Boscovich's concept of force. My examination of the two aspects of Nietzsche's will to power thesis in both parts one and two will indicate that the will to power facilitates Nietzsche's successful overcoming of the "Kantian" dissociation of epistemology and metaphysics.

Before I embark upon this project there are two issues which ought to be addressed. The first relates to my decision to employ the term "metaphysics" rather than "ontology". In his recent book, Nietzsche: Naturalism and Interpretation, ${ }^{34}$ Christoph Cox has opted to employ the term "ontology" rather than "metaphysics". Cox argues that "ontology" does not carry the other-worldly implications that Nietzsche vehemently rejects and associates with traditional metaphysics. However, my decision to employ the term "metaphysics" rather than "ontology" is motivated by the desire to capture, what I will argue is, the speculative and regulative character of Nietzsche's claims about the nature of reality. ${ }^{35}$ Nietzsche's claims about the nature of reality are speculative, not in the sense that they are unjustified, but rather in the particular sense that they are not merely empirical descriptions of reality. Rather, as I will show, metaphysics constitutes, for Nietzsche, a research project guided by our interests that must ultimately be justified according to a strict methodology. Moreover, the term "metaphysics" is also designed to capture, as will be seen in chapter four, Nietzsche's emphasis on "explanation" rather than "description" in

\footnotetext{
${ }^{34}$ Christoph Cox, Nietzsche: Naturalism and Interpretation, (London: University of California Press, 1999), p. 6-7.

${ }^{35}$ John Wilcox appropriately terms Nietzsche's metaphysics a "speculative cosmology" or "metaphysics in the empirical sense". Truth and Value in Nietzsche, (Ann Arbor: The University of Michigan Press, 1974), p. 120.
} 
making objective claims about reality. Thus, my use of the term "metaphysics" is not designed to suggest that Nietzsche engages in any way in the other-worldly speculations that he castigates in Plato and Christianity.

However, the attribution of a metaphysics to Nietzsche is seen as a contentious issue in the secondary literature. There are some commentators who argue that Nietzsche's perspectivism does not entitle him to make metaphysical claims. ${ }^{36}$ Equally there is a camp within Nietzsche studies that strives to emphasize the importance of metaphysics in Nietzsche's thought. As noted by Cox, one of the

\begin{abstract}
${ }^{36}$ See, for example, Maudemarie Clark, Nietzsche on Truth and Philosophy. Clark proffers what she calls a "commonsense realist" reading of Nietzsche's perspectivist epistemology. However, she argues that his commonsense realism is incompatible with metaphysics, particularly, the type that is put forward in the cosmological version of the will to power. Arthur Danto's interpretation of Nietzsche, likewise, emphasizes Nietzsche's perspectivist epistemology over his metaphysics of the will to power. Danto argues that Nietzsche introduces realism as a supplement to his epistemology rather than as a complement. He argues that Nietzsche could not quite bring himself to embrace the possible idealist consequences of his perspectivism. Moreover he claims that because Nietzsche "wanted to say that all our beliefs are false, he was constrained to introduce a world for them to be false about." (Danto, Nietzsche as Philosopher, New York: Columbia University Press, 1980, p. 96).

Readings that emphasize Nietzsche's metaphysics and his appeal to becoming and chaos etc. are evident in the "New Nietzsche" strand of interpretation, including that of Gilles Deleuze, Nietzsche and Philosophy, translated by Hugh Tomlinson, (London: The Athlone Press, 1983). See also David B. Allison (ed.), The New Nietzsche: Contemporary Styles of Interpretation, (Cambridge: The MIT Press, 1994).
\end{abstract}

However, there have been some recent attempts to re-align Nietzsche's epistemology with his metaphysics. Peter Poellner's "Perspectival Truth" in John Richardson and Brian Leiter (eds.), Nietzsche (Oxford: Oxford University Press, 2001) argues that Nietzsche's perspectivism and his metaphysics are closely linked. Poellner re-aligns the metaphysics and the epistemology by prioritizing the former over the latter. He states:

[--] the reason why there is "only a perspectival "knowing"' (GM III. 12) is [--] that the object of knowledge - the world - is itself perspectival." (p. 86).

Mark T. Conard adopts a similar view in "Nietzsche's Kantianism", Anternational Studies in Philosophy, 33:3, 2001). He states:

I want to suggest that the reason many readers do divorce Nietzsche's epistemology from his metaphysics is that they begin with his radical epistemological claims, and from there either try to justify or explain away (or modify) his claims about the world. [---] But this is backwards. The epistemological theses follow from Nietzsche's claims about the world. (p. 30).

My thesis is also motivated by the desire to re-align Nietzsche's metaphysics and epistemology. Thus my overall approach is an inclusive one. However, as will be seen in chapter four, 1 maintain, contrary to Poellner and Conard that the epistemology precedes the metaphysics. Moreover, I claim that Nietzsche's perspectivist epistemology facilitates his metaphysics. The aim in so doing is to abandon the above mentioned trend of emphasizing either the epistemology or the metaphysics to the detriment of 
principal reasons why commentators object to the attribution of a metaphysical view to Nietzsche is that they see it as engaging in the type of other-worldly speculation that Nietzsche explicitly rejects throughout his writings. Furthermore, some commentators who emphasize what they take as the falsification involved in his perspectivism, argue that Nietzsche is not entitled to make metaphysical claims. Thus those readings that give priority to Nietzsche's perspectivism have problematized his engagement with metaphysics. On the other hand, those commentators who seek to emphasize Nietzsche's metaphysics see themselves as doing justice to the many metaphysical statements that he makes about the nature of reality, particularly his comments with regard to becoming and the will to power. This thesis will adopt an inclusive approach to the issue of the relation between Nietzsche's epistemology and his metaphysics. In so doing, I will argue that Nietzsche's metaphysics is justified within the parameters of his perspectival theory of knowledge. Moreover, the aim here is to offer a reading of Nietzsche's epistemology and metaphysics that allows them both to stand on their own two feet and be considered as independent, but compatible, doctrines. Thus I will argue that Nietzsche's perspectivism facilitates the making of objective metaphysical claims about the nature of reality. However, it will be argued that Nietzsche engages with metaphysics on a regulative rather than a constitutive level and thus that this allows for revision and discovery. By this I mean that Nietzsche's metaphysics is justified within the parameters of his perspectival theory of knowledge but not that the metaphysics itself is dependent upon his perspectivism. Nietzsche leaves open the possibility that his metaphysical

one or the other. Rather, the approach I adopt allows both Nietzsche's epistemology and his 
explanations may require modification and alteration. Such changes, however, will have to meet the same criteria of justification set down by his perspectival theory of knowledge.

The second issue that I must address is the question of the status that this thesis will attribute to those writings that were not published in Nietzsche's lifetime. There is a line of thought in contemporary Nietzsche studies that advocates that we restrict our analysis to those writings that were published in Nietzsche's lifetime. ${ }^{37}$ Bernd Magnus has gone to considerable lengths to convince us that the collection of notes posthumously published under the title The Will to Power is not a book Nietzsche had intended for publication. Magnus provides evidence for his claim that whilst Nietzsche had seriously considered publishing a book of this name, he had by September 1888 abandoned this project altogether. ${ }^{38}$ Magnus thus argues that we are not justified in formulating an understanding of Nietzsche's thought on the basis of these notes. This, he contends, is a strong reason to question any readings of Nietzsche that prioritize the notes. Magnus' argument obviously proves problematic for any thesis that wishes to address Nietzsche's epistemological and metaphysical views. For Nietzsche's thoughts on these issues are given greater attention in the posthumous material. As Richard Schacht notes, the "unpublished writings [--] contain much more of [Nietzsche's] expressed thinking on certain important matters

metaphysics to stand on their own two feet and be taken seriously on their own terms.

${ }^{37}$ See Bernd Magnus, "The Use and Abuse of The Will to Power" in Robert C. Solomon and Kathleen M. Higgins (eds.), Reading Nietzsche, (Oxford: Oxford University Press, 1990).

See also Wayne Klein, Nietzsche and the Promise of Philosophy, (Albany: State University of New York Press, 1997), pp. $181-99$ and Maudemarie Clark, Nietzsche on Truth and Philosophy, pp. 25-27.

${ }^{38}$ Bernd Magnus, "The Use and Abuse of The Will to Power", p. 225. 
than do his finished works. ${ }^{39}$ Moreover, Schacht puts forward an argument that suggests that the issue of the status of Nietzsche's unpublished writings is not so straight forward. For Schacht points out that Nietzsche's case is unusual and presents considerations that warrant a rethinking of the status of the unpublished notes. $\mathrm{He}$ argues that Nietzsche's illness was sudden and that it came upon him at a time when he had begun to publish with increasing frequency. Moreover, Schacht maintains that the notebooks were the workshop for Nietzsche's published writings and thus that these notes provide some clue to what would have been Nietzsche's future compositions. $^{40}$

There is, however, a more philosophical reason that warrants use of the posthumous material in formulating an interpretation of Nietzsche. This thesis, while acknowledging the concerns of Magnus and others, takes the view that any issue led reading of Nietzsche is obliged to consider the posthumous writings in a serious and detailed way. My reasons for this view center round my contention that Nietzsche is primarily a philosopher who is concerned to address philosophical issues. In so doing, Nietzsche attempts to get inside a philosophical problem, so to speak, and to address this particular problem by embodying multiple perspectives with regard to it. Nietzsche's writings are then, in my view, very much the writings of a working philosopher. As Walter Kaufmann maintains, Nietzsche's unpublished notes allow us "to look, as it were, into the workshop of a great thinker." only puts himself to work. He also labours his readers through his unsystematic and

\footnotetext{
${ }^{39}$ Richard Schacht, Nietzsche, (London: Routledge and Kegan Paul, 1983), pxii.

${ }^{40}$ Richard Schacht, Making Sense of Nietzsche: Reflections Timely and Untimely, (Chicago: University of Illinois Press, 1995), pp. 118-119.
} 
aphoristic writing style. Nietzsche encourages his readers to engage with philosophy by forcing the reader to occupy the various perspectives that he himself has occupied. Moreover, he forces his readers to organize these perspectival thoughts into a coherent structure. Thus Nietzsche's writings, as Karl Jaspers points out, engage his readers in a creative and constructive fashion by encouraging them to philosophize themselves. ${ }^{42}$ This implies that Nietzsche's writings as a whole are intended by him to be a workshop for his readers. If this is the case, then, it is difficult to formulate a convincing argument to demote the philosophical status of the posthumous material, which were arguably the contents of his own workshop. Furthermore, the style that Nietzsche adopts in the posthumous material is not dissimilar to that employed by him in the published writings. Even if Magnus is correct that he had abandoned his plan to publish a book called The Will to Power, that does not mean that the individual notes are not valid perspectives on a particular topic that concerned Nietzsche. The posthumous notes are significant to the extent that they are indicative of the types of problems that occupied Nietzsche and of the range of solutions that he considered. To the extent that Karl Jaspers is correct that Nietzsche intended his readers to be working philosophers, then, this approach to the posthumous writings is justified. I am thus in agreement with Cox when he states:

Like the notebooks, the published works contain relatively brief discussions and remarks that rarely, if ever, exhaust or provide Nietzsche's definitive view on any given issue. Instead, as in his notebooks, Nietzsche's published work continually revisits earlier themes, issues, and problems, adding new insights and perspectives in piecemeal fashion. The large mass of material left in the notebooks provides a wealth of such insights and perspectives on which we can draw in constructing our interpretations of Nietzsche. And, while we can never be sure just how much or what parts of this material Nietzsche fully endorsed or intended for publication,

\footnotetext{
${ }^{41}$ Editor's introduction to Walter Kaufmann's translation of the Will to Power, xvi, xiv-xv.

${ }^{42}$ See Karl Jaspers, Nietzsche: An Introduction to the Understanding of his Philosophical Activity, especially Introduction.
} 
responsible use of the notebooks as a supplement to Nietzsche's published work gives us a much broader and deeper view of his philosophical thinking than a purist restriction to the published texts alone could provide. ${ }^{43}$

It is on this note that I will begin examining Nietzsche's reconciliation of knowledge and metaphysics. I will proceed by now turning to his estimation of Kant in chapter one.

${ }^{43}$ Cox, Nietzsche: Naturalism and Interpretation, pp. 10-11. 


\section{Chapter One}

\section{Nietzsche's Appropriation of Kant}

We laugh as soon as we encounter the juxtaposition of "man and world," separated by the sublime presumption of the little word "and." (The Gay Science, 346)

\subsection{Introduction}

In "Schopenhauer as Educator", Nietzsche praises the reconciliation of "knowledge" and "being" as a philosophical project. ${ }^{1}$ Although he attributes this project to Schopenhauer in this early work, the reconciliation of knowledge and metaphysics is a task with which Nietzsche tirelessly engaged throughout his entire philosophical career. If we follow the development of Nietzsche's thought we will see that his approach to the question alters as his thinking on the matter develops. However, it is clear that the question remains the same. In this chapter we will see that Nietzsche's project of reconciling knowledge and metaphysics is intertwined with both his appraisal and reworking of Kant's epistemology.

It is sometimes argued that Nietzsche had only a second-hand knowledge of Kant and thus that his comments on Kant are not to be treated with any considerable importance. However, as I shall demonstrate, it is clear from some of Nietzsche's

\footnotetext{
${ }^{1}$ Friedrich Nietzsche, "Schopenhauer as Educator", 3, in Untimely Meditations, translated by R. J. Hollingdale, (Cambridge: Cambridge University Press, 1994). Nietzsche attributes the project of reconciling knowledge and being to Schopenhauer. However, Schopenhauer had maintained that the thing-in-itself could be known through the collapse of the principle of individuation. It has been suggested that Nietzsche shares a similar project in his earliest writing, The Birth of Tragedy. I will delay any treatment of Nietzsche's early relationship to Schopenhauer until chapter three. In this chapter I aim to focus on Nietzsche's more "mature" response to this question. It is, therefore, sufficient to note
} 
notebook entries that he had a sufficient understanding of Kant to render his own reworking of the Kantian programme a legitimate project. In saying this, we must stress that Nietzsche's reworking of Kant is always a reworking of a particular philosophical problem that Nietzsche thinks is exemplified in Kant's writings. Thus it can be argued that Nietzsche is not so much interested in the historical Kant but rather with a set of philosophical difficulties that can be broadly termed Kantian in character. With this in mind I will attempt to tease out what these "Kantian" difficulties are. We will see that there are three main difficulties that Nietzsche raises with regard to Kant. The first pertains to Kant's constitutive epistemology and the status of the categories as the form that is imposed on experience. We will see that Nietzsche attributes to Kant the idea that pure form can be imposed on an intrinsically formless content and, moreover, that Nietzsche was unhappy with this view. I shall call this the Form-Content problem. Secondly, Nietzsche maintains that Kant's retention of the thing-in-itself transcends our epistemic boundaries and illegitimately makes room for Kant's moralism. This will be simply referred to as the problem of the thing-in-itself. Thirdly, Nietzsche is equally dissatisfied with Kant's evocation of faith and morality and the manner in which it induces, according to Nietzsche's particular interpretation of Kant, a dissociation of knowledge and belief. I will refer to this as Kant's anti-naturalist thesis. ${ }^{2}$ Nietzsche argues that the problem of form and content along with both the problem of the thing-in-itself and Kant's anti-

here that Nietzsche remained concerned to reconcile knowledge and being throughout his early and late thought.

${ }^{2}$ Kant attempts to cater for belief in God, freedom and immortality. He states that "I have found it necessary to deny knowledge, in order to make room for faith." (Immanuel Kant, Critique of Pure Reason, translated by Norman Kemp Smith, (London: Macmillan, 1929), Bxxx. Hereafter cited as CPR. 
naturalist thesis results in "epistemological skepticism"3. Moreover this scepticism gives rise, in Nietzsche's view, to a severance of the theoretical from the practical. ${ }^{4}$ Nietzsche articulates his general description of Kant's philosophy when he states:

The movement back to Kant in our century is a movement back to the eighteenth century: one wants to regain a right to the old ideals and the old enthusiasm - for that reason an epistemology that "sets boundaries," which means that it permits one to posit as one may see fit a beyond of reason."

In what follows I will proceed to examine the manner in which Nietzsche links the above three difficulties to Kant. Thus in section two I will briefly outline each of the three problems. In the third section I will suggest that the scepticism that Nietzsche attributes to Kant is initiated by both the specific problem of the thing-initself and, what Nietzsche considers to be, Kant's formalistic epistemology. The penultimate section will take up the issue of scepticism with regard to Kant's distinction between constitutive knowledge and regulative belief. For we shall see that this distinction facilitates Kant's separation of the theoretical and the practical and, in Nietzsche's view, paves the way for Kant's anti-naturalism. It is against this background that I will turn to the final section. Here I will examine the manner in which Nietzsche attempts to overcome the "Kantian" scepticism by re-establishing a relationship between knowledge and belief. In so doing, the final part of this chapter will investigate the manner in which Nietzsche thinks that he can overcome Kant's difficulties by reworking the Kantian programme from the inside. This will involve an examination of Nietzsche's rejection of Kant's constitutive epistemology in favour

\footnotetext{
${ }^{3}$ Friedrich Nietzsche, The Will to Power, translated by Walter Kaufmann, (New York: Vintage Books, 1968), 101 (1887). Hereafter cited as WP.

${ }^{4}$ Ibid., 458 (1888).
} 
of practical regulative ideas that develop and change according to our engagement with the world. This notion of regulative principles of justification will bring us to Nietzsche's particular form of realism that rejects the unknowable Kantian thing-initself but manages to maintain a realist position that constrains our epistemic claims. ${ }^{6}$

Moreover, my examination of Nietzsche's relationship to Kant in this chapter will provide the necessary background for an investigation into both Nietzsche's perspectivism and the doctrine of the will to power in subsequent chapters. With this in mind I will now proceed to examine Nietzsche's appraisal of Kant.

\subsection{Nietzsche's Appraisal of Kant}

That Nietzsche's thinking is intimately intertwined with that of Kant can be seen from the fact that his comments with regard to Kant are not entirely negative. This suggests that Nietzsche's thinking developralongside his understanding of the Kantian project. In his earliest writing, The Birth of Tragedy, Nietzsche has the utmost praise for Kant's philosophical achievements, which amount, in Nietzsche's view, to setting limits to conceptual and logical knowledge thus curbing rationalist hubris:

[---] great and universally minded spirits have, with incredible level-headedness, used the armoury of science to point out the limitations and determinations of knowledge, and have thus

\footnotetext{
${ }^{5}$ Nietzsche, WP, 95 (1887).

${ }^{6}$ Thus it will be seen that Nietzsche advances his task of reconciling knowledge and metaphysics as a naturalist project in general and an anti-theological project in particular. He states:

[---] to return man to nature; to master the many conceited and gushing interpretations and secondary meanings that have heretofore been scribbled and painted over that eternal original text homo natura; to ensure that henceforth man faces man in the same way that currently, grown tough within the discipline of science, he faces the other nature, with unfrightened Oedipus-eyes and plugged Odysseus-ears, deaf to the seductive melodies of the old metaphysical bird-catchers [---] [Friedrich Nietzsche, Beyond Good and Evil, translated by Marion Faber, (Oxford: Oxford University Press, 1998), 230. Hereafter cited as BGE].

The precise meaning of Nietzsche's naturalism will be made clearer at the end of the chapter where we will see that naturalism, in a broad and general sense, denotes, for Nietzsche, a cognitive affinity between self and world.
} 
decisively negated the claims of science to universal validity and universal goals. In so doing, they have revealed the delusion, based on the principle of causality, which imagines it can explain the innermost essence of things. The tremendous courage and wisdom of Kant and Schopenhauer carried off the most difficult victory: victory over the optimism that lurked within the essence of logic, which in turn forms the basis of our culture. Where that optimism had believed that all the mysteries of the world could be known and explained, relying on apparently innocuous aeternae veritates, and had treated space, time, and causality as utterly unconditional and universal laws, Kant revealed how these in fact only served to transform mere phenomena, the work of Maya, into the sole true essence of things, and thus render true knowledge of that essence thoroughly impossible. ${ }^{7}$

From the above citation we can see that, according to Nietzsche, Kant's views concerning the legitimate theoretical employment of the concepts of the Understanding and his theory of space and time as transcendental conditions of the possibility of knowledge, serve to limit our knowledge to knowledge of phenomena or appearances. In so doing, Kant denies us pure conceptual access to how things are in themselves. In a revealing passage in The Gay Science Nietzsche explicitly links his own thought to Kant when he maintains that Kant initiated the project of setting limits to knowledge:

Let us recall [---] Kant's tremendous question mark that he placed after the concept of "causality" - without, like Hume, doubting its legitimacy altogether. Rather, Kant began cautiously to delimit the realm within which this concept makes sense (and to this day we are not done with this fixing of limits). ${ }^{8}$

Nietzsche's claim here that Kant's project has not yet been completed suggests that his own philosophical project is very much entwined with his estimation of the Kantian enterprise. As John Wilcox remarks, correctly I believe,

Whatever hard words he may have had for Kant as moralist and Christian, his own views, especially epistemological, are unintelligible apart from the problems Kant forced upon the nineteenth century or from Kant's contributions to Nietzsche's solutions to these problems.

\footnotetext{
${ }^{7}$ Friedrich Nietzsche, The Birth of Tragedy, translated by Shaun Whiteside, (London: Penguin, 1993), $18 \mathrm{pp} .87-8$. Hereafter cited as BT.

${ }^{8}$ Friedrich Nietzsche, The Gay Science, translated by Walter Kaufmann, (New York: Vintage Books, 1974), 357. Hereafter cited as GS.

9 John Wilcox, Truth and Value in Nietzsche, (Ann Arbor: University of Michigan Press, 1974), p. 99.
} 
However, Nietzsche's praise for Kant comes with reservations. He argues that Kant ultimately restricts our "knowledge" to appearances in order to allow him to make reference to an extra-empirical realm. Thus Kant's appeal to an epistemic limit has, according to Nietzsche, both positive and negative consequences. The positive entails establishing the empirical world as an object of knowledge whilst the negative involves a sceptical dissociation of such knowledge from how things are in themselves. To understand how this dissociation takes place we must ascertain how Nietzsche understands Kant's epistemology. This will involve a brief outline of the three difficulties that Nietzsche attributes to Kant.

The first difficulty is that of form and content. In The Will to Power, 530 Nietzsche raises the Form-Content issue that he associates with Kant. In this passage Nietzsche addresses Kant's concern to establish the possibility of synthetic a priori judgements. Nietzsche sees Kant's conception of synthetic a priori judgements as founded on the idea of giving form to experiential content. He argues that Kant "presupposes that there is not only "data a posteriori" but also "data a priori":

Necessity and universality can never be given by experience! Thus they are independent of experience, prior to all experience! That insight that occurs a priori, therefore independently of all experience, out of sheer reason, is "a pure form of knowledge"! [---- $]^{10}$

In this passage Nietzsche presents, as he sees it, Kant's dualist postulation of a pure $a$ priori element and an a posteriori element as the ultimate constituents of knowledge. That Nietzsche is critical of this dualism can be discerned from his rejection of both rationalism and "sensualism". Nietzsche rejects rationalism as a form of dogmatism that claims that Reason has unmediated cognitive access to ultimate reality. 
Rationalism, according to Nietzsche, bypasses sense-experience in its pursuit of knowledge. Strict empiricism/sensualism, however, fares no better in Nietzsche's eyes. The empiricist, particularly the Humean variety, with its emphasis on the content of experience, arguably neglects form by reducing it to a mere psychological association of ideas. For both the rationalist and the empiricist, then, form and content are potentially separable opposites rather than symbiotic, essentially interdependent, partners. ${ }^{11}$ The two doctrines are then, in Nietzsche's view, two sides of the one coin. In rejecting both views Nietzsche maintains that we cannot separate form from content in this way. By examining another passage we again receive indication that Nietzsche's bone of contention with Kant centers round the difficulty of imposing a priori form on a posteriori content. In this passage Nietzsche suggests, contrary to the view he attributes to Kant, that sensations as the data of experience are already injected with form before their assimilation under the judgement of the cognitive subject:

There could be no judgments at all if a kind of equalization were not practiced within sensations: memory is possible only with a continual emphasizing of what is already familiar, experienced. $^{12}$

Thus Nietzsche takes issue with Kant's claimed pure $a$ priori status of the categories. By considering the role of the categories in this way Kant puts forward a constitutive account of knowing. The constitutive account maintains that the cognitive subject

\footnotetext{
${ }^{10}$ Nietzsche, WP, 530 (1883-8).

"See Nietzsche, Human, All Too Human, translated by Marion Faber and Stephen Lehmann, (London: Penguin, 1994), 1, [Hereafter cited as HAH], BGE, 2 and Twilight of the Idols, translated by Duncan Large, (Oxford: Oxford University Press, 1998), III.6, [Hereafter cited as Twilight], for Nietzsche's rejection of the metaphysics of opposites.
} 
constitutes the object of knowledge through the injection of pure a priori form on $a$ posteriori content. By introducing this constitutive conception Kant attempts to render the object co-extensive with our knowledge. However, as we shall see later, Nietzsche thinks that Kant's constitutive epistemology is unable to facilitate a reconciliation of knowledge and metaphysics. Moreover, Nietzsche suggests that even if Kant's separation of form and content were not itself problematic, his attempted reconciliation of knowledge and metaphysics would still be thwarted by two further difficulties. As already indicated these are the problem of the thing-initself and Kant's anti-naturalism.

Nietzsche argues that Kant's attempt to reconcile knowledge and metaphysics is incompatible with his retention of the thing-in-itself that transcends the boundaries of our knowledge. For it is Nietzsche's view that the thing-in-itself introduces an extra-empirical realm that merely serves to dissociate our human truths from how things are in themselves. He suggests that the very reference to an extra-empirical realm casts doubt upon the epistemic status of our ordinary empirical claims to knowledge ${ }^{13}$ It is for this reason that Nietzsche suggests that what Kant considers to be "knowledge" cannot properly be accredited with any epistemic status. Nietzsche claims that Kantian "knowledge" is devoid of epistemic weight when he states that "judgment is a belief that something is thus and thus! And not knowledge!" 14 Nietzsche thus articulates his view that Kant does not give us knowledge at all but

\footnotetext{
${ }^{12}$ Nietzsche, WP, 532 (1885). For Nietzsche on rationalism see BGE, Preface and 16. For sensualism see BGE, 12 and 15. For Humean empiricism as a rejection of the synthetic a priori see WP, 530 (1883-1888).

${ }^{13}$ See HAH, 16 where Nietzsche states that there is no epistemic connection between things-inthemselves and the realm of appearances.
} 
only realistically unconstrained beliefs. This can be seen more clearly if we consider Nietzsche's use of the terms "belief" and "knowledge."

Nietzsche defines "beliefs" as "provisional assumptions". ${ }^{15}$ By this I take him to mean that "beliefs" are tools that direct inquiry. Whether our "beliefs" are to be accredited with epistemic merit depends on what we mean by the term "knowledge". Nietzsche defines the term "knowledge" in both a negative and positive way. Taken in the negative and, in Nietzsche's view, particularly Kantian sense, "beliefs" are denied epistemic merit. The negative definition suggests that if knowledge is taken to be co-extensive with either Kant's constitutive account of knowledge or with thingsin-themselves (which Kant claims are unknowable anyway), then knowledge is a fruitless goal. Nietzsche puts forward the view that the categories can neither constitute an object nor provide knowledge of things-in-themselves. That Nietzsche thinks that Kant has claimed an illegitimate constitutive role for the categories can be gleaned from the following passage where he suggests that Kant's categories should really be construed as regulative beliefs:

"The basic laws of logic, the law of identity and the law of contradiction, are forms of pure knowledge, because they precede all experience."- But these are not forms of knowledge at all! They are regulative articles of belief. [my emphasis] ${ }^{16}$

That Nietzsche thinks that the very reference to the thing-in-itself as an extraempirical and unconditioned realm is illegitimate can be seen from his positive perspectival account of knowledge:

\footnotetext{
${ }^{14}$ Nietzsche, WP, 530 (1883-1888).

is Ibid., 497 (1884).

${ }^{16}$ Ibid., 530, (1883-1888). It is to be noted here that Nietzsche does not recognize Kant's distinction between formal and transcendental logic.
} 
Coming to know means "to place oneself in a conditional relation to something"; to feel oneself conditioned by something and oneself to condition it - it is therefore under all circumstances establishing, denoting, and making-conscious of conditions (not forthcoming entities, things, what is "in-itself"). ${ }^{17}$

It is in the context of the negative and positive use of the term "knowledge" that we can now understand Nietzsche's claim that all Kant gives us are beliefs and not knowledge. Beliefs are denied any epistemic status if knowledge is understood in the constitutive sense above or if it is equated with cognition of things-in-themselves. However, once the above negative definitions of knowledge are abandoned our beliefs can be accredited, in Nietzsche's view, with a more positive epistemic value. They become tools of inquiry and the perspectival lens through which we view the world. Thus Nietzsche states:

There is only a perspectival seeing, only a perspectival "knowing"; and the more affects we allow to speak about a matter [---] that much more complete will our "concept" of this matter, our "objectivity" be. ${ }^{18}$

Considering this, then, it seems that Nietzsche's claim that Kant's synthetic a priori judgements are beliefs rather than knowledge must be seen as Nietzsche's rejection of a particular account of knowledge that he associates with Kant. Nietzsche argues that Kant's "negative" account of knowledge (that is, both the constitutive account and knowledge as represented by the thing-in-itself) is designed for the purpose of making room for the anti-naturalist ideals of God and morality. This is the third difficulty that Nietzsche attributes to Kant. According to Nietzsche's understanding of the anti-naturalist thesis, Kant has limited knowledge in order to make room for

\footnotetext{
${ }^{17}$ Ibid., 555 (1885-6)
} 
the old rationalist beliefs in God and morality on a non-cognitive level. Nietzsche claims that Kant's project is one in which "moral ontology is the dominant prejudice". ${ }^{19} \mathrm{He}$ argues that Kant's emphasis on practical philosophy is designed to serve, what he calls, Kant's "moral fanaticism". ${ }^{20}$ Nietzsche thus maintains that Kant attempts to retain the old ideals by default. Moreover, he links Kant's anti-naturalist thesis to the retention of the unknowable thing-in-itself:

[T]o create room for his "moral realm" [Kant] saw himself obliged to posit an indemonstrable world, a logical "Beyond" - it was for precisely that that he had need of his critique of pure reason! In other words he would not have had need of it if one thing had not been more vital to him than anything else: to render the "moral realm" unassailable, even better incomprehensible to reason [---]. ${ }^{21}$

In the course of our examination as a whole we will see that the main difficulty that Nietzsche considers stems from Kant's philosophy and that unites the three problems outlined above, is the problem of how the world can be said to feature in our epistemic claims. We will see that it is Nietzsche's view that the three difficulties combine to make it impossible within the confines of Kant's philosophy that appearances grasp the world adequately. Thus Nietzsche characterizes Kant's philosophy in "Schopenhauer as Educator" as a "despair of truth" that leads to both scepticism and relativism. $^{22}$

To recapitulate, then, I have briefly indicated the three principal difficulties that Nietzsche detects in Kant. The first was the Form-Content problem whereby

\footnotetext{
${ }^{18}$ Nietzsche, On the Genealogy of Morality, translated by Maudemarie Clark and Alan J. Swensen, (Indianapolis: Hackett Publishing Company, 1998), III, 12. Hereafter cited as GM.

${ }^{19}$ Nietzsche, WP, 530 (1883-1888).

${ }^{20}$ Ibid., 95 (1887).

${ }^{21}$ Friedrich Nietzsche, 1886 Preface to Daybreak: Thoughts on the Prejudices of Morality, translated by R. J. Hollingdale, (Cambridge: Cambridge University Press, 1993), 3.

${ }^{22}$ Friedrich Nietzsche, "Schopenhauer as Educator", 3 in Untimely Meditations.
} 
form and content are treated as potentially separable opposites. The second was the problem of the thing-in-itself, which in Nietzsche's view, introduces an extraempirical realm in comparison with which what Kant takes to be knowledge is ultimately denied epistemic merit. The third was Kant's anti-naturalism, which stems from Kant's reference to the thing-in-itself and the need to limit knowledge. Each of these problems, as we have seen, are closely linked and intertwined. By examining Nietzsche's

each of these issues in more detail we will see that Kant is caught in a bind from which he is ultimately unable to extricate himself. I will suggest that the above three difficulties are incompatible with Kant's aim to render knowledge and metaphysics coextensive and, moreover, that they induce a sceptical separation of self and world. The sceptical issue will initially be brought into greater focus in our next section by examining both the Form-Content problem and Kant's anti-naturalist appeal to God and morality, through the optics of the problem of the thing-in-itself. This will bring to our attention Nietzsche's view that Kant's distinction between constitutive knowledge and regulative belief is at the heart of Kant's philosophical difficulties. This will then provide the framework in which I will examine Nietzsche's appropriation and modification of Kant in the final section. I will now proceed with this investigation by turning to Nietzsche's estimation of the problem of the thing-initself and its transcendence of epistemic boundaries.

\subsection{The Issue of Boundaries and the Problem of the Thing-In-Itself.}

We have seen that Nietzsche praises Kant for having delimited the realm in which we are entitled to employ the concept of causality. This concept is limited to the 
phenomenal realm or the realm of appearance. However, Nietzsche was not long in realizing that Kant's limitation of knowledge to appearances would only lead to problems. For appearances, in Kant's thought, are distinguished from things-inthemselves. The most prominent difficulty with Kant's reference to things-inthemselves, in Nietzsche's view, is that it permits Kant's anti-naturalist programme of allowing Christian faith in through the back door. ${ }^{23}$ In particular, Nietzsche objects to Kant's positing of a supersensible moral realm to house the ideas of God, freedom and immortality. ${ }^{24}$ In the following passage Kant articulates his justification for employing the concept of the thing-in-itself:

Now let us suppose that the distinction, which our Critique has shown to be necessary, between things as objects of experience and those same things as things in themselves, had not been made. In that case all things in general, as far as they are efficient causes, would be determined by the principle of causality, and consequently by the mechanism of nature. I could not, therefore, without palpable contradiction, say of one and the same being, for instance the human soul, that its will is free and yet is subject to natural necessity, that is, is not free. For I have taken the soul in both propositions in one and the same sense, namely as a thing in general, that is, as a thing in itself; [----] But if our Critique is not in error in teaching that the object is to be taken in a twofold sense, namely as appearance and as thing-in-itself; [---] then there is no contradiction in supposing that one and the same will is, in the appearance, that is, in its visible acts, necessarily subject to the law of nature, and so far not free, while yet, as belonging to a thing in itself, it is not subject to that law, and is therefore free. ${ }^{25}$

By limiting our knowledge to appearances thus debarring cognitive access to the thing-in-itself, Kant allows us regulative belief in God. He claims that to consider

${ }^{23}$ Christian ideals, according to Nietzsche, are life-denying ideals that ought to be rejected:

Dividing the world into a 'real' [Währe] one and an 'apparent' [scheinbare] one, whether in the manner of Christianity, or of Kant (a crafty Christian, when all's said and done), is but a suggestion of décadence - a symptom of declining life--- (Nietzsche, Twilight, III.6. See also GS, 335 and GM, 11I, 25).

${ }^{24}$ Nietzsche charges that the thing-in-itself is merely a depersonalized conception of God:

One has unlearned the habit of conceding to this posited ideal the reality of a person; one has become atheistic. But has the ideal itself been renounced? - At bottom, the last metaphysicians still seek in it true "reality," the "thing in itself" compared to which everything else is merely apparent. It is their dogma that our apparent world, being so plainly not the expression of this ideal, cannot be "true" - and that, at bottom, it does not even lead us back to that metaphysical world as its cause. The unconditional, representing the highest perfection, cannot possibly be the ground of all that is conditional. [Nietzsche, WP, 17 (1887-1888)]. 
God as an object of knowledge leads to antinomies and contradictions. However, he argues that by positing God as a regulative idea of the systematicity of nature we can avoid such contradictions. In so doing, God is posited as an object of thought rather than an object of knowledge. In subsequent chapters we will see that one of the reasons that Kant's appeal to the regulative belief in God is unsatisfactory is that such an appeal is, for Nietzsche, explanatorily superfluous. Kant maintains that the regulative idea of the systematic unity of nature can be correctly termed God or nature. ${ }^{26}$ Nietzsche contends that if this is the case, then, it is just as satisfactory to eliminate all appeal to God as an explanatory device. However, I will return to this issue of explanatory economy of principles in greater detail in chapter four. For the moment it is sufficient that we note that Nietzsche challenges the validity of the Kantian regulative move here because it entertains supersensible ideas that have traditionally undermined the reality of the empirical world with which we are familiar. Thus Nietzsche claims that the employment of supersensible ideas is illegitimate because they, in his view, legislate against the empirical world of our experience. Moreover, this is particularly lamentable because Kant's project had, in Nietzsche's view, the potential to avoid this nihilistic conclusion. Nietzsche writes that Kant

[---] had obtained the "thing in itself" by stealth [---] and was punished for this when the "categorical imperative" crept stealthily into his heart and led him astray - back to "God," "soul," "freedom," and "immortality," like a fox who loses his way and goes astray back into his cage. Yet it had been his strength and cleverness that had broken open the cage! ${ }^{27}$

\footnotetext{
${ }^{25}$ Kant, CPR, Bxxvii-Bxxviii.

${ }^{26}$ Ibid., A699/B727. Kant states "[---] it must be a matter of complete indifference to us, when we perceive such unity, whether we say that God in his wisdom has willed it to be so, or that nature has wisely arranged it thus."

${ }^{27}$ Nietzsche, GS, 335.
} 
Here Nietzsche argues that Kant initiates a project that Kant himself does not complete. Kant's project, he suggests, promised to remove the appearance/reality divide thus elevating the realm of appearance to the realm of reality. However, Kant's reference to the thing-in-itself, Nietzsche argues, re-instates this dichotomy. Nietzsche claims that the retention of the thing-in-itself in whatever guise threatens us with scepticism and relativism. It threatens, he argues, to lock our empirical claims to knowledge within a strict anthropomorphism that has no connection to reality. He maintains that the concept of the thing-in-itself as an unconditioned thing debarts us access to the real world thus rendering the world with which we are experientially acquainted a realm of possible illusion and falsehood. Thus Nietzsche maintains that the concept of the thing-in-itself as the concept of an unconditioned thing does not even feature in the realm of appearance:

[---] stricter logicians, after they had rigorously established the concept of the metaphysical as the concept of that which is unconditioned and consequently unconditioning, denied any connection between the unconditioned (the metaphysical world) and the world we are familiar with. So that the thing-in-itself does not appear in the world of appearances, [my italics], and any conclusion about the former on the basis of the latter must be rejected. ${ }^{28}$

Here Nietzsche argues that the thing-in-itself cannot provide our epistemic claims with a realist constraint because Kant's conception of the thing-in-itself is an extratheoretical understanding of reality. Such an understanding evokes the idea of a God's Eye View that transcends our specifically human capacity for knowledge. Furthermore, the appearance/reality distinction passes sentence on the realm of appearance by considering it less valuable than that of an inaccessible "true" realm. In the light of these difficulties Nietzsche takes his task to be the completion of the

\footnotetext{
${ }^{28}$ Nietzsche, HAH, 16.
} 
promised Kantian programme. This completion process must eliminate, as Nietzsche sees it, the metaphysical excesses of Kant's retention of the thing-in-itself. Furthermore, Nietzsche must execute this task by engaging with the Kantian enterprise modifying it from the inside rather than rejecting it altogether. From the above, we can see that this will involve taking seriously Kant's attempt to limit knowledge to appearances in a way that facilitates these appearances being appearances of an accessible reality that is not an incognizable thing-in-itself. ${ }^{29}$ This is part and parcel of what Nietzsche considers to be his task when he praises the philosophical project of reconciling knowledge and being. He sets about executing this task by demonstrating the incoherency of the very notion of a thing-in-itself construed along Kantian lines.

Nietzsche argues that Kant's transcendental project of restricting our knowledge to appearances renders any appeal to an extra-conceptual thing-in-itself illegitimate:

The sore point of Kant's critical philosophy has gradually become visible even to dull eyes: Kant no longer has a right to his distinction "appearance" and "thing-in-itself - he had deprived himself of the right to go on distinguishing in this old familiar way, in so far as he rejected as impermissible making inferences from phenomena to a cause of phenomena - in accordance with his conception of causality and its purely intra-phenomenal validity $-{ }^{30}$

From this we can see that Nietzsche attributes to Kant the view that things-inthemselves "cause" us to have certain sensations that are then synthesized by the constitutive character of the Understanding to formulate an "appearance". Things-in-

\footnotetext{
${ }^{29}$ Nietzsche writes:

It seems to me important that one should get rid of the all, the unity, some force, something unconditioned; otherwise one will never cease regarding it as the highest court of appeal and baptizing it "God". One must shatter the all; unlearn respect for the all; take what we have given to the unknown and the whole and give it back to what is nearest, what is ours. [Nietzsche, WP, 331 (1883-1888)].

${ }^{30}$ Ibid., 553 (1886-1887).
} 
themselves are understood by this reading to relate to appearances in terms of the affection of the former on our Sensibility. However, Nietzsche maintains that Kant is not justified in holding such a view because the critical limits that Kant has established with regard to all knowledge entails that the concept of causality is legitimately employed only within the realm of possible experience which is the realm of appearance. The thing-in-itself as situated outside these parameters cannot, therefore, be known to act as the cause of our appearances. Although some commentators have heavily disputed this reading, ${ }^{31}$ it is suggested by some of Kant's own, though far from unambiguous statements. In the following passage, for example, Kant stresses the importance of the role of affection:

[I]ntuition [---] is only possible [---] in so far as the mind is affected in a certain way. The capacity (receptivity) for receiving representations through the mode in which we are affected

${ }^{31}$ Gerd Buchdahl maintains that when Kant appeals to the thing-in-itself, the transcendental object and appearances, he is not appealing to different objects but rather to one epistemological object under different interpretations. [Gerd Buchdahl, Kant and the Dynamics of Reason, Essays on the Structure of Kant's Philosophy, (Oxford: Blackwell, 1992)] Borrowing from Husserl, Buchdahl terms Kant's employment of these terms a "reduction-realization" process. Buchdahl's interpretation is a complicated and sophisticated one and is supported by Kant's explicit denial in the Preface to the Second Edition of CPR that the thing-in-itself represents a second object. (CPR, Bxxvii). Buchdahl's interpretation is somewhat similar to that put forward by Ernst Cassirer and the School of Marburg. Cassirer maintains that the thing-in-itself is a mobile epistemological concept that has a meaning within Kant's system that is not an independent metaphysical meaning. As a mobile concept its meaning is determined by what Rotenstreich calls the "shifting perspectives of the advance of knowledge" [Nathan Rotenstreich, Experience and its Systemization: Studies in Kant, (The Hague: Martinus Nijhoff, 1965), p. 159]. As a functional concept it stands for "a content being built, a meaning undergoing transformation. Its content is not only determined within a structure - but also varies with, and in virtue of, the structure." (Rotenstreich, p. 159) Thus according to this reading the concept of the thing-in-itself plays different roles in the "Aesthetic", the "Analytic" and "Dialectic" of the Critique of Pure Reason. In the "Aesthetic" its role is to emphasize the passivity of sensation. In the "Analytic" it is transformed into the transcendental object where its epistemological role is a negative one that serves to emphasize the difference between thought and knowledge or the difference between a pure concept and the concept that merges with intuition in synthesis. In the "Dialectic" "the concept of the thing-in-itself stands for the regulative function of reason; not reason as really or actually knowing, but reason as harboring the inner power and inner direction of advance and of perpetual building of the structure of knowledge" (Rotenstreich p. 161).

However, it is not necessary for me to consider this reading in detail here because as mentioned earlier Nietzsche's understanding of Kant is a historically rooted one and I am interested in Kant only to the extent that he poses problems for Nietzsche. 
by objects, is entitled sensibility [----] The effect of an object upon the faculty of representation, so far as we are affected by it, is sensation. ${ }^{32}$

Strictly speaking, the thing-in-itself cannot, according to the criteria set out in the above citation, be the cause of our sensations because the thing-in-itself is not properly speaking an object for Kant. Sometimes Kant refers to the thing-in-itself as "nothing to us" and so of no cognitive value. An object is something of cognitive value and is the product of the synthesizing activity of the mind. However, Kant complicates the issue by suggesting in the following passage that the thing-in-itself is responsible for our sensations:

[---] I say that things as objects of our senses existing outside us are given, but we know nothing of what they may be in themselves, knowing only their appearances, i.e., the representations which they cause in us by affecting our senses. ${ }^{33}$

And again in The Critique of Pure Reason, Kant states:

How things may be in themselves, apart from the representations through which they affect us, is entirely outside our sphere of knowledge. ${ }^{34}$

Nietzsche receives his particular historically rooted interpretation of Kant and the problem of the thing-in-itself from Schopenhauer. Moltke Gram points out that according to Schopenhauer, Kant's appeal to the thing-in-itself is either a selfcontradiction or a misnomer. Its contradictory nature can be detected, in Schopenhauer's view, by examining the very notion of a thing-in-itself. If the thingin-itself is to be properly called a thing then it must be a possible object of experience and so stand under the category of causality and exhibit the characteristics of spatiality and temporality. However, this is incompatible with maintaining, according

\footnotetext{
${ }^{32}$ Kant, CPR, A19-20/B33-4.

${ }^{33}$ Kant, Prolegomena to Any Future Metaphysics, translated by Paul Carus, (Cambridge: Hackett Publishing Company, 1977), 13 remark II, p. 33.

${ }^{34}$ Kant, CPR, A190/B235.
} 
to Schopenhauer, that the thing exists in and for itself. This would entail that it is

unknowable and thus that it is not causally active and that it lacks the characteristics

of the forms of our Sensibility. Schopenhauer states:

[---] if a thing-in-itself is to be assumed, it cannot be an object at all, which, however, he always assumes it to be; but such a thing-in-itself would have to lie in a sphere toto genere different from the representation (from knowing and being known), and therefore could least of all be inferred according to the laws of the connexion of objects among themselves. ${ }^{35}$

Equally, Schopenhauer maintains that if the Kantian thing-in-itself is not selfcontradictory then it must be understood as a misnomer for a material object. Kant refers to material objects as appearances. Moltke Gram articulates the dilemma detected by Schopenhauer in the following:

Emphasize its relation to material things and their causation of sensations and you make it indistinguishable from a material object. Emphasize its lack of causal relations to the material things of our world and its lack of spatial or temporal characteristics and you have transformed what was supposed to be an object into an empty concept. ${ }^{36}$

Furthermore, if Kant were to claim that the object that affects Sensibility is an appearance/empirical object, he would be led into a circular argument whereby "appearance" would be both the cause and the result of affection. From this it seems that Nietzsche's problem with regard to the thing-in-itself is to some extent justified.

${ }^{35}$ Arthur Schopenhauer, The World as Will and Representation, Volume I, translated by E. F. J. Payne, (New York: Dover, 1966), Appendix, p. 503. Hereafter cited as WWR, I.

${ }^{36}$ Moltke Gram, "Things in Themselves: The Historical Lessons" in Journal of the History of Philosophy, 1980, p. 415. Schopenhauer thinks that the concept of the thing-in-itself is meaningful to the extent that it can be intuited directly as Will. However, within a strictly Kantian framework it becomes, in Schopenhauer's view, a meaningless concept:

Kant's principal result may be summarized in its essence as follows "All concepts which do not have as their basis a perception in space and time (sensuous perception), or in other words, have not been drawn from such a perception, are absolutely empty, that is to say, they give us no knowledge. But as perception can furnish only phenomena, not things-in-themselves, we too have absolutely no knowledge of things-in-themselves." [Arthur Schopenhauer, The World as Will and Representation, Volume II, translated by E. F. J. Payne, (New York: Dover, 1966), p. 196. Hereafter cited as WWR, II].

However, as we shall see in the remainder of this chapter, Kant thinks that he can nevertheless give a regulative meaning to the thing-in-itself. 
The difficulty surrounding the cogency of the concept of the thing-in-itself throws Kant's realist pretensions into disarray. According to Kant, the thing-in-itself is required as an object of thought to put at bay the threat of idealism. He argues that it must be possible to think the thing-in-itself to ensure that "we have experience and not merely imagination of other things. ${ }^{, 37}$ However, if we can only think the thing-initself rather than know it, then, it seems that the thing-in-itself cannot act as any real form of constraint and so cannot put at bay the threat of both idealism and scepticism. The only constraint possible, then, must come from, in Kant's view, the cognitive subject. Kant, therefore, puts forward a constitutive account of knowledge that entails a constraint "from within". However, a difficulty arises, as we shall soon see, because Kant's constraint from within serves to emphasize the role of form and minimize the role of affective content, thus re-opening the threat of idealism and scepticism that he wants to avoid.

This threat can be seen if we consider the role of transcendental apperception and synthesis in Kant's account of the unity of the object. R. P. Wolff argues that

A manifold of representations of an object has a unity for as Kant says [---], "they must necessarily agree with one another (untereinander ubereinstimmen)". But this unity cannot be, as we might at first suppose, the unity in the object of the states represented by the manifold of perceptions, for the object is hidden from us, and hence we could never have any knowledge at all. On the assumption that we do have knowledge, therefore, we must seek the unity elsewhere. If we cannot discover the unity on the side of the object, then perhaps we can discover it on the side of the subject. Perhaps, that is, the manifold has a unity simply qua mental contents. ${ }^{38}$

By so looking to the subject as the source of unity of our representations, Kant provides both a regressive and progressive argument to link the unity of

\footnotetext{
37 Kant, CPR, B275.

38 Robert Paul Wolff, Kant's Theory of Mental Activity, (Cambridge, Massachusetts: Harvard University Press, 1969), p. 140.
} 
consciousness with the possibility of empirical knowledge. The regressive argument takes the assumption of knowledge as its starting point whilst the progressive argument begins with the unity of consciousness. Both arguments meet each other in the concept of the transcendental object (epistemological object), which is deemed to have "universal applicability to the contents of consciousness". ${ }^{39}$ Beginning with the regressive argument, then, Kant addresses the possibility of synthetic a priori knowledge. In so doing, he seeks the characteristic that distinguishes, what Wolff terms, "a cognitively valid judgment from an arbitrary juxtaposition of representations". ${ }^{40}$ Since there is nothing in the representations themselves that links them together, the source of their unity, Kant argues, must lie in the idea that they are representations of the same object. However, Kant points out that we cannot seek this object beyond our representations because any object that lies beyond this boundary is a mere object of thought and thus can never be an object of knowledge. The source of the unity of our representations, according to the regressive argument, therefore, must be attributed to the concept of the object. Kant states that "It is easily seen that this object must be thought only as something in general $=\mathrm{x}$, since outside our knowledge we have nothing which we could set over against this knowledge as corresponding to it". ${ }^{41}$ Thus he maintains that the source of the unity of our representations must be sought in the concept of the object rather than in the object itself. The progressive argument descends, as Wolff articulates, "from the unity of

\footnotetext{
${ }^{39}$ Ibid., p. 112.

40 Ibid., p. 113.

${ }^{41}$ Kant, CPR, Al04.
} 
consciousness to the universal applicability of the concept of the object" ${ }^{42}$ This unity of consciousness is, according to Kant, the "I think" which accompanies all of my representations. He states:

"It must be possible for the "I think" to accompany all my representations; for otherwise something would be represented in me which could not be thought at all and that is equivalent to saying that the representation would be impossible, or at least would be nothing to me". ${ }^{43}$

The unity of consciousness entails the association of the contents of consciousness in the sense that our representations are bound together as contents of one mind. In his discussion of transcendental apperception in the Subjective Deduction we see that apperception produces this unity of the contents of consciousness according to rules. Kant states that it "forms out of (macht aus) all possible appearances, which can stand alongside one another in one experience, a connection of all these representations according to laws". ${ }^{44}$ This unity is thus made possible by the application of the concept of the object, which Kant informs us, "is always, as regards its form, something universal which serves as a rule. ${ }^{945}$ The mind operates on the manifold according to the rules of synthesis, in Kant's view, and the resulting synthetic unity is the unity of apperception. Thus transcendental apperception is the transcendental condition of the possibility of objects of experience. However, it may be argued that the epistemic constraint represented by Kant's account of transcendental apperception is not as subjective as it at first seems. For it could be objected at this point that, in Kant's system, the subject and the object make each other possible and that this reciprocity thesis reconciles the subject and the object in a

\footnotetext{
${ }^{42}$ Wolff, Kant's Theory of Mental Activity, p. 115.

${ }^{43}$ Kant, CPR, B 131-2.

${ }^{44}$ Ibid., A 108

${ }^{45}$ Ibid., A106.
} 
way that Nietzsche fails to recognize. Let us consider this for a moment. The subject, for Kant, makes the object possible through the injection of synthetic unity into the object of knowledge. Kant states that "it is the unity of consciousness that alone constitutes the relation of representations to an object" ${ }^{46}$ Equally, the object is said to make the subject possible because self-consciousness is attained through my awareness of myself as the source of the unity of the object. Here we can see that both the subject and the object are constituted by the act of synthesis. However, it would seem that Kant's account of synthesis allows only for a subjective constraint rather than a realist one. This can perhaps be seen more clearly by briefly outlining Kant's account of the threefold synthesis where, I shall now suggest, Kant emphasizes a formal over a material constraint. ${ }^{47}$

Kant claims that synthesis of the manifold takes place in three stages, each of which is attributed to a different faculty of the mind. These three stages are "apprehension of the representations in intuition; then reproduction of them in imagination; and finally, recognition of the reproduced representations in a concept." 48 The first stage is the process whereby a "given manifold of intuition, having a temporal ordering, is first held together as a manifold" ${ }^{49}$ Kant argues that the manifold "must first be run through, and held together" ${ }^{\text {s0 }}$ in order that a unity of

\footnotetext{
${ }^{46}$ Ibid., B137.

${ }^{47}$ Schopenhauer also argues that Kant fails to attend to the issue of content satisfactorily. He states that After the detailed discussion of the universal forms of all perception given in the Transcendental Aesthetic, we necessarily expect to receive some explanation of its content [-] But about this the whole of Kant's teaching really contains nothing but the oft-repeated meaningless expression: "The empirical part of perception is given from without." (Schopenhauer, WWR, I, Appendix, p. 438).

${ }^{48}$ Wolff, Kant's Theory of Mental Activity, p. 150.

49 Ibid., p. 150.

${ }^{30}$ Kant, CPR, A99.
} 
intuition should arise from this manifold. However, as Wolff points out, this would seem to be the second stage of the synthetic process whereby the manifold is reproduced by the imagination. Therefore Wolff claims that the second stage of the process is actually the first:

[---] a careful reading of the text reveals that the synthesis of reproduction is a condition of the synthesis of apprehension, for the way in which the manifold is "run through, and held together" (A 99) is precisely by reproducing it. Hence the synthesis of reproduction should have been placed first in the three-fold synthesis. ${ }^{31}$

This is further suggested by Kant's claim that "The synthesis of apprehension is thus inescapably bound up with the synthesis of reproduction". 52 This leads to further complications, according to Wolff, regarding "how much of the structure of experience is ascribable to intuition and how much to synthesis". ${ }^{33}$ Wolff, in a footnote to his examination of Kantian synthesis, argues that this has been a longstanding problem in philosophy:

The problem which Kant faces is a perennial one in philosophy. If one distinguishes a formal and material element in cognition, and if one identifies the formal with the conceptual, then it will always appear paradoxical to say anything about the material element. Whatever one says will be expressed by means of concepts, and hence will fall on the side of the formal. Eventually, the material becomes ineffable and indeterminate. The next step, which is frequently taken by the disciples of such a philosophy, is to drop out of the material element altogether, since it plays no assignable role. Thus Kant's theory tends to degenerate into an idealism, $a$ la Hegel or Fichte, in which the mind generates its own world without the aid of a given manifold of intuition. ${ }^{34}$

This problem regarding the role of content pertains to the difficulty surrounding the relation between epistemology and metaphysics. Kant's epistemological project had

\footnotetext{
${ }^{51}$ Wolff, Kant's Theory of Mental Activity, p. 151.

${ }^{52}$ Kant, CPR, A102.

${ }^{53}$ Wolff, Kant's Theory of Mental Activity, p. 151. Of course, this would not have been a problem for Kant if he had not so stringently separated form from content. However, it is to be noted that the reading of Kant given here is more akin to the transcendental psychology type than to the epistemic conditions type proffered by Strawson and others. [See, for example, P. F. Strawson, The Bounds of Sense, (London: Routledge, 1991) and Henry B. Allison, Kamt's Transcendental Idealism, (London: Yale University Press, 1983)]. The reason for this again is to offer a plausible account of Nietzsche's possible understanding of Kant. In so doing, however, I am not claiming that this a definitive reading of Kant but rather a reconstruction of Kant along Nietzschean lines.
} 
set about to render the epistemological object and the metaphysical object coterminous. He states:

There are only two possible ways in which synthetic representations and their objects can establish connection, obtain necessary relation to one another, and, as it were, meet one another. Either the object alone must make the representation possible, or the representation alone must make the object possible. ${ }^{55}$

Wolff explains that the aim of Kant's epistemological turn is to render the realm of knowledge coterminous with the realm of being. In other words, the epistemic turn involves demonstrating that the constitutive principles of the Understanding permeate the empirical level and thus that they are coextensive with the object. According to Kant, the significance of his epistemic turn resides in its reversal of the degree of priority given to the object of knowledge over the forms and conditions of knowledge. Previously, Kant maintains, the emphasis had been placed on the object and the question had centered round the issue of how the object can be said to make itself known. Prior to Kant's epistemic turn, then, metaphysics was given priority over epistemology. Kant's epistemic turn claims to reverse this order of priority to the extent that epistemology is prioritized over metaphysics. Thus the question becomes for Kant that of explaining how the subjective conditions of our knowledge make the object known. Wolff articulates the significance of Kant's view when he states that "The a priori representations determine what can and cannot be known as an object [--] The realms of being and knowledge are coterminous, and even more significantly, the latter defines the former." 56 We have already seen that it is also Nietzsche's aim to reconcile knowledge and metaphysics. However, Nietzsche thinks

\footnotetext{
${ }^{54}$ Ibid., p. 152n.

${ }^{55}$ Kant, CPR, A92.

${ }^{56}$ Wolff, Kant's Theory of Mental Activity, pp. 97-8.
} 
that Kant has failed to execute this aim. I have suggested that the price that Kant must pay in order to achieve a reconciliation of the object and the concept is the elimination of the epistemic role of content in a way that threatens to undermine the role of the a posteriori. Kant, however, is aware of the difficulty. This is made clear in his introduction of the regulative ideas of Reason as principles of empirical research. However, we will see that Kant's introduction of regulative principles to deal with the problem of content ultimately fails. For we will see that Kant's introduction of the said regulative principles opens up a division between theory and practice and, in so doing, opens up a gap between epistemology and metaphysics that he is ultimately unable to overcome. I will proceed to demonstrate this by now turning to Kant's account of the constitutive principles of the Understanding and the regulative ideas of Reason. In so doing, I will further address the problem of form and content that Nietzsche detects in Kant. We will see that Kant's constitutive/regulative distinction ultimately impedes his aim to reconcile knowledge and metaphysics because neither constitutive nor regulative principles, in Nietzsche's view, are able to grant an epistemic role to content.

\subsection{Kant on Constitutive and Regulative Principles}

In this section I will examine the extent to which Nietzsche's claim that Kant separates cognitive subjects irredeemably from the world has some merit. I have already examined the strength of this claim with regard to the very broad distinction between appearances and things-in-themselves. I have also examined Kant's epistemic turn and the suggestion that this turn emphasizes form over content. In so 
doing, I suggested that the epistemic turn initiated an epistemic gap that Nietzsche wants to overcome. Here I will proceed to examine this epistemic turn in more detail. This will involve looking at Kant's conception of the constitutive principles of the Understanding and the regulative maxims of Reason. In so doing we will see that ultimately the constitutive principles are unsuccessful in closing the epistemic gap. Furthermore, I will suggest that Kant's employment of regulative ideas of Reason as a response to this difficulty also prove unsuccessful. On reaching this conclusion I will then turn my attention to Nietzsche and the manner in which he attempts to remedy the Kantian dilemma by practicalizing Kant's entire programme.

Wolff's explanation of Kant's epistemological turn in the previous section suggested that the aim of the turn was to render metaphysics and epistemology coterminous. I have already remarked on the similarity of this project to Nietzsche's aim of reconciling knowledge and metaphysics. With regard to Kant, we have seen that this reconciliation requires that the constitutive character of the Understanding permeate or capture empirical content to the extent that form can be said to be intrinsic to content rather than imposed upon and extrinsic to it. However, in my examination of Kant's account of transcendental apperception and synthesis we saw that Kant's overemphasis on the form of experience entailed the elimination of the epistemic role of content. The emphasis or element of constraint was for Kant in that context an a priori one that threatened to strangle the a posteriori. Although Kant claims that one of his aims has been to overcome both idealism and scepticism by 
reconciling knowledge and metaphysics ${ }^{57}$, Nietzsche suggests that Kant has failed to achieve these goals. Thus in many passages throughout his writings, Nietzsche refers to Kant as a relativist and sceptic. It is not obviously clear from Nietzsche's writings why he thinks that this is the case. In order to ascertain the reasons, a certain amount of investigative work is required on our part. By considering some of those few passages and throw-away remarks that Nietzsche makes with regard to Kant we can, I believe, put forward a convincing argument to suggest that Nietzsche thinks that the constitutive/regulative distinction is at the heart of Kant's failure. This is particularly brought to our attention when Nietzsche claims that Kant's categories should be regulative articles of belief rather than constitutive principles. I will cite this passage once more for the convenience of the reader:

"The basic laws of logic, the law of identity and the law of contradiction, are forms of pure knowledge, because they precede all experience" - But these are not forms of knowledge at all! They are regulative articles of belief. ${ }^{58}$

Thus we must proceed by now looking to Kant's distinction between the constitutive principles of the Understanding and the regulative maxims of Reason.

Kant's distinction between constitutive and regulative principles divides the Critique of Pure Reason into approximately two halves, the first part dealing with the constitutive principles of knowledge and the second half with ideas of Reason. The latter are introduced by Kant to supplement the former. ${ }^{59}$ Yet it is brought to our attention as early as the second preface that Kant limits the role of the constitutive

\footnotetext{
${ }^{57}$ Kant, CPR, Bxxxiv-Bxxxv.

${ }^{58}$ Nietzsche, WP, 530 (1883-1888). Furthermore, Nietzsche maintains that "The categories are 'truths' only in the sense that they are conditions of life for us" [WP, 515 (1888)].

59 Kant, CPR, A648/B676. Kant states that the function of reason "is to assist the understanding by means of ideas, in those cases in which the understanding cannot by itself establish rules [---]".
} 
principles to allow him to introduce the ideas of God and freedom as regulative ideas or practically warranted beliefs. ${ }^{60}$ Thus Kant maintains that he has found it necessary to limit knowledge in order to allow room for faith. It is with this in mind that Nietzsche brands Kant an underhanded Christian, claiming that Kant slipped his antinaturalist views in through the back door. Briefly put, constitutive principles are said to ascertain what is rather than what ought to be. A constitutive principle, as Stanley French points out, "describes" the sensible world and its instances are said to be verifiable. ${ }^{61}$ Constitutive principles are captured in Kant's conception of the synthetic a priori. The pure a priori categories are said to be both constitutive of experience and constrained by the possibility of experience. However, I detected difficulties with this notion earlier when I suggested that the constraint involved here is formal rather than empirical. Regulative principles, on the other hand, are said to transcend what immediate experience can verify. Such principles are, in Kant's view, principles of research that seek systematic unity in nature. He states:

[---] this regulative capacity [---] goes far beyond what experience or observation can verify; and though not itself determining anything, yet serves to mark out the path towards systematic unity. ${ }^{62}$

The constitutive principles, according to Kant, furnish us with experience of what he also refers to as "nature", ${ }^{63}$ whilst the regulative principles supplement such furnishings by ordering "nature" into a systematic unity. Thus Kant maintains that

\footnotetext{
${ }^{60}$ I follow Nicholas Rescher in calling Kant's regulative ideas practically warranted beliefs. See Nicholas Rescher, Kant and the Reach of Reason, (Cambridge: Cambridge University Press, 2000), p. 141.

61 Stanley G. French, "Kant's Constitutive-Regulative Distinction”, in Lewis White Beck (ed.), Kant Studies Today, (lllinois: Open Court, 1969), p. 376. We will see in chapter three that Nietzsche reconciles the "is" and the "ought to be" by arguing that art and science share a reciprocal relationship. ${ }^{62}$ Kant, CPR, A668/B696.

${ }^{63}$ Ibid., Al14.
} 
just as the Understanding works upon and synthesizes Sensibility, Reason works upon and orders the deliverances of the Understanding. He states:

Reason presupposes the knowledge which is obtained by the understanding and which stands in immediate relation to experience, and seeks for the unity of this knowledge in accordance with ideas which go far beyond all possible experience. ${ }^{64}$

Kant's introduction of the regulative ideas of Reason in the 'Appendix to the Transcendental Dialectic' in the Critique of Pure Reason and the two introductions to the Critique of Judgement, indicate that there is perhaps some deficiency inherent in the constitutive principles. In the previous section, I suggested that this deficiency arose in the context of the relationship between constitutive principles and empirical content. The constitutive limitations of the categories when it comes to empirical content, and the need for a regulative supplement, is indicated in Kant's distinction between mathematical principles (Quantity and Quality) and dynamical principles (Relation and Modality). The mathematical principles are said to be constitutive with regard to intuition (pure intuition) whilst the dynamical principles are constitutive only with respect to experience and regulative with respect to intuition. The regulative ideas of Reason are said to be regulative of experience in general. In the

'Appendix to the Transcendental Dialectic' Kant states:

In the Transcendental Analytic we have distinguished the dynamic principles of the understanding, as merely regulative principles of intuition, from the mathematical, which, as regards intuition, are constitutive. None the less these dynamical laws are constitutive in respect of experience, since they render the concepts, without which there can be no experience, possible a priori. But the principles of our reason can never be constitutive in respect of empirical concepts; for since no schema of sensibility corresponding to them can ever be given, they can never have an object in concreto. ${ }^{65}$

\footnotetext{
${ }^{64}$ Ibid., A662/B690.

${ }^{65}$ Ibid., A664/B692.
} 
The dynamical principles are constitutive with respect to experience to the extent that they "make the concepts without which no experience takes place possible a priori". They thus provide the form of all experience. However, the important point for our examination is that they are not constitutive with respect to intuition. The dynamic principles are regulative with regard to the empirical content of our knowledge. When Kant talks of the mathematical principles as constitutive he means that they are constitutive with respect to non-empirical content which in this case is pure intuition that abstracts from all sensation. The categories of the Understanding can only be understood as regulative with respect to empirical content, which Kant calls empirical intuition. The full implications of this will be seen shortly in my examination of Kant's response to Hume. For the present it is enough to note that besides the synthetic a priori truth status that Kant claims for mathematics his project merely provides the form of our experience whilst the relation of form to content can only be a regulative one.

It is perhaps in this sense that we can appreciate Nietzsche's comment that Kant's categories should really be regulative articles of belief. Moreover, we also have an insight into Nietzsche's claim that Kant's synthetic a priori judgements are only applicable to mathematical propositions and not to empirical content. Nietzsche argues that Kant has shown that synthetic a priori judgements are possible in mathematics but that they are not possible in experience. Thus Nietzsche attributes to Kant the view that "Mathematics is possible under conditions under which 
metaphysics is never possible. All human knowledge is either experience or mathematics. [my emphasis] $]^{366}$

However, we have already seen that Nietzsche endorses Kant's project of rationally justifying the objective applicability of the concept of causality in the face of Humean objections. ${ }^{67}$ Nietzsche's interest in this particular aspect of the Kantian project is significant for two reasons. Firstly, an examination of Kant's response to Hume lends further weight to Nietzsche's suggestion that Kant's constitutive account of knowledge provides only the form of experience and that its relation to content is regulative. Secondly, Nietzsche's endorsement of Kant's response to Hume indicates the regulative procedure that Nietzsche himself will adopt in his attempt to reconcile knowledge and metaphysics. I will examine the first reason in the remainder of this section taking up Nietzsche's own regulative approach in the final section. Thus I will continue by turning to Kant's response to Hume.

In the Critique of Pure Reason, Kant maintains that his critical philosophy is not so much concerned with objects as with their cognition. Thus he argues that his transcendental deduction of the categories is properly concerned with the question of right (Quid Juris) rather than fact (Quid Facti). In so doing, Kant argues that he wishes to find a middle ground between, what he considers to be Locke's transcendence of the bounds of experience, and Humean scepticism. ${ }^{68}$ Humean

\footnotetext{
${ }^{66}$ Nietzsche, WP, 530 (1883-1888).

${ }^{67}$ In GS, 357 Nietzsche states:
}

Let us recall [---] Kant's tremendous question mark that he placed after the concept of "causality" - without, like Hume, doubting its legitimacy altogether. Rather, Kant began cautiously to delimit the realm within which this concept makes sense (and to this day we are not done with this fixing of limits).

${ }^{68}$ Kant, CPR, B 127. According to Kant, Locke invalidly derives all concepts from experience and then "goes so far in the use of them as to assert that we can prove the existence of God and the immortality 
scepticism maintains, according to Kant, that we are "unable to explain how it can be possible that the understanding must think concepts, which are not in themselves connected in the understanding, as being necessarily connected in the object.",69 Hume had argued that we have no experience of causal necessity and that therefore the belief in causal relationships is based on habit and custom rather than on insight into the "secret powers" of nature. Thus although Hume acknowledges that we have the "idea" of cause and necessary connection, he denies that the objective application of this idea is rationally justified. Stroud articulates Hume's view as follows:

Because of the mind's natural tendency to 'spread itself on external objects, when we get a 'feeling of determination' we then come to project necessity onto the objective relations between events in the world, and thus come to believe, mistakenly, that there are objective necessary connections between events. ${ }^{70}$

It is precisely Hume's denial that the objective applicability of the concept of causality is rationally justified that Kant challenges. Kant maintains that Hume incorrectly argued from the premise, that because experience does not allow us to establish necessary causal connections directly, to the conclusion, that the objective application of the concept is not rationally justified. That this is Kant's reading of Hume's view can be discerned from the following passage:

If, therefore, wax, which was formerly hard, melts, I can know a priori that something must have preceded, ([that something being] for instance [in this case] the heat of the sun), upon which the melting has followed according to a fixed law, although a priori, independently of experience, I could not determine, in amy specific manner, either the cause from the effect, or the effect from the cause. Hume was therefore in error in inferring from the contingency of our determination in accordance with the law the contingency of the law itself. The passing beyond the concept of a thing to possible experience (which takes place $a$ priori and constitutes the objective reality of the concept) he confounded with the synthesis of the objects of actual experience, which is always empirical. He thus confounds a principle of affinity, which has its seat in the understanding and affirms necessary connection, with a rule of

of the soul with the same conclusiveness as any mathematical proposition - though both lie entirely outside the limits of possible experience." (Ibid., A854/B882- A855/B883).

${ }^{69}$ Ibid., B127.

${ }^{70}$ Barry Stroud, Hume, (London: Routledge, 1991), p. 87. 
association, which exists only in the imitative faculty of imagination, and which can exhibit only contingent, not objective, connections. ${ }^{71}$

Hume's empiricism, in Kant's view, thus threatens to collapse into an unmitigated scepticism. ${ }^{72}$ Hume, as Susan Neiman points out, had conflated the two aspects of Leibniz's principle of sufficient reason by conflating the idea that the world is subject to order with the capability of human Reason to discover that order. According to Kant, Hume's strict empiricism conflates the justification of the concept of causality with the discovery of actual empirical laws. ${ }^{73}$ Hume suggests that the objective applicability of the concept of causality is not justified unless we can observe actual empirical laws directly. Kant attempts to overcome the scepticism that he attributes to Hume by separating the two aspects of the principle of sufficient reason. He separates the claim that the empirical world is subject to order from the claim that human Reason is capable of discovering that order. In so doing, Kant thinks he can uphold the claim, contra Hume, that the objective applicability of the concept of causality is rationally justified independently of whether we are able to discover particular causal laws in experience. From this it seems that "[--] Kant's proof that the concept of causality is constitutive of experience does not require the guarantee of the existence of any empirical laws." ${ }^{74}$ Kant's distinction between the two aspects of the principle of sufficient reason indicates that the categories are only the conditions

\footnotetext{
${ }^{71}$ Kant, CPR, A766/B794-A767/B795.

${ }^{72}$ Hume's copy theory claimed that an "idea" is a less vivacious copy of an original sense-impression. In keeping with this strict empiricism he argued that the "idea" of causality must, if it is to be valid, have its origin in such a sense-impression. However, Hume contends that we can never have a direct impression of causality. He thus argued that it is somehow indirect in the sense of a feeling of determination that accompanies our experience of the constant conjunction of two particular events. (See Stroud, Hume, pp. 85-6).

${ }_{33}$ Hume, in Kant's view, is guilty of trying to make our knowledge conform to the object. Kant's epistemic turn, however, stipulates that the object must conform to our knowledge.
} 
of the possibility of experience in general. By this we mean that the categories are epistemically constitutive but that they do not, as Buchdahl points out, yield empirical law-likeness. They do not, in other words, say anything about the empirical content of experience. This can be seen clearly from the following citation from Kant:

Nature, considered merely as nature in general [Überhaupt] is dependent upon these categories as the original ground of its necessary conformity to law [natur formaliter spectata]. Pure understanding is not, however, in a position, through mere categories, to prescribe to appearances any $a$ priori laws other than those which are involved in a nature in general, that is, in the conformity to law of all appearances in space and time [---] To obtain any knowledge whatsoever of these special laws, we must resort to experience $[---]^{75}$

The above citation suggests that Kant addresses the difficulty regarding the rational justification of the objective applicability of the concept of causality at the constitutive level whilst dealing with the discovery of actual empirical laws at the regulative level. He argues that the concept of causality is theoretically justified to the extent that the categories of the Understanding can be shown to be a priori transcendental conditions of the possibility of knowledge. Thus Kant maintains that the concept of a "nature in general" requires the concept of causality. However, the discovery of actual empirical laws is, for Kant, a regulative research project whereby we seek systematic causal unity in experience rather than abstract such unity from experience. $^{76}$

\footnotetext{
${ }^{74}$ Susan Neiman, The Unity of Reason, (New York: Oxford University Press, 1994), p. 53.

${ }^{73}$ Kant, CPR, B 165.

${ }^{76}$ There are indications, however, that Kant sometimes conflates the distinction between constitutive and regulative. This is suggested in Buchdahl's examination of Kant's treatment of the relation between law-likeness and regulative ideas. [Gerd Buchdahl, Metaphysics and the Philosophy of Science, (Oxford: Basil Blackwell, 1969)]. Buchdahl articulates Kant's distinction between constitutive and regulative in the context of the issue of necessity as follows:

[---] although necessity as a categorial element determines the possibility of experience in general, it still does not yield the necessity of particular laws, which is a necessity not connected with their being empirical statements. Therefore, only as an analogy which parallels
} 
Kant's claim that the concept of causality is constitutive of the concept of a nature in general, but regulative with regard to the discovery of actual empirical laws pertains to the problem surrounding the relation of the categories to empirical intuition mentioned earlier. I suggested that, for Kant, the categories are constitutive with regard to non-empirical content but regulative with respect to empirical content. This implies that the constitutive role of the categories is devoid of a realist constraint. As such, the categories define the concept of a nature in general but they are unable to say anything about the actual content of that nature. To the extent that he construes the discovery of actual empirical laws as a regulative procedure, Kant suggests that our claims about the actual content of experience have a practical rather than theoretical justification. He maintains that, although Reason cannot furnish us with determinate theoretical knowledge, it can justify, in a practical sense, our belief in the systematic unity of nature. ${ }^{77}$ In so doing, he distinguishes between theory and practice arguing that praxis fills in the gaps of theory. ${ }^{78}$

the categorial case, should we regard necessity as 'injected' into the scientific situation, to yield its specific character of systematic order, with all those 'regulative' aspects (e.g. the regulative maxims) which this notion entails. (Buchdahl, pp. 517-8).

Here Buchdahl claims that Kant distinguishes between the constitutive role of the Understanding, whose concepts determine the possibility of experience in general, and the regulative role of Reason, which indirectly injects necessity into particular laws (specifically by seeking necessity in particular laws). However, Buchdahl points out that sometimes Kant conflates the constitutive with the regulative by suggesting that without the regulative idea of 'system' we cannot posit 'law-likeness' at all, and moreover, that without "the regulative systematic activity of reason, the whole concept [of causal necessity] could not arise in the first place." (Buchdahl p. 518). Buchdahl cites Critique of Judgement, 16, as an example of Kant's conflation of constitutive and regulative:

These laws, as empirical, may be contingent from the point of view of our understanding and yet, if they are to be called laws (as the concept of nature requires), they must be regarded as necessary in virtue of a principle of the unity of the manifold though it be unknown to us.

[In this context the unity of the manifold refers to the system of empirical laws rather than to the manifold of perceptions of the Transcendental Deduction. (see Buchdahl p. 518n2)].

77 The regulative character of the discovery of empirical laws can be seen from the Critique of Judgement where Kant claims that the supposition of the systematic unity of empirical laws is contingent. He indicates that the diversity of individual empirical laws may in fact be devoid of any systematic unity: 
Although Nietzsche praises Kant's response to Hume it would seem that he still considers Kant's solution to be deficient. The reason for this, I suggest, is rooted in Nietzsche's view that Kant's response to Hume results in a spurious distinction between theoretical "knowledge" and practically useful "belief" ${ }^{79}$ Moreover, Nietzsche argues that the non-cognitive status of such practically warranted beliefs is a ploy to facilitate Kant's desire to retain the old rationalist ideals. He maintains that Kant reaches the point of distinguishing between theoretical knowledge and practically useful belief by default:

The intellect disputes its right to make interpretations of this sort as well as to reject interpretations of this sort. One contents oneself with an increase in one's trust and faith, with a renunciation of all provability in matters of faith, with an inconceivable and superior "ideal" (God) as a stopgap. ${ }^{80}$

According to Nietzsche, Kant's distinction between "knowledge" and "faith" exacerbates the scepticism initiated by the constitutive account of knowledge and its lack of a realist constraint. For it can arguably be claimed that the distinction between theoretical knowledge and practically useful belief does nothing to resolve the problem of the separation of form and content. Kant's distinction between theoretical knowledge and practically justified belief entails that, where there is "knowledge"

But besides this formal time-condition, the objects of empirical cognition are determined, or, so far as we can judge a priori, are determinable, in divers ways, so that specifically differentiated natures, over and above what they have in common as things of nature in general, are further capable of being causes in an infinite variety of ways; [----] In respect of these we estimate the unity of nature according to empirical laws, and the possibility of the unity of experience, as system according to empirical laws, to be contingent. [Kant, Critique of Judgement, translated by James Creed Meredith, (Oxford: Clarendon Press, 1991), pp. 22-3].

${ }^{78}$ See Nicholas Rescher, Kant and the Reach of Reason, p. 89. Kant states:

[---] it is only from a practical point of view that the theoretically insufficient holding of a thing to be true can be termed believing. (Kant, CPR, A823/B851).

${ }^{79}$ Nietzsche, WP, 458 (1888).

${ }^{80}$ Ibid., 253 (1885-1886). 
(constitutive) there is no content, and where there is "content" (regulative) there is no knowledge. Thus, according to Nietzsche, Kant's constitutive account of knowledge is devoid of a realist constraint whilst his regulative account of belief is deprived of epistemic value. The regulative idea's lack of epistemic value is particularly problematic in the context of the failure of Kant's constitutive account of knowing to allow for the reconciliation of knowledge and metaphysics. However, in what follows, I will suggest that Nietzsche thinks that this difficulty can be remedied by abandoning the constitutive account in favour of a regulative and pragmatic conception of knowledge that reinstates a cognitive relationship between self and world. It now remains for me to examine the manner in which Nietzsche reworks the Kantian programme. It is to this that I now turn.

\subsection{Nietzsche's Reworking of Kant}

In this section I will examine Nietzsche's estimation of the failure of Kant's constitutive/regulative distinction to close the epistemic gap between self and world. In so doing, I will investigate the manner in which Nietzsche's response to this failure allows for a realist constraint to our knowledge that he thinks is absent from Kant's account. This will involve an examination of Nietzsche's overcoming of the separation of theory and practice that he detects Kant. Finally, I will indicate the regulative direction that Nietzsche's thought takes once this separation has been overcome. I will begin, however, by briefly recapitulating Nietzsche's appraisal of Kant. 
We have witnessed Nietzsche's view that there are three interrelated problems pertaining to Kant's attempt to reconcile knowledge and metaphysics. The first is the separation of form and content. The second problem centers round that of the thingin-itself, whilst the third pertains to Kant's desire to reinstate the old rationalist ideals of God and morality. All three problems, we have seen, are reducible to the distinction between constitutive knowledge and regulative belief. Moreover, we have considered Nietzsche's view that both Kant's constitutive account of knowledge and regulative appeal to practically warranted beliefs fail to reconcile knowledge and metaphysics. ${ }^{81}$ The constitutive account of knowledge, according to Nietzsche, lacks a realist constraint due to its emphasis on a priori form and its consequent elimination of the epistemic role of content. The maxims of Reason were designed by Kant to address the issue of content by assigning a significant, regulative, role to principles of empirical research. However, due to the cognitively indeterminate status of the regulative ideas, the maxims of Reason are powerless to close the epistemic gap. Indeed Kant seems to recognize this when he states:

\footnotetext{
${ }^{81}$ There are some suggestions in the Kantian texts that the thing-in-itself is an indeterminate concept that plays the role of a regulative idea. This is most suggested when we understand that the thing-initself is an object of thought rather than an object of knowledge. This further suggests that the concept of the thing-in-itself belongs to the province of Reason rather than to the constitutive sphere of the Understanding. If this is the case, then, it seems that the thing-in-itself acts as a regulative form of realism. We must proceed, according to Kant, "as if" our appearances were appearances of an external and objective metaphysical object. However, even as a regulative idea the role of the thing-in-itself is unable to provide us with a realist constraint because, as has been suggested in the main text, Kant's regulative principles are no more able to access empirical content than can the categories of the Understanding. One of the reasons for this is that the regulative ideas of Reason have as their subject matter the concepts of the Understanding. We have already seen that the relationship between the Understanding and content is tenuous and in fact that Kant regulativizes the non-mathematical categories with respect to intuition. If the relationship between the Understanding and empirical content is weak in this sense then it is difficult to see how the regulative ideas of Reason, which are regulative with respect to both intuition and experience in general, can get any closer to content. Kant, therefore, seems to be confronted with an irreconcilable gap between the concept and its content or between subjects and their cognitive relation to how things are in themselves.
} 
This gap in our knowledge can never be filled; all that can be done is to indicate it through the ascription of outer appearances to that transcendental object which is the cause of this species of representations, but of which we can have no knowledge whatsoever and of which we shall never acquire any concept. ${ }^{82}$

Nietzsche's criticisms of Kant's distinction between the theoretical and the practical further hint at his dissatisfaction with the particular role that Kant assigns to regulative ideas. Since Nietzsche does not give us any clear indication of the specific reasons informing his dissatisfaction, we must hypothesize as to its roots. One bone of contention that Nietzsche would seem to have pertains to the a priori and transcendental status of the regulative principles. This suggests to Nietzsche that the regulative principles, although heuristic tools of research that are necessary to get scientific investigation off the ground, are unchangeable and fixed. This can be discerned from the fact that when Nietzsche outlines Kant's view he does not make a sharp distinction between Understanding and Reason. ${ }^{83}$ Thus it would seem that, for Nietzsche, Kant's regulative principles are not regulative enough. What I am suggesting here is that Kant, according to Nietzsche, theoreticized the practical. We will see that Nietzsche considers his own project a more successful one because he seeks to practicalize theory. A regulative principle for Nietzsche is something that is open to the possibility of change as our interaction with the world changes. It is his view that the a priori status of Kant's principles of research precludes any such development. Nietzsche suggests that Kant should give a genealogical account of both the categories and a priori regulative principles rather than the logical account

\footnotetext{
${ }^{82}$ Kant, CPR, A393.

${ }^{83}$ See Nietzsche, WP, $530(1883-1888)$ where he refers to the categories as the a priori activity of pure Reason.
} 
proffered in the Critique. Genealogical investigation reveals, Nietzsche claims, that our "practical needs" 84 and interests guide our investigation of the world:

In the formation of reason, logic, the categories, it was need that was authoritative: the need, not to "know," but to subsume, to schematize, for the purpose of intelligibility and calculation - (The development of reason is adjustment, invention, with the aim of making similar, equal the same process that every sense impression goes through!) No pre-existing "idea" was here at work, but the utilitarian fact that only when we see things coarsely and made equal do they become calculable and useful to us--- ${ }^{85}$

In the light of his view that such practical interests direct our cognitive engagement with the world, Nietzsche urges that the distinction between theory and practice be brought to an end. He writes:

Dangerous distinction between "theoretical" and "practical", e.g., in the case of Kant but also in the case of the ancients: they act as if pure spirituality presented them with the problems of knowledge and metaphysics; they act as if practice must be judged by its own measure, whatever the answer of theory may be. ${ }^{86}$

Nietzsche thus takes as his aim "Not to live with two different standards! - not to separate theory and practice". 87

We have seen that Nietzsche suggests that Kant's constitutive principles should be construed as regulative articles of belief. This implies that Nietzsche has some regard for regulative principles in contrast to his rejection of constitutive ones. His warning against the practice of adopting two different standards suggests that Nietzsche abandons Kant's constitutive conception of knowledge in favour of a purely regulative conception. ${ }^{88}$ Thus he claims that the Kantian problematic should

\footnotetext{
84 Ibid., 515 (1888).

85 Ibid.

${ }^{86}$ Ibid., 458 (1888).

${ }^{87}$ Ibid.

${ }^{88}$ That Nietzsche endorses regulative principles of research is noted by Keith Ansell-Pearson when he cites Nietzsche as follows:
} 
be rephrased from asking "how are synthetic a priori judgements possible?" to "why is the belief in such judgements necessary?"89 This also explains Nietzsche's claim in Beyond Good and Evil that the concepts of cause and effect should be regarded as useful fictions. ${ }^{90}$ This claim is often read as committing Nietzsche to some form of Humean scepticism. However, in this context we can see that a more fruitful reading of his point can be given if we consider that what Nietzsche is actually saying here is that the concepts of cause and effect should be taken as regulative ideas that guide our investigation of the world. This is also implied in his suggestion that we should employ the concept of causality as the best explanation of an event. ${ }^{91}$ His regulativization of the Kantian programme serves a number of purposes. Most

A philosophy not as dogma, but as a provisional regulative of research (vorlaufige Regulative der Forschung). (KSA 11, 26 [432], p. 266. Cited by Ansell-Pearson, "Nietzsche's Brave New World of Force" in Pli: The Warwick Journal of Philosophy, 9, 2000, p. 25).

${ }^{89}$ Nietzsche, BGE, 11.

${ }^{90}$ Ibid., 21.

${ }^{91}$ Nietzsche, Twilight, VI.4 and VI.5. Nietzsche argues that most of our general feelings invalidly stimulate the causal drive. He states that "we want a reason for having such and such a feeling [--] We are never satisfied with simply establishing the fact that we have such and such a feeling: we license this fact - become conscious of it - only when we have given it a kind of motivation." (VI.4). Some commentators have read these passages as an indication of Nietzsche's "Humean" account of causality, arguing that, for Nietzsche, the very concept of causality is a fiction. However, closer examination of these passages suggests that Nietzsche endorses the regulative employment of the concept of causality. What Nietzsche wams against in the passages in question is the practice of appealing to cause on the basis of memory. Nietzsche argues that we often attribute the same cause to a particular effect on the basis of memory. This, he suggests, hinders regulative research in that it "inhibits any inquiry into causes and even rules it out." (VI.4). My regulative reading indicates that Nietzsche endorses the practice of seeking out explanations for events but that he rejects "the most usual explanations" (VI.5).

However, it may still be argued that Nietzsche rejects the idea of employing the concepts of cause and effect as explanations. For example, in BGE, 21 he states:

[---] 'cause' and 'effect' should be used only as pure concepts, as conventional fictions for the purpose of description or communication, and not for explanation.

However, it should be noted that Nietzsche denies the explanatory power of the mechanical atomist's push and pull idea of cause and effect here and not the explanatory power of the concept of causality per se. He states:

One should not make the mistake of concretizing 'cause' and 'effect' as do the natural scientists [--] in conformity with the prevalent mechanistic foolishness that pushes and tugs at the cause until it 'has an effect'. (BGE, 21).

Nietzsche's endorsement of the notion of explanation will be explored in more detail in Chapter Four, Part Two, where I will take up the issue of his appropriation of Boscovich's concept of force. 
importantly, by assimilating the theoretical to the practical Nietzsche regulativizes Kant's constitutive principles of the Understanding. In so doing, Nietzsche eliminates the view that we constitute the world. Furthermore this has the repercussion that he also eliminates the epistemic object, which was, for Kant, the result of synthesis. In so eliminating Kant's epistemic object Nietzsche removes the distinction between things-in-themselves and appearances. According to Nietzsche, Kant's account of appearance places a mediation between knowers and the thing-in-itself. This mediation, however, lends itself to scepticism in Nietzsche's eyes because the thingin-itself does not feature in our appearances. By assimilating the theoretical to the practical and thus eliminating Kant's constitutive conception of the object Nietzsche removes this mediating factor and restores reality back to its rightful status as the object of knowledge. In so denying us any constitutive role Nietzsche attempts to realign the metaphysical and the epistemological object. In such a way what we are left with is one metaphysical object, reality, with which we engage in an interestfocused manner. It is in this context that we can best understand Nietzsche's ambiguous claim that our truths are errors. Such passages are often read as committing Nietzsche to some form of sceptical idealism with regard to human knowledge. The sceptical idealist interpretation argues that we are caught within a strict anthropomorphic conception of knowledge that is not in touch with the real in any way. It claims that our human knowledge is perpetually vulnerable to the charge of radically falsifying reality. However, if we read Nietzsche's claim that our truths are errors in the light of his commitment to a regulative conception of knowledge rather than a constitutive one, then we can see that he is making a more interesting 
philosophical point. This point stresses the non-constitutive nature of our knowledge and thus the genuine independence of the world that is the object of both metaphysical and epistemological inquiry. Consider the following passage from Human, All Too Human, 19:

Whenever we establish something scientifically, we are inevitably always reckoning with some incorrect quantities; but because these quantities are at least constant (as is, for example, our feeling of time and space), the results of science do acquire a perfect strictness and certainty in their relationship to each other. One can continue to build upon them - up to that final analysis, where the mistaken basic assumptions, those constant errors, come into contradiction with the results [my emphasis], for example, in atomic theory. [----] To a world that is not our idea, the laws of numbers are completely inapplicable: they are valid only in the human world. ${ }^{92}$

In this passage Nietzsche can be seen to play with the notion of an "idea". In opposition to Berkeley he maintains that the idea cannot be identified with reality. We may be acquainted with ideas but such ideas are "errors" in the sense that they are merely regulative. Their regulative character can be inferred from Nietzsche's emphasis on the results of scientific inquiry. Should the regulative ideas come into conflict with the results of empirical investigation they may have to be abandoned. Here Nietzsche introduces an epistemic role for content - a realist constraint - that he thinks is missing in Kant. However, it may be objected that Nietzsche, in reinstating the metaphysical object as the focus of epistemological inquiry, merely undoes the good work that Kant had established. In other words, it may be argued that Nietzsche merely reintroduces the problem, with which Berkeley confronted Locke, that is, how to explain that the "idea" conforms to the object if it is distinct from that object. However, Nietzsche's position arguably does not collapse back into this dichotomy because his ideas, unlike those of Berkeley and Locke, are not first order ideas.

92 Nietzsche, HAH, 19. 
Rather, they are regulative principles of research that guide our investigation of nature. As such, Nietzschean ideas are second-order methodological tools. In this way Nietzsche in fact makes good Kant's epistemic turn that prioritizes epistemology over metaphysics. The problem with the Kantian project for Nietzsche, however, was that Kant's constitutive conception of epistemology lacked a realist constraint. Thus, according to Nietzsche, Kant dissociated human knowledge and reality. Nietzsche thinks that his reworking of the Kantian paradigm has remedied this problem. But it is important that we recognize that Nietzsche's regulative ideas of research are not just methodological tools. They are also indicators of our interest-directed engagement with the world. Thus he retains, in one sense, an anthropomorphic conception of knowledge. However, unlike Kant as interpreted by Nietzsche, this does not entail that our human knowledge is inadequate to reality. The reading of Nietzsche that I am proposing here commits him to the view that our anthropomorphic truths are capable of objective status to the extent that they do adequately capture the world in some, albeit selective, way. This can be illustrated by briefly contrasting the status of human knowledge in both Kant and Nietzsche.

According to Kant the object of knowledge is composed of the a priori and the Given. The Given is the intuitional component of a representation that affects Sensibility. However, Kant emphasizes that our mode of intuiting objects is restricted to the human. He thus entertains the possibility that there are other modes of intuition than the human. Intellectual intuition, for example, is not, according to Kant, restricted by Sensibility and so the mode of intuiting and intellecting objects is said to 
be one and the same. With intellectual intuition perceiving and creating are synonymous. For a being capable of intellectual intuition, then, the division between the actual and the possible is surrendered. The possibility of such a mode of intuition demonstrates, what A.W. Moore terms, the "inherent perspectival" character of the Kantian account of knowledge. Moore argues that the problem with inherent perspectivalism is that it disallows the possibility of "objective" representations. ${ }^{93}$ Objective representations are necessary, according to Moore, if one is to maintain a realist position because realism entails the idea of adequate knowledge and the view that reality is what representations answer to. However, it is important to realize that the notion of adequate knowledge entertained by Moore here does not entail the view that adequacy consists in unmediated confrontations with the world, but rather, that adequacy consists in correctness, which, in turn, comprises justification. This view claims that reality is what our representations answer to, but it is not what makes our representations correct. According to Moore, the notion of inherent perspectivalness disallows a realist constraint by entertaining the possibility of other points of view incommensurate with our own. ${ }^{94}$ The inherent perspectival character of human knowing is suggested in Kant's account of intuition:

\footnotetext{
93 A. W. Moore, Points of View, (Oxford: Clarendon, 1997), p. 123. Moore actually uses the term "absolute" rather than "objective". I prefer to use the term "objective", as it is more in keeping with Nietzsche's epistemological concerns regarding the reconciliation of knowledge and metaphysics. In GM, III, 12, for example, Nietzsche addresses the "objectivity" of human knowledge. However, this replacement does not alter the significance of Moore's argument within the context of the present analysis.

94 Ibid.
} 
It is therefore, solely from the human standpoint that we can speak of space, of extended things, etc. If we depart from the subjective condition under which alone we can have outer intuition, namely, liability to be affected by objects, the representation of space stands for nothing whatsoever. ${ }^{95}$

Since our mode of intuiting objects is restricted to the human standpoint in this way,

Kant maintains that

[---] we cannot judge in regard to the intuitions of other thinking beings, whether they are bound by the same conditions as those which limit our intuition and which for us are universally valid. ${ }^{96}$

The difficulty is exacerbated by Kant's reference to the thing-in-itself as an absolute outside viewpoint that is unavailable to our human sensible mode of intuition:

What we have meant to say is that all our intuition is nothing but the representation of appearance; that the things which we intuit are not in themselves what we intuit them as being, nor their relations----We know nothing but our mode of perceiving them [---]. ${ }^{97}$

It may be argued that the application of the a priori categories injects objectivity into intuitions and thus removes the inherent perspectival character of the Kantian representation that Moore detects. However, such a response is unsatisfactory to Nietzsche because he thinks that Kant has not justified his constitutive employment of the categories. Nietzsche argues that philosophers have viewed concepts as if they were a dowry from some kind of wonderland. ${ }^{98}$ This objection gains added strength from Kant's silence regarding the necessity of us possessing the particular categories that we do:

This peculiarity of our understanding, that it can produce $a$ priori unity of apperception solely by means of the categories, and only by such and so many, is as little capable of further

\footnotetext{
95 Kant, CPR, A26/B42-B43.

96 Ibid., A27.

97 Ibid., A42/B59.

98 Nietzsche, WP, 409 (1885). See also BGE, 11 where Nietzsche argues that Kant is unable to "explain" why we possess the specific categories that he attributes to human knowing.
} 
explanation as why we have just these and no other functions of judgment, or why space and time are the only forms of our possible intuition. ${ }^{99}$

The suggestion that Kant is guilty of inherent perspectivalness commits him to, what Moore terms, the Specious View. This view is articulated as the "temptation to align content with type". ${ }^{100}$ It claims that "what makes a true representation true depends solely on what type of representation it is." ${ }^{101}$ Thus the Specious view maintains that perspectival facts obtain only relative to a point of view. This suggests that perspectival facts and perspectives are identical. It proposes that perspectival facts "are unlike other facts in that their obtaining is itself relative to a point of view. The perspectival facts that obtain from one point of view are different from those that obtain from another." ${ }^{102}$ Nietzsche, in claiming that Kant's categories should be given a regulative rather than a constitutive status, distinguishes between perspectives and facts. In so doing, he adopts a position similar to Moore who claims, in opposition to the Specious View, that

\footnotetext{
'Absolute' and 'perspectival' simply do not apply to facts. They apply at the level of what represents, not at the level of what is represented. ${ }^{103}$
}

However, there is a neo-Kantian line of interpretation in the Nietzsche literature that argues, mistakenly in my estimation, that Nietzsche is committed to something like the Specious View. This interpretation argues that Nietzsche's

\footnotetext{
99 Kant, CPR, B145-6.

${ }^{100}$ Moore, Points of View, p. 47.

${ }^{101}$ Ibid.

${ }^{102}$ Ibid., p. 42.
}

${ }^{103}$ Ibid., p. 45. In WP, 481 (1883-1888) Nietzsche denies that there are facts, claiming that there are only interpretations. However, this statement does not conflict with my argument above. For I take Nietzsche's denial of facts in WP, 481 to mean that we cannot appeal to self-justifying beliefs (facts) to justify a proposition. This claim does not, however, entail a denial of the realist view that some interpretations are more adequate than others. It is this latter idea of epistemic superiority that I want to 
employment of the notion of Becoming commits him to the Kantian conception of a realm or level of reality that is radically different from our beliefs about it. Proponents of this view argue that, for Nietzsche, reality as it is in itself, that is, as it is independently of our cognitive distortions and simplifications, is in radical flux. According to this view, our cognitive practices simplify the flux in a way that arbitrarily stabilizes it. Thus this interpretation posits an epistemic gulf between our knowledge and the character of reality itself. In so doing, it commits Nietzsche to the very Kantian dualism that he wishes to avoid. This difficulty can be removed however, if we interpret Nietzsche's views on Becoming as applying to our cognitive apparatus also. By this I mean that Nietzsche's doctrine of Becoming is both an epistemic and a metaphysical thesis. This alternative interpretation proposes that Nietzsche's conception of Becoming applies to both our manner of knowing the world and the character of the world. ${ }^{104}$ Nietzsche suggests that the knowing self is immersed in the process of Becoming and consequently that our knowledge does not stand over and against this process. He thereby removes the epistemic gap that was opened up by Kant's distinction between constitutive knowledge and regulative belief. Cox captures the spirit of such a view in the following:

\begin{abstract}
Nietzsche's contention that such strictures are "false" is not a claim that something else - for instance, the world of becoming - is true. Here, as elsewhere, he makes polemical use of the terms "true" and "false," reversing the assignments given to them within the old schema that he is attempting to dismantle. Contrary to the metaphysicians, he argues, such edifices do not grant us "the truth" conceived of as the total comprehension of a stable world of being. In this sense, then, they are "false". But that is because such "truth" is not forthcoming, and such "falsity"- such provisional and pragmatic horizons [my emphasis] - is all we ever have, "for there is no "truth." Nietzsche's aim here is to show that, contrary to the metaphysical view,
\end{abstract}

attribute to Nietzsche. In so doing, I am attributing to him the view that we cannot appeal to the nature of reality to justify a claim but that the justification of a claim entails its adequacy to reality.

${ }^{104}$ This theme will be discussed in greater detail in Chapter Four. 
our conceptual and linguistic edifices ought not to be set over and against becoming and do not provide us with a glimpse of another "true world." Rather, they themselves are a part of becoming: that is, they are themselves instances of the construction and inhabitation of provisional, conditional, and contingent horizons that satisfy important needs and desires. ${ }^{105}$

To support this interpretation Cox glosses some of those passages that are often cited in defense of the claim that Nietzsche posits a realm of becoming that is incommensurable with the realm of human knowing. I will cite one of these passages along with Cox's gloss in parenthesis:

The character of the world of becoming as unformulable, as "false," as "self-contradictory." [We can never stabilize and totalize from without a world that is in constant transition and of which we ourselves are a part.] Knowledge and Becoming exclude one another. [Conceived as the totalizing comprehension of a world of being, knowledge will be confounded by the world of becoming in which we live.] Consequently, "knowledge" must be something else: there must first of all be a will to make knowable, a kind of becoming must itself create the deception of beings. [If we want to maintain some notion of knowledge, we must conceive it differently. Instead of setting it over and against "becoming," we should see it as itself "a kind of becoming," as a process within becoming - as an active interpretation rather than a passive mirroring, as the will of living beings to select from, simplify, and stabilize their world so as to insure their self-preservation and/or -enhancement. Such a simplification and stabilization constitutes a "deception" insofar as it is not uniquely correct, for there are other purposes toward the satisfaction of which one might construe the world differently; and there is no construal that conjoins all purposes. $]^{106}$

By considering human knowledge as a "process within becoming" Nietzsche suggests that the knowing self is not divorced from reality. It is in this context that we can best understand Nietzsche's claim that psychology is the queen of the sciences and the path to the resolution of fundamental problems. ${ }^{107}$ By these claims I take Nietzsche to mean that we can only answer the question of what is the real by first

${ }^{105}$ Christoph Cox, Nietzsche: Naturalism and Interpretation, (London: University of California Press, 1999), p. 145.

${ }^{106}$ Ibid., p. 145-6, Nietzsche WP, 517 (1887). I agree with Cox's suggestion that Nietzsche's claim that knowledge is a "deception" entails that there is no "uniquely correct" description of the world. However, Cox takes this to mean that no interpretation is more correct than any other. In contrast, I understand the view that there is no uniquely correct description to mean that no thesis is unrevisable. This does not entail, as Cox suggests, a rejection of the idea that some interpretations are epistemically superior to others. I address this particular aspect of Cox's view in more detail in Chapter Four, Part One (section 4.5).

107 Nietzsche, BGE, 23. 
asking who we are. ${ }^{108}$ In this way Nietzsche heeds Kant's warning that we are led to scepticism if we construe our knowledge as conforming to the object rather than the object as conforming to our knowledge. In so doing, Nietzsche avoids the charge of reinstating the difficulty of explaining how the world makes itself known to us by shifting the epistemic focus from the object to the human knower and our practices of justification. However, he modifies Kant's response by examining the object through the lens of our interest-directed mode of knowing. In so doing, he immerses our knowledge within the world to the extent that the knowing subject itself becomes an evolving part of the world. The question of what constitutes knowledge, according to Nietzsche, has only provisional answers adopted from within our immersion in a larger evolving whole. It is precisely this regulative standpoint that enables Nietzsche to overcome the scepticism that he attributes to Kant and the view that claims that our anthropomorphic empirical truths are divorced from the nature of reality.

In the remainder of this thesis I will set about demonstrating the manner in which Nietzsche makes good his regulative project. In chapter two this will involve an examination of Nietzsche's perspectivism in the particular context of his rejection

108 This results in a view whereby the relation between self and world is construed as one between evolving part and evolving whole. Nietzsche describes this relationship in an early note when he says:

Now man has evolved slowly, and knowledge is still evolving: his picture of the world thus becomes ever more true and complete. Naturally it is only a clearer and clearer mirroring. But the mirror itself is nothing entirely foreign and apart from the nature of things. On the contrary, it too slowly arose as [part of] the nature of things. We observe an effort to make the mirror more and more adequate. The natural process is carried on by science. Thus the things mirror themselves ever more clearly, gradually liberating themselves from what is all too anthropomorphic.

[Friedrich Nietzsche, "The Philosopher", paragraph 102 in Philosophy and Truth: Selections from Nietzsche's Notebooks of the Early 1870's, edited and translated by Daniel Breazeale, (London: Humanities Press, 1993)]. 
of the thing-in-itself and what he sees as the metaphysical realist dissociation of truth and justification. It is to this that I now turn. 


\section{Chapter Two}

\section{Nietzsche's Perspectival Theory of Knowledge}

\subsection{Introduction}

In chapter one I examined Nietzsche's evaluation of Kant's epistemology. There we witnessed that both Kant's constitutive account of knowledge and regulative account of belief, as interpreted by Nietzsche, results in the very sceptical idealism that Kant wants to avoid. Furthermore, I indicated that Nietzsche thinks that this difficulty can be resolved by rejecting Kant's constitutive epistemology in favour of a regulative and interest-directed conception of knowledge. In so doing, we saw that Nietzsche considers knowledge to be anthropomorphic but realist in character. Here in chapter two I will return to the theme of interest-directed knowledge in the context of Nietzsche's perspectivism as a rejection of metaphysical realism. Metaphysical realism is the term that I will now use to denote the general view that Nietzsche attributes to Kant. In particular, this view captures the problem of the thing-in-itself that Nietzsche claims is a thom in Kant's philosophy. Nietzsche's concern with this issue centers round Kant's contention that the thing-in-itself is unknowable to beings with our specifically human cognitive constitution and with overcoming the epistemic gap that is opened up between self and world. In keeping with the overall aim of the thesis, my investigation in this chapter will be issue directed. My examination will focus, then, on issues that can, in Nietzsche's view, be broadly described as Kantian in character. I will thus examine the issues of scepticism and the relationship between truth and justification in the context of Nietzsche's attempt to establish an anti-metaphysical realist framework. 
My investigation will be divided into five further sections. The first of these will set up the problem of metaphysical realism and will outline the requirements that Nietzsche must meet if he is to overcome it. The following two sections will address the extent to which Nietzsche satisfies these requirements through an examination of both his perspectivism and empiricism. By examining the issues of perspectivism and empiricism we will witness Nietzsche's positive response to the Kantian FormContent problem that was outlined in chapter one. There we saw that Kant arguably diminishes the role of empirical content to the extent that all constraints are subjective and formal rather than realist in character. By demonstrating that it is possible to retain a realist constraint without lapsing into either empiricist dogmatism (where the constraint is one-sidedly empirical) or rationalist dogmatism (where the constraint is one-sidedly formal), I will argue that Nietzsche can successfully respond to and overcome the scepticism that he regards as Kant's legacy. The penultimate discussion of these issues will then turn to an analysis of the opposing idealist and realist readings of Nietzsche's anti-metaphysical realist stance. Finally, I will embark upon a textual examination in order to draw out Nietzsche's anti-metaphysical realist position, which, I will argue, replaces metaphysical realism with a perspectivist internal realism. In so doing, my principal concern in this chapter is to demonstrate that Nietzsche's perspectivism provides an arena from which it can justifiably be claimed that our anthropomorphic truths are subject to a realist constraint.

Before we proceed, however, it is to be noted that a shift in terminological usage takes place in this chapter. In chapter one I employed the terms "theoretical" and "practical" in relation to Kant's distinction between constitutive knowledge and 
regulative belief. However, in taking up the problem of the thing-in-itself specifically in this chapter we will see that Nietzsche holds the view that Kant adopts a two tiered theory of truth. On one level Kant is said to maintain that "truth" corresponds to those "objects" of empirical knowledge that we as knowers constitute. In chapter one this was referred to as theoretical constitutive knowledge. However, on another level as we shall soon see, Nietzsche believes that Kant upholds the view that "truth" corresponds to the unattainable thing-in-itself. Such "truth" is also theoretical in character to the extent that it is upheld as an ideal that cannot be attained in practice. Considering this, then, it seems that Nietzsche's complaint that Kant separates theory and practice operates on these two levels. Since I have addressed the constitutive/regulative distinction in chapter one and shown how Nietzsche abandons the former and modifies the latter for his own purposes, I will focus on the second level understanding of the theory/practice divide. That is, in this chapter "theory" refers to that inaccessible "truth" represented by the unknowable thing-in-itself. In keeping with this usage, "practical" will refer to all our "anthropomorphic" truths. ${ }^{1}$ Since we have seen that Nietzsche thinks that all truths characterized by Kant as constitutive should be regulative beliefs anyway, I will ignore whether in Kant's eyes such anthropomorphic claims have constitutive or regulative status. With this clarification in mind I will begin by outlining Nietzsche's understanding of metaphysical realism.

\footnotetext{
1 These two leveis were alluded to in chapter one in my examination of Nietzsche's assessment of Kant's "negative" account of knowledge. (see section 1.2) There I argued that, according to Nietzsche, our beliefs must be denied epistemic merit if "knowledge" is equated with either Kant's constitutive account or with things-in-themselves.
} 


\subsection{Metaphysical Realism}

Nietzsche claims that our Kantian heritage has left us with a dualistic metaphysical system that adopts, what he terms, the will to truth as both a moral and epistemological imperative. Nietzsche construes the will to truth in this specific sense, as a desire for disinterested truth:

First mark of the self-preservative instinct of the great psychologist: he never seeks himself, he has no eyes for himself, no interest or curiosity in himself - The great egoism of our dominating will requires that we shut our eyes to ourselves - that we must seem to be 'impersonal,' 'désintéressé,' 'objective'!'

Moreover, Nietzsche claims that disinterested truth has been identified with extraempirical truth. In so doing, he argues that philosophy has operated within a hierarchical dualistic schema. According to this schema, the world is divided into two components, real and illusory, being and becoming, mind and senses. The dualism is hierarchical to the extent that it values atemporal, universal and unchanging categories more highly than those of time, particularity and change. This valuation, according to Nietzsche, denigrates the actual phenomenal world as an illusion whilst positing a supersensuous account of reality and truth. Bernd Magnus articulates this dichotomy in the following manner:

This schizoid habit of speech and thought does not merely result in double-vision but in hierarchical vision as well. For in each of the above couple an order of rank, an order of ontological dignity, is attached. Our philosophic predisposition is to prize and praise the universal, the timeless. We consecrate it by baptizing it "being" or "reality". Its domain is to be separated sharply (even if only conceptually) from the infection of what is particular, temporal, apparent. Being must be protected from becoming. ${ }^{3}$

Nietzsche contends that philosophers have operated within a dualistic appearance/reality dichotomy where reality is deemed to be an extra-empirical realm

\footnotetext{
${ }^{2}$ Friedrich Nietzsche, The Will to Power, translated by Walter Kaufmann and R. J. Hollingdale, (New York: Vintage Books, 1968), 426 (1888). Hereafter cited as WP.
} 
of truth whilst the actual empirical world of our ordinary experience is deemed to be a realm of deception and untruth. It is thus Nietzsche's contention that philosophy has operated within a metaphysical realist paradigm. Metaphysical realism is the view that "reality is something-in-itself, that its nature is determinately constituted independently of us [---]". It maintains that reality is epistemically divorced from cognitive subjects. Nietzsche writes:

[---] stricter logicians, after they had rigorously established the concept of the metaphysical as the concept of that which is unconditioned and consequently unconditioning, denied any connection between the unconditioned (the metaphysical world) and the world we are familiar with. So that the thing-in-itself does not appear in the world of appearances, [my italics], and any conclusion about the former on the basis of the latter must be rejected. ${ }^{\text {s }}$

As such, the metaphysical realist implies that our beliefs may be radically false. They may be false in the sense that they fail to mirror reality as it is independently of our cognitive constitution. According to Nietzsche, this metaphysical realist desire to mirror reality as it is in itself requires a conception of the cognitive subject as one unhindered by particular cognitive interests. Metaphysical realism thus adopts a God's Eye View or supra-perspectival standard of both truth and reality. Nietzsche's disagreement with the metaphysical realist involves, as it also does for Michael Williams, not "our trying to 'understand objective knowledge' but rather our trying to 'understand knowledge objectively,' i.e. from the 'detached,' philosophical perspective. ${ }^{.6}$ Nietzsche's disagreement centers round the epistemological thesis contained in metaphysical realism. This epistemological thesis maintains that our

\footnotetext{
${ }^{3}$ Bernd Magnus, Nietzsche 's Existential Imperative, (London: Indiana University Press, 1978), p. 21.

4 Maudemarie Clark, Nietzsche on Truth and Philosophy, (Cambridge: Cambridge University Press, 1990), p. 41.

${ }^{5}$ Friedrich Nietzsche, Human, All Too Human, translated by Marion Faber and Stephen Lehmann, (London: Penguin, 1994), 16. Hereafter cited as HAH.
} 
knowledge is only adequate to reality if that knowledge is extra-perspectival and therefore non-anthropomorphic in character. This epistemic thesis is articulated in metaphysical realism in two ways. For metaphysical realists can, in Nietzsche's view, be divided into two groups. ${ }^{7}$ We can characterize them as either cognitivists or anticognitivists with regard to the knowability of the metaphysical "real" world. The cognitivist claims that reality is both accessible and knowable whilst those metaphysical realists of the anti-cognitivist persuasion argue that reality as it is in itself is inaccessible. Rationalist metaphysicians represent the former. The latter view arrives on the philosophical scene, according to Nietzsche, in the guise of Kant. This anti-cognitivist form of metaphysical realism emerges following the demise of the cognitivist version. Thus in order to better understand Nietzsche's critique I will adumbrate both versions in turn.

Nietzsche argues that the aforementioned metaphysical realist practice of devaluing the empirical world has its roots in the rationalist appeal to a priori Reason as the source of knowledge of the "real" world. By this I mean that it is Nietzsche's view that rationalist metaphysics claim to have unmediated conceptual access to an extra-empirical realm of reality as it is in itself. Its concepts are presented as something innate and certain as opposed to Nietzsche's view that they have evolved over a period of time:

\footnotetext{
${ }^{6}$ Michael Williams, Unnatural Doubts: Epistemological Realism and the Basis of Scepticism, (Oxford: Blackwell, 1991), p. 254.

${ }^{7}$ What I call "metaphysical realism" here is the same as what Michael Williams calls "epistemic realism" in Unnatural Doubts. I follow Maudemarie Clark in using the term "metaphysical realism", however, because it captures Nietzsche's view that the epistemological issues of truth and justification have been intertwined with dualist metaphysics throughout the history of philosophy.
} 
Hitherto one has generally trusted one's concepts as if they were a wonderful dowry from some sort of wonderland: but they are, after all, the inheritance from our most remote, most foolish as well as most intelligent ancestors. ${ }^{8}$

However, of the cognitivist metaphysical realist model, Nietzsche claims that "Reality is nowhere to be found in them, not even as a problem." $\mathrm{He}$ argues that this particular interpretation of the world is "fabricated solely from psychological needs" 10 and that once this has been revealed through genealogical and historical inquiry, the dissolution of this metaphysical picture will be inevitable. ${ }^{11}$ Genealogy inquires into the contingent origins of a belief whilst historical inquiry traces the development of the belief. Nietzsche claims that once the psychological and moral ulterior guiding motives behind the invention of the metaphysical dualism are revealed, this dualism will be refuted:

Metaphysical world. It is true, there might be a metaphysical world; one can hardly dispute the absolute possibility of it. We see all things by means of our human head, and cannot chop it off, though it remains to wonder what would be left of the world if indeed it had been cut off. This is a purely scientific problem, and not very suited to cause men worry. But all that has produced metaphysical assumptions and made them valuable, horrible, pleasurable to men thus far is passion, error, and self-deception. The very worst methods of knowledge, not the very best, have taught us to believe in them. When one has disclosed these methods to be the foundation of all existing religions and metophysical systems, one has refuted them. [my italics $^{12}$

Metaphysical realism, in its cognitivist guise, becomes an untenable philosophical position, according to Nietzsche, once the will to truth undermines itself. It does this in the sense that it can no longer endorse the belief in the "true" world once genealogical and historical inquiry reveal its origins. Nietzsche writes:

But among the forces cultivated by morality was truthfulness: this eventually turned against morality, discovered its teleology, its partial perspective - and now the recognition of this

\footnotetext{
${ }^{8}$ Nietzsche, WP, 409 (1885). Cf. Twilight of the Idols, translated by Duncan Large, (Oxford: Oxford University Press, 1998), III.4. Hereafter cited as Twilight.

${ }^{9}$ Nietzsche, Twilight, III.3.

${ }^{10}$ Nietzsche, WP, 12A (1887-1888).

"Nietzsche, HAH, 1.

12 Ibid., 9.
} 
inveterate mendaciousness that one despairs of shedding becomes a stimulant. Now we discover in ourselves needs implanted by centuries of moral interpretation - needs that now appear to us as needs for untruth; on the other hand, the value for which we endure life seems to hinge on these needs. This antagonism - not to esteem what we know, and not to be allowed any longer to esteem the lies we should like to tell ourselves - results in a process of dissolution. ${ }^{13}$

The collapse of the cognitivist version of metaphysical realism indicates, in Nietzsche's view, the untenability of the extra-perspectival conception of knowing inherent in the God's Eye View of knowledge. Although this is an important aspect of his complete rejection of metaphysical realism, Nietzsche argues that the revelation that Reason is not an objective and disinterested cognitive tool that facilitates access to the world as it is in itself does not result in the complete collapse of metaphysical realism. Rather, metaphysical realism merely adopts an anti-cognitivist stance with regard to the "real" world. In his outline of the history of philosophy in Twilight of the Idols, Nietzsche traces the progressive demise of the rationalist conception of reality and our knowledge of it. I will cite this passage for the convenience of the reader.

HOW THE 'REAL WORLD' FINALLY BECAME A FABLE

\section{History of an Error}

1. The real world attainable for the wise man, the pious man, the virtuous man - he lives in it, he is it.

(Most ancient form of the idea, relatively clever, simple, convincing. Paraphrase of the proposition: 'I, Plato, am the truth').

2. The real world unattainable for now, but promised to the wise man, the pious man, the virtuous man ('to the sinner who repents').

(Progress of the idea: it becomes more cunning, more insidious, more incomprehensible - it becomes a woman, it becomes Christian---)

\footnotetext{
${ }^{13}$ Nietzsche, WP, 5 (1887).
} 
3. The real world unattainable, unprovable, unpromisable, but the mere thought of it a consolation, an obligation, an imperative.

(The old sun in the background, but seen through mist and scepticism; the idea become sublime, pale, Nordic, Königsbergian.)

4. The real world - unattainable? At any rate unattained. And since unattained also unknown. Hence no consolation, redemption, obligation either: what could something unknown oblige us to do?--

(Break of day. First yawn of reason. Cock-crow of positivism.)

5. The 'real world' - an idea with no further use, no longer even an obligation - an idea become useless, superfluous, therefore a refuted idea: let us do away with it!

(Broad daylight; breakfast; return of bons sens and cheerfulness; Plato's shameful blush; din from all free spirits.)

6. The real world - we have done away with it: what world was left? the apparent one, perhaps?---But no! with the real world we have also done away with the apparent one!

(Noon; moment of the shortest shadow; end of the longest error; pinnacle of humanity; INCIPIT ZARATHUSTRA.) ${ }^{14}$

Nietzsche's complaint here centres round his belief that philosophy has operated within a dualistic, two-world model. According to this model, our knowledge can only be adequate to reality if we disengage ourselves from our particular anthropomorphic interests. Stages one to four in Nietzsche's history of philosophy represent this two-world mode of thinking that has its origins in Platonism and Christianity. It is significant for our purposes that Nietzsche places Kant at stage three thus indicating that he considers that Kant too operates within this two-world mode of thinking. According to Nietzsche, Kant retains the rationalist faith in metaphysical realism in the guise of the inaccessible and unknowable thing-in-itself. In so doing, Kant adopts, in Nietzsche's view, the anti-cognitivist strain of metaphysical realism. Maudemarie Clark articulates Nietzsche's understanding of Kant's philosophy in the following manner:

\footnotetext{
${ }^{14}$ Nietzsche, Twilight, IV.
} 
According to the interpretation of Kant accepted by Nietzsche and many of his nineteenthcentury predecessors [---], Kant's denial that we can know things-in-themselves in effect affirms metaphysical realism. It implies that we cannot know the ultimate truth about things because we can know them only as they appear to beings of our cognitive constitution, and therefore that the truth is independent of our constitution. [---] This interpretation allows Kant, who explicitly defines truth as "agreement with the object" (A58/B82), to grant human beings access to truth if he treats appearances and things-in-themselves as distinct worlds or objects. [my emphasis] Understood in this way, his distinction between the phenomenal and noumenal - reality as it is in relation to beings of our constitution, versus reality as it is in itself - gives him two different kinds of truth, correspondence to noumenal reality, of which we are incapable, and correspondence to phenomenal reality, which contrary to Descartes, is all that either science or common sense give us. Kant is metaphysical realist about noumenal reality, but is anti-realistm [Clark's notation for anti-metaphysical realism] and therefore anti-Cartesian, about the only reality accessible to us. ${ }^{15}$

Nietzsche argues that Kant belongs to this metaphysical realist category because he retains the thing-in-itself as a metaphysical hangover from rationalist metaphysics. ${ }^{16}$ This hangover results, in Nietzsche's view, from Kant's acceptance of the demise of unmediated conceptual knowledge coupled with his retention of the idea that our human senses are unable to provide insight into the ultimate nature of reality. John Wilcox articulates Nietzsche's understanding of the role of the thing-in-itself in Kant's critical philosophy in the following.

His argument is that because our concepts did not square perfectly with the empirically given, philosophers reached precisely the wrong conclusion, namely, that there was something wrong with the empirical! The conceptual, then, was thought to refer to the real, the true world; and the senses were thought to reveal only the apparent, the false world - the very opposite of the truth. And then, with Kant, the true world becomes unknown even via concepts, and the thingin-itself stands over against the whole empirical-cum-rational world of phenomena; the concept has been brought back to where it belongs - into marriage with the senses - but its bastard

${ }^{15}$ Clark, Nietzsche on Truth and Philosophy, pp. 55-6. Nietzsche characterizes Kant's position as fostering both scepticism and relativism:

[--] despair of truth [---] attends every thinker who sets out from the Kantian philosophy, provided he is a vigorous and whole man in suffering and desire and not a mere clattering thought - and calculating machine [---] If Kent ever should begin to exercise any wide influence we shall be aware of it in the form of a gnawing and disintegrating skepticism and relativism [---].

[Friedrich Nietzsche, "Schopenhauer as Educator", 3 in Untimely Meditations, translated by R. J. Hollingdale, (Cambridge: Cambridge University Press, 1994)].

${ }^{16}$ It has been argued of course that Kant does not endorse a metaphysical realist understanding of truth. Although this is a highly respected interpretation it is not necessary that I consider it here. Nietzsche did not hold this view and since I am concerned to outline Nietzsche's dissatisfaction with metaphysical realism, I am interested in Kant's philosophy only to the extent that it makes manifest Nietzsche's contention with this world-view. 
offspring, the thing-in-itself, keeps the title "reality" which, by right, belongs only to the senses. And with the title goes honor; so the "true world," a phantom and a fallacy to begin with, receives more honor than the real world of the senses. Belief in concepts ends in disbelief in the world of the senses. ${ }^{17}$

In the final stage of his outline of the history of the "true" world Nietzsche indicates, by naming his mythic mouthpiece Zarathustra, that his own philosophy will take upon itself the task of undermining this two-world approach. Since Nietzsche thinks that the cognitivist version has suffered a death by its own hands it remains for him to overcome the anti-cognitivist version of metaphysical realism. I will begin to examine the manner in which Nietzsche succeeds in doing this in the next two sections. It will be seen that Nietzsche's main contention with metaphysical realism centers round the issue of the justification of our epistemic claims. Justification comprises, for the metaphysical realist, a correspondence between the way the world is, a priori, in itself and our epistemic and normative assertions. Although Nietzsche's desire to reconcile knowledge and metaphysics finds the idea of adequate knowledge attractive, he rejects the extra-perspectival and unmediated conception of knowledge that accompanies this view. With the demise of the cognitivist version, however, and its metamorphosis into the non-cognitivist version we witness what may be termed a decoupling ${ }^{18}$ of truth and justification whereby our ordinary experience of the world and the justification of our epistemic claims are denied the title "truth". Thus according to this version, truth-in-itself as the standard of justification and our actual practices of justification are radically divorced. In such a

\footnotetext{
17 John Wilcox, Truth and Value in Nietzsche, (Ann Arbor: The University of Michigan Press, 1974), p. 135.

18 I have borrowed this term from Michael Williams, "Realism and Scepticism" in Reality, Representation and Projection, (Oxford: Oxford University Press, 1993), pp. 193-215.
} 
case we witness what Nietzsche terms a severing of theory from practice. ${ }^{19}$ In theory, the anti-cognitivist metaphysical realist adopts a foundationalist approach to the question of truth and justification. However, in practice, given the cognitive inaccessibility of truth-in-itself, the non-cognitive metaphysical realist operates with possible falsehoods and illusions in the guise of beliefs that are lacking in epistemic worth. Nietzsche's anti-metaphysical realism aims to overcome this underlying foundationalist and anti-empirical approach. If he is to succeed in this he must satisfy a number of demands. Firstly, he must aim to overcome the anti-cognitivist version of metaphysical realism by recoupling truth and justification. He does this, as we shall see, by adopting a contextualist approach to these issues. This involves an antifoundationalist conception of justification whereby, contrary to the anti-cognitivist metaphysical realist idea that inaccessible "truth-in-itself" is the ultimate standard of justification and the consequent dissociation of truth and justification that this entails, Nietzsche claims that our practices of justification determine truth. Secondly, if Nietzsche is to succeed in recoupling truth and justification in this way, he must overcome the two-world view of both versions of metaphysical realism. In particular, he must overcome the anti-empirical tendency of this dualism. This anti-empirical tendency is evident in the insistence that the empirical arena of our ordinary lived experience cannot be an arena of truth but only of practical beliefs of doubtful epistemic status. If Nietzsche, then, is to recouple truth and justification in an antimetaphysical realist fashion he must establish that the empirical arena of our lived experience is conducive to truth and not radically divorced from it. Furthermore, if

\footnotetext{
${ }^{19}$ We here witness the alteration in my employment of the terms "theoretical" and "practical" that I
} 
the empirical world is to be conducive to a recoupling of truth and justification, then it must constrain our epistemic claims to the extent that it must curb any metaphysical realist pretensions to pure a priori truth in the form of the metaphysical hangover of the thing-in-itself. This criterion of empirical constraint entails a need for some form of realism that is compatible with Nietzsche's anti-metaphysical realist stance.

The remainder of this chapter will set about demonstrating the manner in which Nietzsche meets the above demands. This will involve an examination of both Nietzsche's perspectivism and empiricism, which, I will argue, yield an internal realist response to metaphysical realism. Internal Realism as I understand it in this context entails a theory-laden conception of truth and justification whilst subjecting our epistemic claims to a realist constraint. I will proceed by turning to Nietzsche's perspectivism.

\subsection{Nietzsche and Perspectivism}

Alan D. Schrift argues that Nietzsche distinguishes between three types of perspective. These can be described under the headings "physiological", "instinctual" and "socio-historical. ${ }^{20}$ Physiological perspectivism draws our attention to the role of the senses in knowing. Instinctual perspectives claim that our judgements have a "pre-history" in our instincts for preservation and growth. Socio-historical perspectives claim that our individual experiences and historically and socially accepted standards of truth and falsehood condition the scope of our knowledge. All

signaled in the introduction to this chapter. 
three characterizations bring to the fore Nietzsche's argument that knowledge is a contextual and empirical affair in opposition to the epistemological disinterestedness of metaphysical realism. In this section I will focus my analysis on the contextual and anti-foundationalist aspects of Nietzsche's anti-metaphysical realism. I will embark on an exploration of Nietzsche's empiricism in the third section.

As a form of anti-foundationalist thought, Nietzsche's perspectivism is designed to counteract the metaphysical realist correspondence theory of truth and justification. In so doing, Nietzsche aims to replace the metaphysical realist view from nowhere with the perspectivist view from somewhere. He defines a perspective as an "interest of certain types of life"21 arguing that our truths are irretrievably entwined with our interests. Perspectivism aims to induce, contrary to the metaphysical realist, a form of epistemological modesty by claiming that we cannot acquire extra-perspectival knowledge. Extra-perspectival knowledge is conceivable, according to Nietzsche, only if we permit both the objectionable concept of the thingin-itself or Platonic eternal verities and the necessary rationalist cognitive tools. We have seen that genealogical and historical inquiry reveal, in Nietzsche's view, that what was considered extra-perspectival knowledge was in fact only a perspective. Since the God's Eye View and the thing-in-itself are mutually dependent on one another, according to Nietzsche, the demise of one must lead to the inevitable collapse of the other. Christoph Cox articulates this point when he says:

\footnotetext{
${ }^{20}$ Alan D. Schrift, Nietzsche and the Question of Interpretation, (London: Routledge, 1990), p. 146.

${ }^{21}$ Nietzsche, WP, 293 (1888).
} 
Nietzsche's point is that, without access to a God's-eye view capable of confirming the existence of a thing in itself and distinguishing it from its appearances, we have no basis for making such a distinction at all and thus no basis for skepticism. ${ }^{22}$

Thus, in keeping with his epistemic quarrel with metaphysical realism Nietzsche's anti-metaphysical realist stance must deny that reality is epistemically inaccessible to our cognitive constitution. He does this by arguing that the concept of the thing-initself or a metaphysical world that is inaccessible to our cognitive faculties is a contradiction in terms. Nietzsche argues that it is impossible to conceptualize such a notion. ${ }^{23}$ This impossibility, he claims, renders it an idea "empty of meaning" 24 that can only be defined negatively:

[--] there is nothing at all we could state about the metaphysical world except its differentness, a differentness inaccessible and incomprehensible to us. It would be a thing with negative qualities. $^{25}$

Any attempt to conceptualize what is perforce for Nietzsche unconceptualizable is a fruitless activity to the extent that, he argues, "We cannot look around our own corner: it is a hopeless curiosity that wants to know what other kinds of intellects and perspectives there might be [--]. ${ }^{, 26}$ With this Nietzsche introduces the criteria for his anti-metaphysical realism. The reach of our perspectives becomes the boundary of

${ }^{22}$ Christoph Cox, Nietzsche: Naturalism and Interpretation, (London: University of California Press), p. 177. Rorty makes a similar observation:

"Truth" in the sense of "truth taken apart from any theory" and "world" taken as "what determines such truth" are notions that were (like the terms 'subject' and 'object', 'given' and 'consciousness') made for each other. Neither can survive apart from the other. [Richard Rorty, Consequences of Pragmatism, (London: Harvester Wheatsheaf, 1991), p. 15].

${ }^{23}$ In Thus Spoke Zarathustra, translated by R. J. Hollingdale, (London: Penguin, 1969), II, 2, Nietzsche states:

God is a supposition: but I want your supposing to be bounded by conceivability.

Could you conceive a god? - But may the will to truth mean this to you: that everything shall be transformed into the humanly-conceivable, the humanly-evident, the humanly palpable! You should follow your own senses to the end!

${ }^{24}$ Nietzsche, HAH, 16.

${ }^{25}$ Ibid., 9. 
both intelligibility and rational acceptability. ${ }^{27}$ Thus perspectivism narrows our interest in truth to truth "for us" as opposed to, what he considers to be, the implausible metaphysical realist notion of truth-in-itself.

Maudemarie Clark captures Nietzsche's thinking in this respect when she defines metaphysical realism as the view that truth is independent of both our cognitive capacities and cognitive interests. Our cognitive capacities are subject to development and change. It is thus conceivable that there are cognitive subjects with greater cognitive abilities than us. Such a being would be similar to Mark Johnston's Ubiquitous detector that has enhanced observational capacities. ${ }^{28}$ Our cognitive interests, on the other hand, may be construed as that which "we could ever want"29 from a theory. Clark claims that our standards of rational acceptability express the cognitively relevant properties that we want from a theory. Thus our cognitive interests can be defined as that which is cognitively useful ${ }^{30}$ to us. ${ }^{31}$ Such interests

\footnotetext{
${ }^{26}$ Friedrich Nietzsche, The Gay Science, translated by Walter Kaufmann, (New York: Vintage, 1974), 374. Hereafter cited as GS.

${ }^{27}$ My examination pertains only to those perspectives that are, in Nietzsche's view, "justified" and worthy of the status of cognitive belief. He, of course, acknowledges that there are many types of perspective. However, he denies that they are all "cognitive" or serious contenders for truth. Thus Nietzsche denies that the religious belief in an after-life, for example, is a valid perspective. He claims that this belief is "an error in the interpretation of certain natural events, a failure of the intellect." (GS, 151).

${ }^{28}$ Mark Johnston, “Objectivity Refigured: Pragmatism Without Verificationism", in John Haldane and Crispin Wright (eds.), Reality, Representation and Projection. (Oxford: Oxford University Press, 1993), p. 92.

${ }^{29}$ Clark, Nietzsche on Truth and Philosophy, p. 48.

${ }^{30}$ Note that in his outline of the history of philosophy from Twilight cited earlier, Nietzsche describes the idea of the "real" world as "useless" at stage 5.

${ }^{31}$ Clark, Nietzsche on Truth and Philosophy, p. 98.

Peter Poellner raises some objections to Clark's argument. ["Perspectival Truth" in John Richardson and Brian Leiter (eds.), Nietzsche, (Oxford: Oxford University Press, 2001)] He articulates Clark's understanding of Nietzsche's rejection of the thing-in-itself as a rejection of two propositions:

(1) there might be real items which cannot be known by any conceivable knowers, whatever their cognitive capacities.
} 
are, for example, explanatory success and the simplicity of a theory. ${ }^{32}$ Clark

articulates the metaphysical realist view in the following way.

Truth is independent not simply of what we now want, but of what we could ever want, that is, of what we would want even under ideal conditions for inquiry for beings like ourselves. ${ }^{33}$

This view leaves open the possibility that our beliefs may be massively in error in a

similar manner to Descartes' subject deceived by the demon or the brain in a vat that

is deceived by the master scientist. Given this possibility, the metaphysical realist

thinks it intelligible that our beliefs about the world may be illusory bearing no

(2) a theory, which ideally satisfies the best possible human standards of rational acceptability, might fail to be true. Among these best standards are comprehensiveness, coherence and predictive success.

In response to the rejection of the second proposition Poellner maintains that "it would be easy to define an appropriate idealization of Clark's standard of comprehensiveness over sets of beliefs, according to which the best possible theory to be aspired to by us (our regulative ideal) is one which, besides satisfying various other standards, includes existentially quantified propositions representing all states of affairs conceivable by a being with idealized cognitive capacities (Clark's theory allows for such an idealization of cognitive capacities)". (p. 96n). Thus Poellner maintains that the rejection of proposition (2) can be reduced to the rejection of proposition (1). He argues that no state of affairs could remain beyond a theory that satisfied a being with idealized cognitive capacities. Thus he maintains that proposition (2) places no additional constraints on what can be the case and thus that Clark's presentation of Nietzsche's argument against the thing-in-itself can be reduced to the rejection of proposition (1). Moreover, Poellner contends that the rejection of proposition (1) places no constraint on what can be considered to be the case because nobody has ever subscribed to proposition (1).

However, Poellner's objection to Clark can only be an objection to my argument here if we do not make a clear distinction between cognitive capacities [issue of proposition (1)] and cognitive interests [issue of proposition (2)]. By arguing that proposition (2) can be reduced to proposition (1), Poellner suggests that our cognitive interests can be reduced to our cognitive capacities.

According to my argument, cognitive interests represent our best standards of rational acceptability (our best reasons for holding a theory to be true) and are not to be misconstrued as the idealization of our cognitive capacities. Moreover, dependence on our cognitive interests is designed to allow that there are extra-perspectival properties in the world without allowing this possibility to cast doubt upon our truths. Dependence on our cognitive interests stipulates that the nature of reality can only cast our truths into massive error if the nature of such reality can be articulated in a rational format familiar to us. That Nietzsche holds such a position is suggested in HAH, 9 where he maintains that the thing-in-itself is meaningless because it cannot be articulated in such a familiar rational format and thus that the thing-in-itself is merely a thing with negative qualities. Thus my argument here is that reality may be independent of our cognitive capacities to the extent that there is room for discovery. However, truth cannot be independent of our cognitive interests to the extent that all such discoveries are judged and given the status of knowledge, or not, in accordance with our idealized cognitive interests. Construed in this way it seems that cognitive interests cannot be so readily reduced to cognitive capacities in the manner that Poellner's argument suggests.

32 Clark actually mentions predictive rather than explanatory success. However, I have mentioned explanatory success because Nietzsche rarely speaks of prediction but has an interest in the issue of explanation. For Nietzsche's on explanation see Chapter Four. 
significant cognitive relation to how the world is in itself. Such a view considers truth to be independent of both our cognitive capacities and interests. The situation depicted in the demon scenario transcends our capacities in the sense that it is beyond our detective abilities to discern whether the beliefs induced in us by the demon are adequate to the true nature of reality. It is independent of our interests to the extent that it implies that, without a divine guarantee, a theory that gave us all we could ever want from a theory might nevertheless be massively in error. Thus truth is independent of our cognitive interests if it is claimed that our cognitive engagement with the world may be radically false. In order to close the possibility of massive error anti-metaphysical realism, in contrast, must maintain, that truth is dependent on our cognitive interests but independent of our cognitive capacities. It must be independent of our cognitive capacities in order to allow for the real possibility of increased observational abilities and discovery etc. However, it must be dependent upon our cognitive interests in order to rule out the possibility of casting our beliefs into massive error. Thus anti-metaphysical realist truth is dependent on what we could ever want from a theory understood as that which is intelligible to cognitive subjects with our mode of rationality. This entails that a proposition or theory, which is supported by the best reasons we have for holding that particular view, cannot be radically in error. This is suggested by Nietzsche's association of our best reasons (our consideration of multiple perspectives and the balancing of reasons for and against a view) with the quest for certainty:

[-] the great majority of people does not consider it contemptible to believe this or that and to live accordingly, without first having given themselves an account of the final and most

\footnotetext{
${ }^{33}$ Clark, Nietzsche on Truth and Philosophy, p. 48.
} 
certain reasons pro and con [my italics], and without even troubling themselves about such reasons afterward: [---] But what is goodheartedness, refinement or genius to me, when the person who has these virtues tolerates slack feelings in his faith and judgments and when he does not account the desire for certainty as his inmost craving and deepest distress [--- $]^{34}$

Here Nietzsche sets up the arena in which truth claims are to be justified. If antimetaphysical realist truth is independent of our cognitive capacities but dependent on our cognitive interests, then, it is dependent on what is intelligible or conceivable to us, and thus on our best reasons for holding a belief. The point here seems to be that regardless of what information we come by in the future, the acquisition of such information cannot falsify our perspectival take on the world in a radical sense. In other words, the acquisition of further information will not globally falsify our bestjustified theory. Thus Clark states that anti-metaphysical realism must reject the metaphysical realist view that

[---] truth is independent not only of what we could in principle have reason to accept, but also of what any conceivable intelligence [my italics] could have reason to accept, given our best standards of rational acceptability. ${ }^{35}$

The anti-metaphysical realist model outlined above is somewhat similar to the one proffered by Donald Davidson. Davidson argues that it is conceivable that there are beings with superior cognitive capacities to our own. Such a being would be what Davidson terms the omniscient interpreter. According to Davidson, the omniscient interpreter can only deem our beliefs false by entering into cognitive communication with us. The possibility of such communication, however, presupposes a background

\footnotetext{
${ }^{34}$ Nietzsche, GS, 2. In GS, 319 Nietzsche again insists on "intellectual conscience" and the justification of belief in opposition to, what he calls, the religious interpretation of experience:

[--] they thirst after things that go against reason, and they do not wish to make it too hard for themselves to satisfy it. So they experience "miracles" and "rebirths" and hear the voices of little angels! But we, we others who thirst after reason, are determined to scrutinize our experiences as severely as a scientific experiment - hour after hour, day after day. We ourselves wish to be our experiments and guinea pigs.
} 
of agreement on most matters. Thus, Davidson contends that "objective error can occur only in a setting of largely true belief" ${ }^{36}$ From this we can see that the omniscient interpreter can cast our perspectival belief into massive error only within the framework of our own standards of rational acceptability. The possibility of massive error, in other words, must be translatable into a rational format familiar to us. Metaphysical realism, according to Nietzsche, is one such untranslatable position. Such an untranslatable viewpoint can have, in Nietzsche's view, no cognitive purchase for us. It would be a view from Nowhere, an impossible attempt to "look around our own corner".

However, one could argue that unless this anti-metaphysical realist account of truth allows for properties in the world that transcend our interests or perspectives Nietzsche is committed to a form of subjective idealism in the sense that to be is to be of some interest to a human cognitive subject. Equally it may be argued from some quarters that if this is not the case and he is not committed to such an idealist view, then, he must allow for extra-perspectival properties in the world and in so doing, Nietzsche despite his claims to the contrary, embraces metaphysical realism. ${ }^{37}$

In order to allay the first objection we must be clear about what is meant by perspectives or cognitive interests. Let me state my claim from the outset in order to avoid confusion later on. It seems to me that Nietzsche's perspectivism must be construed primarily as an epistemic thesis about what we can know rather than a

\footnotetext{
${ }^{35}$ Clark, Nietzsche on Truth and Philosophy, p. 48.

${ }^{36}$ Donald Davidson, "The Method of Truth in Metaphysics" in Inquiries into Truth and Interpretation, (Oxford: Oxford University Press, 1984), p. 200.

${ }^{37}$ See Peter Poellner, Nietzsche and Metaphysics, (Oxford: Clarendon Press, 1995), pp. 33-4.
} 
metaphysical thesis about what there is in a global sense. ${ }^{38}$ Thus I take Nietzsche's perspectivism to maintain that our manner of knowing the world is perspectival and not that the world itself is metaphysically reducible to our perspectives. Thus, as Brian Leiter remarks, correctly I believe, perspectives are conditions of knowing objects and are not constitutive of objects. ${ }^{39}$ That this is Nietzsche's view can be witnessed from the following citation:

There is only a perspectival seeing, only a perspectival "knowing" [my italics]; and the more affects we allow to speak about a matter, the more eyes, different eyes, we know how to bring to bear on one and the same matter, that much more complete will our "concept" of this matter, our "objectivity" be. But to eliminate the will altogether, to disconnect the affects one and all, supposing that we were capable of this: what? Would that not be to castrate the intellect? ${ }^{40}$

Now let us address the second query. We can see that Nietzsche does allow for such extra-perspectival (that is, non-reducible) properties in the world. He states:

[--] we have senses for only a selection of perceptions - those with which we have to concern ourselves in order to preserve ourselves. ${ }^{41}$

However, in the light of the epistemic understanding of Nietzsche's perspectivism that I am proposing, the most fruitful way of reading Nietzsche's rejection of metaphysical realism is as a thesis about knowability. Metaphysical realism, as it was presented in the first section of this chapter, represents, for Nietzsche, the view that the world is inaccessible to our perspectival mode of knowing. Inaccessibility is here taken as synonymous with the possibility of massive error. The world is inaccessible

\footnotetext{
${ }^{38}$ In chapter four we will see that Nietzsche construes the world as composed of a hierarchy of perspectival forces. However, there we will see that Nietzsche justifies this metaphysical thesis by prioritizing epistemology over metaphysics. It is in this sense of priority that I construe Nietzsche's perspectivism as an epistemic thesis in this chapter. I am not here concerned to discuss Nietzsche's positive metaphysics. This is best left until chapter four.

${ }^{39}$ Brian Leiter, "Perspectivism in Nietzsche's Genealogy of Morals" in Richard Schacht (ed.) Nietzsche, Genealogy, Morality, (London: University of California Press, 1994), p. 350.

${ }^{40}$ Friedrich Nietzsche, On the Genealogy of Morality, translated by Maudemarie Clark and Alan J. Swensen, (Indianapolis: Hackett Publishing Company, 1998), III, 12. Henceforth cited as GM.

${ }^{41}$ Nietzsche, WP, 505 (1885-6).
} 
in the light of the demise of pure a priori forms of knowledge which, it seems from my adumbration of it in section one, is the only mode of access to the "real" world for the metaphysical realist. The "true" world in this metaphysical realist sense, following the demise of rationalist metaphysics, is construed as the "hidden" but proper foundation of our epistemological claims. As such it is independent of our cognitive interests in the sense that our human perspectival take on reality may be radically false. In this context the possibility of extra-perspectival properties is problematic for Nietzsche only if they are capable of casting our best justified perspectival truths into massive error. However, we have seen that this possibility is unintelligible in the sense of untranslatable to us and therefore of no cognitive purchase. If this is the case, then, Nietzsche's acceptance that the world itself is metaphysically independent of us and so not reducible to our perspectives is the acceptance of a world that constrains our epistemic theories but not one that grounds our truth claims. Nietzsche makes this point in Human, All Too Human, 9 where he ambivalently refers to the world that is not reducible to our perspectival takings as the "metaphysical world". Here Nietzsche argues that it is theoretically possible that there is a metaphysical world but that, contrary to the metaphysical realist, this possibility can have no bearing on the epistemic status of our best justified beliefs. This is because, as Nietzsche brings out in this and surrounding passages, metaphysical possibility does not coincide with epistemic possibility. The metaphysical world, Nietzsche argues, is mistakenly construed as radically different from the world we are familiar with to the extent that it is believed that it can radically falsify our present beliefs. However, Nietzsche suggests that reality may 
transcend our perspectival takings in the sense of not being reducible to them, but it cannot cast our present beliefs into massive error. Thus Nietzsche contends that metaphysical possibility is not very suited to cause men worry since metaphysical possibility alone cannot carry any serious epistemic consequences for us. ${ }^{42}$ On this basis, we can see that, for Nietzsche, every perspective is a perspective on the world. The fact that the world transcends, in the particular sense of not being reducible to, our interests does not entail for Nietzsche that the world is inaccessible and unknowable in principle. What Nietzsche's perspectival theory of knowledge does rule out, however, is the possibility of a supra-perspectival and therefore God's Eye View of the world. The God's Eye View is committed to a recognition-transcendent view of truth. As such Nietzsche's metaphysical realist is akin to what John Haldane terms the ultra-realist that insists upon "the unconditional transcendence of reality

\footnotetext{
${ }^{42}$ Nietzsche presents the indifferentist argument against the thing-in-itself in HAH. It entails the view that knowledge of the thing-in-itself is useless knowledge because it cannot make any practical difference to us. However, Nietzsche's argument here is considerably stronger than just this. By tracing the genealogy of the belief in the thing-in-itself, he argues that this belief originates in a false estimation of the world. This implies, in his view, that there cannot be a thing-in-itself whose nature is radically different from the world that we are familiar with and thus capable of casting our beliefs into radical doubt. In so doing, Nietzsche proffers some hint that this conception of the thing-in-itself is epistemically impotent.

In "Perspectival Truth" (section 4) Peter Poellner has presented the conceivability argument presented in the main text above and the metaphysical indifferentism argument as two incompatible arguments. Moreover, Poellner maintains that the indifferentism argument is Nietzsche's real argument against the thing-in-itself. Poellner cites Twilight, IV, and HAH, 9 in support of his claim. The metaphysical indifferentism argument maintains, in Poellner's view, that it is possible that there are absolute extra-perspectival properties in the world but that such a possibility does not warrant our concern. Poellner is indeed correct in stating that Nietzsche claims that we are indifferent to the possibility of extra-perspectival properties in the world. However, the conceivability argument, according to Poellner, maintains that absolute objects are impossible (Poellner p. 111). Along these lines both the indifferentist and the inconceivability argument are incompatible with one another.

I have read the conceivability argument in a different way. I have interpreted it as maintaining that truth is independent of our cognitive capacities but dependent on our cognitive interests. This suggests that it is possible that there are extra-perspectival properties but that this possibility is not capable of falsifying our epistemic claims from within the confines of our standards of rational acceptability and intelligibility. Read in this way the conceivability argument is a version of the metaphysical indifferentist argument to the extent that we are unconcerned about the possibility of extra-perspectival properties because they lack the power to cast our beliefs into radical doubt.
} 
over our natural means of coming to know about the world" ${ }^{43}$ Thus we may construe

Nietzsche's perspectivism as an attempt to counteract such an ultra-realist

foundationalist theory in favour of a perspectival and anti-foundationalist view.

David Owen captures these characteristics of the Nietzschean perspective when he

defines perspectives as affectually bound bundles of judgements about the world. A

perspective may thus be construed as a complex of beliefs about the world rooted in

our common practical interests. ${ }^{44}$ According to Nietzsche, a perspective, thus defined,

is the determinate manner in which the world can be known. It is the manner in which seeing becomes seeing something. ${ }^{45}$ As conditions of knowledge, perspectives

are, construed by Nietzsche as, the contextual basis of justification. Maudemarie

Clark captures this aspect of Nietzsche's perspectivism when she states:

To be analogous to the visual case, a cognitive perspective must be something on the side of the knower that affects the intellectual "look" of the object, that affects how it is understood or interpreted. An obvious candidate for this role is our corpus of beliefs, what we believe at a particular time. Calling knowing perspectival suggests that how things will look to us intellectually in any situation - how we are justified in interpreting them - depends on "where we're at," that is, on what we already believe. To consider knowledge nonperspectival would be to insist that it must be grounded in a set of foundational beliefs, beliefs all rational beings must accept no matter what else they believe, beliefs that could therefore constitute a neutral corner from which the justifiability of other beliefs might be assessed. In calling nonperspectival knowledge "an absurdity and a nonsense," Nietzsche suggests the impossibility of such self-justifying foundations for knowledge. ${ }^{46}$

43 John Haldane, "Mind-World Identity Theory and the Anti-Realist Challenge" in John Haldane and Crispin Wright (eds.), Reality, Representation and Projection, (Oxford: Oxford University Press, 1993), p. 34.

44 David Owen, Nietzsche, Politics and Modernity, (London: Sage Publications, 1995), pp. 36-7.

${ }^{45}$ Nietzsche, GM, III, 12.

${ }^{46}$ Clark, Nietzsche on Truth and Philosophy, p. 130.

Steven D. Hales and Rex Welshon object to the above identification of perspectives and beliefs in Nietzsche's Perspectivism, (Urbana: University of Illinois Press, 2000). They argue that to think of a perspective as a belief is "to slip from a statement is held true (or believed true) in a perspective" to "a statement is true in a perspective". (p. 20). They take this to mean that a perspective, if identified with a belief, could not possibly be false. They argue that Nietzsche did not hold the latter view because he "holds that there can be untrue beliefs within a perspective, and this would not be possible if a perspective were defined as a set of beliefs." (pp. 19-20). Thus Hales and Welshon argue that the chief difficulty with the identification of perspectives and beliefs is that "it would make people infallible". ( $p$. 20). Furthermore, they maintain that this identification precludes the possibility of discovery. They ask, "If belief is sufficient for truth, then how could anyone discover something to be true?" (p. 20). 
From this we can see that Nietzsche's perspectivism rejects the metaphysical realist understanding of objectivity as a God's Eye View from Nowhere in favour of a multiperspectival viewpoint that overcomes the metaphysical realist decoupling of truth and justification. This is achieved by rejecting the notion of truth-in-itself in favour of Nietzsche's conception of truth for us whereby our actual practices of justification determine truth. The distinction between the two views can be seen in Leiter's distinction between strong and weak objectivity. Leiter defines metaphysical realist strong objectivity, to the extent that it allows for the possibility of massive error, as that which is independent of both our cognitive capacities and interests. Leiter states of strong objectivity that

[--] global independence from human evidence or belief [---] is the mark of objectivity. Thus, a fact is strongly objective only if everything we believe about it and all the evidence we have about it - even at the ideal limit - could prove mistaken. Strong objectivity, then, requires that global error be an intelligible possibility. ${ }^{47}$

Weak objectivity in contrast, for Nietzsche, entails the consideration of multiple perspectives with regard to a matter:

The mistake made by Hales and Welshon here, it seems to me, is to see the identification of perspectives and beliefs as entailing the view that belief is a sufficient criterion of truth. In this thesis 1 am arguing that perspectives as beliefs are necessary to initiate inquiry but not that they are sufficient. Rather, I here maintain that Nietzsche distinguishes between more and less worthy perspectives. A worthy perspective, for Nietzsche, according to my reading, is one that is constrained by reality. A less worthy perspective is not so constrained and thus has no epistemic value. Nietzsche suggests such a view when he argues that Christianity is a false interpretation of reality:

The metaphysical need is not the origin of religions, as Schopenhauer supposed, but merely a late offshoot [--] what first led to the positing of "another world" in primeval times was not some impulse or need but an error in the interpretation of certain natural events, a failure of the intellect. (GS, 151).

Moreover, Hales and Welshon's view suggests that the identification of perspectives with belief renders our epistemic claims unrevisable and fixed. However, as we saw in chapter one, Nietzsche considers beliefs to be "provisional assumptions" that regulatively rather than constitutively direct and initiate inquiry. Considered in this way, belief, rather than hindering the pursuit of truth, is a necessary condition of the pursuit itself. Nietzsche states:

Believing is the primal beginning even in every sense impression: a kind of affirmation the first intellectual activity! (WP, 506, 1884).

${ }^{47}$ Brian Leiter, "Perspectivism in Nietzsche's Genealogy of Morals", p. 349. 
There is only a perspectival seeing, only a perspectival "knowing"; and the more affects we allow to speak about a matter [---] that much more complete will our "concept" of this matter, our "objectivity" be. 48

Leiter, in a similar manner to Clark, takes Nietzsche's acceptance of weak objectivity as grounds for endorsing a common sense realist view that counteracts both metaphysical realism and the falsification thesis or the possibility of global error. It is suggested that if objectivity is defined by our perspectival take on the world, then, truth cannot globally transcend our best-justified human beliefs. This reading is intended as a rebuttal of those who construe Nietzsche's perspectivism as only a negative thesis that claims that our knowledge is "merely" perspectival. This negative view carries with it two principal implications for my present reading. Firstly, it suggests that our perspectives (as our best justified beliefs) are unconstrained by reality. Secondly, if our perspectives are unconstrained in this way then the negative reading allows for the possibility of a metaphysical realist decoupling of justification and truth by conceding that our perspectival practice of justification may be massively in error. In the remainder of this chapter we shall see that if Nietzsche is to overcome metaphysical realism he must succeed in establishing a realist constraint to our theorizing. In the penultimate section we will see that Nietzsche succeeds in meeting this requirement. For the present, however, I will proceed to examine Nietzsche's empiricism.

\footnotetext{
${ }^{48}$ Nietzsche, GM, III, 12.
} 


\subsection{Nietzsche's Empiricism}

It is important for our purposes that we can establish that Nietzsche adopts an empirical approach to the question of truth. Nietzsche's empiricism is particularly significant for his attempt to overcome hierarchical dualism. The latter view is rooted, he claims, in a philosophy of resentment that rejects the empirical world of our lived experience by positing another inaccessible world as the standard of the true and the real. Nietzsche argues that we can only overcome resentment with an affirmation of the empirical world as a valid arena for philosophical inquiry. He states that "Our senses are the first origin of all credibility, all good conscience, all apparent truth" ${ }^{49}$ That this appeal to empirical criteria is intended as an affirmative response to the anti-empirical dualistic philosophy of resentment can be seen from Nietzsche's claim that "In Christianity neither morality nor religion come into contact with reality at any point" ${ }^{50}$ Moreover, my findings in chapter one indicated that such an affirmation must create a role for empirical content that is neither devoid of, nor opposed to, conceptual form. With this in mind let us now explore the nature of Nietzsche's empiricism. My aim in discussing Nietzsche's empiricism is twofold. Firstly, I want to establish that his perspectivism succeeds in overcoming the antiempirical tendency of metaphysical realism. In so doing, I want to establish that, for Nietzsche, the empirical world plays a role in our epistemic claims without acting as an epistemological foundation for those claims. By this I mean that, for Nietzsche,

\footnotetext{
49 Nietzsche, Beyond Good and Evil, translated by Marion Faber, (Oxford: Oxford University Press, 1998), 134. Hereafter cited as BGE.

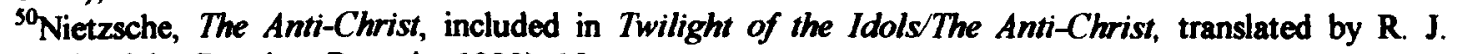
Hollingdale, (London: Penguin, 1990), 15.
} 
the empirical world of our lived experience is the arena within which our truth claims are worked out, and not an extra-theoretical standard extrinsic to our actual practices of justification. Secondly, if the world is to properly constrain our truth claims and thus curb metaphysical realist pretensions to an anti-empirical conception of truth then we must commit ourselves to some form of realism. However, this issue has been a matter of contention amongst those Nietzsche interpreters that argue that his anti-metaphysical realist stance entails counterintuitive implications and those others that claim that a realist reading of Nietzsche commits him to metaphysical realism all over again. In this section I will deal with the first issue outlined above and leave my treatment of the realism issue until the penultimate section. I will now proceed with an elucidation of Nietzsche's empiricism by citing a passage where he would appear to adopt a loosely Kantian schema:

[---] questions, what things "in-themselves" may be like, apart from our sense-receptivity and the activity of our understanding, must be rebutted with the question: how could we know that things exist? "Thingness" was first created by us. ${ }^{31}$

R. Lanier Anderson interprets Nietzsche at this point as adopting the physical synthesis account of knowledge often attributed to Kant. This view claims that cognitive subjects actively "organize" sense-data. Richard S. G. Brown articulates this view as follows:

Since the manifold or given is accepted as utterly chaotic, Nietzsche argues that we first undertake a physical synthesis in order to obtain "things" which only subsequently can serve as the basis for judgments about them. ${ }^{52}$

\footnotetext{
${ }^{51}$ Nietzsche, WP, 569 (1887).

52 Richard S. G. Brown, "Nietzsche and Kant on Permanence" in Man and World, Volume 13, 1980, p. 45 .
} 
In what follows I will argue that there are textual grounds to suggest that Nietzsche's adoption of the Kantian schema does not result in the physical synthesis view. Rather I will suggest that the Kantian language employed by him in the above passage is intended to emphasize the perspectival orientation of our knowledge and thus disallow appeals to extra-perspectival facts. It is important for our purposes that we avoid committing Nietzsche to such a view. Firstly, it commits him to a constitutive conception of knowledge which, in chapter one, I argued Nietzsche rejects. Secondly, physical synthesis harbours foundationalist implications that Nietzsche also wants to avoid. It does this by claiming that we can have knowledge only of representations that are the result of an organization of uninterpreted sense-data. Such organizations are said to falsify reality in a global sense. The possibility of such global falsification would commit Nietzsche to a form of foundationalist phenomenalism to the extent that unfalsified reality would be equated with the flux of uninterpreted sense-data. Such a view is foundationalist to the extent that these sense-data are misconstrued as the ineffable true foundation of our epistemic judgements. However, as indicated above, I will argue that although Nietzsche's appeal to experience is designed to act as a constraint on our judgements, it does not act as a non-propositional and, therefore, supra-perspectival foundation for the justification of our epistemic claims. This can be witnessed principally in Nietzsche's rejection of Positivism's appeal to "facts":

Against Positivism, which halts at phenomena - "There are only facts" - I would say: No, facts is precisely what there is not, only interpretations. We cannot establish any fact "in itself": perhaps it is folly to want to do such a thing. ${ }^{33}$

${ }^{53}$ Nietzsche, WP, 481 (1883-8). 
Thus Nietzsche argues that our sensations are always already permeated with value judgements. ${ }^{54}$ By this I take him to mean that what we are acquainted with are sensory beliefs or perspectives rather than "uninterpreted" sense-data. He states:

There could be no judgments at all if a kind of equalization were not practised within sensations [my italics]: memory is possible only within a continual emphasising of what is already familiar, experienced. - Before judgment occurs, the process of assimilation must already have taken place; thus here, too, there is an intellectual activity that does not enter consciousness, as pain does as consequence of a wound. Probably an inner event corresponds to each organic function; hence assimilation, rejection, growth, etc. ${ }^{\text {ss }}$

Allow me to cite Brian Leiter whose explanation of Sellars' rejection of the sensory given seems to capture Nietzsche's meaning.

The heart of the Sellarsian critique appears to be this: that we can't both construe the "confrontation" with experience as nonpropositional and at the same time have this experience play a role in the justification of belief. "Confrontations" with experience must, it seems, enter the "logical space of reasons" in order to justify belief; but allowing that entry undercuts the noninferential warrant of the "given" - which must now itself, like all other propositional claims, be justified as well. Put simply, and in more Davidsonian terms, objects may cause beliefs, but only other beliefs (e.g about objects) can justify beliefs. ${ }^{56}$

By positing experience as a constraint on our perspectival interpretations, Nietzsche aims to overcome the metaphysical realist quest for pure conceptual or a priori access to the "true" world unhindered by appeal to sense-experience. It is in this vein that Peter Poellner argues that, according to Nietzsche, the concept of an object needs to be elucidated by 'the ability to contentfully conceive of, or imagine, by means of what I have called a representational content, an instantiation of such a concept". 57 Poellner defines a representational content as the "object side" of representational states such as dreaming, imagining or perceiving. A representational content involves

[--] some kind of qualitative, sensory, or quasi-sensory or, more generally, intuitive 'filling'. A representational content is what such a state is said to be of. Thus, for example, when I

\footnotetext{
${ }^{54}$ Ibid., 505 (1885-6).

55 Ibid., 532 (1885).

${ }^{56}$ Brian Leiter, "Perspectivism in Nietzsche's Genealogy of Morals, p. 355n22.

${ }^{57}$ Peter Poellner, Nietzsche and Metaphysics, p. 87.
} 
imagine touching a solid cube of such-and-such a size, solidity, and surface structure, it is these instantiated properties, as apprehended from a certain perspective, which constitute the representational content of my representational state. ${ }^{58}$

From this we can see that, according to Nietzsche, our sense-experience acts as a constraint to our judgements in the sense that we cannot determine the course and nature of our experience at will. However, this experience is always perspectivally oriented in order for it to play any epistemic role in the justification of our beliefs. It seems, then, that Nietzsche was aware of the epistemic impotency of foundational empiricism. Appeal to uninterpreted sense-data, as Michael Williams points out, can neither act as the foundation of our judgements nor constrain those judgements:

\begin{abstract}
Since the apprehension of the given element is supposed to provide the ultimate check upon empirical knowledge, it must itself be some form of primitive knowledge or awareness. But when we recall the sharp distinction between the pure concept and the sensuously given, a problem arises. The pure concept and the sensuously given are thought [--] to be mutually independent - 'neither limits the other' - but this makes it look as if the mind has to be able to grasp the given without conceptual mediation. In other words, the knowledge which is involved in the grasping of the sensuously given, since it is independent of conceptual interpretation by the mind, must be non-propositional or, to put the point more pejoratively, ineffable. But if it is ineffable, it cannot provide us with a check upon anything, let alone the entire edifice of empirical knowledge. ${ }^{59}$
\end{abstract}

For Nietzsche, then, it seems that we are dealing with the world not as "given" but as "taken". The anti-metaphysical realist view from somewhere is now complete. Nietzsche has now established an empirical and contextual framework of justification. Having reached this stage I can now address the issue, raised earlier, concerning the nature of Nietzsche's empiricism and whether it carries, in Nietzsche's view, counterintuitive (idealist) or commonsense (realist) implications. I will take commonsense realism to be a form of internal realism that advocates that

${ }^{38}$ Ibid., p. 88. 
truth is dependent on our cognitive interests as our standard of rational intelligibility whilst maintaining the independent existence of the world. With this in mind I will proceed to examine the idealist/realist debate concerning Nietzsche's writings.

\subsection{Idealist/Realist Debate}

Nietzsche's rejection of metaphysical realism has been interpreted in different ways. Maudemarie Clark argues that he adopts a commonsense realist approach in his last six books where, she claims, Nietzsche abandons a simultaneous commitment to both the incompatible views of phenomenalism and subjective idealism. Lanier Anderson, however, sees Nietzsche's perspectivism as entailing counterintuitive implications for our commonsense realist beliefs throughout Nietzsche's entire philosophical career. Such counterintuitive implications derive from the physical synthesis interpretation of Nietzsche outlined earlier. Lanier Anderson states:

[---] the truth about the world - and thus the way things are with the objects of our knowledge - depends on our cognitive constitution and the epistemic standards appropriate to it [--] so that what these objects are is in part dependent on the structure of our perspectives [--- ${ }^{60}$

In what follows I will examine the tenability of commonsense realism as a rejection of metaphysical realism. The principal objection to the commonsense realist reading centers round the view that it is incompatible with Nietzsche's anti-metaphysical realism. In this section I will endeavour to show that these two positions are in fact compatible. I am interested in commonsense realism to the extent that it can be

59 Michael Williams, Groundless Belief: An Essay on the Possibility of Epistemology, (Princeton: Princeton University Press, 1999), pp. 28-29.

${ }^{60}$ R. Lanier Anderson, "Overcoming Charity: The Case of Maudemarie Clark's Nietzsche on Truth and Philosophy" in Nietzsche-Studien, 1996, p. 327. 
equated with internal realism as I have defined it so far. I will begin, then, by articulating the debate between the commonsense realists and their opponents.

Clark defines common sense realism as the view that the world is "independent of the actual existence of knowers and representations". ${ }^{61}$ This is a position that has met with some opposition from such critics as Peter Poellner and R.

Lanier Anderson. Poellner contends that Clark's definition of common sense realism entails metaphysical realism:

Pace Clark [---] according to Nietzsche, accepting 'common sense realism' commits one, whether one realizes it or not, to what Clark calls 'metaphysical realism', i.e. to precisely the view that there are entities with properties (namely non-subject-implying ones) which are inconceivable, and a fortiori unknowable, by 'any possible [conceivable] knower'. ${ }^{2}$

However, Clark claims that commonsense realism would entail metaphysical realism if she took metaphysical realism to mean only that the world has an existence independent of knowers and representations. She argues that this is not all she takes metaphysical realism to mean. She contends that metaphysical realism entails, contrary to Poellner's claim, that the world is inaccessible and unknowable to human knowers or beings with the same cognitive interests as ourselves. ${ }^{63}$ In an attempt to clarify the issue she distinguishes between what she calls a metaphysical realist notion of substance and our ordinary notion of substance. The metaphysical realist notion of substance involves "the concept of an unchanging substrate that underlies all change", ${ }^{64}$ whilst our ordinary notion maintains that:

\footnotetext{
${ }^{61}$ Clark, Nietzsche on Truth and Philosophy, p. 45.

${ }^{62}$ Poellner, Nietzsche and Metaphysics, p. 89n.

${ }^{63}$ Clark agrees with Poellner's claim that it is doubtful whether anyone has ever held the view that the world is independent of any conceivable knower. Rather, Clark claims that metaphysical realism entails that the world is inaccessible to the human knower. (See Clark, Nietzsche on Truth and Philosophy, p. 47).

64 Ibid., p. 107.
} 
A thing in this ordinary sense remains the "same thing" when we can attribute to it spatiotemporal continuity under the same concept, even though the thing itself will have changed in the process. ${ }^{65}$

Lanier Anderson objects to Clark's distinction claiming that our ordinary notion of substance entails the metaphysical realist notion. However, Clark argues, correctly I believe, that this is not the case because the metaphysical realist notion of world, as understood by Nietzsche, is of a "second real world" and therefore of something radically different from the empirical world with which we are familiar. ${ }^{67}$ Thus Clark claims that even acquiring information that is in principle inaccessible to human knowers would not allow us access to the metaphysical world, as Nietzsche understands it. Such inaccessible knowledge would prove, Clark maintains, cognitively useful to us (thus satisfying our cognitive interests to a greater extent), whereas it is Nietzsche's contention in Human, All Too Human that metaphysical realist knowledge would be unable to provide answers that we would find cognitively useful. Thus metaphysical realist knowledge would be unrecognizable to us to the extent that it would be independent of our cognitive interests and therefore unintelligible to us. On the basis of this, according to Clark, Nietzsche construes metaphysical realist knowledge as recognition independent. The distinction between the two notions of substance can be seen with greater clarity if we consider Nietzsche's rejection of metaphysical realism as a rejection of the Aristotelian understanding of substance as substratum. Substance, understood in this way, denotes an unconditioned self-identical substrate underlying the changing qualities of a thing.

\footnotetext{
${ }^{65}$ Ibid.

${ }^{66}$ Nietzsche, HAH, 5.

${ }^{67}$ Clark, Nietzsche on Truth and Philosophy, p. 98.
} 
Peter Poellner articulates the manner in which rejection of this conception of substance can give way to our ordinary notion of substance:

[---] objectivity [---] can be vouchsafed without having recourse to such problematic notions by thinking of the object as simply a bundle of qualities subject-independently co-instantiated at particular times and places. If the object is to be thought of as a relatively enduring one - as many physical things usually are - further specifications need of course to be added, such as spatial and qualitative continuity of its successive temporal phases. ${ }^{68}$

In this way it seems possible to both reject the metaphysical realist idea of substance and retain the independent existence of the world. However, Poellner contends that the acceptance of this position still commits one to metaphysical realism. It does this because metaphysical realism, according to him, comprises the idea that reality is extra-perspectival. I addressed this objection earlier when I rejected the claim that extra-perspectival properties entail metaphysical realism. Let me return to this argument. The claim that reality is extra-perspectival means that reality is metaphysically non-reducible to our perspectives. It seems to me that Poellner's objection is problematic only if we accept a constitutive reading of perspectivism in a similar manner to the one that we witnessed in the physical synthesis view. Such a reading adopts the view that perspectives constitute objects. However, a rehearsal of my earlier reading of perspectivism as an epistemic anti-foundationalist doctrine shows how we can avoid this dilemma. According to this view perspectives are the conditions of the activity of knowing. They do not, however, constitute what is known. The extra-perspectival properties of the world alluded to by Poellner can be accommodated by this reading without committing Nietzsche to metaphysical realism as I have construed it so far. This can be achieved by considering extra-perspectival

${ }^{68}$ Poellner, Nietzsche and Metaphysics, p. 33. 
properties as independent of our cognitive capacities but not independent of our cognitive interests. This implies that those properties that transcend our particular interests/perspectives cannot cast our present beliefs into massive error. It seems, then, that Nietzsche can retain the idea of independent existence without accepting metaphysical realism by denying that truth is recognition independent. Thus this version of anti-metaphysical realism allows Nietzsche to retain our ordinary notion of substance without rendering it incompatible with his perspectivism. I am now in a position to articulate Nietzsche's anti-metaphysical realism as an internal realism whereby truth is a matter of contextualist justification subject to a realist constraint. Nietzsche's internal realism thus reins in the metaphysical excesses of the Kantian thing-in-itself and, in so doing, establishes a reconnection between the issues of justification and truth.

Having established this I will now embark upon my examination of Clark's view that Nietzsche can only be said to embrace this position in his final six books. Clark's argument centers round the claim, erroneous in my view, that Nietzsche abandons the language of the falsification thesis in these last books. This rejection of the falsification thesis facilitates, in Clark's estimation, Nietzsche's rejection of the counterintuitive implications attributed to him by Lanier Anderson's physical synthesis reading. It is important for the present analysis that I address this issue. If Clark's assessment regarding the abandonment of the falsification thesis is incorrect then it prejudices the commonsense realist reading in favour of the counterintuitive one. In the final section, however, I will endeavour to show that Nietzsche's internal realist position can be maintained despite the collapse of Clark's claim, and thus that 
this reading is implied throughout what Clark calls Nietzsche's "middle" period. I will proceed then by adumbrating Clark's argument.

\subsection{Nietzsche and the Falsification Thesis}

Clark argues that Nietzsche adopts a commonsense realist approach in his last six books where, she maintains, he rejects his earlier claim that our knowledge is illusory. She founds this argument on her view that Nietzsche's published writings can be divided into three distinct periods. She argues that in "On Truth and Lies in a Nonmoral Sense", Nietzsche accepted both the metaphysical correspondence theory of truth and a version of Schopenhauer's representationalism. According to Clark, Nietzsche accepted the existence of the thing-in-itself in this essay but denied that our human knowledge is adequate to the nature of reality as it is in itself. However, she argues that Nietzsche alters this view in his "middle" period, which is said to span from Human, All Too Human to Beyond Good and Evil. She argues that in this middle period Nietzsche rejects the thing-in-itself but retains the representational view of knowledge. ${ }^{69}$ Clark maintains that, under the influence of Schopenhauer, Nietzsche retains the falsification thesis and the view that our knowledge is reducible to representations. Moreover, she suggests that Nietzsche's retention of the falsification thesis in The Gay Science commits him to the view that our

\footnotetext{
${ }^{69}$ Interestingly, Clark has since altered her view and she now dates Nietzsche's "late" period from HAH. For this, see Clark, "On Knowledge, Truth and Value", in Christopher Janaway (ed.), Willing and Nothingness: Schopenhauer as Nietzsche's Educator, (Oxford: Clarendon Press, 1998), p. 52. However, since I am really concerned with the broader philosophical issues rather than Clark per se in the above examination, I will not delve into the implications of this change of mind. However, it should be remembered that this thesis has adopted the view that there is a high degree of continuity to Nietzsche's thought. This will be seen more readily in chapter three. Such continuity casts suspicion on the validity of dividing Nietzsche's writings into tidy compartments.
} 
commonsense beliefs are illusory or false. This characterization of our beliefs as illusory results, according to Clark, from, what she considers to be Nietzsche's simultaneous commitment to subjective idealism and phenomenalism in his middle period. Thus Clark contends that Nietzsche's appeal to "appearance" in this period implies two incompatible positions. Firstly, she claims that his appeal to appearance in The Gay Science, 54, in the light of his rejection of the cogency of the thing-initself, entails subjective idealism. Subjective idealism is here understood as the view that reality is reducible to our representations. I will cite the relevant passage for the convenience of the reader:

What is "appearance" for me now? Certainly not the opposite of some essence; what could I say about any essence except to name the attributes of its appearance! Certainly not a dead mask that one could place on an unknown $x$ or remove from it. ${ }^{70}$

Secondly, Clark argues that Nietzsche's appeal to appearance and his endorsement of the falsification thesis in The Gay Science commits him to the physical synthesis view outlined earlier. Clark thus maintains that in this "middle" period Nietzsche fails to recognize that his rejection of the thing-in-itself releases his common sense and scientific beliefs from the title "illusion" thus allowing them to bear the title "truth" in a non metaphysical realist sense. However, Clark argues that in the final period Nietzsche frees himself from the shackles of Schopenhauerianism where he combines his rejection of the thing-in-itself with the rejection of the falsification thesis to give way to a commonsense realism. She contends that Nietzsche's rejection of the falsification thesis supports her claim that he has moved from the "appearance" talk of The Gay Science and Beyond Good and Evil to the common sense realism of 
On the Genealogy of Morality onwards. Let me probe this a little. In so doing, I will be concerned to address Clark's argument that Nietzsche, in his last six books, rejects the falsification thesis and subsequently moves from both phenomenalism and subjective idealism to commonsense realism. Here I will argue that Clark's claim that Nietzsche abandons the language of falsification in his last six books is mistaken. However, I will endeavour to show that the commonsense realist reading can nevertheless be upheld.

Clark's argument is principally founded on her belief that Nietzsche abandons the falsification thesis in his final six books. By abandoning the position that our beliefs may be radically, in the sense of globally, false Clark maintains that Nietzsche abandons the Schopenhauerian claim that our empirical beliefs are mere illusions. However, by appealing to an argument put forward by Lanier Anderson and to Nietzsche's texts themselves we can see that there is evidence to suggest that Nietzsche, contrary to Clark's claim, never abandoned the language of falsification. Firstly, in On the Genealogy of Morality, which Clark maintains signals Nietzsche's rejection of the falsification thesis, he continues to employ the language of falsification. $^{\text {"l }}$ In GM III, 24 Nietzsche identifies interpretation with falsification. This coupled with his claim in GM III, 12 that interpretation is an essential component of knowledge suggests, according to Lanier Anderson, that "all our

\footnotetext{
${ }^{70}$ Nietzsche, GS, 54.

${ }^{71}$ From this point onwards I will use abbreviations when referring to Nietzsche's texts. The main purpose of the abbreviations will be to avoid cluttering the text. The following are the abbreviations that I will employ:

GM: On the Genealogy of Morality.

BGE: Beyond Good and Evil.

GS: The Gay Science.
} 
theoretical beliefs are infected by endemic falsification". ${ }^{72}$ Secondly, Clark maintains that the passage in Twilight of the Idols entitled "How the Real World Finally Became a Fable" provides evidence that Nietzsche, at this stage of his career has abandoned the falsification thesis and the dual implications (phenomenalist and idealist) of his appeal to appearances. In support of this claim Clark maintains that Nietzsche distinguishes between steps five and six of the aforementioned passage. I will cite steps five and six for the convenience of the reader:

5. The 'real' world - an idea with no further use, no longer even an obligation - an idea become useless, superfluous, therefore a refuted idea: let us do away with it!

(Broad daylight; breakfast; return of bons sens and cheerfulness; Plato's shameful blush; din from all free spirits.)

6. The real world - we have done away with it: what world was left? The apparent one, perhaps? - But no! with the real world we have also done away with the apparent one!

(Noon: moment of the shortest shadow; end of the longest error; pinnacle of humanity; INCIPIT ZARATHUSTRA) ${ }^{\mathbf{7 3}}$

According to Clark, stage five represents Nietzsche's view up to and including book five of GS (that is, a simultaneous commitment to both phenomenalism and subjective idealism), whilst stage six is said to represent Nietzsche's commonsense realist view from GM onwards. Step six represents, in Clark's view, a rejection of the falsification thesis because "there our empirical access to the world is no longer stigmatized as 'merely apparent", ${ }^{74}$ However, Lanier Anderson argues, correctly in my view, that steps five and six, contrary to Clark's claim that they are separate positions, may in fact be construed as two aspects of just one position. Lanier Anderson maintains that Nietzsche's use of two steps to make one point is not

\footnotetext{
${ }^{72}$ Lanier Anderson, "Overcoming Charity: The Case of Maudemarie Clark's Nietzsche on Truth and Philosophy", p. 317.

${ }^{73}$ Nietzsche, Twilight, IV.

${ }^{74}$ Lanier Anderson, "Overcoming Charity: The Case of Maudemarie Clark's Nietzsche on Truth and Philosophy", p. 320.
} 
surprising within the overall structure of his outline of the history of philosophy in Twilight of the Idols. For the initial two steps represent, in Nietzsche's view, two aspects of just one metaphysical position, viz., Platonism/Christianity. According to the assessment proffered by Lanier Anderson, the crucial move in Nietzsche's strategy in his outline of the history of philosophy, and which also appears in GS, 354 (which belongs, in Clark's view to Nietzsche's middle period), is the rejection of the "true" world. With this rejection the justification for denigrating the empirical world as apparent should be removed. Furthermore, the removal of the appearance/reality distinction should, in turn, entail a rejection of the language of falsification. However, Lanier Anderson argues, convincingly I believe, that Nietzsche's conclusion that "with the true world we have also abandoned the apparent one", does not entail an implicit rejection of the language of the falsification thesis:

[--] in The Gay Science, the point of stage 6 ("It is even less the opposition of 'thing-in-itself" and appearance [that concerns me]; for we do not 'know' nearly enough to be entitled to any such distinction. We simply lack any organ for 'knowledge', for 'truth"') occurs within three sentences of a canonical statement of the falsification thesis, in which Nietzsche insists that perspectivism involves "a great and thorough corruption, falsification, reduction to superficialities, and generalization" (GS 354). For Nietzsche, then, the conclusion of stage 6 and the falsification thesis were clearly compatible. ${ }^{75}$

Indeed, it seems that Nietzsche continues to employ the term "appearance" even after he recognizes that "no shadow of a right remains to speak here of appearance".

Considering this, it seems that we have no internal evidence to suggest that Nietzsche abandoned the falsification thesis or that he altered his view between book five of GS and $\mathrm{GM}^{77}$. It might appear, on the basis of this alone, that my internal realist

\footnotetext{
${ }^{75}$ Ibid., pp. 320-1.

${ }^{76}$ Nietzsche, WP, 567 (1888).

${ }^{77}$ Lanier Anderson suggests that Nietzsche mentions the falsification thesis in his last six books less frequently than in his earlier writings because he is less concerned with epistemological issues in his last six books. Moreover, that Nietzsche did not intend any distinction to be made between BGE and GM,
} 
interpretation of Nietzsche's philosophical project reaches an impasse. Nietzsche's claim to dissolve the appearance/reality dichotomy seems only to castigate our knowledge as "merely" apparent. In so doing, it may be argued that he reopens the problem of metaphysical realism all over again. The view that our knowledge is "merely" apparent suggests that it is radically divorced from the "true" nature of reality. Furthermore, if my interpretation of Nietzsche relapses into metaphysical realism then we reopen the question of scepticism whereby our beliefs may be radically in error. The critic who wishes to embrace this reading and suggest that Nietzsche is inconsistent in his rejection of metaphysical realism has the evidence presented above that Nietzsche never abandoned the language of falsification to fuel their claim. Let me here take time to address this issue in greater detail. In so doing, I will suggest that there are grounds to which we can appeal in order to avoid committing Nietzsche to the metaphysical realism that he aims to reject. My examination will initially involve an emphasis on the logic of Nietzsche's perspectivism and its rejection of scepticism. I will then address the issue of inconsistencies in Nietzsche's thought and suggest a way in which his retention of the language of falsification can be rendered compatible with his rejection of metaphysical realism.

Peter Poellner is one critic who wishes to bring to our attention, what he regards as, the sceptical train of thought in Nietzsche's thinking and the consequent dissociation of truth and justification. Poellner argues his case by appealing to two first edition of GM Nietzsche included a note indicating that GM was written as a "supplement and 
tenets in Nietzsche's thought. Firstly, we are invited to consider Nietzsche's claim that knowledge is possible only if we can attain the knowledge of the omniscient knower. Secondly, we are asked to consider this in the light of Nietzsche's distinction between unconditional truth and conditional truth. These terms represent both truth in itself and truth for us respectively. I will address each of these issues in turn.

Poellner cites two passages where Nietzsche equates knowledge with omniscient knowing. The first passage reads as follows:

One is unjust against Descartes if one calls his appeal to the trustworthiness of God facile. Indeed only on the assumption of a God morally constituted like us is "truth' and the quest for 'truth' something that promises success and has any sense to begin with.

The second citation maintains in a similar vein that

The intellect cannot criticize itself, simply because it cannot be compared with other species of intellect and because its capacity to know would be revealed only in the presence of 'true reality', i.e., because in order to criticize the intellect we should have to be a higher being with 'absolute knowledge ${ }^{, 78}$

Poellner interprets the above passages as putting forward the view that we can only test the truth of our beliefs through "a comparison of the perceptual data cum conceptual framework which constitute our interpretation of reality, with reality itself." ${ }^{, 79}$ Nietzsche's perspectivism, however, precludes the possibility of such a God's Eye View. This brings to our attention the aforementioned distinction between truth in itself and truth for us. According to this dichotomy our beliefs may be rationally justified but fail to be true in the sense of failing to meet the God's Eye View standard of truth. Thus according to this reading our conditionally true beliefs

clarification" of BGE. (See Lanier Anderson, "Overcoming Charity: The Case of Maudemarie Clark's Nietzsche on Truth and Philosophy, p. 322).

${ }^{78}$ Both citations are quoted from Poellner's Nietzsche and Metaphysics, pp. 58-59. The original source of the first citation is KGW, VIII, 3.36.30, whilst the second is taken from WP, 473 (1886-1887).

${ }^{79}$ Poellner, Nietzsche and Metaphysics, p. 59. 
may fail to meet the standard of metaphysical truth. Poellner identifies metaphysical truth with the point of view of Descartes' demon or the deceiving master scientist. Moreover, he argues that both Nietzsche's equation of knowledge with omniscient knowing and his claim regarding the impossibility of ever attaining to such knowledge induces a dissociation of truth and justification. In so doing, this sceptical reading of Nietzsche serves to reintroduce the separation of theory and practice that Nietzsche aims to reject. This separation is further suggested by Poellner's claim that scepticism must be understood as a possibility if we conceive of the master scientist or the demon as sharing the same cognitive interests as us. ${ }^{80}$ Poellner argues that if the deceiver shares our cognitive interests then our experiential world will remain unaltered to the extent that our experience of the world will remain uniform. Thus our beliefs about the world, he suggests, may be unknowably radically in error. However, with the clause that the deceiver may share our cognitive interests the possibility of massive error is of theoretical interest only. Our practical engagement with the world will be unaffected by this possibility. If this is the case, then, the question remains as to what sense can be made of the claim that our beliefs may nevertheless be in massive error. Rorty and others have argued that to pursue the theoretical possibility of scepticism in earnest is merely an uninteresting line of inquiry. This is a response that Nietzsche himself accepts when he states that such metaphysical knowledge would be "the most inconsequential of all knowledge". However, Poellner retorts that such claims merely evade the question and that they are not satisfactory responses to the sceptical challenge. Thus it seems that if this

${ }^{80}$ Ibid., p. 24. 
were Nietzsche's only means of defense, the charge of relapsing into metaphysical realism would remain. However, it seems to me that there are two principal reasons for rejecting the sceptical reading of Nietzsche. I will present each of these in turn. Firstly, in some places Nietzsche seems to adopt a stronger position on this issue to the one rejected by Poellner above. His rejection of the separation of theory and practice, witnessed earlier, suggests that Nietzsche aimed to reject the theoretical possibility of massive error. This is further suggested by his identification of Kant's retention of the thing-in-itself with scepticism in step three of his outline of the history of philosophy in Twilight of the Idols and Nietzsche's own rejection of Kant in steps five and six. However, we must test to see whether Nietzsche can maintain his rejection of this scepticism in the face of Poellner's challenge that the deceiver may share our cognitive interests. Earlier we witnessed Davidson's claim that the deceiver could only cast our beliefs into massive error by entering into cognitive communication with us. Davidson's argument maintained that the possibility of such communication presupposes agreement on most matters. It seems to me that the possibility of such communication is implicit in Poellner's clause that the deceiver shares our cognitive interests as shared cognitive interests presupposes shared standards of rational intelligibility. If this is the case, then, it seems that no sense can be made of the suggestion that our beliefs may nevertheless be radically in error.

Secondly, any earnest attempt to present Nietzsche as a sceptic merely serves to present him as grossly inconsistent and therefore of diminished philosophical interest. I therefore suggest that we should adopt the principle of interpretive charity

\footnotetext{
${ }^{81}$ Nietzsche, HAH, 9.
} 
when approaching Nietzsche's writings. Acceptance of this principle demands that we try to make the most philosophical sense of Nietzsche's claims and thus that we avoid, wherever possible, committing him to inconsistencies. I contend that this is not only possible with regard to Nietzsche's writings but that it is demanded by those very writings themselves. ${ }^{82}$ Thus returning to my presentation of Lanier Anderson's argument regarding Nietzsche's retention of the falsification thesis following GM, it seems that Nietzsche both criticized the appearance/reality distinction and deemed our perspectival theories to be false in the same passage. Furthermore, he continues to speak of the "apparent" world even after declaring it to be an illegitimate philosophical practice. Peter Poellner himself notes such tensions in Nietzsche's writings when he remarks that "Sometimes one can even find mutually incompatible thoughts on these issues within the same note or passage. ${ }^{n 83}$ If this is the case, (and we have seen that it is in the example of GS, 354) then it seems that Nietzsche was aware of this inconsistency. This suggested awareness implies that the inconsistency is apparent and not real. On the basis of this I must conclude that Nietzsche considers the two apparently inconsistent positions expressed in such passages as compatible. Let me suggest, then, how this apparent inconsistency can be resolved in such a way as to take proper account of Nietzsche's anti-metaphysical realist stance.

This task can be executed by questioning the meaning of Nietzsche's continued use of the language of falsification in the light of the fact that he presents many of his claims to be true. For example, in BGE, 229 he begins by promising to

\footnotetext{
${ }^{82}$ If we construe Nietzsche's writings as those of a working philosopher who seeks to encourage his readers to engage in the practice of philosophy themselves, then, we are bound to interpret Nietzsche's writings in a way that provides a positive answer to a particular philosophical problem.
} 
reveal "palpable truths" that have remained "unspoken for hundreds of years", whilst simultaneously positing a "fundamental will of the spirit, a will that is constantly drawn to appearances and surfaces". If we are not to commit Nietzsche to complete incoherence whereby he simultaneously maintains that our beliefs are false whilst presenting many of his own views as true, then we must construe Nietzsche as employing the language of falsification as a rhetorical device. By employing such a device he draws our attention to the contrast between his own perspectivism and metaphysical realism. Thus, it can arguably be claimed that Nietzsche employs the metaphysical realist correspondence theory of truth in a rhetorical way. Lanier Anderson articulates this view as follows:

It seems to me [---] that in statements of the falsification thesis, Nietzsche is simply exploiting the traditional conception of truth in order to give dramatic rhetorical expression to his view that (contra the metaphysical realist) "interpretation and subjectivity are essential to things" ${ }^{84}$

This is further suggested by Nietzsche's claim that his appeal to "appearances" is not intended to draw a strict opposition between appearance and reality as it is in itself:

Really, why should we be forced to assume that there is an essential difference between 'true' and 'false' in the first place? Isn't it enough to assume that there are degrees of apparency and, so to speak, lighter and darker shadows and hues of appearance $[--] ?^{85}$

Thus it seems that Lanier Anderson is correct when he claims that Nietzsche's use of the term "appearance" can persist even after he reaches the insight of step six of the outline of the history of philosophy (that is, that the elimination of the "true" world also entails the elimination of the merely "apparent" world"), and that it can even

\footnotetext{
${ }^{83}$ Poellner, Nietzsche and Metaphysics, p. 80.

84 Lanier Anderson, "Overcoming Charity: The case of Maudemarie Clark's Nietzsche on Truth and Philosophy", p. 326.

${ }^{85}$ Nietzsche, BGE, 34.
} 
appear along with this insight as in GS, $354 .^{86}$ Considered in this way we can avoid committing Nietzsche to a reality/appearance distinction according to which our appearances may be in error in a global sense. On this understanding, then, Nietzsche's rejection of the thing-in-itself is compatible with his rhetorical claim that our beliefs are false. Thus it would seem that Clark's claim that Nietzsche alters his position between BGE and GM is misconstrued. If this is the case then it would further seem that we cannot so conveniently distinguish between Nietzsche's appearance talk of the "middle" period and what Clark calls his commonsense realism. The only indicator that Nietzsche himself distinguished between the two positions was Clark's argument that Nietzsche abandons the language of the falsification thesis in his last six books. Now that we are free of this arbitrary division of Nietzsche's writings into distinct periods we are in a position to examine whether Nietzsche's appeal to appearance entails the simultaneous commitment to phenomenalism and subjective idealism detected by Clark, or a commonsense realism.

John Wilcox remarks, correctly in my judgement, that sometimes Nietzsche expresses himself as a common sense realist with references to commonsense objects whilst at other times he speaks the language of sense-data. This can be most readily seen in those passages where Nietzsche contrasts concepts with the reality that they aim to grasp. Sometimes the contrast is between the concept and "sensations" and "experience". For example, in GS, 112 Nietzsche contrasts our concepts with the

\footnotetext{
${ }^{86}$ To remind the reader: In GS, 354, Nietzsche claims that perspectivism entails "a great and thorough corruption, falsification, reduction to superficialities, and generalization" whilst also stating that "It is
} 
"continuum of sensation". At other times the contrast terms are normally realistic terms such as "reality", "the world" and "nature" ${ }^{87}$ Wilcox argues that we should consider the former contrast as more compatible with Nietzsche's rejection of metaphysical realism. This phenomenalist reading is more compatible with Nietzsche's philosophical project, according to Wilcox, because the latter appeal to normally realistic objects commits Nietzsche to a belief in substances which is incompatible with his rejection of metaphysical realism. This brings us back to the dilemma regarding the distinction between common sense realism and metaphysical realism. We saw that Clark defines our ordinary, non-metaphysical realist notion of substance as a commitment to ordinary middle-sized objects that undergo change but which retain a conceptual identity. Thus, it seems that if we accept Clark's distinction between our ordinary and metaphysical notions of substance, then, Nietzsche's appeal to normally realistic objects is not, contrary to Wilcox, incompatible with his rejection of metaphysical realism. Thus we are left in a position where Nietzsche would seem to speak both the language of appearance and commonsense realism without distinguishing between them. Considering this, we must question whether Nietzsche thought his appeal to both appearance and commonsense realist objects incompatible. Clark argues that Nietzsche distinguishes between, what she considers to be, his earlier commitment to phenomenalism/subjective idealism and his later commonsense realist view, when he rejects idealism (and therefore phenomenalism) in BGE, 15 in favour of commonsense realism. In this passage Nietzsche states:

even less the opposition of "thing-in-itself" and appearance [that concern me]; for we do not 'know' nearly enough to be entitled to any such distinction".

${ }^{87}$ See Nietzsche, BGE, 4, Twilight, IX.7 and WP, 610 (1884). 
In order to practise physiology with a good conscience, you have to believe that the sense organs are not phenomena in the philosophical idealist sense, for then they could not be causes! This is sensualism as a regulative hypothesis at least, if not as an heuristic principle.

What's that? And other people are actually saying that the external world is created by our sense organs? But then our body, as part of this external world, would be the creation of our sense organs! But then our very same organs would be - the creation of our sense organs! It seems to me that this is a complete reductio ad absurdum: assuming that the concept causa sui is something completely absurd. It follows that the outer world is not the creation of our sense organs -?

Of this passage Clark claims:

This passage shows Nietzsche's realization that for the purposes of giving an empirical account of human knowledge, he must presuppose the existence of real, independently existing, things: brains, sense organs, the bodies to which they belong, and the bodies with which they interact. It follows that empirical accounts cannot provide a basis for equating reality with the chaos of sensations, since they must presuppose that sense organs and bodies are real. ${ }^{88}$

However, considering that Nietzsche does not abandon the language of the falsification thesis and that he does not distinguish between what Clark calls his "middle" and "late" philosophical stance in any explicit sense, it seems that all this passage demonstrates is that Nietzsche does not accept subjective idealism in either of these "periods". It seems to me, then, that we cannot claim, as Clark's does, that Nietzsche distinguishes between his appeal to appearance in the writings before GM and common sense realism. Since Nietzsche rejects subjective idealism in BGE, 15 (what Clark calls the "middle" period), it seems that we must conclude that he thinks that common sense objects exist independently of our representations of them. Furthermore, by citing Nietzsche's Ecce Homo we can see that his continued use of the language of appearance is synonymous with a modest rather than metaphysical realism:

The 'real world' and the 'apparent world' - in plain terms: the fabricated world and reality. ${ }^{89}$

\footnotetext{
${ }^{88}$ Clark, Nietzsche on Truth and Philosophy, p. 123.

${ }^{89}$ Nietzsche, Ecce Homo, translated by R. J. Hollingdale, (London: Penguin, 1992), Foreword, 2.
} 
In the light of this discovery, it can be seen that Nietzsche's appeal to appearance is an appeal to the perspectival character of human knowing. Thus it may be argued that Nietzsche's position merely stipulates that our access to objects is mediated by our appearances/perspectival takings and not that objects are constituted in an idealist sense by these perspectives. With this theme of perspectival mediation we return to the anti-metaphysical realist requirement that truth be independent of our cognitive capacities but dependent upon our cognitive interests. This requirement stipulates that our perspectival takings on the world are not massively in error and thus that the metaphysical realist dualism of apparent world and the world as it is in itself is dissolved. Nietzsche articulates the dissolution of this dualism when he states:

The antithesis of the apparent world and the true world is reduced to the antithesis "world" and "nothing" 90

I have thus examined the manner in which Nietzsche's rejection of metaphysical realism allows for an interested conception of human knowing that is said to adequately capture the character of the world. In the next chapter I will examine the extent to which we can detect Nietzsche's internal realism emerging in the early writings. We will see that both Nietzsche's early rejection of Schopenhauer and his own view regarding the interrelation between concepts and intuitions indicate the emergence of an internal realist framework. Moreover, we will see the regulative rather than constitutive character of Nietzsche's perspectival theory of knowledge emerge in the early writings and continue in his later thought. The theme of regulative knowledge will be developed further in chapter four where we will see that Nietzsche realizes the full implications of his perspectival theory of knowledge in 
relation to his justification of the will to power metaphysics. With this in mind I will now turn to chapter three.

${ }^{90}$ Nietzsche, WP, 567 (1888). 


\section{Chapter Three}

\section{Nietzsche's Emerging Internal Realism}

\subsection{Introduction}

In this chapter I will examine Nietzsche's early writings to test the extent to which they can be seen as precursors of his later attempts to overcome the metaphysical realist opposition of self and world. I will argue that in both the published and unpublished early writings, Nietzsche initiates such an overcoming. ${ }^{1}$ In so doing, I will demonstrate that the anthropomorphism of Nietzsche's perspectival theory of knowledge that we encountered in chapter two is already present in his early writings. Moreover, I will indicate that this anthropomorphism is compatible, in these early writings, with the possibility of making objective metaphysical claims about the nature of reality.

We will see that the overcoming of the opposition of self and world in the early writings emerges from Nietzsche's deliberation on the issue and from his consideration of a number of possible responses. Thus, in what follows I will endeavour to pinpoint the range of responses that he makes to this problem. In so doing, we will see that Nietzsche's thought was only developing in these writings and that this can be felt in certain tensions that exist in the writings themselves. In his early writings, Nietzsche can be seen as a philosopher at work. By this I mean that it

\footnotetext{
'I will take Nietzsche's early writings to comprise all his writings up to 1878 . This includes both published and unpublished writings up to, but not including, Human, All Too Human. Although I will argue here for the continuity of Nietzsche's thought throughout the early and late periods, I think that it is still possible for practical reasons to distinguish between an early and late Nietzsche. As will be seen from my analysis in this chapter, Nietzsche wavers between alternative philosophical positions in the early writings. This is to be distinguished from his somewhat more confident and explicit adoption of internal realism from Human, All Too Human, 9 onwards, where he explicitly rejects the thing-initself. However, I will argue that Nietzsche sows the seeds of his later internal realist position in the early writings.
} 
can be said that in his early career Nietzsche was investigating a number of possible responses to the issue of the relationship between self and world and it is often difficult to decipher precisely which response, if any, he intended to endorse. Moreover, it is often difficult to distinguish between the different responses themselves due to the fact that he does not always indicate with any degree of transparency that he has altered his view or that he is occupying a new perspective. Therefore, Nietzsche's early writings demand a considerable degree of interpretive engagement with the texts. The principal interpretive challenge confronting the reader of these writings centers round the problem of reconciling Nietzsche's use of Kantian and Schopenhauerian language with his criticisms of these thinkers. Nietzsche's criticisms of both Kant and Schopenhauer suggest that he desires to distinguish his own philosophy from theirs. However, his rootedness in the conceptual and linguistic framework adopted by these two thinkers makes it difficult for the reader to decipher where Nietzsche has moved beyond the thought of Kant and Schopenhauer. To the extent that Nietzsche remains embedded in the thought of these thinkers he is unable to extricate himself from the appearance/reality distinction whereby our human knowledge is said to be divorced from the nature of reality. Moreover, it is sometimes argued with regard to Nietzsche's early writings, especially The Birth of Tragedy, that he endorses Schopenhauer's idea of an extra-conceptual intuition that is said to have unmediated access to the thing-in-itself. This reading commits him to dogmatic metaphysics. An alternative reading, which focuses largely on "On Truth and Lies in a Nonmoral Sense", argues that Nietzsche adopts the very scepticism that he criticizes in Kant. These two views are supported by particularly literal readings of the above 
texts. In this chapter I will demonstrate that there is further evidence, in the early writings, of the emergence of an altogether different view whereby Nietzsche suggests that our specifically human truths are adequate to reality without engaging in dogmatic metaphysics.

However, in view of the interpretive difficulties surrounding these texts, any engagement with the early writings will entail that the reader take upon themselves the responsibility of attributing to Nietzsche a particular view which, although certainly implicit in the writings, has not been explicitly differentiated from the other views. In attempting to so differentiate, my interpretive methodology will involve a degree of simplification. However this simplification will be instructive in detecting an implicit emerging internal realist solution to the problem of the opposition of self and world. This emerging solution, I will argue, fares better in resolving the problem than the other solutions considered by Nietzsche in these writings. Moreover, I will argue that internal realism is supported by the general logic of Nietzsche's early thought. We shall see that this logic militates against either a Schopenhauerian or sceptical Kantian understanding of the direction of Nietzsche's project. ${ }^{2}$

\footnotetext{
${ }^{2}$ The interpreter of these early writings is thus akin to an investigator who must piece together the various clues provided in the individual texts to weave together a unified view. In this way we cannot be passive readers of these texts but rather we must be active interpreters and constructors. Karl Jaspers articulates the position of Nietzsche's readers in the following way:

The appearance which Nietzsche's work presents can be expressed figuratively: it is as though a mountain wall had been dynamited; the rocks, already more or less shaped, convey the idea of a whole. But the building for the sake of which the dynamiting seems to have been done has not been erected. However, the fact that the work lies about like a heap of ruins does not appear to conceal its spirit from the one who happens to have found the key to the possibilities of construction; for him, many fragments fit together. (p. 3).

Thus Jaspers maintains that the "search for what is thus hidden can succeed only if the searcher proceeds as though he himself had to erect the structure which fell to pieces while Nietzsche was working on it". (p. 4). [Karl Jaspers, Nietzsche: An Introduction to the Understanding of his Philosophical Activity, translated by Charles F. Wallraff and Frederick J. Schmitz, (London: The Johns Hopkins University Press, 1997)].
} 
My examination will show that Nietzsche adopts three discernible responses to the question of the opposition of self and world. I will suggest that Nietzsche plays with a dogmatic realist, sceptical idealist and internal realist solution to the problem. The dogmatic realist solution, which Nietzsche very quickly rejects, requires that we have unmediated access to the nature of reality in itself. It further maintains that this knowledge can be employed as a standard against which our anthropomorphic truths can be tested. However, confronted by the philosophical difficulties inherent in such a view, Nietzsche adopts a second sceptical idealist solution, which denies the possibility of unmediated knowledge of reality. Rather, the sceptical idealist maintains that we only have access to our specifically anthropomorphic truths and that we cannot possibly know whether such truths correspond to the nature of things as they are in themselves. Both the dogmatic realist and the sceptical idealist solution divorce the knowing subject from the world. For both these views, the problem of overcoming the opposition of self and world centers round the difficulty of bringing one's anthropomorphic truths into harmony with a reality that stands outside and in possible opposition to these truths. The internal realist response, however, maintains that the knowing subject is immersed in the world as an evolving participator in a larger evolving whole. In so doing, it maintains that the human knower is not so divorced from reality and thus that our anthropomorphic truths are subject to a realist constraint. Furthermore, I will argue that the first two solutions are the result of Nietzsche's embeddedness, by his own admission, in a Kantian and Schopenhauerian framework. The third internal realist solution is an implicit and emerging solution, which, I will argue, Nietzsche was struggling to articulate despite his embeddedness 
in this framework. I will suggest that it is this emerging internal realism that distinguishes Nietzsche's own philosophical response to the opposition of self and world from that of his predecessors.

I will begin my examination by first looking to "On Truth and Lies in a Nonmoral Sense". This will be presented as a paradigm of the philosophical difficulties that Nietzsche was grappling with in his early career. We will see that the difficulties that Nietzsche confronts in his early career center round the issue of the knowability of the thing-in-itself. Having outlined the problems I will proceed to examine his emerging internal realist response as it is articulated in the other writings of this early period. These other writings will include The Birth of Tragedy and various unpublished fragments and notes spanning the years 1867-1878. The unpublished fragments will be introduced as a supplement to the published material.

I will thus examine the relationship between Apollo and Dionysus in The Birth of Tragedy, ${ }^{3}$ and the conception of the instinctive intellect that is developed in the early notes. In so doing, we will see that Nietzsche begins his project of overcoming the opposition of self and world by abandoning, what he regards as, the transcendentalist's extra-empirical conception of the knowing subject. In its stead Nietzsche develops an embodied affective conception of reason that combines senses with reason, and intuitions with concepts to the extent that the one is embedded in the other. In so doing, I will argue that, contrary to popular readings, the logic of

\footnotetext{
${ }^{3}$ Since the unpublished "On Truth and Lies in a Nonmoral Sense" bears the date 1873, one year after the publication of The Birth of Tragedy, it may be argued that The Birth of Tragedy cannot be construed as a response to "On Truth and Lies". However, the interpretive strategy employed in this chapter entails considering Nietzsche's early period as a whole rather than as a chronological development. I am thus interested in the philosophical problems posed by Nietzsche in this early period along with the range of solutions he offers. Within this specific interpretive framework, it is, I
} 
Nietzsche's early thinking does not advocate the idea of a pure extra-conceptual intuition of the thing-in-itself. Rather I will maintain that Nietzsche rejects, what he considers to be, the rationalist enterprise of attempting to gain pure conceptual access to reality. Thus I will argue that Nietzsche rejects the idea of pure conceptual knowledge in favour of intuitions that are already endowed with conceptual form. This will then lead to a discussion of the relationship between art and science. I will argue that Nietzsche attempts to overcome the dualism of previous metaphysics by reconciling the normative status of art with the factual pretensions of science. In so doing, we will see that his internal realism allows that our human truths communicate with the nature of reality. My discussion of the relationship between art and science will draw on some of the more mature writings, as we will see that the emerging internal realism of the early writings share a relation of continuity with the later writings. I will begin, however, by turning to Nietzsche's early-unpublished essay "On Truth and Lies in a Nonmoral Sense" in order to pinpoint some of the philosophical difficulties that Nietzsche addresses in his early writings.

\section{2 “On Truth and Lies in a Nonmoral Sense”}

Many commentators turn to "On Truth and Lies in a Nonmoral Sense" in support of their view that Nietzsche is committed to an unknowable thing-in-itself in his early writings. The unknowability of the thing-in-itself is said to commit Nietzsche to the view that our empirical truths about the world may be false. Commentators who normally avoid appealing to Nietzsche's unpublished notes feel themselves justified

believe, justified to consider The Birth of Tragedy as a response to difficulties articulated in "On Truth and Lies". For it seems to me that Nietzsche is perplexed by the same set of problems in both works. 
in appealing to this one "exception". The argument that is often employed in support of this decision is that "On Truth and Lies in a Nonmoral Sense", although unpublished in Nietzsche's lifetime, represents a unified piece of writing and is presented in a sufficiently scholarly fashion to merit our serious attention. Thus the argument is that "On Truth and Lies" manifests the type of coherency that one would expect of a published work and so may be treated as such. However, it seems to me that this "coherency" is only an apparent one and that an examination of the actual philosophical content of "On Truth and Lies" reveals a perplexed Nietzsche wavering between two incompatible views. I thus contend that the value of "On Truth and Lies" does not reside in its support of any positive doctrine Nietzsche may have held at the time but rather as an indicator of the type of problems that preoccupied him in his early career. I will argue that the significance of "On Truth and Lies" resides in its articulation of a set of philosophical difficulties rather than offering a sustained resolve or solution to these problems. In this section I will examine "On Truth and Lies" in the context of Nietzsche's struggle to overcome the opposition of self and world. We will see that Nietzsche's rejection of the possibility of unmediated access to the nature of things as they are in themselves traps him within a sceptical idealism from which no reconciliation of self and world can take place. This will then provide a platform against which Nietzsche's emerging solution to this difficulty in other writings of this period can be detected.

In "On Truth and Lies", Nietzsche adopts two distinct and mutually incompatible positions with regard to our cognitive relationship to the thing-in-itself. The first position entails the Kantian argument that "pure truth" is conceivable but 
unavailable to beings with our cognitive constitution. The second position is an agnostic one that claims that we cannot know whether our truths mirror reality but that this purely theoretical issue is insignificant to our practical concerns. In adopting the former view, Nietzsche maintains that our anthropomorphic truths are illusions and lies in the sense that they fail to correspond to reality as it is in itself. He writes:

We believe that we know something about the things themselves when we speak of trees, colors, snow, and flowers; and yet we possess nothing but metaphors for things - metaphors which correspond in no way to the original entities. ${ }^{4}$

Furthermore, Nietzsche states:

[---] all the material within and with which the man of truth, the scientist, and the philosopher later work and build, if not derived from never-never land, is at least not derived from the essence of things.

However, in putting forward this position Nietzsche comes to realize that he is adopting a dogmatic realist view that presupposes prior knowledge of the nature of the thing-in-itself. Such knowledge requires unmediated cognitive access to reality. Pure truth is, then, truth that corresponds to the thing-in-itself. With the realization that only mediated knowledge is possible, Nietzsche is forced to question this dogmatic statement of the falsification thesis. For with the rejection of the possibility of pure unmediated knowledge Nietzsche argues that we can only have anthropomorphic knowledge. He contends that pure extra-perspectival knowledge is impossible for beings with our cognitive constitution. This being so, he maintains that we can only have negative knowledge of the thing-in-itself. For if our specifically human perspective conditions our knowledge, then our knowledge of reality is mediated by the predicates that we ascribe to the empirical realm of our experience.

\footnotetext{
${ }^{4}$ Friedrich Nietzsche, "On Truth and Lies in a Nonmoral Sense", in Philosophy and Truth: Selections from Nietzsche's Notebooks of the Early 1870's, edited and translated by Daniel Breazeale, (London: Humanities Press, 1991), pp. 82-3 paragraph 1. Hereafter cited as TL.

${ }^{5}$ Nietzsche, TL, p. 83 paragraph 1.
} 
According to this view, we can construe the nature of the thing-in-itself only in opposition to the predicates that we ascribe to the empirical world. ${ }^{6}$ Confronted with these difficulties Nietzsche now adopts a second agnostic position, which maintains that we cannot know whether or not our anthropomorphic truths capture reality:

[---] we should not presume to claim that this contrast does not correspond to the essence of things: that would of course be a dogmatic assertion and, as such, would be just as indemonstrable as its opposite. ${ }^{7}$

However, Maudemarie Clark maintains that this agnostic position is not strong enough to facilitate Nietzsche's desire to deflate modern culture's over-evaluation of science and theoretical knowledge. ${ }^{8}$ Therefore, she maintains that, without any acknowledgement, Nietzsche formulates a third position. This unacknowledged third view is said to maintain that the very idea of correspondence to the thing-in-itself, of "an adequate expression of the object in the subject" is a contradictory impossibility. ${ }^{9}$ Clark, mistakenly in my view, takes this to mean that Nietzsche denies the coherence of the concept of the thing-in-itself. She argues that Nietzsche can sustain the view that our truths are illusions only if he allows for the conceivability of the thing-initself. Thus she maintains that by rejecting the conceivability of the thing-in-itself, Nietzsche rejects the view that our empirical truths are illusions. However, we can see on closer examination that Nietzsche is not actually developing a third position here

\footnotetext{
${ }^{6}$ See "On Schopenhauer", in Christopher Janaway (ed.), Willing and Nothingness: Schopenhauer as Nietzsche 's Educator, (Oxford: Clarendon, 1998), paragraph 3 p. 261ff. [Hereafter cited as OS]. See also Human, All Too Human, translated by Marion Faber and Stephen Lehmann, (London: Penguin, 1994), 9 [Hereafter cited as HAH] where Nietzsche states:

[--] there is nothing at all we could state about the metaphysical world except its differentness, a differentness inaccessible and incomprehensible to us. It would be a thing with negative qualities.

7 Nietzsche, TL, pp. 83-4 paragraph 1.

${ }^{8}$ Maudemarie Clark, "On Knowledge, Truth, and Value: Nietzsche's Debt to Schopenhauer and the Development of his Empiricism" in Janaway (ed.), Willing and Nothingness: Schopenhauer as Nietzsche's Echucator, p. 47.

${ }^{9}$ Nietzsche, TL, p. 86 paragraph 1.
} 
but that, contrary to Clark's claim, he retains the conceivability of the thing-in-itself within the context of sceptical idealism. In so doing, Nietzsche here accepts the possibility that we may not adequately represent the world. He maintains that it is possible that there is a thing-in-itself but that it remains beyond the scope of our human knowledge. Nietzsche thus proceeds to adopt what Peter Poellner terms metaphysical indifferentism ${ }^{10}$ as a supplement to his agnosticism. This is the view that there may be a way things are that transcends our capacity for knowing them, but that such knowledge would be useless knowledge for beings with our practical rather than pure cognitive interests. In adopting this position Nietzsche puts forward the view that it is only worth striving for knowledge that is practically useful. He states that "knowledge apart from its consequences" is of no interest to us:

The 'thing in itself' (which is precisely what the pure truth, apart from any of its consequences would be) is likewise something quite incomprehensible to the creator of language and something not in the least worth striving for."

Contained in Nietzsche's argument here is the view that conceivability does not coincide with metaphysical possibility. The thing-in-itself, understood as something capable of positive definition, is inconceivable to us. It is conceivable to us only as something with negative qualities. That is, it can be defined only in opposition to the world that is familiar to us and so only in terms of what it is not. However, this, in Nietzsche's view here, still allows for the metaphysical possibility that there is a thing-in-itself that differs radically from our knowledge. Implicit in this view is the idea that ultimate reality is not reducible to our knowledge. We cannot, then, as

\footnotetext{
${ }^{10}$ Peter Poellner, "Perspectival Truth" in John Richardson and Brian Leiter (eds.), Nietzsche, (Oxford: Oxford University Press, 2001), p. 111.

${ }^{11}$ Nietzsche, TL, p. 82 paragraph 1.
} 
Davidson also remarks, trim reality down to fit our epistemology. ${ }^{12}$ However, Nietzsche's acceptance of the metaphysical possibility of a thing-in-itself in "On Truth and Lies" entails that if reality is not reducible to our knowledge then it is in principle unknowable to beings with our cognitive constitution. This view thus bears strong sceptical implications. Nietzsche's indifferentist and agnostic position must, then, be construed as a response to this sceptical possibility. He claims that our empirical reality may in fact be a dream but as long as that dream is uniform and coherent there is no practical criterion to distinguish it from reality as it is in itself. ${ }^{13}$ Nietzsche also adopts a form of metaphysical indifferentism in Human, All Too Human, 9. There he allows for the theoretical possibility of pure absolute knowledge of a thing-in-itself. As in "On Truth and Lies" Nietzsche maintains there that the theoretical possibility of a thing-in-itself does not carry any practical consequences for us. He thus claims that this theoretical possibility should be of no concern to us. However, despite its similarities with "On Truth and Lies" the theoretical possibility entertained in Human, All Too Human is considerably weaker. In Human, All Too Human, 9 Nietzsche argues that once we engage in genealogical and historical inquiry whereby we trace the origin and development of a belief, we will understand that the belief in the thing-in-itself is a human invention and not really a justified claim about the nature of things. ${ }^{14}$ If the idea of the thing-in-itself as a realm of reality

12 Davidson cited by Rorty in "Realism, Anti-Realism and Pragmatism: Comments on Alston, Chisholm, Davidson, Harman and Searle" in Christopher B. Kulp (ed.), Realism/Anti-Realism and Epistemology, (Oxford: Rowman and Littlefield Publishers, 1997), p. 149.

${ }^{13}$ Nietzsche, TL, p. 87 paragraph 1 . Schopenhauer also maintains that our empirical world is similar to a dream. See Arthur Schopenhauer, The World as Will and Representation, Volume II, translated by E. F. J. Payne, (New York: Dover, 1966), p. 4. Hereafter cited as WWR, II.

${ }^{14}$ Clark states of the argument of Human, All Too Human, 9 that

He argues for the uselessness of metaphysical knowledge by offering a genealogy of the belief in a metaphysical or non-empirical world. Human beings received their first idea of a 
that lies beyond all possible human knowledge is really a hoax, then the sceptical challenge of the thing-in-itself is, in Nietzsche's view, considerably diminished. However, "On Truth and Lies", in contrast to Human, All Too Human, upholds the view that we simply cannot say whether our empirical truths represent ultimate reality. It therefore leaves the sceptical challenge of the thing-in-itself intact by allowing that it represents a coherent threat to the status of our epistemic claims. In so doing, Nietzsche lapses into the sceptical idealism for which he criticizes Kant. He does this by claiming that our knowledge is confined to the realm of appearance, the origin of which we cannot presume to guess. Moreover, he promotes that in practice the purely theoretical problem of the thing-in-itself is not an issue. In doing this, Nietzsche is guilty of the further charge that he levels at Kant. We saw in chapter two that Nietzsche charges Kant with having divorced theory from practice and thus with having set up two different standards of justification and truth. ${ }^{15}$ However, we can see that here Nietzsche is also guilty of separating theory and practice and thus of inducing an opposition between self and world.

Nietzsche's failure to overcome this opposition results from his acceptance of the sceptical idealist framework that he attributes to both Kant and Schopenhauer. This framework adopts a constitutive conception of the intellect. The intellect is said

'second world' from dreams, he claims, and later thinkers exploited the idea to explain the existence of things that seemed to have no place in the empirical world, for instance, permanent things (substance), free will, and things of a 'higher' value than the normal residents of the empirical world. When thinkers failed to find a way of explaining how such things could be part of the world accessible to empirical methods, they concluded that these methods were themselves faulty, and that the real world is accessible only to non-empirical methods. The empirical world was thereby taken to be a mere appearance or distortion of a second world, which was thereby constituted as the 'true' one. This non-empirical world was then posited as the source of things of 'higher' value - such as rationality, logic, disinterested contemplation, and altruism - which seemed inexplicable in empirical terms. (Clark, "On Knowledge, Truth and Value", p. 49). 
to constitute the empirical world of our experience by imposing pure concepts on an otherwise formless chaos of sensation. In so doing, this idealist framework separates the sensory and the rational. Nietzsche speaks of the man who "succeeds in piling up an infinitely complicated dome of concepts upon an unstable foundation, and, as it were, on running water". ${ }^{16}$ Here Nietzsche can be seen to accept a dualism of scheme and content. This dualism implies that experience is constituted by the exercise of our conceptual capacities "on some supposedly prior deliverances of receptivity"."17 Moreover, the scheme-content distinction dissociates both the concept and the intuition in a way that renders them both unfit for knowledge. With particular regard to the status of concepts it seems that concepts without intuitions are vacuous, as such concepts are unconstrained by reality. To the extent that Nietzsche can be seen to partake in the dualism of scheme and content in "On Truth and Lies" he can also be seen to perpetuate the opposition of self and world. The scheme-content divide implies that the human knower is inextricably separated from nature because our concepts are said to be unrelated to reality. Nature, Nietzsche claims, "threw away the key". 18

However, there is a suggestion in "On Truth and Lies" that Nietzsche is aware of the root of the problem of unconstrained concepts. It is suggested that the root of the difficulty lies in the relation between intuitions and concepts that is presupposed by both the dogmatic realist and the sceptical idealist. Both the dogmatic realist and the sceptical idealist, as interpreted by Nietzsche, share the common belief in pure

\footnotetext{
${ }^{15}$ Friedrich Nietzsche, The Will to Power, translated by Walter Kaufmann and R. J. Hollingdale, (New York: Vintage Books, 1968), 458 (1888). Hereafter cited as WP.

${ }^{16}$ Nietzsche, TL, p. 85 paragraph 1.

${ }^{17}$ John McDowell, Mind and World, (Cambridge: Harvard University Press, 1996), p. 10.
} 
extra-sensuous concepts. In so doing, both views entail, in Nietzsche's estimation, amnesia with regard to the true origin of our concepts. Nietzsche maintains that, contrary to the above faith in pure extra-sensuous concepts, concepts originate in and are abstracted from intuitions. He argues that concepts are abstracted from intuitions in order to draw out the general from the particular: ${ }^{19}$

Whereas each perceptual metaphor is individual and without equals and is therefore able to
elude all classification, the great edifice of concepts displays the rigid regularity of a Roman
columbarium and exhales in logic that strength and coolness which is characteristic of
mathematics. Anyone who has felt this cool breath [of logic] will hardly believe that even the
concept - which is as bony, foursquare, and transposable as a die - is nevertheless merely the
residue of a metaphor, and that the illusion which is involved in the artistic transference of a
nerve stimulus into images is, if not the mother, then the grandmother of every single
concept. Entailed in the amnesia regarding the true nature of concepts, according to Nietzsche, is the view that the arena of pure concepts is better known than perceptual knowledge and thus that the arena of pure concepts is the "regulative and imperative world". 21 The conceptual is understood, according to this view, to demarcate the realm of normative human interests. With the rejection of the possibility of unmediated knowledge, presupposed by the dogmatic realist, the normative and the factual realms are divorced. The sceptical idealist response entails that our pure concepts subsume and mold extra-conceptual intuitions. These extra-conceptual intuitions are identified

\footnotetext{
${ }^{18}$ Nietzsche, TL, p. 80 paragraph 1.

${ }^{19}$ Here Schopenhauer's understanding of the relationship between intuitions and concepts influences Nietzsche. However, it can be arguably claimed that Nietzsche sees himself as moving beyond Schopenhauer. For Schopenhauer, in Nietzsche's view, is a subjective idealist and so puts forward a constitutive conception of human knowledge, which may be radically divorced from how the world is in itself. Furthermore, Schopenhauer shares Kant's transcendentalist extra-empirical conception of the knowing subject, which is to be distinguished from the embodied willing self. However, I think it is mistake to attempt to read Nietzsche's early thought as either a direct refutation or acceptance of Schopenhauer's philosophy. Rather, it seems to me that we must see Nietzsche as an independent thinker at this stage, and thus construe any Schopenhauerian resemblances as examples of Nietzsche's appropriation of Schopenhauer.

${ }^{20}$ Nietzsche, TL, pp. 84-5 paragraph 1.

${ }^{21}$ Ibid., p. 84 paragraph 1.
} 
with the way things are in themselves, which can, however, be transformed into the world as it "ought to be" when subsumed under pure concepts. Thus with sceptical idealism we witness a split between how things are in themselves independently of our conceptual imposition, and how they appear to us under such conceptual imposition. Nietzsche's earlier agnostic and indifferentist response is of little help here. This response maintains that we should be unconcerned by the possibility that our truths may be errors for as long as this purely theoretical possibility bears no practical consequences. However, it now transpires that the acceptance of sceptical idealism, and the constitutive account of knowledge that informs such idealism, bears practical difficulties after all. For the constitutive account, in Nietzsche's view, induces a dissonance between concepts and intuitions. Moreover, this dissonance captures us in a bind. Should we place the emphasis on the conceptual we run the risk of strangling intuitions and denying them any cognitive role. Nietzsche claims that concepts furnish us with abstractions, which disallow any meaningful engagement with the world. ${ }^{22}$ However, placing the emphasis on intuitions fares no better. For intuitions without concepts disable any real practical success in the world. The world is rendered unfamiliar to the purely intuitive man to the extent that it can be said that he has no world at all. The purely intuitive man, according to Nietzsche "[---] does not understand how to learn from experience and keeps falling over and over again into the same ditch." ${ }^{23}$ Both the rational and the intuitional man are incapable of operating successfully in the world. If man is to be properly reconciled with the

\footnotetext{
${ }^{22}$ Ibid., p. 91 paragraph 2.

${ }^{23}$ Ibid. Nietzsche thus adopts a similar view to Kant who says "Thoughts without content are empty, intuitions without concepts are blind". [Immanuel Kant, Critique of Pure Reason, translated by Norman Kemp Smith (London: Macmillan Press, 1929), A51/B75].
} 
world, then, it seems that we require a unity of the conceptual and the intuitional mode of being. Although it is not entirely clear from "On Truth and Lies" alone, there is some suggestion that Nietzsche thinks that a reconciliation may be possible. Nietzsche evokes, what he terms, the "liberated intellect". ${ }^{24}$ Although he states of this liberated intellect that it "will now be guided by intuitions rather than by concepts", he also maintains that this liberated intellect will speak in "unheard-of combinations of concepts" ${ }^{25}$ From this it is suggested that the liberated intellect will engage in a creative use of concepts rather than with no concepts at all.

At the beginning of this section I argued that the significance of "On Truth and Lies" resides in its articulation of a number of philosophical difficulties that Nietzsche strives to overcome in both the early and the late writings. From the above we can see that the solution to overcoming the opposition of self and world centers round resolving the conflict between the theoretical and the practical, the normative and the factual, concepts and intuitions. Although there is some slight suggestion of the possibility of a reconciliation of the latter in "On Truth and Lies", what this resolution actually entails is far from clear. In the remainder of this chapter I will explore Nietzsche's suggested resolve to the above difficulties. I will show that Nietzsche's solution proposes a revised non-constitutive conception of the knowing intellect, and a reciprocal relationship between concepts and intuitions. Moreover we will see that Nietzsche extends such reciprocity to the relationship between art and science. In so doing, we will see that he seeks to draw together our specifically human normative ideals and the true nature of the world. I will initiate this

\footnotetext{
${ }^{24}$ Nietzsche, TL, p. 90 paragraph 2.

25 Ibid.
} 
investigation into Nietzsche's emerging positive philosophy in the early writings by now turning to The Birth of Tragedy, which, we will now see, bears the seeds of his overcoming of the opposition of self and world.

\subsection{The Birth of Tragedy}

Nietzsche describes The Birth of Tragedy as an "impossible book". In retrospect he claims that he ought to have developed a language of his own instead of "labouring [--] to express strange and new evaluations in Schopenhauerian and Kantian formulations, things which fundamentally ran counter to both the spirit and taste of Kant and Schopenhauer. ${ }^{, 26}$ In The Birth of Tragedy, then, there is a fundamental tension between what it actually says and what Nietzsche, in retrospect, claims it was struggling to say. Thus, on the one hand, we meet with an orthodox adoption of Schopenhauer accompanied by some extensive citations from Schopenhauer's writings. On the other hand, we have Nietzsche's own declaration that he was attempting to formulate a decidedly anti-Schopenhauerian thesis. In this section I will address these tensions. In so doing, I will suggest that although Nietzsche is immersed in the linguistic frameworks of both Kant and Schopenhauer, he is in the process of articulating an alternative internal realist solution to the problem of overcoming the opposition of self and world. We will see that this involves a rejection of metaphysical oppositions in general. In particular, Nietzsche's early internal realism involves overcoming the distinction between appearance and reality.

\footnotetext{
${ }^{26}$ Friedrich Nietzsche, The Birth of Tragedy and Other Writings, translated by Ronald Speirs, (Cambridge: Cambridge University Press, 1999) p. 10 paragraph 6. Hereafter cited as BT. Interestingly, in a letter to Overbeck, July 1885 , Nietzsche claims that his mature philosophy is already
} 
Moreover, we will see that it entails a rejection of Schopenhauer's view that we have unmediated extra-cognitive access to the thing-in-itself. The initial stages of my examination will involve a substantial textual component. For it is only by ascertaining Nietzsche's view that we can then proceed to examine the reasoning that informs his emerging internal realist position. With this in mind I will now proceed to examine the Birth of Tragedy.

In order to examine Nietzsche's overcoming of the opposition of self and world in this book we need to examine the relationship between Apollo and Dionysus. There are two possible readings of their relationship and its consequences for Nietzsche's desire to overcome this problem. The first reading offers no resolwe to the difficulty. It considers the two Greek gods to be in eternal conflict with one another. In so doing, it exacerbates the problem of self and world by maintaining that appearances are opposed to reality. This view is suggested by Nietzsche's claim that the empirical world of our experience may be compared to a dream. By appealing to Schopenhauer, Nietzsche claims that reality is semblance and that all people and things are phantoms or dream images. ${ }^{27}$ This would seem to commit Nietzsche to a two-world view whereby our anthropomorphic manner of knowing the world (Apollo) may be radically different from how the world is in itself (Dionysiac). ${ }^{28}$ The second view, however, attempts to offer some resolve by considering Apollo and Dionysus as equal partners whose relationship dissolves the appearance/reality

obscurely expressed in BT. (See Jaspers, Nietzsche: An Introduction to the Understanding of his Philosophical Activity, p. 55).

${ }^{27}$ Nietzsche, BT, p. 15 paragraph 1.

${ }^{28}$ Schopenhauer also experiences this problem. Schopenhauer had intended his idealism to close the gap, in Berkeleian fashion, between representations and objects. However, Schopenhauer's constitutive account of knowledge coupled with his comparison of the empirical world to a dream or illusion 
distinction. This view is particularly encouraged by an unpublished preface to The Birth of Tragedy. Here Nietzsche claims that he aims to put forward a one-world view that overcomes the tensions between appearances and reality. ${ }^{29}$ Thus Nietzsche maintains that his aim in this book is to overcome the appearance/reality distinction and a world-view founded upon the juxtaposition of opposites. Moreover in The Birth of Tragedy Nietzsche claims that he is interested in the art of comfort in this world as opposed to another unknowable metaphysical realm. ${ }^{30}$ We must therefore look closely at what Nietzsche means by semblance. In so doing, we will see that Nietzsche's understanding of what constitutes an appearance is a complex idea and is not to be understood as the opposite of reality. We will thus see that for Nietzsche there is no opposite of appearance to the extent that what we have hitherto called appearance and reality are now dissolved into one another. I will begin to address this issue by turning to an examination of the relationship between the Apolline and the Dionysiac in Nietzsche's early writings.

Nietzsche articulates the relationship between the Apolline and the Dionysiac on three principal levels. The three levels are, as Silk and Stern point out, ${ }^{31}$ the psychological, the aesthetic and the metaphysical. Nietzsche's three tiered interest in the two Greek gods, Apollo and Dionysus, are so intimately intertwined as to be almost indistinguishable. However, in the interests of clarity and our attempt to isolate Nietzsche's treatment of the metaphysical issue of appearance and reality in The Birth of Tragedy, I will attempt to distinguish between the levels.

arguably re-opens this gap. See Arthur Schopenhauer, The World as Will and Representation, I, translated by E. F. J. Payne (New York: Dover, 1966), p. 34-5. Hereafter cited as WWR, I.

${ }^{29}$ Nietzsche, WP, 853 (1886).

${ }^{30}$ Nietzsche, BT, p. 12 paragraph 7. 
On the psychological level, the Apolline and the Dionysiac represent a plurality of drives through which we relate to the world. Silk and Stern describe the Apolline and the Dionysiac on the level of psychology as "[---] creative human impulses, Triebe, under which are subsumed modes of perceiving, experiencing, expressing and responding to reality."32 As a psychological impulse the Apolline experiences the world as ordered and stable whilst the Dionysiac experiences the dissolution of this order and thus experiences the world as in flux.

The aesthetic understanding of the two Greek gods is founded on the psychological analysis. As aesthetic criteria, the Apolline and the Dionysiac are said to represent "cultural tendencies" which express the psychological impulses. Thus sculpture is characterized as Apolline and music as Dionysiac. Sculpture represents Apolline order whilst music expresses Dionysiac flux. The contrast here is between dream and intoxication respectively.

It is at the metaphysical level that we enter into some controversy regarding the role that each of the gods play and their relationship to one another. Initially in The Birth of Tragedy Nietzsche presents the Apolline and the Dionysiac in terms of an opposition. He traces the etymological origin of Apollo as the god of light, the "luminous one" (der Scheinende), ${ }^{33}$ which serves to emphasize its apparent nature. He employs Schopenhauer's metaphor of the veil of Maya to describe the Apolline as the cognitive forms of individuation. The Apolline is thus said to be responsible for our cognitive acquaintance with the individuated forms of the empirical world.

\footnotetext{
${ }^{31}$ M. S. Silk and J. P Stern, Nietzsche on Tragedy, (Cambridge: Cambridge University Press, 1981), p. 288.

${ }^{32}$ Ibid

${ }^{33}$ Nietzsche, BT p. 16 paragraph 1.
} 
However, Nietzsche also suggests that Apolline appearances (Erscheinungen) are in fact illusions (Scheine) because they do not faithfully correspond to the Dionysiac. The Dionysiac is presented as the primal "oneness" that lies behind the Apolline world of empirical illusion. ${ }^{34}$ In so presenting the two impulses Nietzsche sees them as representing appearance and reality respectively. ${ }^{35}$ Thus he identifies Dionysus with nature and truth while equating the Apolline with culture and illusion:

The contrast between this genuine truth of nature and the cultural lie which pretends to be the only reality is like the contrast between the eternal core of things, the thing-in-itself, and the entire world of phenomena; and just as tragedy, with its metaphysical solace, points to the eternal life of that core of being despite the constant destruction of the phenomenal world, the symbolism of the chorus of satyrs is in itself a metaphorical expression of that original relationship between thing-in-itself and phenomenon. (Erscheimungswelt)

Here Nietzsche articulates the relationship between the Apolline and the Dionysiac in terms of an appearance/reality dualism that he must necessarily overcome if he is to reconcile self and world.

However, it seems to me that this reading can only be upheld if we take a particular literal and simplified reading of the The Birth of Tragedy. Such a reading does not consider fully Nietzsche's own claims that he was struggling to articulate a non-Schopenhauerian and non-Kantian thesis, and his explicit declaration that he is attempting to overcome the opposition between reality and appearances. If we allow these comments to direct our reading of this book we will find that Nietzsche is engaging in something far more complex than a simple opposition between the two Greek gods. In the remainder of this section I will attempt to look deeper behind the apparent language of opposition. In so doing, we will find that although Nietzsche

\footnotetext{
${ }^{34}$ Ibid., p. 19 paragraph 2.

${ }^{35}$ Ibid.

${ }^{36}$ Ibid., pp. 41-2 paragraph 8.
} 
articulates his view in the language of opposites he has something quite different in mind. This can be initially achieved by examining in closer detail the relationship that Nietzsche sets up between the Apolline and the Dionysiac. The relationship between the two Greek gods can only be said to be an oppositional one if either one of them is granted supremacy over the other. If Nietzsche posits them as equal partners, however, we must conclude that The Birth of Tragedy does not endorse an appearance/reality distinction. In what follows, then, I will endeavor to demonstrate that Nietzsche posits the two gods as equal partners rather than as a pair of irreconcilable opposites.

That the Apolline and the Dionysiac do not represent an opposition can be seen from Nietzsche's thesis regarding the interdependency of the Dionysiac and the Apolline. He argues that the two impulses mutually limit and define one another. $\mathrm{He}$ states that the Apolline is intimately related to the Dionysiac:

The Apolline Greek, too, felt the effect aroused by the Dionysiac to be 'Titanic' and 'barbaric'; at the same time he could not conceal from himself the fact that he too was related inwardly to those overthrown Titans and heroes. ${ }^{37}$

Just as much as the Apolline requires the Dionysiac so too, in Nietzsche's view, does the Dionysiac require the Apolline. He states:

The more 1 become aware of those all-powerful artistic drives in nature, and of a fervent longing in them for semblance, for their redemption and release in semblance, the more I feel myself driven to the metaphysical assumption that that which truly exists, the eternally suffering and contradictory, primordial unity, simultaneously needs, for its constant release and redemption, the ecstatic vision, intensely pleasurable semblance. ${ }^{38}$

From the above we can see that Nietzsche articulates the relationship between the Apolline and the Dionysiac as one of "reciprocal necessity". 39 It is difficult to

\footnotetext{
${ }^{37}$ Ibid., p. 27, paragraph 4.

38 Ibid., p. 26 paragraph 4.

${ }^{39}$ Ibid. Nietzsche describes the relationship between the Apolline and the Dionysiac as a "mysterious marriage" (BT, p. 28 paragraph 4) and a "mysterious unity" (BT p. 28 paragraph 5).
} 
ascertain the logic behind Nietzsche's thought from an examination of the Birth of

Tragedy alone. ${ }^{40}$ However, if we consider Nietzsche's view that the Apolline and the

Dionysiac reciprocate one another in the context of some comments that he makes in

"On Schopenhauer" his reasoning can be brought into focus a little more clearly. In

this context, Nietzsche's view that the Apolline and the Dionysiac are reciprocal

partners can be understood as partaking in his aim to overcome the unknowable

thing-in-itself. For it is this idea that results in an irreconcilable opposition of self and

world. If this opposition is to be properly overcome, Nietzsche suggests, our

knowledge must be brought into closer contact with the nature of reality. Kant had

put forward the idea that things-in-themselves were thinkable but not knowable.

However, Nietzsche maintains that the thinkability of the thing-in-itself does not

render the concept any less meaningless. ${ }^{41}$ The thing-in-itself is meaningless,

according to Nietzsche in "On Schopenhauer", because it is not capable of a positive

${ }^{40}$ Nietzsche attempts to explicate the nature of the unity of the Apolline and the Dionysiac by turning to an examination of lyric poetry. Music, Nietzsche maintains, "produces a copy of the primordial unity" (BT, p. 30 paragraph 5) which he describes as a repetition of the world and a second copy of it. However, music must be "represented". Under the influence of the Apolline, music becomes visible in a symbolic dream image:

The image-less and concept-less reflection of the original pain in music, with its release and redemption in semblance, now generates a second reflection, [my italics] a single symbolic likeness (Gleichnis) or exemplum. The artist has already given up his subjectivity in the Dionysiac process; the image which now shows him his unity with the heart of the world is a dream scene which gives sensuous expression to the primordial contradiction and pain, along with its primal lust for and pleasure in semblance. (Ibid.)

However, passages such as this one are sometimes interpreted in the Nietzsche literature as putting forward the view that aesthetic experience involves the overcoming of our subjective attachments in favour of a spectator approach to the question of knowledge or insight into the ultimate nature of reality. I think that the argument provided in this chapter suggests an alternative understanding. When Nietzsche claims in this passage that the artist overcomes his subjectivity I take him to mean that it is possible to attain objective knowledge of reality. That Nietzsche does not mean to suggest that such objective knowledge involves overcoming the "subjective" forms of cognition can be seen from his further claim that such "Dionysiac" knowledge is not independent of "semblance" or the Apolline forms of our cognition. In this way it can be seen that Nietzsche is putting forward a different view from that of Schopenhauer.

${ }_{41}$ See Friedrich Nietzsche, Beyond Good and Evil, translated by Marion Faber, (Oxford: Oxford University Press, 1998), 2, [Hereafter cited as BGE]. See also HAH, 1. In both these passages Nietzsche rejects, what he terms, the metaphysics of opposites. 
definition. The difference between Nietzsche's argument here and the indifferentist one witnessed earlier is that here he argues that the lack of a positive definition means that the thing-in-itself cannot be clearly distinguished from the empirical world of our experience. Nietzsche maintains that the thing-in-itself can only be defined negatively by conceiving it in opposition to the predicates that we ascribe to the empirical world. The thing-in-itself is thus "something lying wholly outside the sphere of cognition, a list of negative properties [---]" ${ }^{42}$ In response to what he sees as Schopenhauer's demand for a positive definition, however, Nietzsche maintains that a positive definition can be had, only by ascribing the very same predicates that we ascribe to experience to the thing-in-itself. To do so, however, is to fail to distinguish between the empirical world and the thing-in-itself at all. Nietzsche states:

[---] Schopenhauer requires that something which can never be an object should nevertheless be thought of objectively. But on this route we can reach only an apparent objectivity, given that a totally obscure, inconceivable $X$ is being decked out, as if in brightly coloured clothes, with predicates drawn from a world alien to it, the world of appearance. Subsequently we are required to regard the surrounding clothes - the predicates - as the thing in itself: that is the meaning of the sentence 'if it is nevertheless to be thought of objectively, it must borrow name and concept from an object.' Thus 'because it must be so', the concept 'thing in itself' is secretly moved aside and another pressed into our hands in its stead. ${ }^{43}$

The concept of the thing-in-itself, according to Nietzsche, merely engages in a dubious metaphysics of opposites "despite the fact that between thing in itself and

\footnotetext{
${ }^{42}$ Nietzsche, OS, paragraph 3 p. 262.

In "On Truth and Lies" Nietzsche argued that, as something capable of negative definition, the thing-in-itself could be defended as a metaphysical possibility to which we should be indifferent for as long as it makes no practical difference to us. However, in OS, Nietzsche rejects the meaningfulness of this understanding of possibility. He states:

There can be a thing in itself yet only in the sense that in the region of transcendence everything is possible that ever was hatched in a philosopher's brain. This possible thing in itself can be the will: a possibility which, arising as it does out of the connection of two possibilities, is only the negative power of the first possibility, in other words a strong move towards the other pole, that of impossibility. (OS, paragraph 2 p. 261).

${ }^{43}$ Ibid., paragraph 3 p. 262.
} 
appearance not even the concept of opposition has any meaning" ${ }^{44}$ In "Schopenhauer

as Educator" Nietzsche praises Schopenhauer's attempt to reconcile knowledge and

Being or to overcome the opposition of self and world. ${ }^{45}$ Although Schopenhauer accepts the dualistic framework of the Kantian distinction between thing-in-itself and appearance, he attempts to overcome the agnosticism of Kant's appeal to the thing-initself by adopting the view that the thing-in-itself is intuitable as the Will. However, in "On Schopenhauer" Nietzsche criticizes this aspect of Schopenhauer's programme. By claiming that we can intuit the thing-in-itself as Will, Schopenhauer means that our knowledge of the Will is not subject dependent. It is thus said to be independent of the forms of our knowledge, which are the forms of the Understanding (space and causality). Thus Schopenhauer, in Nietzsche's view, attempts to resolve the Kantian problem by bypassing the cognitive subject altogether in favour of unmediated intuitive access to the nature of things in themselves. From this it seems that Schopenhauer does not resolve the opposition of self and world. Rather, Schopenhauer, in Nietzsche's view, merely retreats to an extra-cognitive standpoint. ${ }^{46}$ In this way, it can be arguably claimed that Schopenhauer does not even address the

\footnotetext{
${ }^{44}$ Ibid., paragraph 2 p. 260.

${ }^{45}$ Friedrich Nietzsche, "Schopenhauer as Educator", 3 in Untimely Meditations, translated by R. J. Hollingdale, (Cambridge: Cambridge University Press, 1994).

${ }^{46}$ It may be argued that Schopenhauer, contrary to the claim made here, does allow that we have cognition of the true nature of things-in-themselves in aesthetic experience. Moreover, it may be argued that Schopenhauer does not bypass the cognitive subject but rather that aesthetic experience involves, for him, "nothing but the Idea and the pure subject of knowing". [Schopenhauer cited by Patrick Gardiner, Schopenhauer, (Middlesex: Penguin, 1963) p. 204]. However, this objection carries little consequence for my argument. For Schopenhauer's account of aesthetic experience involves, as Patrick Gardiner explains, the view that "the forms of consciousness in which the sense of oneself as a persisting separate individual vanishes and where the ordinary distinction between percipient and perceived seems to lose hold." (Gardiner, Schopenhauer, p. 202). To the extent, then, that Schopenhauer thinks that an intuition of the nature of things as they are in themselves involves overcoming the forms of empirical knowledge, it seems correct to say that he bypasses the cognitive subject. The subject of aesthetic experience evoked by Schopenhauer is of the "spectatorial" (Gardiner, Schopenhauer, p. 201) kind that Nietzsche does not, in my view, support.
} 
Kantian dilemma. This dilemma centers round the difficulty in reconciling human cognition with the nature of reality. Furthermore, as we have seen, Nietzsche argues that Schopenhauer can only begin to describe the Will as thing-in-itself by employing the forms of the Understanding. ${ }^{47}$ In so doing, Nietzsche draws our attention to his own view regarding the impossibility of immediate knowledge and his further contention that we cannot bypass the cognitive subject in the way that Schopenhauer suggests. The reciprocal relationship between the Dionysiac and the Apolline is arguably designed to make just this point. In presenting the two gods as reciprocal partners Nietzsche draws our attention to his view that knowledge of reality must be mediated and conditioned by the forms of our knowing. He thus suggests that the Dionysiac process whereby subject and object become one must be articulated in the language of Apollo. In this way Nietzsche attempts to bring both the subject and the object of knowledge into communication with one another.

However, there are still some passages in The Birth of Tragedy where Nietzsche seems to almost retract his view that the Apolline and the Dionysiac are interdependent. I will cite some of these passages in order to suggest an alternative reading of them. For example, Nietzsche writes:

[--] whereas lyric poetry depends utterly on the spirit of music, music itself, in its absolute sovereignty, has no need at all of images and concepts but merely tolerates them as an accompaniment. $^{48}$

Furthermore, Nietzsche maintains that music symbolizes a sphere that lies above and beyond all appearances. ${ }^{49}$ Here we are confronted by one of the difficulties and

\footnotetext{
${ }^{47}$ In a supplementary chapter to WWR, II, p. 197 Schopenhauer modifies his claim regarding the subject independent nature of our intuition of the will. Here he argues that our knowledge of the will, although independent of the forms of space and causality, is not independent of time. He argues that we can know the will "only in its successive individual acts, not as a whole, in and by itself".

${ }^{48}$ Nietzsche, BT, p. 36 paragraph 6.
} 
tensions inherent in The Birth of Tragedy. On the one hand, Nietzsche maintains that the Apolline and the Dionysiac are interdependent. On the other hand, he suggests in the above citation that Dionysiac music is independent of concepts and language. However, there are, I believe, two possible responses that can be made here that will both alleviate this tension and further support my argument that the Apolline and the Dionysiac are not opposed to each other in The Birth of Tragedy. Firstly, we can repeat the point that at this stage of his career and by his own admission, Nietzsche is very much embedded in the philosophy of Schopenhauer and thus that the language of Schopenhauer's writings direct Nietzsche's thought here. Secondly, however, a non-conflicting reading of these passages can be suggested by considering Schopenhauer's view of concepts. Under the influence of Schopenhauer, Nietzsche conceived the Apolline as the cognitive forms of space, time and causality. According to Schopenhauer these are the non-conceptual forms of the Understanding which are to be contrasted with the pure conceptual forms of the faculty of Reason. Schopenhauer had criticized Kant's pure concepts of the Understanding ${ }^{50}$ claiming that although they are necessary for the communication of thought they are not necessary for, and can indeed hinder, experience and action. In making this distinction Schopenhauer is critical of what he conceives as Kant's commitment to the notion of explicit judgement. Explicit judgement entails the conscious and explicit appeal to a concept as a rule of action, which is extrinsic to the action itself. He states that "in the case of billiards-playing, fencing, tuning an instrument, or singing,

\footnotetext{
49 lbid.

${ }^{\text {so }}$ Nietzsche himself does not seem to distinguish between the Understanding and Reason using the latter term to stand for both. See WP, $530(1883-1888)$ where he refers to the categories as the a priori
} 
knowledge of perception must directly guide activity; passage through reflection makes it uncertain, since it divides the attention, and confuses the executant." $\mathrm{He}$ states that "savages and uneducated persons, not very accustomed to thinking, perform many bodily exercises, fight with animals, shoot with bows and arrows and the like, with a certainty and rapidity never reached by the reflecting European." Thus he claims that "[---] it is of no use for me to be able to state in the abstract in degrees and minutes the angle at which I have to apply my razor, if I do not know it intuitively, in other words, if I do not know how to hold the razor." ${ }^{\text {51 }}$ Christopher Janaway explains Schopenhauer's rejection of, what he considers to be, Kant's appeal to explicit judgement as follows:

Kant held that experience requires the subsumption of sets of data under the concept cause, but Schopenhauer charges him with not making a clear distinction between what we might call 'explicit' judgement and the intuitive apprehension of causal connection. This, Schopenhauer alleges, led Kant to make a false claim, namely, that experience requires explicit judgement involving the concept cause. ${ }^{52}$

In opposition to Kant, Schopenhauer argues that the mind perceives events in the world in the medium of causality on a par with space and time, which are, for Schopenhauer, non-conceptual forms of the Understanding. However, as Janaway points out, the examples that Schopenhauer gives of extra-conceptual intuition are not necessarily extra-conceptual nor do they entail that concept use necessarily involves explicit judgement. Thus Janaway argues on Kant's behalf, and, in opposition to Schopenhauer, that

[---] since a judgement is the combining of representations in such a way as to make them capable of referring to objects, anyone who 'apprehends' the game of billiards in the ordinary

activity of pure Reason. Schopenhauer also argues that Kant does not clearly distinguish the role of the Understanding from the role of Reason. (See WWR, I, Appendix p. 432).

${ }^{31}$ Schopenhauer, WWR, I, p. 56.

${ }^{52}$ Christopher Janaway, Self and World in Schopenhauer's Philosophy, (Oxford: Clarendon Press, 1989), p. 163. 
way is ipso facto making judgements, and doing so according to the concept of cause (or cause and effect) ${ }^{33}$

Here Janaway would seem to be making a case for the implicit use of concepts by the Understanding rather than their explicit use by the faculty of Reason. ${ }^{54}$ Nietzsche was arguably aware of this alternative and understood perception to involve the implicit rather than explicit use of concepts. ${ }^{55}$ That Nietzsche does not consider intuition to be entirely extra-conceptual can be seen from his questioning, in "On Schopenhauer", of the plausibility of Schopenhauer's view of intuition. Nietzsche suggests that any intuition of the thing-in-itself as Will involves, contrary to Schopenhauer's own suggestion, borrowing the predicates of our cognition and transferring them to a sphere that lies outside the parameters of our cognition. As we witnessed earlier, Nietzsche states that Schopenhauer is forced to deck out a "totally obscure, inconceivable $X$ " in "brightly coloured clothes, with predicates drawn from a world alien to it, the world of appearance." ${ }^{\text {56 }}$ In so doing, Nietzsche rejects the possibility of an unmediated extra-conceptual and extra-cognitive intuition of the thing-in-itself. Therefore, Nietzsche claims that Schopenhauer places the Will in place of Kant's thing-in-itself only by means of a "poetic intuition". ${ }^{57}$ A poetic intuition constitutes,

\footnotetext{
${ }^{53}$ Ibid., p. 164.

${ }^{54}$ Schopenhauer would seem to concede this argument when he distinguishes his own philosophy from that of Kant in the following way:

Philosophy, therefore, is for him a science of concepts, but for me a science in concepts [---] (WWR, I, p. 453).

ss That Nietzsche thinks that this is implicit in Schopenhauer's writings can be seen from Nietzsche's praise of Schopenhauer's "immortal doctrine[s] of the intellectuality of intuition" in The Gay Science, translated by Walter Kaufmann, (New York: Vintage Books, 1974), 99. [Hereafter cited as GS]. However, Nietzsche also attributes to Schopenhauer the view that extra-conceptual intuition of the thing-in-itself is possible. The attribution of two contradictory views to Schopenhauer is arguably not inconsistent on Nietzsche's part because he claims that Schopenhauer contradicted himself "on almost every point". (GS, 99). However, I am concerned to address Nietzsche's response to the latter extraconceptual interpretation of Schopenhauer's project. For Schopenhauer's view that perception is intellectual see WWR, I, p. 443.

${ }^{56}$ Nietzsche, OS, paragraph 3 p. 262.

${ }^{57}$ Ibid., paragraph 2 p. 260.
} 
for Nietzsche, unmediated access to the nature of things. Nietzsche's claim that the Will can only be expressed in terms of predicates borrowed from the realm of appearance suggests that he thinks that Schopenhauer's conception of intuition is cognitively impotent and so cannot facilitate immediate knowledge of the Will/thingin-itself. This further suggests that intuition is, for Nietzsche, imbued with the forms of our cognition. Thus the Dionysiac is imbued with Apolline form.

If we accept this as a plausible reading, then, it seems that we can resolve the tension outlined above. We saw that Nietzsche simultaneously holds that the Apolline and the Dionysiac are interdependent, and that music, as the expression of the Dionysiac, is extra-conceptual and so does not require the Apolline forms of our knowing. The latter claim suggests that Nietzsche posits the Apolline and the Dionysiac as irreconcilable opposites. However, on closer examination it would seem that we now have grounds to suggest that such a reading is mistaken. It may be argued that when Nietzsche claims that music is extra-conceptual what he has in mind here when employing the term "conceptual" are pure concepts that are unconstrained by reality. Considering this, it now seems that we can best explain Nietzsche's claim that music is extra-conceptual as a rhetorical introduction of his criticism of both Euripides and Socrates. For Socrates, like Schopenhauer, separates Reason and instinct. However, Socrates, in Nietzsche's view, represents a position opposite to that of Schopenhauer. Whereas Schopenhauer had placed the emphasis on extraconceptual intuition with regard to knowledge of the nature of the thing-in-itself, Socrates places the emphasis on conceptual knowledge that is unmediated by intuitions. Nietzsche is critical of what he considers to be Socrates' view that Reason 
is an extra-empirical faculty that descends upon empirical chaos and gives it rational order. The problem with this conception of Reason, according to Nietzsche, is that it conceives the concepts of Reason as unconstrained by intuitions. In so doing, Nietzsche maintains that Socrates construes the ordering principle of empirical reality as extra-empirical in character. In chapter four we will see that Nietzsche attempts to remedy this problem by placing the ordering principle within nature itself. This principle he will call the will to power. However, Nietzsche can be seen to initiate this project from as early as The Birth of Tragedy when he claims that both the Apolline and the Dionysiac forces emerge from within nature itself. It is perhaps in this sense that we can explain Nietzsche's view in The Birth of Tragedy that nature is a world artist. $^{58}$

By evoking the idea of the world artist Nietzsche aims to emphasize his reciprocity thesis regarding the relationship between intuitions and concepts. In so doing, he is keen to point out, what he considers to be the limits of the scientific thinking put forward by Socratic rationalism. The scientific man is, for Nietzsche, the theoretical man who suffers from a "profound delusion which first appeared in the person of Socrates, namely the imperturbable belief that thought, as it follows the thread of causality, reaches down into the deepest abysses of being, and that it is capable, not simply of understanding existence, but even of correcting it." ${ }^{59}$ In addition to the claim that Reason is an extrinsic regulator of empirical experience, the theoretical man, as interpreted by Nietzsche, believes that Reason can penetrate the

\footnotetext{
${ }^{58}$ Nietzsche, BT, p. 19 paragraph 2 . It would seem from this that Nietzsche thinks that to see the world as intrinsically ordered from within entails ascribing some form of intellect to the world. Nietzsche does something similar in his mature metaphysical doctrine of the will to power. There, Nietzsche
} 
nature of reality as it is in itself and thus formulate one true unrevisable description of this reality. Nietzsche states of the theoretical man that "his desire finds its highest goal in a process of unveiling which he achieves by his own efforts and which is always successful. ${ }^{960}$ Here Nietzsche attributes to the theoretical man the view that reality as it is in itself is accessible via pure concepts. In contrast to such "optimism" Nietzsche claims that the nature of reality is impenetrable. By this I take Nietzsche to mean that reality is not accessible by pure concepts alone. Moreover, it also entails, for him, a rejection of the idea that Reason can furnish us with one final and unrevisable theory. Our inquiry into the nature of reality is, in Nietzsche's view:

[--] like those people who want to dig a hole right through the earth, each of whom recognizes that even if he exerts all his might his whole life through, he will only be able to dig down through a very tiny piece of the vast depths, and that this piece is being filled in again, before his very eyes, by the work of his neighbour, so that a third person would apparently be well advised to go off and choose a new place for his own attempts at boring a hole. If one person now proves convincingly that the goal in the Antipodes cannot be reached, who will want to carry on labouring down in the old depths, unless in the meantime he has become content with finding precious stones or discovering the laws of nature? ${ }^{61}$

In contrast to his interpretation of Socratic rationalism, Nietzsche espouses the virtues of ongoing and regulative research. He speaks of "[--] why Lessing, the most honest of theoretical men, dared to state openly that searching [my italics] for the truth meant more to him than truth itself [---]". ${ }^{62}$ Nietzsche maintains that the theoretical man will be confronted by the impenetrability of Being and thus that science/theory will be eventually confronted with its own limits. He suggests that when logic and scientific theory reach their limits they give way to art. He states that the

ascribes an "inner will" to things. It will be seen later in this chapter that he considers that the intellect and the will are one rather than distinct from each other.
${ }^{59}$ Ibid., p. 73 paragraph 15.
${ }^{60}$ Ibid., pp. 72-3 paragraph 15.
${ }^{61}$ Ibid., p. 73 paragraph 15.
${ }^{62}$ Ibid. 
metaphysical pretensions of the theoretical man "leads it to its limits time after time, at which point it must transform itself into art, which is actually, given this mechanism, what it has been aiming at all along. " 63

Art, according to Nietzsche, is the product not of one principle or faculty. Rather in The Birth of Tragedy it is the product of a synthesis of the Apolline and the Dionysiac. Art differs from the logicism of the scientific theoretical man in that it attempts to bring together the rational and the instinctive. It may arguably be claimed that by synthesizing the Apolline and the Dionysiac Nietzsche attempts to reconcile self and world without escaping to either an extra-conceptual (Schopenhauer) or extra-sensuous (Socrates) position. In this way Nietzsche makes the internal realist point that we cannot step outside our own particular human mode of knowing but that it is still possible from within these limitations to claim knowledge of the nature of reality. In "On Schopenhauer", 3 he states of Schopenhauer that "[---] it is completely correct of him to say, in WWR I: 'that we can never get at the essence of things from outside". Nietzsche thus states that the Dionysiac, which is a direct copy of the nature of things, is always known through Apolline forms. He states:

I have used the phenomenon of the lyric poet to show how, in him, music struggles to inform us about its nature in Apolline images. ${ }^{64}$

Furthermore, he states:

I conclude that music is able to give birth to myth, i.e. to the most significant example, and in particular to tragic myth, myth which speaks of Dionysiac knowledge in symbols. ${ }^{65}$

Thus Nietzsche suggests that Apollo eventually speaks the language of Dionysus. ${ }^{66}$ Here I take Nietzsche to mean that the synthesis of the Apolline and the Dionysiac,

\footnotetext{
${ }^{63}$ Ibid.

${ }^{64}$ Ibid., p. 80 paragraph 16.

${ }^{65}$ Ibid., p. 79 paragraph 16.
} 
which he calls tragic knowledge, ${ }^{67}$ involves some relationship to truth. In other words, the synthesis of the two impulses does not result in mere appearance but rather it goes some way to accessing truth (Dionysiac) without overstepping our specific cognitive limitations (Apolline). Nietzsche demarcates tragic mediated knowledge from both unmediated Socratic rational knowledge and unmediated Schopenhauerian sensuous knowledge, by terming his own particular form of truth probability. This is suggested in the unpublished essay 'The Dionysian World View'. Here Nietzsche identifies the Apolline and the Dionysiac with Beauty and Truth respectively. ${ }^{68}$ However, when explaining the synthesis of the two in tragic knowledge their status is altered. Their new status is that of a midpoint between pure truth and pure appearance. In tragic art, Nietzsche says:

Apollo and Dionysos have become united. Just as the Dionysiac element penetrated Apolline life, just as semblance established itself as a limit here too, so, equally, Dionysiac-tragic art is no longer 'truth' [---] Truth is now symbolized, it makes use of semblance, [--- $]^{69}$

Furthermore Nietzsche states that

Semblance is certainly not enjoyed as semblance any longer, but rather as a symbol, as a sign of truth. ${ }^{70}$

${ }^{66}$ Nietzsche states:

Thus the difficult relationship of the Apolline and the Dionysiac in tragedy truly could be symbolized by a bond of brotherhood between the two deities: Dionysos speaks the language of Apollo, but finally it is Apollo who speaks that of Dionysos. At which point the supreme goal of tragedy, and indeed of all art, is attained. (Ibid., p. 104 paragraph 21).

${ }^{67}$ Nietzsche states that when science becomes aware of its limitations, scientific knowledge gives way to tragic knowledge. This happens when the scientific man

"[---] sees how logic curls up around itself at these limits and finally bites its own tail, then a new form of knowledge breaks through, tragic knowledge which, simply to be endured needs art for protection and medicine." (Ibid., p. 75 paragraph 15).

${ }^{68}$ Friedrich Nietzsche, "The Dionysian World View" translated by Ronald Speirs, in The Birth of Tragedy and Other Writings, p. 126. Hereafter cited as DWW.

${ }^{69}$ Nietzsche, DWW, p. 133.

${ }^{70}$ Ibid. 
This happens, according to Nietzsche, in both comedy and sublime art. ${ }^{71}$ Both art forms constitute, in Nietzsche's view, a "middle world" between Apolline beauty and Dionysiac truth. In this way Nietzsche maintains that the Dionysiac man

"goes beyond beauty and yet does not seek truth. He remains hovering half-way between these things. He does not strive after beautiful semblance, not after truth, but after probability (Symbol, sign of truth)."72

So far I have examined the reciprocal relationship between the Dionysiac and the Apolline. In so doing, I have suggested that Nietzsche moves away from the view that the attainability of truth requires unmediated access to the nature of reality. Furthermore, I have argued that Nietzsche's rejection of metaphysical oppositions entails a more complex view of truth that can be articulated only from within the Apolline forms of our knowing. Nietzsche's rejection of unmediated absolute truth in favour of truth as probability further suggests that, for him, truth is, contrary to Socratic rationalism, a revisable affair. Thus there is a sense in which it can be said that The Birth of Tragedy pre-empts Nietzsche's later claim in Beyond Good and Evil that there are no absolute standards of truth and falsity but rather only lighter and darker shades of appearance:

Really, why should we be forced to assume that there is an essential difference between 'true' and 'false' in the first place? Isn't it enough to assume that there are degrees of apparency and, so to speak, lighter and darker shadows and hues of appearance - different valeurs, to use the language of painters? ${ }^{73}$

However, the manner in which Nietzsche's mediated conception of human knowing is to be classed as knowledge and thus subject to a realist constraint has yet to be elucidated in detail. In the remaining two sections of this chapter I will proceed with such an elucidation. This will involve an examination of the role of both Gesture and

\footnotetext{
${ }^{71}$ Ibid., p. 130

72 Ibid.
} 
instinctive intellect in the penultimate section, and an analysis of the relationship between art and science in the final section. Both these analyses will bring the nature of Nietzsche's emerging internal realism into closer view.

\subsection{Gesture and Instinctive Intellect}

In examining the role of Gesture in Nietzsche's early writings I am concerned to rebuke a line of thought in the Nietzsche literature that argues that his early writings put forward an extra-conceptual, and therefore, unmediated mode of knowledge. It is important that I address this view as it threatens my claim that in the early writings Nietzsche was struggling to extricate himself from both the Kantian distinction between appearances and reality, and Schopenhauerian metaphysics. Moreover, my examination of Gesture, coupled with an analysis of what Nietzsche terms the instinctive intellect, will draw our attention to Nietzsche's further notion of affective reasoning, which, in turn, will bring his emerging internal realism into focus. For, as we shall see, this emerging internal realism entails the view that our specifically human truths are both adequate to and constrained by reality. I will proceed, then, by examining the role of Gesture in Nietzsche's early writings.

Maudemarie Clark is one commentator who interprets Nietzsche's appeal to Gesture as an appeal to an unmediated and direct form of knowledge. Clark maintains contrary to my interpretation so far, that Nietzsche espouses artistic unmediated knowledge of the thing-in-itself in The Birth of Tragedy and that such knowledge is incommunicable and only related through the medium of Gesture. She states:

\footnotetext{
${ }^{73}$ Nietzsche, BGE, 34.
} 
[---] Nietzsche claims that tragedy begins with a kind of non-conceptual, non-linguistic experience, in which the artist becomes one with the realm beyond individuality and description, the thing in itself. Although this experience of the thing in itself is incommunicable, it gives rise to a vision which the artist describes in language and images that are able to induce in spectators the same pre-linguistic and incommunicable experience of the thing in itself. $^{74}$

Nietzsche's appeal to Gesture in his early writings, as can be seen from the Clark citation above, has been taken to be, incorrectly in my view, a pre-linguistic and preconceptual affective experience. It is often argued that Nietzsche's appeal to the instinctual bodily movement of dance or feelings supports such a reading. ${ }^{75}$ However, Clark's view relies on an interpretation of Nietzsche's understanding of Gesture as an extra-conceptual intuition that is to be distinguished from concepts as extra-sensual rational modes of thought. This reading is encouraged by "On Truth and Lies" where Nietzsche draws a distinction between the intuitive man and the conceptual man. He claims that the intuitive man

[---] will now be guided by intuitions rather than by concepts. There is no regular path which leads from these intuitions into the land of ghostly schemata, the land of abstractions. There exists no word for these intuitions; when man sees them he grows dumb, or else he speaks only in forbidden metaphors and in unheard-of combinations of concepts. He does this so that by shattering and mocking the old conceptual barriers he may at least correspond creatively to the impression of the powerful present intuition. ${ }^{76}$

However, as remarked in our earlier examination of "On Truth and Lies", it is not clear from this passage that intuition is extra-conceptual. Rather, it may be read as claiming that intuition entails a creative rather than a constitutive use of concepts to the extent that our concepts regulate our inquiry but do not constitute reality. Moreover, Clark's interpretation of The Birth of Tragedy as espousing the view that unmediated direct intuitional knowledge of the thing-in-itself is possible, identifies

\footnotetext{
${ }^{74}$ Clark, "On Knowledge, Truth and Value", p. 45.

${ }^{75}$ Nietzsche, DWW, p. 135.

${ }^{76}$ Nietzsche, TL, p. 90 paragraph 2.
} 
intuitional knowledge with pure Dionysiac knowledge. Therefore, only if Nietzsche puts forward the possibility of pure Dionysiac knowledge, unmediated by the Apolline forms of our knowing, can one reasonably claim that he is adopting the view that unmediated intuitive knowledge is possible. However, in the previous section I argued that Nietzsche disallows the possibility of pure Dionysiac extra-conceptual knowledge. Furthermore, if we look more closely at some of the passages where Nietzsche discusses the issue of intuitions and concepts it seems that the difference between them is really, in his view, only a difference in degree rather than in kind. In “Dionysian World View", for example, Nietzsche states:

Symbols can and must be many things; but they grow instinctively and with great and wise conformity to a law. A symbol that is remembered is a concept $[\cdots--]^{77}$

Gesture (Intuition) is, for Nietzsche, a symbol. In "Dionysian World View" he speaks of the "symbolism of gesture". ${ }^{78}$ Thus in the above citation he suggests that a concept is a remembered intuition. As such the concept transcends, in Nietzsche's view, the particular momentary character of the intuition and preserves it, albeit in a less lively manner, across time. This suggests that the form that belongs to the concept is already present in sensuous time-bound fashion in the intuition itself. The concept can be explained, in this sense, as an abstracted intuition, an intuition grown cold and preserved in the memory over time. ${ }^{79}$ Concepts thus play a practical role in regulating

\footnotetext{
77 Nietzsche, DWW, p. 137.

${ }^{78}$ Ibid., p. 136. See also p. 135.

79 Some may wonder whether Nietzsche says anything different about the nature of concepts than Hume. For Hume, the concept is distinguished from the sensation merely in terms of its diminished force or vivacity. However, Nietzsche's treatment of the role of concepts differs from that of Hume because Nietzsche attributes to concepts a stronger and more substantial role. Hume puts forward an atomistic account of experience where the concept has legitimate application to an isolated moment of time. In so doing, Hume is forced to claim that our inferences to future happenings are not rationally warranted. Nietzsche, however, in claiming that the intuition is itself imbued with conceptual form allows that the concept is intimately related to the nature of reality and thus that they can be employed to make valid regulative claims or inferences about the nature of reality. By this I mean that the
} 
and simplifying experience. That Nietzsche denies that intuition is extra-conceptual can be further discerned from his identification of intuitions and concepts with unconscious and conscious thought respectively. ${ }^{80}$ In Beyond Good and Evil, 3 he claims that there is very little difference between unconscious and conscious thought to the extent that the one is really a form of the other. He states:

Having long kept a strict eye on the philosophers, and having looked between their lines, I say to myself: the largest part of conscious thinking has to be considered an instinctual activity, even in the case of philosophical thinking; we need a new understanding here, [---] 'consciousness' is scarcely opposite to the instincts in any decisive sense - most of a philosopher's conscious thinking is secretly guided and channeled into particular tracks by his instincts. ${ }^{81}$

Feeling or Gesture, as construed by Nietzsche, may then be seen, not as a preconceptual affecting, but rather as affections already imbued with conceptual form.

This is further suggested by Nietzsche's claim that gestural language/symbols "grow instinctively and with great and wise conformity to a law". 82 Moreover, it would seem that the reason for Nietzsche's emphasis on Gesture rather than pure conceptual thought is founded on his view that all knowledge claims must be made from within our concrete embodied rootedness in the world. It is in this light that we can explain Nietzsche's appeal to dance and his view that "the intellect itself and the will are one" ${ }^{83}$ Gesture, then, in Nietzsche's early writings, may be seen as a precursor of his account of affective reasoning developed in the later writings. David Owen articulates this conception of reasoning in the following:

concept is, for Nietzsche, a second order tool that is not literally abstracted from the momentary sensation. Rather, the claim that concepts have their origin in intuitions is itself a regulative claim introduced to "explain" the intimate relationship between reality itself and those select concepts that are judged to capture the nature of reality.

${ }^{80}$ Nietzsche, DWW, p. 137.

81 Nietzsche, BGE, 3.

${ }^{82}$ Nietzsche, DWW, p. 137.

${ }^{83}$ Friedrich Nietzsche, "Anschauung Notes" in Claudia Crawford, Nietzsche's Theory of Language, (New York: Walter de Gruyter, 1988), p. 271; KSA 7:128 [123] Hereafter cited as AN. 
Our consciousness is neither disembedded nor disembodied; knowing, like seeing, is an activity which attends the embedded and embodied character of human subjectivity. Consequently, we can conclude that for Nietzsche our cognitive constitution is not separable from our affective constitution, our cognitive interests are not independent of our affective interests: logos is entwined with eros. ${ }^{84}$

This notion of affective reasoning is also developed in Nietzsche's idea of instinctive intellect, which, we shall now see, provides his early thought with the necessary resources to overcome the influence of both Kant and Schopenhauer. In particular, "instinctive intellect" is designed to overcome what Nietzsche sees as Kant and Schopenhauer's extra-empirical subject of knowing. ${ }^{85}$ Nietzsche's conception of instinctive intellect is articulated in the early unpublished notes and may be construed as an attempt to reconcile self and world by showing that our human knowledge is

${ }^{84}$ David Owen, Nietzsche, Politics and Modernity, (London: Sage Publications, 1995), p. 33.

${ }^{85}$ However, Schopenhauer's conception of the subject is complicated and not altogether clear. He puts forward a view of the subject that is split in two ways. Firstly, there is the pure subject of knowledge, which he identifies with the Kantian transcendental subject. For both Schopenhauer and Kant, the transcendental subject is a non-temporal, non-spatial and non-causal subject. The knowing subject, therefore, cannot be an object of knowledge in either Schopenhauer's or Kant's system. Schopenhauer describes what is meant by the "transcendental subject" in the following:

If we summarize Kant's utterances, we shall find that what he understands by the synthetic unity of apperception is, so to speak, the extensionless centre of the sphere of all our representations, whose radii converge on it. It is what I call the subject of knowing, the correlate of all representations [---]. (Schopenhauer WWR, I, pp. 451-2).

Secondly, Schopenhauer identifies an embodied willing subject. It is when we consider the relation between the two conceptions of the subject that we encounter difficulties. Schopenhauer maintains that the "P" arises from the comprehension of an identity between the knowing subject and the willing subject. He claims that the knowing subject recognizes the will as the basis of its own appearance. However, this is incompatible with Schopenhauer's identification of the knowing subject with the transcendental subject. The knowing subject, cannot according to this view, recognize itself as an appearance. Rather, the knowing subject is a "focal point" of representations and thus, like Kant's transcendental subject, cannot itself be an appearance. An identity of the knowing subject and the willing subject is also precluded by Schopenhauer's claim that the intellect is under the control of the will. (WWR, II, p. 140ff). In so doing, Schopenhauer posits the will as primary to the intellect. He argues that the will censors the intellect and thus that the will can be certain of things whilst the intellect remains in ignorance. It is perhaps as a result of these difficulties that Nietzsche claims that Schopenhauer remained confused regarding the origin of the intellect. (OS, 4). Furthermore, in Human, All Too Human Nietzsche describes Schopenhauer's doctrine of the primacy of the will over the intellect as an "error". ["Assorted Opinions and Maxims" in Human, All Too Human, Volume II, Part One, translated by R. J. Hollingdale, (Cambridge: Cambridge University Press, 1986), paragraph 5]. The reason for this may be due to Nietzsche's own view, articulated in BGE, 19 that the intellect and the will are not distinct entities. Nietzsche states:

[---] just as we must recognize feeling, and indeed many kinds of feeling, as an ingredient of the will, so must we likewise recognize thinking: in every act of will there is a commanding 
subject to a realist constraint. Thus we will see that Nietzsche's notion of instinctive intellect represents an attempt to formulate a mode of knowing that is rooted within and has access to the nature of the world.

In 'On the Origins of Language' (1869-70) Nietzsche outlines his proposal of an unconscious and instinctive intellect. He states that "Instinct is one with the innermost kernel of a being. This is the real problem of philosophy, the unending expediency of organisms and the unconsciousness in their coming to be". 86 Moreover, he identifies the unconscious and instinctive intellect with perceptual thinking. In 'The Philosopher' he states:

Unconscious inferences set me to thinking: it is no doubt a process of passing from image to image. The image which is last attained then operates as a stimulus and motive. Unconscious thinking must take place apart from concepts: it must therefore occur in perceptions (Anschauungen). ${ }^{87}$

Here Nietzsche would seem to suggest that unconscious perception is extraconceptual. However, as suggested in my earlier examination of the relation between concepts and intuitions, it transpires that intuition is merely non-abstract rather than extra-conceptual. Nietzsche's understanding of perceptual thinking is complex for it seems to contain within itself an intellectual component. This is suggested in Nietzsche's praise for the "intellectuality of intuition. ${ }^{, 88}$ Furthermore, in the early

thought, and we must not deceive ourselves that this thought can be separated off from 'willing', as if we would then have any will left over!

${ }^{86}$ Nietzsche, AN, p. 223.

87 Friedrich Nietzsche, "The Philosopher" in Philosophy and Truth: Selections from Nietzsche's Notebooks of the Early 1870 's, paragraph 116.

${ }^{88}$ Nietzsche, GS, 99. As remarked earlier, Nietzsche attributes this view to Schopenhauer. It would seem to be Nietzsche's view that Schopenhauer ultimately remained confused as to the true character of intuition. I am not here concerned to address this issue. It is sufficient to note in the context of our examination that Nietzsche praises the intellectuality of intuition and rejects the idea of extraconceptual intuition. Which of these views is more correctly attributed to Schopenhauer is beyond the scope of the present analysis. 
notes Nietzsche describes Anschauung as Anordnung. ${ }^{89}$ Here he suggests that our

perceptual experience is always an orderly one. In so doing, he puts forward the view

that, contrary to initial appearances, there is no great distinction to be made between

perception and intellect. Crawford suggests this in the following:

In reading Hartmann, Nietzsche comes to vizualize a completely unconscious process of thinking which has a certain logic or inferential quality of its own and which functions as a basis for conscious discursive activity. It is a process which consists of an "interblending of the discursive and intuitive methods" of the unconscious and conscious aspects of mental activity. A process which arises out of the reality of instinct and the limits of human organization. $^{90}$

This view of intuition can be seen as one of Nietzsche's attempts to naturalize the intellect and so reject the constitutive conception of the knowing intellect that is said to order the world from an extra-empirical vantage point. In the collection of unpublished notes entitled 'The Philosopher' Nietzsche puts forward the view that the human intellect is part of nature in opposition to the idealist view that he attributes to both Schopenhauer and Kant that the intellect constitutes the empirical world of individuated objects. ${ }^{91}$ According to Nietzsche such idealism goes hand in hand with

${ }^{89}$ Crawford, Nietzsche's Theory of Language, p. 161.

${ }^{90}$ Ibid., p. 49.

91 That Nietzsche adopts a non-constitutive conception of the knowing intellect can be further discerned from some of his early notes, which Claudia Crawford has grouped together under the title "Anschauung Notes" (1870-1871). In some of these notes, Nietzsche posits a metaphysical Ur-Eine, which represents itself as an appearance. He maintains that space, time, and causality belong to these appearances. However, unlike Kant and Schopenhauer, Nietzsche maintains that these forms are not transcendental forms imposed by the subject but rather that they emanate from the self-objectifying will itself. He states:

I hesitate to trace space, time and causality from the pitiful human consciousness; they belong to the will. They are the condition for all symbolics of appearance: man himself is such a symbol, as is the state, the earth. This symbolism is not unconditionally there for man alone. (Nietzsche, AN, p. 271, KSA 7: 114-115, 5, [81]).

Here Nietzsche suggests that, contrary to both Kant and Schopenhauer, the predicates that we apply to the realm of experience actually belong to the thing-in-itself. Moreover, Nietzsche claims that the thing-in-itself objectifies itself in the human world. Thus the predicates that belong to the thing-initself, according to him, also belong to the human world. Thus, there is, in Nietzsche's view, no epistemic gap between our human knowledge and the nature of the world. This is because, he suggests, we do not constitute the world. Rather the world makes itself known to us. This claim, however, is extremely problematic for it is in conflict with what we have seen is the perspectival and regulative direction of Nietzsche's thought in other passages from the early writings. This latter aspect of his 
scepticism. ${ }^{92}$ Both Schopenhauer and Kant's particular brand of idealism entails, in

Nietzsche's view, a distinction between how things are constituted by the human mind and how they are constituted in themselves. Nietzsche articulates the type of idealism that he attributes to both Schopenhauer and Kant in the following passage:

Even the Kantian theory of knowledge was immediately employed by man for his own selfglorification: the world has its reality only in man. It is tossed back and forth like a ball in the heads of men. In truth however this theory means only this: Though one might think that there exists both a work of art and a stupid man to contemplate it, of course the work exists as a cerebral phenomenon for this stupid man only to the extent that he is himself an artist as well and contributes the forms [to the work]. He could boldly assert, "the work of art has no reality outside of my brain." 93

It is important to note here that Nietzsche does not clearly distinguish between transcendental and empirical idealism. It is fair to say that Nietzsche's understanding of Kant is mediated through Schopenhauer. Schopenhauer interprets Kant's transcendental idealism as a form of subjective idealism and even suggests that Kant should have been a Berkeleian. ${ }^{94}$ Thus the view that Nietzsche attributes to Kant here is the view that pure concepts constitute an otherwise unformed chaos of sensations into an individuated realm of empirical objects. Nietzsche's desire to overcome this idealism entails a rejection of the conscious intellect as the key to knowledge. For to privilege the conscious intellect, according to Nietzsche, entails the idealist view that abstract concepts or "empty husks" are imposed on an unformed realm of sensations.

thought entails, as we have seen in both chapters one and two, the Kantian thesis that we make the object known rather than the dogmatic view that the object makes itself known to us. On a more positive note, however, although we cannot explain the above claims in AN as anything other than an inconsistency on Nietzsche's part, they do make clear that he is interested in ascertaining that our human knowledge is adequate to reality. This supports the claim made in this thesis that Nietzsche is interested in making objective metaphysical claims about the nature of reality. This theme will be taken up once again in chapter four where we will see that Nietzsche demonstrates that it is possible to put forward objective metaphysical claims about the nature of reality without engaging in dogmatic metaphysics.

92 In "Schopenhauer as Educator", 3, Nietzsche describes Kant as a sceptic.

${ }^{93}$ Nietzsche, "The Philosopher", paragraph 106 . There is a similarity between Nietzsche's description of transcendental idealism here and his description of empirical idealism in BGE, 15. 
Despite Nietzsche's rejection of the conscious intellect, it is clear from the notes that he has not completely extricated himself from the influences of his masters and that at times he himself lapses into the idealism that he associates with Schopenhauer and Kant. For example, he adopts the sceptical position that he attributes to Kant in the following passage:

Knowing is nothing but working with the favorite metaphors, an imitation which is no longer felt to be an imitation. Naturally therefore, it cannot penetrate the realm of truth. ${ }^{95}$

However, in the notes of the same period Nietzsche also formulates a decidedly antisceptical and therefore, in Nietzsche's view, anti-Kantian thesis. He states:

The forms of the intellect have gradually arisen out of the matter. It is plausible in itself that these forms are strictly adequate to the truth. For where is an apparatus which could invent something new supposed to have come from? ${ }^{96}$

By attempting to overcome both Kant and Schopenhauer, Nietzsche strives to overcome the view that the realm of our empirical experience is extrinsically constituted rather than having an intrinsic order. ${ }^{97}$ The view that the empirical world is constituted extrinsically suggests that the knowing subject is set apart from the world of our experience. Nietzsche's reference to an unconscious intellect, in contrast, sets up an alternative picture wherein the subject is an evolving part of a larger evolving whole. He writes:

Now man has evolved slowly, and knowledge is still evolving: his picture of the world thus becomes ever more true and complete. Naturally it is only a clearer and clearer mirroring. But the mirror itself is nothing entirely foreign and apart from the nature of things. On the contrary it too slowly arose as [part of] the nature of things. We observe an effort to make the mirror more and more adequate. The natural process is carried on by science. Thus the things mirror themselves ever more clearly, gradually liberating themselves from what is all too anthropomorphic. ${ }^{98}$

\footnotetext{
${ }^{94}$ Schopenhauer, WWR, I, pp. 434-5.

${ }^{95}$ Nietzsche, "The Philosopher", paragraph 149.

${ }^{96}$ Ibid., paragraph 106.

${ }^{97}$ In DWW Nietzsche speaks of the "unreasonable but planned nature of events", p. 131.

${ }^{98}$ Nietzsche, "The Philosopher", paragraph 102.
} 
Before I bring this section to its final conclusion I must briefly address Nietzsche's claim in 'The Philosopher', 102 cited above that his revised conception of the knowing subject as immersed in the world facilitates an overcoming of scepticism. Nietzsche argues that it is possible to gain adequate knowledge from within this revised framework. Moreover, he suggests that adequate knowledge entails an overcoming of anthropomorphism. We must tread carefully here in order to avoid the mistake of attributing to Nietzsche the claim that ultimately knowledge involves escaping the human point of view in favour of some extra-perspectival God's Eye View. We can avoid this mistake, however, by recognizing that when Nietzsche suggests in the above citation that overcoming idealism and scepticism entails overcoming anthropomorphism, he means that it requires overcoming idealist anthropomorphism, or what may be called in this context, first order anthropomorphism. This first order anthropomorphism involves, according to Nietzsche, the view that we constitute the world. Nietzsche replaces this view with a second order anthropomorphism that stipulates that we explain phenomena in anthropomorphic terms. This latter position does not entail that empirical experience is reducible to the activity of our intellect. Thus Nietzsche states:

The progress of philosophy: It was first thought that men were the authors of all things. Gradually one explained [my italics] things to himself by analogy with particular human qualities. ${ }^{99}$

From this we can see that it is Nietzsche's view that our anthropomorphic manner of knowing is conducive to truth. Moreover, he suggests at this early stage in his philosophical development that our knowledge is regulative rather than constitutive in character. The regulative character of our knowledge is further elucidated in 
Nietzsche's attempt to reconcile factualism with normativity. It is here that his early writings meet his mature thought and set him on the path to completing his internal realism and consequently overcoming the opposition of self and world. It is to this issue that I now turn.

\subsection{Factualism and Normativity: The Reciprocity of Science and Art}

So far I have examined Nietzsche's early writings in an attempt to ascertain his emerging solution to the problem of the opposition of self and world. We have seen that the logic of Nietzsche's thought militates against the possibility of unmediated knowledge. He maintains that all knowledge is mediated by our specifically anthropomorphic manner of knowing. Furthermore, he puts forward the Apolline and the Dionysiac as interdependent and thus suggests that truth is not divorced from human knowledge. In this section I will briefly outline the emergence of Nietzsche's regulative conception of knowledge that we witnessed in both chapters one and two. We will see that this regulative epistemology facilitates the making of objective metaphysical claims about the nature of reality. Thus in this final section I will endeavour to draw together some of the strands introduced in the preceding sections. In so doing, we will see the manner in which Nietzsche situates the human knower firmly within access to the nature of things. I will embark upon this task by turning to Nietzsche's attempt to reconcile normativity with factualism. As this chapter is designed to act as a prelude to Nietzsche's mature overcoming of the opposition of self and world, and my discussion of his will to power metaphysics, I will now begin

\footnotetext{
${ }^{99}$ Ibid., paragraph 103
} 
to examine his early view in the light of his mature solution. This section will, then, contain reference to both his early and late writings.

In 'On the Uses and Disadvantages of History for Life' (1873) Nietzsche is critical of reverence for extra-perspectival facts and disinterested knowledge. Factualism, according to Nietzsche, entails two different, though compatible views. Firstly, it entails the view that the world will reach an endpoint and that truth is properly conceived as identical to this final state of affairs. Secondly, factualism is said to be identical with the God's Eye View of knowledge. Nietzsche identifies such factualism with Hegel and the view that the world has reached a rational optimum. He writes:

History understood in this Hegelian fashion has been mockingly called God's vicissitudes on earth, though the god referred to has been created only by the history. This god, however, became transparent and comprehensible to himself within the Hegelian craniums and has already ascended all the dialectically possible steps of his evolution up to this self-revelation: so that for Hegel the climax and terminus of the world-process coincided with his own existence in Berlin. Indeed, he ought to have said that everything that came after him was properly to be considered merely as a musical coda to the world-historical rondo, or even more properly, as superfluous. He did not say it: instead he implanted into the generation thoroughly leavened by him that admiration for the 'power of history' which in practice transforms every moment into a naked admiration for success and leads to an idolatry of the factual: which idolatry is now generally described by the very mythological yet quite idiomatic expression 'to accommodate oneself to the facts'. ${ }^{100}$

By positing an end of inquiry and the God's Eye View as the standard of objective truth, factualism, according to Nietzsche, puts forward a disinterested conception of knowledge. The problem with factualism, in Nietzsche's estimation, is that it does not regard the positing of a final and conclusive epistemic goal as a regulative procedure to initiate inquiry, but rather as an end point that is actually achievable and realizable. Thus Nietzsche describes factualism as a position that attempts "To take 
everything objectively, to grow angry at nothing, to love nothing, to understand everything [---]." ${ }^{101}$ This is precisely a view of knowledge that Nietzsche strives to overcome in his early notes on truth and knowledge. In these early notes Nietzsche argues that the idea of disinterested extra-anthropomorphic truth is incoherent. In 'The Philosopher' he argues that "absolute and unconditional knowledge is the desire to know without knowledge", ${ }^{102}$ to which he responds that "All knowledge originates from separation, delimitation, and restriction; there is no absolute knowledge of a whole." ${ }^{103}$ Moreover, Nietzsche maintains that knowledge is properly conceived as an interested mode of inquiry. He states:

All knowing is a process of measuring according to a criterion. Without a criterion, i.e. without any limitation, there is no knowing. It is the same in the realm of intellectual forms. For example, when I ask what might be the value of knowledge as such, I have to adopt some higher position, or at least one that is fixed, so that it can serve as a criterion. ${ }^{104}$

Thus, in opposition to factualism, Nietzsche puts forward a decidedly interested view of knowledge that attempts to reconcile the factual "is" with the normative "thus it shall be". ${ }^{105}$ In "On Truth and Lies" we witnessed a dissonance between the "is" and the "ought to be". There, facts were considered to be incompatible with norms. However, here Nietzsche considers norms to be indispensable to the quest for truth. Here a reconciliation takes place between facts and the appeal to norms. This reconciliation is best articulated in Nietzsche's evocation of something like a "second nature". He claims that the affirmative man that he envisages for the future will

\footnotetext{
${ }^{100}$ Friedrich Nietzsche, "On The Uses and Disadvantages of History for Life" in Untimely Meditations, translated by R. J. Hollingdale, (Cambridge: Cambridge University Press, 1994), p. 105. Hereafter cited as On the Uses.

${ }^{101}$ Ibid., p. 105.

${ }^{102}$ Nietzsche, "The Philosopher", paragraph 114.

103 Ibid., paragraph 109.

${ }^{104}$ Ibid., paragraph 99.

${ }^{105}$ Nietzsche, On the Uses, p. 106.
} 
possess "a more natural nature than its predecessors". 106 Truth, according to

Nietzsche, is a necessary component of this project. Thus he states of the affirmative man that

His honesty, the strength and truthfulness of his character, must at some time or other rebel against a state of things in which he only repeats what he has heard, learns what is already known, imitates what already exists; he will then begin to grasp that culture can be something other than a decoration of life, that is to say at bottom no more than dissimulation and disguise; for all adornment conceals that which is adomed [----] Thus he will learn from his own experience that it was through the higher force of their moral nature that the Greeks achieved victory over all other cultures, and that every increase in truthfulness must also assist to promote true culture: even though this truthfulness may sometimes seriously damage precisely the kind of cultivatedness now held in esteem, even though it may even be able to procure the downfall of an entire merely decorative culture. ${ }^{107}$

Nietzsche's cultured man of the future embodies a form of "second nature" in opposition to pure factualism. This "second nature" involves "the conception of culture as a new and improved physis, without inner and outer, without dissimulation and convention, culture as a unanimity of life, thought, appearance and will". ${ }^{108}$ The new and improved physis, Nietzsche argues, must combine a commitment to truth and normativity. This conception of a "second nature" permeates both Nietzsche's early Twilight of the ldols and mature writings. In speaks of man's "ascent" to nature rather than of his return to a pre-given state of affairs. ${ }^{109}$ In so doing, he attempts to dissolve the distinction between nature and culture in order to press home his view that man is part of nature and not separate from it. If our cultural anthropomorphic life is natural and the natural is the cultural then we are left with no reason to deny man his place in nature or that he has access to truth. For truth, in Nietzsche's view, is internal to our being-in-the world rather than external to it.

\footnotetext{
${ }^{106}$ Ibid., p. 121.

${ }^{107}$ Ibid., p. 123.

${ }^{108}$ Ibid.

${ }^{109}$ Friedrich Nietzsche, Twilight of the Idols, translated by Duncan Large, (Oxford: Oxford University Press, 1998), IX, 48.
} 
From the above we can see that Nietzsche wants to retain a substantial notion of truth and knowledge despite his rejection of the factualist's disinterested conception of epistemological inquiry. Moreover, Nietzsche's desire that human knowledge be both interested and adequate to reality differs markedly from the rationalist's claim that adequate knowledge must be justified through extraperspectival confrontations with reality. Nietzsche's revised conception of knowledge disallows all such confrontations. Nietzsche no longer construes the world as something existing out there, external to us and to which our truth claims must conform. Rather, for Nietzsche, the world is in a perpetual state of evolvement and our embedded interested position in the world participates in this evolution. From this we can see that Nietzsche's aim is to show how mediated knowledge can be equated with truth. He finds the answer to this dilemma, I believe, in the relationship between science and art.

In The Birth of Tragedy, Nietzsche takes as his aim "to look at science through the prism of the artist, but also to look at art through the prism of life." 110 This statement is often interpreted as Nietzsche's early prioritization of art over science. However, this interpretation is complicated somewhat when we consider Nietzsche's statement that "Aesthetics makes sense only as natural science [Naturwissenschaft]: like the Apollinian and Dionysian." "I Furthermore, in Human, All Too Human, 222 Nietzsche maintains that "scientific man is a further development of artistic man", and in Human, All Too Human, 251 he suggests that

\footnotetext{
${ }^{110}$ Nietzsche, BT, p. 5 paragraph 2.

${ }^{111}$ Nietzsche, KSA, 7 16 [6] cited by James I. Porter, The Invention of Dionysus, (Stanford: Stanford University Press, 2000), p. 41.
} 
science is regulated by art. Thus Nietzsche claims that science is a valuable enterprise

if it is regulated by human normative activities. He states:

[---] a higher culture must give to man a double brain, two brain chambers, as it were, one to experience science, and one to experience nonscience. Lying next to one another, without confusion, separable, self-contained: our health demands this. In the one domain lies the source of strength, in the other the regulator. ${ }^{112}$

In this passage Nietzsche puts forward the view that our inquiry must be guided by our "pleasures" if we are to pursue truth. This suggests that, for Nietzsche, knowledge is to be properly conceived as a decidedly interested pursuit rather than the disinterested one of factualism outlined above. In On the Genealogy of Morality Nietzsche argues that science, left untended, is prone to the excessive belief that it alone is the path to the truth because it regards itself as pure disinterested inquiry. He argues that this understanding of the scientific project is a manifestation of the ascetic ideal, which rejects sensuous and interpretive modes of epistemic inquiry in favour of crude factualism whereby "truth" is given pre-packaged. Nietzsche states:

I know all of this from too close a proximity perhaps: that commendable philosophers' abstinence to which such a belief obligates; that stoicism of the intellect that finally forbids itself a "no" just as strictly as a "yes"; that wanting to halt before the factual, the factum brutum; that fatalism of "petits faits" [-- $]$ in which French science now seeks a kind of moral superiority over German science, that renunciation of all interpretation (of doing violence, pressing into orderly form, abridging, omitting, padding, fabricating, falsifying and whatever else belongs to the essence of all interpreting) - broadly speaking, this expresses asceticism of virtue as forcefully as does any negation of sensuality (it is basically only a modus of this negation. ${ }^{113}$

Art is, for Nietzsche, in contrast to what he sees as the above incorrect conception of science, a sensuous and interested engagement with the world. He states:

Human sensory knowledge certainly aims at beauty: it glorifies the world. Why should we snatch at anything else? Why do we seek to transcend our senses? Restless knowledge leads to bleakness and ugliness. Let us be content with the aesthetic view of the world. ${ }^{114}$

\footnotetext{
112 Nietzsche, HAH, 251.

${ }^{113}$ Friedrich Nietzsche, On the Genealogy of Morality, translated by Maudemarie Clark and Alan J. Swensen, (Cambridge: Hackett Publishing Company, 1998), III, 24.

${ }^{114}$ Nietzsche, "The Philosopher", paragraph 113.
} 
An aesthetic view of knowledge differs from a crude factualism, in Nietzsche's view, because it is an imaginative enterprise that envisages numerous possibilities. Art, he claims, makes imaginative speculations regarding the nature of things. Art, then, makes claims about the world that are not immediately conclusive. However, left untended, art can, according to Nietzsche, result in a state of over excitation. Science, he suggests, should play the specific role of cooling down this excitation of artistic possibilities. It can do this by constraining the demands of art through scientific research and the upholding of scientific results. Nietzsche states:

Philosophical thinking can be detected in the midst of all scientific thinking, even in the case of conjectures.

It leaps ahead on nimble legs, while the understanding ponderously wheezes along behind and seeks sturdier legs when the tempting magical image has appeared to it. An infinitely rapid flight through immense spaces! Is philosophical thinking only distinguished by its greater rapidity? No. It is the wingbeat of imagination, i.e. a repeated leaping from possibility to possibility - [---] A process of expansion and amplification now begins. Imagination consists in the quick observation of similarities. Afterwards, reflection measures one concept by another and performs tests. ${ }^{115}$

And again:

There is no distinct philosophy separated from science: there they think in the same manner that we do here. The reason why indemonstrable philosophizing retains some value, and for the most part a higher value than a scientific proposition, lies in the aesthetic value of such philosophizing, in its beauty and sublimity. [--] Therefore, in the culture of a people the knowledge drive is mastered by the imagination. ${ }^{116}$

In the above citations Nietzsche identifies philosophy with the aesthetic activity of imaginative conjecture. Philosophy is thus considered by Nietzsche to be a form of art. The relationship between art as imaginative conjecture and science, according to him, can be articulated as a relationship between inventing and finding. He thus maintains that inventing precedes finding. ${ }^{117} \mathrm{He}$ suggests that artistic conjecture precedes but must be constrained by scientific research. Nietzsche employs the term

\footnotetext{
115 Ibid., paragraph 60.

${ }^{116} \mathrm{Ibid}$., paragraph 61 .

${ }^{117}$ Nietzsche, BGE, 12.
} 
science as Wissenschaft, which entails rigorous methodical scholarship and research.

Here we see Nietzsche argue against, as he sees it, "an unseemly and harmful hierarchical shift between science and philosophy [---]." can understand his description of true philosophy as an "experiment", 119 which incorporates a strict research methodology. This methodology involves, in Nietzsche's view, "[---] the certainty of standards, the conscious use of a unified method [---]. ${ }^{120}$ Philosophy in this sense takes over from art and science as independent activities. Philosophy, as the combination of art and science, constrains aesthetic excesses whilst moderating science's belief in its own activity as disinterested inquiry.

The relationship between art and science is, for Nietzsche, then, that between imaginative conjecture and rigorous methodological constraint in research. The former is, in his view, a pre-requisite for the proper interested and focused stimulation of the latter. He states:

Preludes of science.- Do you really believe that the sciences would ever have originated and grown if the way had not been prepared by magicians, alchemists, astrologers, and witches whose promises and pretensions first had to create a thirst, a hunger, a taste for hidden and forbidden powers? Indeed, infinitely more had to be promised than could ever be fulfilled in order that anything at all might be fulfilled in the realm of knowledge. ${ }^{121}$

That art regulates science in this way is further suggested by Nietzsche's view that all truth claims are initially assumptions defended after the fact. Factualism in philosophy, he contends, attempts to disguise that its claims to truth are not the result

\footnotetext{
118 Ibid., 204.

119 Ibid., 210.

${ }^{120}$ Ibid.

${ }^{121}$ Nietzsche, GS, 300. Nietzsche is here rejecting the idea of extra-perspectival or presuppositionless knowledge. In GM, III, 24 he makes a similar point when he states:

There is, strictly speaking, absolutely no science "without presuppositions," the thought of such a science is unthinkable; paralogical: a philosophy, a "belief" must always be there first
} 
of disinterested inquiry but rather "reasons sought after the fact to defend a preexisting tenet". ${ }^{122}$ Knowledge for Nietzsche is, then, founded upon a delicate interchange between art and science. ${ }^{123} \mathrm{He}$ maintains that art is a necessary prerequisite to getting scientific research off the ground. Equally, however, science is necessary to constrain artistic claims so that artistic conjectures can be transformed into knowledge. That Nietzsche is concerned to stress a scientific constraint to artistic conjecture can be seen from his claim that not all conjectures are worthy of the title knowledge. This is made evident in his claim that Christianity is a misinterpretation of events:

The metaphysical need is not the origin of religions, as Schopenhauer supposed, but merely a late offshoot [----] what first led to the positing of "another world" in primeval times was not some impulse or need but an error in the interpretation of certain natural events, a failure of the intellect. ${ }^{124}$

By emphasizing the notion of a scientific constraint to artistic conjecture Nietzsche suggests that some interpretations (those that are properly constrained) are better than others. He states that "every elevation of man brings with it the overcoming of narrower interpretations". ${ }^{125}$ Thus Nietzsche suggests that there is one world to which our epistemic claims are more or less accurate. In so doing, he attempts to overcome

so that science can derive a direction from it, a meaning, a boundary, a method, a right to existence.

122 Nietzsche, BGE, 5.

${ }^{123}$ It is a point similar to this that I take Nietzsche to be making in his proposal of an artistic Socrates in BT, p. 71 paragraph 14. An artistic Socrates entails, according to this reading, a reciprocal relationship between art and science. Nietzsche states:

Although it is certain that the first effect which the Socratic drive aimed to achieve was the disintegration of Dionysiac tragedy, a profound experience in Socrates' own life compels us to ask whether the relationship between Socrates and art is necessarily and exclusively antithetical, and whether the birth of an 'artistic Socrates' is something inherently contradictory.

This is similar to what Nietzsche has in mind when putting forward the idea of tragic knowledge.

${ }_{124}$ Nietzsche, GS, 151.

${ }^{125}$ Nietzsche, WP, 616 (1885-1886). 
the scepticism that he attributes to Kant. ${ }^{126}$ Nietzsche draws a two-pronged attack on such scepticism. The two prongs are the practical and the theoretical. Firstly, Nietzsche maintains that it is not practically possible to live with the scepticism of the appearance/reality divide:

Against Kant, it must always be further objected that, even if we grant all of his propositions, it still remains entirely possible that the world is as it appears to us to be. Furthermore, this entire position is useless from a personal point of view; no one can live in this skepticism.

We must get beyond this skepticism; we must forget it! How many things do we not have to forget in this world! ${ }^{127}$

This is the metaphysical indifferentist response made to the possibility of scepticism in "On Truth and Lies". Secondly, however, this practical solution must be met with a theoretical solution if Nietzsche is to properly overcome the separation of the theoretical and the practical that he attributes to Kant. In order to overcome this division Nietzsche must show that our human beliefs can attain epistemic status. That Nietzsche desires and effects such a solution can be most readily witnessed from his rejection of the sceptical nihilist. Nietzsche describes the nihilist as "a man who judges of the world as it is that it ought not to be, and of the world as it ought to be that it does not exist." 128 Scepticism is a form of nihilism, in Nietzsche's view, because it induces in man the feeling of being volitionally ineffective in one's world. It separates the world as it is from the world as it ought to be. The world as it ought to be is articulated by our specifically human interests and ideals. For the nihilist, however, the world is radically divorced from and incommensurate with our ideals. In this way, nihilism forges an opposition of self and world. That Nietzsche desires to reconcile factualism and normativity is further suggested by his criticism of the

\footnotetext{
${ }^{126}$ Nietzsche, "The Philosopher", paragraph 84.

${ }^{127}$ Ibid.
} 
Stoics. He maintains that the Stoics projected their own ideals (normative) onto the world without attempting to constrain these ideals with scientific research. He argues that the Stoics projected their own ideal as an extra-perspectival fact about the world. Thus Nietzsche argues that what the Stoics called nature was in fact "a great and unending glorification and universalization of Stoicism." 129 However, in Beyond Good and Evil, Nietzsche maintains that philosophy has always projected its ideals onto the world. He states that "every great philosophy to date has been: the personal confession of its author, a kind of unintended and unwitting memoir". ${ }^{130}$ Thus Nietzsche argues that it is always an ethical ideal that inspires a philosopher. He states:

Whenever explaining how a philosopher's most far-fetched metaphysical propositions have come about, in fact, one always does well (and wisely) to ask first: 'What morality is it (is he) aiming at?' Thus I do not believe that an 'instinct for knowledge' is the father of philosophy, but rather that here as elsewhere a different instinct has merely made use of knowledge (and kNOwledge) as its tool. [--] all the instincts have practised philosophy, and [---] each one of them would like only too well to represent itself as the ultimate aim of existence and as the legitimate master of all other instincts. ${ }^{131}$

Moreover Nietzsche suggests both that practical interested concerns have initiated philosophical investigation and that these practical concerns can lead to knowledge.

The normative activity of philosophy, according to him, involves a selective focussing on the world through the optics of the ideal. Thus he argues that our interested or normative engagement with the world involves focusing on those particular aspects of reality that best serve our needs and render us volitionally effective in the world. From this we can see that, for Nietzsche, we harbour

\footnotetext{
${ }^{128}$ Nietzsche, WP, 585A (1887-1888).

${ }^{129}$ Nietzsche, BGE, 9.

${ }^{130}$ Ibid., 6.

${ }^{131}$ Ibid.
} 
anthropomorphic ideals that guide our interested inquiry into the world. It has been suggested in the secondary literature on Nietzsche that these ideals falsify the true nature of reality. This is often extended into the view that Nietzsche thinks that we rank interpretations according to their practical value for life only. This further implies that our interpretations of the world are mere interpretations and thus that no one interpretation is epistemically better than another. In so doing, this view maintains that Nietzsche is not concerned with the truth of interpretations. However, it would seem, contrary to this view, that Nietzsche does in fact think that some interpretations are epistemically better than others. ${ }^{132}$ Thus, for Nietzsche, the "ought to be", or the ideal through which we view the world, is ultimately valuable to the extent that it reveals some aspect of the world to us. In his view, our normative engagement with the world is ultimately valuable in disclosing the truth about the world:

On the other hand, it is only this desire "thus it ought to be" that has called forth that other desire to know what is. For the knowledge of what is, is a consequence of that question: "How? is it possible? why precisely so?" Wonder at the disagreement between our desires and the course of the world has led to our learning to know the course of the world. ${ }^{133}$

From the above we can now see that the "ought to be" and the "is" share a reciprocal relationship. The "ought to be" captures our specifically human mode of being in the world. We experience ourselves, according to Nietzsche, as volitional agents pursuing the fulfillment of our ideals. The extent to which these ideals meet with resistance reveal the nature of the "is". Thus, norms and facts are not, in Nietzsche's view, irreconcilable and incompatible opposites. Rather they constrain one another. This

\footnotetext{
${ }^{132}$ In chapter four we will see that the ranking of perspectives on this level is decided by how well they explain the phenomena.

${ }^{133}$ Nietzsche, WP, 333 (1883-1888).
} 
relationship between norms and facts indicates Nietzsche's internal realist viewpoint, which claims that our anthropomorphic practices are rooted within and constrained by the world. It is in this way that Nietzsche overcomes the opposition of self and world. We are denied any extra-cognitive or extra-human vantage point from which we can survey the nature of reality. All theoretical pursuits must be carried out, in Nietzsche's view, from our embodied and immersed practical engagement in the world. Nietzsche's internal realism thus emerges from the collapse and ruin of the idealist/realist framework of previous philosophies. With the collapse of such an oppositional mode of thought Nietzsche is successfully able to abandon scepticism. It is at this point that we can return to his mature writings where his internal realist solution to the problem of the opposition of self and world is developed further. I will embark upon this enterprise by focusing, in chapter four, on the metaphysics that emerges from his perspectival theory of knowledge. I will conclude this chapter, however, by citing Beyond Good and Evil where we witness Nietzsche's rejection of metaphysical opposites:

However much value we may ascribe to truth, truthfulness, or altruism, it may be that we need to attribute a higher and more fundamental value to appearance, to the will to illusion, to egoism and desire. It could even be possible that the value of those good and honoured things consists precisely in the fact that in an insidious way they are related to those bad, seemingly opposite things, linked, knit together, even identical perhaps. Perhaps! ${ }^{134}$

\footnotetext{
${ }^{134}$ Nietzsche, BGE 2. Cf. HAH, 1.
} 


\section{Chapter Four}

\section{The Will to Power}

\subsection{Introduction}

The principal aim of this chapter is to address the manner in which Nietzsche's epistemology facilitates an engagement with metaphysics that he thinks is disallowed by Kant's division between constitutive knowledge and regulative belief. In previous chapters I argued that Nietzsche's perspectivism is compatible with a realist view. However, I did not examine his positive metaphysics. In this chapter I shall take up this issue with regard to the doctrine of the will to power. Nietzsche's will to power thesis puts forward the view that forces motivated by the desire for power are the ultimate constituents of reality. Moreover, he claims that both self and world are composed of these forces. As this is considered to be a contentious doctrine amongst both Nietzsche's supporters and detractors alike, it will be necessary that I prelude any discussion of the metaphysics of the will to power with a discussion of Nietzsche's justification of the doctrine. In order to address the pertinent issues with regard to both the justification and metaphysical content of the doctrine I will divide this chapter into two parts. The first part will focus on the issue of the compatibility of the will to power with Nietzsche's perspectival theory of knowledge. The aim here is to demonstrate Nietzsche's view that it is possible to put forward a true metaphysical thesis from within an anti-foundationalist conception of knowledge. In so doing, we will see the manner in which Nietzsche adopts Kant's epistemic turn in a way that allows him to overcome the scepticism that he attributes to Kant. 
The second part of the chapter will address the content of the will to power thesis in an attempt to pinpoint the specific reasons informing Nietzsche's 'force' metaphysics. This will involve an examination of the will to power as an instance of conceptual change. In so doing, we will see that Nietzsche puts forward the doctrine as an explanatory realist thesis. At this point we will see that Nietzsche adopts a regulative metaphysics that seeks to overcome the opposition of self and world. Moreover, I want to demonstrate that Nietzsche appeals to a standard of epistemic merit by proposing that some claims are epistemically more worthy than others.

In both parts one and two of this chapter my principal interest lies in the epistemic commitments informing Nietzsche's doctrine of the will to power. We will see that the epistemology that guides the presentation of the doctrine is a strong one that facilitates his ultimate project of reconciling self and world by fostering the idea that there is one world of which we can have adequate knowledge. It will also be indicated that it is precisely this epistemic aspect of the doctrine that Nietzsche unqualifiedly endorses whilst leaving open the question whether the actual metaphysical content of the doctrine may be subject to alteration. Thus, although the question of the ultimate cogency of the actual metaphysics of the will to power is beyond the scope of this analysis, I will argue that its epistemic commitments implement a framework according to which such a project may be successfully undertaken. With these points in mind I will now turn to the first part of this project. 


\section{Part One}

Nietzsche's Justification of the Will to Power

\subsection{The Compatibility Issue}

We saw in chapter two that Nietzsche's perspectivism rejects the metaphysical correspondence theory of truth in favour of an anti-foundationalist conception of knowledge. However, it has been argued by those who wish to save Nietzsche from the clutches of metaphysical realism and the metaphysical and epistemological foundationalism that ensues from it, that the metaphysical doctrine of the will to power is a thorn in Nietzsche's overall philosophical project. Commentators argue that the doctrine of the will to power either needs to be eliminated and discounted as untrue, or, that it is to be understood as an example of Nietzsche's philosophical wavering between a metaphysical and anti-metaphysical position. Thus the view has been that the metaphysical doctrine of the will to power is incompatible with Nietzsche's perspectival anti-foundationalist conception of knowledge. This consideration derives from the view that if the will to power is intended to be a true metaphysical thesis, then, it represents a foundationalist doctrine and thus an extraperspectival claim to knowledge. Implicit in this claim is the view that Nietzsche's perspectivism does not facilitate an engagement with metaphysics. Few commentators, then, have attempted to read the doctrine of the will to power as an important vehicle in Nietzsche's overcoming of metaphysical realism and thus as 
working in tandem with his perspectivism. ${ }^{1}$ Two dominant lines of argument have surfaced in the secondary literature regarding this issue. Both arguments are designed to weaken the significance of the will to power thesis within Nietzsche's philosophy as a whole. The first argument is the textual argument that claims that Nietzsche does not articulate the will to power thesis as a true metaphysical doctrine in the published writings. The second argument is the philosophical argument, which claims that the will to power thesis is incompatible with Nietzsche's perspectivist epistemology. Although I am principally concerned to address the philosophical argument, it is necessary that I first address the textual argument. For my engagement with the philosophical argument and the issue of the justification of a metaphysical thesis, can only be properly meaningful if it can be shown that Nietzsche puts forward a metaphysical thesis in the first instance. I will address each of these arguments in turn. In so doing, I will suggest that the two arguments are flawed, and moreover, that Nietzsche's will to power thesis represents, contrary to these two views, an important component in his philosophical enterprise. With this in mind, I will now proceed to examine the textual argument.

\subsection{The Textual Argument}

The textual issue centers round the question of whether Nietzsche intends his articulation of the metaphysical doctrine of the will to power to be true or a mere

\footnotetext{
${ }^{1}$ John Richardson attempts to demonstrate the importance of the doctrine of the will to power in relation to Nietzsche's perspectivism. However, Richardson sees the will to power as preceding and grounding Nietzsche's perspectivism. The difficulty with such an approach is that it fails to show how Nietzsche arrived at the doctrine. In so doing, the will to power appears as an unjustified foundationalist thesis. Moreover, Richardson's interpretation takes little account of, what we will see is, Nietzsche's concern with philosophical method. [See John Richardson, Nietzsche's System, (Oxford: Oxford University Press, 1996), especially chapter 1.2].
} 
hypothesis. With regard to this issue, Maudemarie Clark claims that the metaphysical version of the will to power as it appears in the published writings is not presented as a true doctrine but rather as one that Nietzsche would like to be true. This, however, is an unconvincing argument. In effect it claims that Nietzsche who puts forward an anti-foundationalist epistemology is, in his weaker moments, a foundationalist thinker at heart and, thus, that he is an anti-foundationalist against his instincts. Clark appeals to Beyond Good and Evil, $36^{2}$ and the surrounding passages to support her claim. In this section Nietzsche puts forward the hypothesis "that nothing real is 'given' to us apart from our world of desires and passions, assuming that we cannot ascend or descend to any 'reality' other than the reality of our instincts". This develops into the conjecture that there is only one form of causality operative in the world and that is the action of Will upon Will:

The question is ultimately whether we really recognize that the will can effect things, whether we believe in the causality of the will: if we do (and to believe in this is basically to believe in causality itself) we must experiment to test hypothetically whether the causality of the will is the only causality; A 'will' can have an effect only upon another 'will', of course, and not upon 'matter' (not upon 'nerves', for example): one must dare to hypothesize, in short, that wherever 'effects' are identified, a will is having an effect on another will - and that all mechanical events, in so far as energy is active in them, are really the energy of the will, the effect of the will. ${ }^{3}$

Clark argues that if we interpret this section of BGE in the context of the passages that surround it, then we cannot with sincerity claim that Nietzsche commits himself to this metaphysical form of the will to power. She maintains that an examination of these surrounding passages will reveal that Nietzsche actually undermines the metaphysical version of the doctrine. Furthermore, Clark argues that acceptance of the doctrine as it appears in BGE, 36 would involve attributing to Nietzsche a priori

\footnotetext{
${ }^{2}$ In order to avoid cluttering the text here I will refer to Beyond Good and Evil as BGE.

${ }^{3}$ Friedrich Nietzsche, Beyond Good and Evil, translated by Marion Faber, (Oxford: Oxford University Press, 1998), 36. Hereafter cited as BGE.
} 
knowledge of the Will as an indubitable knowledge in a similar fashion to the supposed certainty and indubitable character of Descartes' 'thoughts'. According to Clark this would merely serve, contrary to Nietzsche's aims, to devalue the world of empirical experience. Thus she argues that the claims made in BGE, 36 are in conflict "with Nietzsche's denial in BG 16 that there are "immediate certainties," including 'I think' or 'I will"'4. It is also incompatible, according to Clark, with Nietzsche's criticism in BGE, 19 of philosophers, like Schopenhauer, who "speak of the will as if it were the best-known thing in the world". I will address the issue of whether Nietzsche puts forward the metaphysics of the will to power as articulated in BGE, 36 as an a priori doctrine in the next section where I will address his consideration of the issue of philosophical method. For the present I am concerned to establish that there are, contrary to Clark's claim, textual reasons for thinking that Nietzsche puts forward the metaphysical doctrine of the will to power as a true thesis. If it can be shown that the metaphysical version of the will to power is put forward as a true doctrine, then greater attention will have to be given to Nietzsche's metaphysics than Clark's reading allows. Let me, then, present the argument of BGE, 36 and Clark's estimation of it.

Clark's argument relies on her claim that, despite the suggestions made in BGE, 36, Nietzsche rejects both foundationalism and the causality of the Will. She maintains that their rejection takes place in both the passages surrounding BGE, 36 and other passages where Nietzsche discusses the concept of causality. In such passages, she contends, Nietzsche undermines the presentation of the will to power

\footnotetext{
${ }^{4}$ Maudemarie Clark, Nietzsche on Truth and Philosophy, (Cambridge: Cambridge University Press, 1994), p. 214.
} 
thesis as a true metaphysical doctrine. However, it can be seen that in these passages

Nietzsche, contrary to Clark's claim, merely rejects foundationalism and not the causal efficacy of the Will. I will cite two relevant passages for the convenience of the reader. The first passage is from The Gay Science, 127:

Aftereffects of the most ancient religiosity. - Every thoughtless person supposes that will alone is effective; that willing is something simple, a brute datum, underivable, and intelligible by itself (my italics). He is convinced that when he does something - strike something, for example, - it is he that strikes, and that he did strike because he willed it. He does not see any problem here; the feeling of will seems sufficient to him not only for the assumption of cause and effect but also for the faith that he understands their relationship. He knows nothing of the mechanism of what happened and of the hundredfold fine work that needs to be done to bring about the strike, or of the incapacity of the will in itself to do even the tiniest part of this work. The will is for him a magically effective force; the faith in the will as the cause of effects is the faith in magically effective forces. ${ }^{3}$

The second passage is from $\mathrm{BGE}, 19$ :

Philosophers tend to speak about the will as if everyone in the world knew all about it; Schopenhauer even suggested that the will is the only thing we actually do know, know through and through, know without additions or subtractions. But I continue to think that even in this case Schopenhauer was only doing what philosophers simply tend to do: appropriating and exaggerating a common prejudice. As I see it, the act of willing is above all something complicated, something that has unity only as a word - and this common prejudice of using only one word has overridden the philosophers' caution (which was never all that great anyway).

These passages articulate a view similar to that outlined in BGE, 36. Of interest to us

here is that in these passages Nietzsche is not rejecting the causality of the Will but rather he is rejecting, what he considers to be, the incomplete analysis of the Will. Of the above two passages Peter Poellner remarks that

If we follow the line of thought set out in these passages, Nietzsche's criticism is directed nor at the claim that we are acquainted with efficacy in volition, nor (a fortiori) against the common belief that we have a genuine idea, a concept, of causal power, but merely against false philosophical analyses or descriptions of the former. ${ }^{6}$

\footnotetext{
${ }^{5}$ Friedrich Nietzsche, The Gay Science, translated by Walter Kaufmann, (New York: Vintage Books, 1974), 127.

${ }^{6}$ Peter Poellner, "Causation and Force in Nietzsche" in B. Babich (ed.), Nietzsche, Epistemology, and Philosophy of Science: Nietzsche and the Sciences II, (Great Britain: Kluwer Academic Publishers, 1999), p. 291.
} 
In particular, Nietzsche criticizes the view that the Will is something "given", simple and intuitively known. Thus it seems that what he is attacking in the above cited passages is Schopenhauer's view that we have unmediated intuitive knowledge of the Will. Schopenhauer argues that the Will is immediately known as "the inner nature of the world"?

[---] the concept of will is of all possible concepts the only one that has its origin not in the phenomenon, not in the mere representation of perception, but which comes from within, and proceeds from the most immediate consciousness of everyone. In this consciousness each one knows and at the same time is himself his own individuality according to its nature immediately, without any form, even the form of subject and object, for here knower and known coincide. ${ }^{8}$

The Will is, for Schopenhauer, the knowable thing-in-itself that is made manifest in various phenomenal instantiations that are, in his view, "quite different" from the nature of the Will itself. ${ }^{9}$ His understanding of the Will is, according to Nietzsche, an appeal to extra-conceptual and intrinsically credible facts that make up the foundationalist appeal to knowledge. ${ }^{10}$ However, the will to power, contrary to Schopenhauer's foundationalist conception of the Will, is defined according to its context. That is to say that the will to power is given content only in a particular context and is defined by its context. As such, it is not something "given" independently of the form in which it appears. Richard Schacht captures this aspect of Nietzsche's thinking in the following:

\footnotetext{
${ }^{7}$ Arthur Schopenhauer, The World as Will and Representation, Volume 1, translated by E. F. J. Payne, (New York: Dover, 1969), p. 112. Hereafter cited as WWR, I.

${ }^{8}$ Ibid.

${ }^{9}$ Ibid. For Schopenhauer's claim that we have unmediated acquaintance with the Will see also p. 505.

${ }^{10}$ See Michael Williams, Groundless Belief. (Princeton: Princeton University Press, 1999), p. 70 for this characterization of foundationalism.
} 
[---] 'power' for Nietzsche is neither the name of a single game nor that of a family changing through births and deaths, any more than is 'winning' in the domain of ordinary games. "Winning' might be what games are all about (though this may of course be disputed); but what it is to win or play well at one may be very different from what it is to do so at another. And so with respect to Nietzsche's understanding of power and his conception of the struggle for power. ${ }^{11}$

Schacht maintains that, for Nietzsche, there is no such thing as the will to power "apart from any specific context in terms of which its enjoyment can be distinguished from a relative lack of it, and which can be contested for as such." 12 In this way, Nietzsche rejects the foundationalist implications of Schopenhauer's appeal to the Will and the possibility of non-propositional or extra-perspectival knowledge. Despite his rejection of foundationalism, however, he upholds his thesis regarding the causality of the Will. Both Nietzsche's rejection of the foundationalist conception of the Will as something immediately known, and acceptance of the causality of the Will can be seen from BGE, 19. Here Nietzsche is at pains to demonstrate that the Will is not so simply known but rather that it is "something complicated, something that is a unity only as a word". ${ }^{13}$ I will not address in detail what causal efficacy of the Will entails. However, it is sufficient to note here that Nietzsche upholds the causal efficacy of the Will as a complex phenomenon that involves both the affect of commanding and the affect of obeying. The causal efficacy of the Will involves, Nietzsche suggests, a hierarchical relationship between commanding and obeying wills. He states that "A person who wills: this person is commanding a Something in

\footnotetext{
${ }^{11}$ Richard Schacht, Nietzsche, (London: Routledge and Kegan Paul, 1983), p. 222.

${ }^{12}$ Ibid., p. 223.

13 Nietzsche explicitly rejects self-justifying concepts in BGE, 20 in favour of conceptual interrelatedness:

That individual philosophical concepts are not something isolated, something unto themselves, but rather grow up in reference and relatedness to one another; that however suddenly and arbitrarily they seem to emerge in the history of thought, they are as much a part of one system as are the branches of fauna on one continent.
} 
himself that obeys, or that he thinks is obeying." ${ }^{.14}$ In so explaining the phenomenon of Willing, Nietzsche actually restates the thesis outlined in BGE, 36 that wills only act upon wills and not upon matter. On the basis of this it now seems that Clark's claim that Nietzsche undermines the metaphysical doctrine of the will to power in the passages surrounding BGE, 36 is mistaken. For we can see that Nietzsche thinks, contrary to Clark's view, that he can uphold his thesis regarding the causal efficacy of the Will outlined in BGE, 36 whilst still rejecting the foundationalist implications of Schopenhauer's appeal to the Will. Clark also pays little attention to BGE, 12 where Nietzsche praises Boscovich. As we will see in part two of this chapter, Nietzsche's will to power metaphysics emerges from his engagement with Boscovich. Thus it now seems that we cannot so readily dismiss the doctrine of the will to power as merely an expression of Nietzsche's own values. Rather, it seems that Nietzsche articulates the will to power as a true metaphysical doctrine.

Having established that Nietzsche puts forward a metaphysical thesis, it must now be shown that he is entitled to do so from within the parameters of his perspectival theory of knowledge. In so doing, the remaining sections of part one of this chapter will address the philosophical argument against the cogency of the will to power thesis. This argument is intertwined with the issue of Nietzsche's perspectivist response to metaphysical realism that I addressed in chapter two. The philosophical argument claims that if Nietzsche intends the will to power thesis to be a true doctrine about the nature of reality, then he is engaging in foundationalist metaphysics and thus in metaphysical realism. As such, objectors to the will to power thesis claim that Nietzsche's metaphysics is incompatible with his anti-foundationalist perspectival

\footnotetext{
${ }^{14}$ Nietzsche, BGE, 19.
} 
theory of knowledge. In addressing this issue I will examine the extent to which it can

justifiably be said that Nietzsche's metaphysical doctrine of the will to power represents, contrary to the philosophical argument, an overcoming of metaphysical

realism. Thus I will argue that Nietzsche's metaphysics is not only compatible with his perspectivism but that his perspectivism facilitates the making of objective metaphysical claims about the nature of reality.

Although I explored the issue of metaphysical realism in chapter two it is necessary that I re-examine it here in the specific context of the issues that are pertinent to Nietzsche's proposal of the will to power thesis. This will contextualize his motivation in putting forward a true metaphysical thesis and aid my attempt to treat the will to power as a substantial doctrine rather than an inert hypothesis with little interest in its own truth status. ${ }^{15}$ Thus I will proceed by once again setting up the

${ }^{15}$ Commentators such as George Stack and Bernd Magnus argue, in a somewhat similar vein to Maudemarie Clark, that the doctrine of the will to power is not to be interpreted as a "true" metaphysical doctrine. They claim that the will to power is not designed to capture the truth about the world. Both Stack and Magnus interpret the will to power in relation to Nietzsche's views on the philosophy of ressentiment. They argue that the will to power is to be understood in the context of Nietzsche's desire to overcome the negative life denying stance of ressentiment in favour of an affirmative stance. In this context, they maintain that the will to power is to be understood as an affirmative counter-myth. As such, the argument goes, it is not intended to make any metaphysical claims. Stack argues that the will to power

[--] is a hypothetical argument based upon premises that are considered fallacious or fictional. There is no demonstration that there is a will to power; the conception is defended in terms that indicate that the entire conception is fictional. That a will to power acts through all things is not a "fact" (especially in the light of Nietzsche's denial of facts) and it is not a "theory". It is an elaborately constructed counter-myth. ${ }^{15}$ [George Stack, "Kant, Lange and Nietzsche" in K. Ansell-Pearson (ed.), Nietzsche and Modern German Thought, (London: Routledge, 1991), p. 293]. See also Bernd Magnus, "Eternal Recurrence" in NietzscheStudien, 1979.

In response to this reading, it is unclear to me how an hypothesis whose fictional character is obvious could induce the type of affirmation that Nietzsche desires. It seems to me that an hypothesis of any kind can only induce such existentialist consequences if it considered to be a true thesis. Furthermore, Stack appears to conflate the "hypothetical" character of the doctrine with fictionality or untruth. It is not clear how something whose status is hypothetical is automatically dismissed as untrue. It can arguably be claimed that Nietzsche's appeal to myth is not an appeal to untruth in an epistemic sense. This can be discerned from as early as the unpublished "The Dionysian World View" where, when Nietzsche speaks of the unity of the Apolline and the Dionysiac he no longer speaks of a juxtaposition of semblance and untruth, but rather of "probability" which, he claims, is a "sign of truth". [See "The 
problematic of metaphysical realism in order to draw out the specific elements to which the will to power thesis is designed to respond, and the requirements that Nietzsche must meet if he is to properly overcome it. In so doing, my guiding motivation will be to argue that the doctrine of the will to power is compatible with Nietzsche's perspectivism to the extent that the former derives from the latter. It is to this problematic that I now turn.

\subsection{Metaphysical Realism}

We saw in chapter two that, for Nietzsche, metaphysical realism assumes either a cognitivist or non-cognitivist guise. The cognitivist maintains that reality as it is in itself is cognitively accessible to us whilst the non-cognitivist denies this possibility. The cognitivist position is a foundationalist one that claims that the justification of our epistemic claims resides in "confrontations" with the world. This type of realism maintains that "the correctness of a representing or system of representings consists in its adequacy to a world (i.e., to that which it represents). ${ }^{16}$ The distinguishing feature of this type of realist lies in their view that "adequacy to the world is the criterion of correctness for our representings." ${ }^{\text {17 }}$ In so doing, the issue of correctness is said to be determined from "outside" our internal perspectival practices of justification. For the foundationalist, then, metaphysics precedes epistemology to the extent that the nature of reality itself is taken to be the test and standard of adequate knowledge. The cognitivist metaphysical realist considers the world to be radically theory-

Dionysian World View" in The Birth of Tragedy and Other Writings, translated by Ronald Speirs, (Cambridge: Cambridge University Press, 1999), p. 133]. 
independent and thus only captured adequately from an extra-perspectival God's Eye

View. However, this account of justification ultimately collapses with the demise of the viability of the God's Eye View. In response, the non-cognitivist metaphysical realist, which Nietzsche associates with Kant in particular, wavers between the desire to posit a realist constraint to our epistemic claims whilst simultaneously avoiding the incoherency of foundationalism. In response to this difficulty, the non-cognitivist adopts a theory-internal conception of justification in place of the extra-perspectival conception put forward by the cognitivist metaphysical realist. For the noncognitivist, epistemology precedes metaphysics to the extent that it seeks to emphasize the role of the knower in the justification of our epistemic claims. In so doing, however, the non-cognitivist is faced with the dilemma of explaining how our internal practices of justification adequately capture the nature of reality. The problem is, then, how to avoid confinement within one's conceptual scheme. Kant attempts to escape such confinement by appealing to the unknowable thing-in-itself. In this way, he attempts to retain an element of constraint from a realist core. Thus Kant is unwilling to take the idealist route in response to the dilemma. He attempts to retain a realist constraint without appealing to the God's Eye View conception of justification by positing the thing-in-itself as an object of thought rather than as an object of knowledge:

[---] though we cannot know these objects as things in themselves, we must yet be in position at least to think them as things in themselves; otherwise we should be landed in the absurd conclusion that there can be appearance without anything that appears. [my italics] ${ }^{18}$

\footnotetext{
${ }^{16}$ J. F. Rosenberg, One World and Our Kmowledge of It: The Problem of Realism in Post-Kantian Perspective, (Dordrecht, Holland: D. Reidel Publishing Company, 1980), p. 89. Rosenberg calls this type of realism "Criteriological Realism".

${ }_{17}$ lbid., p. 113.

${ }^{18}$ Kant, Critique of Pure Reason, translated by Norman Kemp Smith, (London: Macmillan Education Company, 1929), Preface to Second Edition, Bxxvi. Hereafter cited as CPR.
} 
However, as we have seen, it is Nietzsche's view that Kant's attempt to retain a realist constraint ultimately fails because the thing-in-itself is both ineffable and incognizable. By adopting the view that ultimate reality is theory-independent in a similar fashion to the cognitivist, Kant's appeal to a realist core, as interpreted by Nietzsche, lacks the necessary power to act as a realist constraint. ${ }^{19}$ Thus Nietzsche maintains that Kant is forced to operate within an appearance/reality distinction that distinguishes how objects are for us from how they are in themselves. This distinction represents, in Nietzsche's view, an oscillation between a foundationalist response and an idealist response to the problem of the compatibility of maintaining a realist constraint whilst adopting a theory-internal conception of justification. If one accepts this particular historically rooted reading of Kant, it can arguably be claimed that Kant inadvertently leans towards idealism when he claims that the thing-in-itself can only be defined negatively (that is, as non-temporal and non-spatial). This suggests that the world as it is independently of the conditions of our knowledge (conceptual imposition) is metaphysically indeterminate. ${ }^{20}$ The world is only rendered determinate and given a positive definition when we impose concepts and a spatiotemporal setting. In this way it can be said of the Kantian metaphysical realist that "To a degree we create the world we live in."21 In this way, as we saw in chapter one, Nietzsche maintains that Kant's constitutive conception of empirical knowledge

\footnotetext{
${ }^{19}$ See, for example, Friedrich Nietzsche, Human, All Too Human, translated by Marion Faber and Stephen Lehmann, (London: Penguin, 1994), 16. Hereafter cited as HAH.

20 Both Nietzsche and Schopenhauer interpret Kant's account of transcendental conditions of knowledge in a metaphysical sense to the extent that they consider Kant's epistemic conditions to be metaphysically constitutive of the world. Thus Schopenhauer claims that Kant's philosophy should be considered as a form of Berkeleian empirical idealism and that Kant was in error in attempting to reject the Berkeleian interpretation of his writings. See Schopenhauer, WWR, I, pp. 434-5.

${ }^{21}$ Michael Devitt, Realism and Truth, (Princeton: Princeton University Press, 1997), p. 60.
} 
that Kant's idealist leanings, coupled with the failure of the thing-in-itself to provide the sought after realist constraint, deliver the non-cognitivist into the hands of the radical sceptic whereby as knowers we are confined within our internal practices of justification. ${ }^{23}$ This confinement leaves open the possibility that our knowledge may differ radically from how the metaphysical world is, unbeknownst to us, in itself. ${ }^{24}$ In turn this sceptical possibility induces an opposition between self and world by reinstating the cognitivist's Myth of the Mind Apart. The following description captures this problematic:

The Myth is a polymorphic one, but its central element is the supposition that the world is a thing which is ontologically alien to us as we are, to us as representers and as knowers - a thing which stands somehow outside us, and which challenges us to bring the inner life of our thinkings into harmony with it. ${ }^{25}$

From this we can see that Kant, as interpreted by Nietzsche, is caught in the dilemma that he can retain a realist constraint only by accepting foundationalism. Similarly, he can avoid foundationalism only by relinquishing a realist constraint and adopting a form of sceptical idealism.

In what follows I will argue that Nietzsche's will to power thesis overcomes both the cognitive and non-cognitive forms of metaphysical realism by rejecting the

\footnotetext{
${ }^{22}$ Thus the thing-in-itself is deemed to be an indeterminate thing that can be metaphysically carved up in a multiplicity of ways. Hilary Putnam captures this aspect of metaphysical realism when he states:

Now, the classical metaphysical realist way of dealing with such problems is well known. It is to say that there is a single world (think of it as a piece of dough) which we can slice into pieces in different ways. [Hilary Putnam, The Many Faces of Realism, (LeSalle, Illinois: Open Courh 1991), p. 19. Hereafter cited as MFR].

${ }^{23}$ See, for example, Friedrich Nietzsche, Twilight of the Idols, translated by Duncan Large, (Oxford: Oxford University Press, 1998), IV.3 for Nietzsche's equation of Kant's retention of the thing-in-itself with scepticism. [Hereafter cited as Twilight].

${ }^{24}$ This sceptical possibility is articulated by Kant himself when he says that a non-sensible intuition of the noumenal world (as the thought of the thing-in-itself) would constitute

[-] a field quite different [my italics] from that of the senses [--] a world which is thought as it were in the spirit (or even perhaps intuited) and which would therefore be for the understanding a far nobler, not a less noble, object of contemplation. (Kant, CPR, A250).
} 
foundationalist implications of the former and the sceptical idealist implications of the latter. In so doing, I will argue that Nietzsche puts forward the metaphysics of the will to power as a perspectivist objective truth. I will take objective truth in this sense to be something that is true within human perspectives rather than something that is true outside all human perspectives. ${ }^{26}$ In so doing, I aim to respond to a criticism that is often levied at Nietzsche's doctrine of the will to power. This criticism charges that the will to power is incompatible with an anti-foundationalist conception of knowledge. The objection centers round the claim, mistaken I believe, that the will to power thesis, if true, is an a priori doctrine that attempts to capture the world independently of the perspectival range of our knowledge. Implicit in this objection is the idea that only a foundationalist view facilitates the making of objective (adequate) metaphysical claims about the nature of reality. I will show, contrary to this objection, that by combining a rejection of the metaphysical realist theory-independent conception of world with Kant's prioritization of epistemology over metaphysics, Nietzsche is entitled to make objective metaphysical claims from within an antifoundationalist and perspectival theory of knowledge. We will see that, according to Nietzsche, the world cannot denote a theory-independent thing-in-itself but rather it must be grasped under some description or other. In so doing, he can avoid the metaphysical realist idea that there is an Archimedean point "or a use of 'exist' inherent in the world itself ${ }^{27}$ independently of our choice of theory or description. Furthermore, we will see that Nietzsche succeeds in securing a realist constraint and

\footnotetext{
${ }^{25}$ Rosenberg, One World and Our Knowledge of It, p. 189.

${ }^{26}$ See Steven D. Hales and Rex Welshon, Nietzsche's Perspectivism, (Urbana: University of Illinois Press, 2000), p. 34 for a similar suggestion.

${ }^{27}$ Putnam, MFR, p. 20.
} 
overcoming sceptical idealism by putting forward the idea of adequate knowledge. He states:

There is no question of "subject" and "object," but of a particular species of animal that can prosper only through a certain relative rightness [my italics]; [----] a species grasps a certain amount of reality [my italics] in order to become master of it, in order to press it into service. $^{28}$

Moreover, we will see that Nietzsche's development of the Kantian thesis that epistemology precedes metaphysics stipulates that questions regarding the adequacy of our epistemic claims to the world are questions of correctness. ${ }^{29}$ This maintains that questions of "adequacy" are worked out from "within" a conceptual scheme rather than from an extra-perspectival position. By this I mean that questions of adequacy are not determined by extra-conceptual or extra-perspectival "encounters" with the world, but rather, that the correctness and truth of a statement is determined by justification. In this way Nietzsche can retain the notion of adequacy without commitment to either foundationalism or sceptical idealism. ${ }^{30}$ Thus, Nietzsche's view presupposes that there are strict methodological constraints on what is to be considered a worthy epistemic claim. Moreover, we will see that he justifies the making of objective metaphysical claims from within the confines of these strict epistemic parameters.

Thus, the final section of part one of this chapter will examine the manner in which Nietzsche regards the will to power as a true metaphysical thesis and how he justifies making this claim. This will involve distinguishing between the will to power

\footnotetext{
${ }^{28}$ Friedrich Nietzsche, The Will to Power, translated by Walter Kaufmann, (New York: Vintage Books, 1968), 480 (1888). [Hereafter cited as WP]. See also The Gay Science, translated by Walter Kaufmann, (New York: Vintage Books, 1974), 335, [Hereafter GS] where Nietzsche argues that knowledge of physics is a necessary pre-requisite of creation.

${ }^{29}$ See Rosenberg, One World and Our Knowledge of It, p. 114.

${ }^{30}$ Rosenberg adopts a similar view. Ibid., p. 115.
} 
as an epistemic thesis and the will to power as a metaphysical thesis. As an epistemological thesis it maintains that truth "is a word for the "will to power""31 and that interpretation is "a form of the will to power". ${ }^{32}$ The metaphysical thesis holds that "This world is will to power - and nothing besides". ${ }^{33}$ This distinction reflects what we will see are Nietzsche's two philosophical interests in proposing the doctrine of the will to power. The first involves an examination of the doctrine as a reflection on the second order issue of philosophical method and truth, whilst the second involves an analysis of Nietzsche's first order theory of forces. My examination of the epistemic aspect will reveal that the metaphysics of the will to power derives from his reflections on method and truth. However, I will delay the examination of the metaphysical thesis until part two of this chapter and restrict the present analysis to the epistemic angle of the doctrine. In so doing, we will see that Nietzsche's metaphysics is compatible with his perspectivist epistemology. With this in mind, I will now proceed to examine the will to power as an epistemic thesis.

\subsection{The Epistemological Doctrine of the Will to Power}

In treating the doctrine of the will to power as an epistemic thesis in this section I am concerned to address the incompatibility charge that I alluded to earlier. We saw that this charge maintains that Nietzsche's anti-foundationalist conception of knowledge deprives him of the right to make objective metaphysical claims. In response I will argue that Nietzsche arrives at the metaphysical doctrine of the will to power from the

\footnotetext{
${ }^{31}$ Nietzsche, WP, 552 (1887), Cf. BGE, 211.

${ }^{32}$ Nietzsche, WP, 556 (1885-1886), Cf. Friedrich Nietzsche, On the Genealogy of Morality, translated by Maudemarie Clark and Alan J. Swensen, (Indianapolis: Hackett Publishing Company, 1998), II, 12. Hereafter cited as GM.

${ }^{33}$ Nietzsche, WP, 1067 (1885), Cf. BGE, 36.
} 
point of view of what we can know and justify rather than from a desire to articulate a foundationalist metaphysics. This section, then, has two principal aims. Firstly, I want to ascertain that Nietzsche gives priority to the epistemic doctrine of the will to power. This will involve an examination of Nietzsche's claims with regard to the issue of philosophical method. Secondly, I will test the extent to which Nietzsche's reflections on method curb any pretensions to extra-perspectival conceptions of justification and truth. In so doing, I am concerned to establish my thesis that, for Nietzsche, epistemology is prior to metaphysics to the extent that metaphysical claims must be justified within the parameters of our perspectival manner of justification. Furthermore, I want to demonstrate that this allows Nietzsche to maintain a realist constraint. This realist constraint entails the idea that there is one world to which our epistemic claims are more or less adequate to the extent that we can say that

We remain free, in other words, to hold both that the correctness of our representings does not consist in their adequacy to the world and that, nevertheless, our representings are correct if and only if they are adequate to the world. ${ }^{34}$

I will achieve this aim by demonstrating the manner in which the metaphysical doctrine of the will to power is most properly understood as a perspectivist objective truth in the sense of something that is true within human perspectives rather than true outside all such perspectives. The ultimate hallmark of such objective truth will be its "coherent" character or the extent to which it is responsible for the diachronic synthesis of our individual beliefs. Rosenberg articulates the diachronic character of, what I am here calling, perspectival objective truth in the following:

${ }^{34}$ Rosenberg, One World and Our Knowledge of It, p. 113. 
[---] to make sense of the realist view that there is only one world [---] we need something more than all those time-bound, "internal", synchronic "correctnesses" which appertain to representings successively as they are elements of successive conceptual schemes. We need also an absolute sense of "correctness - a sense in which an entire system of representations can, as $a$ whole, be said to be correct or incorrect. ${ }^{35}$

By putting forward the will to power as a perspectival objective truth, we will see that Nietzsche can uphold his internal realist thesis that justification and truth are not determined by "confrontations" with the world in the manner of foundationalism whilst simultaneously maintaining a realist constraint. Thus it will be seen that Nietzsche can overcome the Kantian oscillation between foundationalism and sceptical idealism, and consequently, that he succeeds in overcoming both the cognitive and non-cognitive forms of metaphysical realism. Moreover, we will also see that the will to power is compatible with Nietzsche's perspectival conception of knowledge. This examination will then provide the basis for part two of this chapter where I will argue that Nietzsche adopts a form of explanatory realism as the principal justification of the metaphysics of the will to power. I will proceed, however, by first turning to Nietzsche's articulation of the epistemic version of the will to power.

In order to achieve my aims I will return to BGE, 36 where Nietzsche articulates the doctrine of the will to power. Here he introduces the doctrine as an experiment in method. The experiment centers round the question whether we can posit the will to power as a fundamental explanatory principle. Nietzsche is here making a plea for the principle of explanatory economy. He states:

Assuming, finally, that we could explain [my italics] our entire instinctual life as the development and differentiation of one basic form of the will (namely the will to power, as $m y$ tenet would have it); assuming that one could derive all organic functions from this will to power and also find in it the solution to the problem of procreation and alimentation (it is all

${ }^{35}$ Ibid. 
one problem), then we would have won the right to designate all effective energy unequivocally as: the will to power. ${ }^{36}$

Nietzsche maintains that his experiment regarding economy of principles is demanded by the conscience of philosophical method:

In the end, we are not only allowed to perform such an experiment, we are commanded to do so by the conscience of our method. We must not assume that there are several sorts of causality until we have tested the possibility that one alone will suffice, tested it to its furthest limits (to the point of nonsense, if you'll allow me to say so). ${ }^{37}$

BGE, 36 presents the will to power as both an epistemological and metaphysical thesis. That is, the will to power is concerned to articulate both a theory of knowledge and a metaphysical doctrine of forces. However, Nietzsche gives priority to the epistemic thesis. Elsewhere he states that the "most valuable insights are arrived at last; but the most valuable insights are methods". ${ }^{38}$ His concern with the question of method centers round the manner in which we justify our truth claims. Nietzsche's conception of an objective truth that is true within perspectives rather than an extraperspectival truth that is true outside all perspectives is reflected in his conception of the will to power as the methodological unity of both the natural and the human sciences. That Nietzsche is concerned to establish such an explanatory principle that unifies both the human and the natural sciences can be seen from Human, All Too Human where he maintains that

Historical philosophy [---] the very youngest of all philosophical methods [---] can no longer be even conceived of as separate from the natural sciences $[---]^{39}$

\footnotetext{
${ }^{36}$ Nietzsche, BGE, 36.

37 Ibid.

${ }^{38}$ Nietzsche, WP, 469 (1888).

${ }^{39}$ Nietzsche, HAH, 1.
} 
His notion of philology as the "art of reading well" also expresses this concern with method. The art of reading well, according to Nietzsche, contains "the prerequisite for a cultural tradition, for a uniform science". ${ }^{40}$ With regard to Nietzsche's understanding of science, it is to be noted that he is operating with the conception of science as Wissenschaft, which includes both the human and the natural sciences. ${ }^{41}$ In so doing, he suggests that the natural sciences are just one human perspective amongst others and not a disinterested mode of inquiry capable of attaining extraperspectival truth. It is therefore not enough, according to Nietzsche, to present the results of the natural sciences. Rather these results must be considered in the context of the other sciences. ${ }^{42}$ As a doctrine of the unity of science, the will to power is fundamentally "a view about our way of knowing the world". ${ }^{43}$ Moreover, it can be seen to follow from Nietzsche's claim, witnessed in chapter two, that we should consider as many perspectives as possible in ascertaining the epistemic weight of a belief. Thus Nietzsche's emphasis on method is an important element in his rejection of foundationalism and in his putting forward an anti-foundationalist epistemology that is compatible with metaphysical truth. Lanier Anderson captures Nietzsche's perspectivist anti-foundationalist concerns when he states that Nietzsche

\footnotetext{
${ }^{40}$ Nietzsche, The Anti-Christ, in Twilight of the Idols/The Anti-Christ, translated by R. J. Hollingdale, (London: Penguin, 1990), 59. Hereafter cited as AC.

${ }^{41}$ R. Lanier Anderson, "Nietzsche's Will to Power as a Doctrine of the Unity of Science", in Studies in History and Philosophy of Science, 25, 5 (October 1994), p. 745. Lanier Anderson brings to our attention that

Nietzsche's intellectual climate [---] had a richer conception of science than we do - one which included the human sciences, or Geistewissenschaften, as well as natural sciences.

42 This dispels the view put forward by Maudemarie Clark that Nietzsche takes the natural sciences at face value. See Clark's "On Knowledge, Truth, and Value: Nietzsche's Debt to Schopenhauer and the Development of his Empiricism", in Christopher Janaway (ed.), Willing and Nothingmess: Schopenhawer as Nietzsche's Educator, (Oxford: Clarendon Press, 1998), p. 54.

${ }^{43}$ Lanier Anderson, "Nietzsche's Will to Power as a Doctrine of the Unity of Science", p. 731.
} 
[--] wants to replace the traditional, ontological conception of the unity of science with a methodological and interpretive conception. For Nietzsche, the unity of the sciences is not located in their reducibility to a common set of laws, or in the composition of their objects from a common 'stuff', e.g., matter, but rather in a unity of method which allows them to be interpreted as a coherent whole. ${ }^{44}$

Earlier I suggested that Nietzsche's rejection of the dissociation of our knowledge from the world in the manner of the "Kantian" sceptical idealist, entails the view that the world is theory-dependent. Nietzsche's methodology introduces two constraints that ensure that all warranted truth claims will be articulated within the confines of theory. The first constraint is the methodological demand for economy of principles. Nietzsche warns us in BGE, 13 that "[---] the dictates of our method [---] demands that we be frugal with our principles". The second constraint is an empiricist demand. Nietzsche states that "Our senses are the first origin of all credibility, all good conscience, all apparent truth." 45 It is important to note here that Nietzsche is not a foundationalist empiricist to the extent that his perspectivism precludes the possibility of appealing to uninterpreted self-justifying empirical facts. We can, however, explain Nietzsche's demand for an empirical constraint by appealing to his doctrine of the unity of science. Lanier Anderson captures this notion of an empirical demand when he states that, according to Nietzsche, our theories must be constrained by the data of the various sciences. Lanier Anderson states that the results of the various sciences must act "as data for any proposed account of the unity of science, and such accounts must be evaluated as interpretations of these data". 46 This can be seen from Nietzsche's claim in Human, All Too Human, 19 that the regulative ideas that we prescribe to the world are justified for as long as they do not conflict with the

\footnotetext{
${ }^{44}$ Ibid., p. 733.

${ }^{45}$ Nietzsche, BGE, 134.

${ }^{46}$ Lanier Anderson, "Nietzsche's Will to Power as a Doctrine of the Unity of Science", p. 735.
} 
scientific results. Should the theory conflict with the results, the theory may have to be abandoned. ${ }^{47}$ Thus it seems that the results of the various sciences, in Nietzsche's view, act as an empirical constraint. This entails that the data of the various sciences are given priority over the theory of the will to power. Lanier Anderson captures Nietzsche's view when he states:

If some science gives rise to well-supported theories which cannot be understood in terms of the will to power, the proper response would not be to throw out the scientific results. On the contrary, we would be forced to admit failure in our attempt to unify the sciences under Nietzsche's doctrine. We would then try to find some other unifying principle, or, if things seemed sufficiently hopeless, give up the pursuit of ultimate explanatory economy. ${ }^{48}$

By introducing the notion of empirical constraint Nietzsche disallows a priori metaphysical speculation. It seems that we are now in a position to explain Nietzsche's description of the will to power as "The world as it is seen from the inside, [my italics] the world defined and described by its "intelligible character" would be simply "will to power" and that alone". 49 Although this passage has frequently been cited in support of the reading of the will to power as an a priori metaphysical thesis, it can now be seen that the will to power is a non-foundationalist internal realist thesis. It is internal realist to the extent that any metaphysical claims that Nietzsche makes here and expects to be taken as "true" are postulated from within the realm of theory and constrained by the data of the various sciences. However, the data themselves cannot be non-propositional sensory claims but rather they must be perspectivally oriented claims. They are perspectival in character because they are the results of particular scientific inquiry. Thus the very "data"

\footnotetext{
${ }^{47}$ This would appear to be at least one aspect of what Nietzsche calls "intellectual honesty". Cf. GS, 335.

${ }^{48}$ Lanier Anderson, “Nietzsche's Will to Power as a Doctrine of the Unity of Science”, p. 735.

${ }^{49}$ Nietzsche, BGE, 36.
} 
themselves are theory-laden. Christoph Cox captures this line of thought when he argues that Nietzsche's "empiricism" does not amount to "verificationism":

[---] Nietzsche is not a verificationist who can do away with metaphysical and theological beliefs simply by pointing to a lack of empirical evidence for them. On Nietzsche's view [---] interpretations can be criticized only on the basis of other interpretations, not by recourse to some bare, uninterpreted fact. ${ }^{50}$

This can be seen from Nietzsche's criticism of Positivism's appeal to "facts,"51 and his claim that perceptions "are already the result of [-- assimilation and equalization in regard to all the past in us; they do not follow directly upon the impression". ${ }^{52} \mathrm{Cox}$ therefore describes Nietzsche's empiricism as a "holistic empiricism" that

[---] maintains that, while all knowledge is generated out of sensuous affection, the unit of empirical significance is neither the individual sensation nor the isolated statement of fact but the theory or interpretation as a whole in which sensations and statements are lodged. ${ }^{53}$

Nietzsche's doctrine of the will to power, in the context of its concern with the methodological unity of the sciences, may, then, be described as a second order belief. A first order belief can be articulated as "beliefs about objects in the world", whilst second-order beliefs are "“epistemic,' beliefs about those beliefs". ${ }^{54}$ Williams explains this distinction as follows:

[---] since any rational system of beliefs must allow for its own change and development, and for the justification of the beliefs it contains, it is clear that such a system cannot contain only first-order beliefs but must also contain second-order beliefs about techniques for acquiring beliefs. 55

Thus second order beliefs explain how our first order beliefs "hang together". ${ }^{56}$ By opting for a coherence theory of justification of our epistemic claims Nietzsche

\footnotetext{
${ }^{50}$ Christoph Cox, Nietzsche: Naturalism and Interpretation, (London: University of California Press, 1999), p. 100-101n43.

"Nietzsche, WP, 481 (1883-1888).

52 Ibid., 500 (1885-1886).

${ }^{53}$ Cox, Nietzsche: Naturalism and Interpretation, p. 99.

${ }^{54}$ Williams, Groundless Belief, p. 106.

35 Ibid.

${ }^{56}$ Ibid.
} 
avoids appealing to foundationalist self-justifying beliefs that in turn justify the rest of our beliefs. He claims:

An isolated judgment is never "true," never knowledge; only in the connection [Zusammenhange] and relation [Beziehung] of many judgments is there any surety $[\text { Bürgschaff }]^{\text {s7 }}$

Thus the guiding principle behind the epistemological doctrine of the will to power is to demonstrate how the results of the various sciences "hang together" as a coherent whole. Nietzsche maintains that

[---] the results of science do acquire a perfect strictness and certainty in their relationship to each other [in ihrem Zusammenhange mit einander]. ${ }^{58}$

Nietzsche therefore argues for the cogency of objective truths. Such truths may be described as cross-perspectival truths that are true within a multiplicity of human perspectives. In this way, it seems that, for Nietzsche, objective truths are compatible with his perspectivist thesis. This compatibility can be further demonstrated by reflecting on Nietzsche's contextualist account of truth whereby truth is indexed to a perspective. The contextualist account maintains that standards of justification vary across and are determined by context. Hales and Welshon articulate the contextualist view in the following way:

[---] it is possible under contextualism for a proposition to be true, a person to believe it, for that person to have reasons for their belief, and for that person to still lack knowledge, even though another person may believe the same thing, have the same reasons for their belief, and have knowledge. According to DeRose, this is no different than a person standing in a yellowpainted room, saying "this room is yellow," and then walking to a gray-painted room and saying "this room is yellow." Even though they say the same thing both times, only the first utterance is true; in moving to the gray room, the context of utterance (to which "this" is sensitive) changes. According to contextualists, "know" is an indexical (like "here," "now," and "this") because the truth-sensitivity component of knowledge is indexical.

\footnotetext{
${ }^{57}$ Nietzsche, WP, 530 (1883-1888).

${ }^{58}$ Nietzsche, HAH, 19.

${ }^{59}$ Hales and Welshon, Nietzsche 's Perspectivism, p. 121.
} 
Nietzsche considers our individual truth claims to be warranted contextually. However, this is not incompatible with objective truth as defined above. This can be seen more clearly if we consider objective truth, not as something that transcends context but rather as something that is intra-contextually warranted. In other words, Nietzsche's objective truths are also contextual truths to the extent that they must be warranted in each particular context. They are objective because they are true within a multiplicity of human perspectives (in this particular case within both the human and the natural sciences). Thus, as an internal realist, any metaphysical conclusions that Nietzsche reaches using this method of inquiry will be perspectivally justified. That is, they will be non-foundationalist rather than metaphysical realist in character. However, there are two possible objections to Nietzsche's internal realist thesis that must be addressed before we can proceed with part two of this chapter. Both objections challenge the compatibility of Nietzsche's brand of realism with his perspectival notion of justification. The first objection claims that realism is not compatible with justification "from within". This objection threatens Nietzsche's retention of a realist constraint. The second objection does the same thing by threatening our one-world reading of Nietzsche. It does this by claiming that since truth is a contextual matter and so relative to a perspective or conceptual scheme, there are multiple possible worlds rather than one world that constrains our epistemic claims and to which those claims are adequate. Let me address each of these objections in turn.

The initial objection is one often levied at the coherence theory of truth. It claims that our second order truths fail to capture the world and thus that the 
coherentist, which is essentially what Nietzsche is when it comes to the question of truth, cuts justification off from the world. It is important for our purposes that Nietzsche can meet this challenge successfully. For, if the charge is correct and Nietzsche is guilty of divorcing justification and truth off from the world then he will have deprived himself of any appeal to a realist constraint that I have argued is a necessary component in his overcoming of metaphysical realism.

In response, however, Nietzsche can overcome the above objection if it can be shown that the foundationalist's notion of world is a vacuous one and that the idealist alternative is equally incoherent. Allow me to probe this a little. It seems that Nietzsche's perspectivism disallows all forms of foundationalism and appeals to nonpropositional knowledge. Michael Williams argues, correctly I believe, that any theory-independent claims regarding how the world is constituted in itself entail foundationalist appeals. ${ }^{60}$ Such claims appeal to knowledge outside of all perspectives which is, for Nietzsche, an incoherent position. Furthermore, such foundationalist appeals are epistemically impotent. Non-propositional claims to knowledge cannot play any epistemic role in the justification of our beliefs. Thus, any appeal to how the world is in itself, that is, how it is independently of any theory or description, is vacuous. Williams articulates both the objection to theory-laden truths and, what he considers to be, the fundamental emptiness and incoherence of the objection as follows:

One can become haunted by the picture of one's belief system incorporating all sorts of internal relations of justification while, as a whole, floating above the world with no point of contact. But this worry is incoherent, because the concept of 'the world' which is operative

\footnotetext{
${ }^{60}$ Michael Williams, Groundless Belief, p. 101. The foundationalist takes truth to consist in unmediated contact with the world whether in the form of pure a priori cognition or noninferential acquaintance with the sensory given. In so doing, the notion of "world" presupposed in this charge is that of a theory-independent world that may differ radically from our epistemic claims.
} 
here is completely vacuous. As soon as we start thinking of that with which belief has to make contact as congeries of elementary particles, patterns of retinal irradiation, or relational arrays of sensuous colour-patches, we are operating within some particular theory of the way the world is, and the question of how belief relates to the world no longer seems puzzling. The question can exert its paralsing effect only as long as (and indeed because) the notion of 'the world' is allowed to remain as the notion of something completely unspecifiable. ${ }^{61}$

The objection that a coherence theory cuts justification off from the world partakes in the oscillation between both the foundationalism of cognitive metaphysical realism and the sceptical idealism of the non-cognitive version. It does this by maintaining that if one rejects foundationalism then one has no alternative but to embrace idealism whereby justification is cut off from the world and all attempts to retain a realist constraint are forfeited. However, the sceptical idealist alternative is equally incoherent. It too adopts the notion of a theory-independent world. With this view we merely return to the metaphysical realist conception of the thing-in-itself. Michael Williams captures this point when he argues:

The charge that [---] justification would be cut off from 'the world' fails because either the notion of 'the world' in play here is the notion of something completely unspecifiable, an unknowable thing-in-itself, in which case the charge is unintelligible, or else we are dealing with the notion of 'the world' as it is according to some particular theory, in which case the charge is not true. ${ }^{62}$

From this we can see that Nietzsche can avoid the oscillation between foundationalism and sceptical idealism by adopting a theory-dependent conception of world. This conception of world allows Nietzsche to retain a realist constraint from within a theory-internal view of justification and truth.

It is at this point, however, that I turn to the second objection put forward by Cox. Cox argues that a theory-dependent conception of "world" leads to relativism. Cox understands Nietzsche to be making two claims. Firstly, he argues that, for Nietzsche, the concept "world" only has meaning under some description or other.

${ }^{61}$ Ibid. 
Secondly, Cox maintains that, according to Nietzsche, all perspectives are "incongruent" in the strong sense of being "incompatible" with one another. The combination of the two claims results, Cox argues, in the view that we most correctly speak of "world" in the plural rather than in the singular:

This view proceeds from the naturalistic premise that we never encounter "the world as it is in itself" but always "the world as it appears under a particular description." Because there is no comparing "a description of the world" with "the world as it is under no description at all," this latter notion turns out, at best, to be superfluous. All we ever can do is compare descriptions with other descriptions. And because there is no One True World, there is no description that could show itself to be the One true Description by "corresponding to" that World. Thus there will always be many descriptions and no single, independent world that they all describe. Each description, then, is actually a prescription that constructs a world, leaving us with no World but many worlds. ${ }^{64}$

What is most troubling about Cox's reading is his view that the various descriptions of the world are incompatible with one another. It is important for the purposes of the present analysis that this reading can be overcome because it serves to undermine my thesis in two principal ways. Firstly, it denies the idea that the world constrains our epistemic claims. It does this by entertaining the idea of a plurality of possible worlds and the consequent denial that some interpretations are more correct or adequate than others. I want to retain the notion of constraint here to facilitate my claim that Nietzsche overcomes the metaphysical realist commitment to the thing-in-itself and the related oscillation between foundationalism and sceptical idealism. For I want to uphold the thesis that, for Nietzsche, our theory-internal conception of justification is subject to a realist constraint. Secondly, by arguing that the various perspectival appropriations of the world are ultimately incompatible with one another, Cox denies the possibility of objective perspectival truths. In so doing, Cox's reading renders

\footnotetext{
62 Ibid., p. 103.

${ }^{63}$ Cox, Nietzsche: Naturalism and Interpretation, p. 156.

${ }^{64}$ Ibid.
} 
Nietzsche's perspectivism incompatible with objective truth, and consequently, with the metaphysical doctrine of the will to power. I will address each of these queries in turn. Firstly, then, the lack of a realist constraint entailed by Cox's interpretation can be seen from his claim that each "description" of the world is in fact a "prescription". ${ }^{65}$ From this it seems that Cox, in this particular instance, puts forward a constitutive reading of Nietzsche's perspectivism according to which the world is organized in multiple incompatible ways. That this entails that the world places no constraint on our perspectival truths can be further seen from Cox's claim that the possibility of a plurality of incompatible interpretations "follows not from 'the world" being too much but from its being too little" ${ }^{66}$ However, this lack of a realist constraint emerges from, what seems to me to be, Cox's conflation of "interpretation" with "the world". According to Cox's reading, the world is not metaphysically independent of the multiplicity of interpretations.

However, Cox's objection can be overcome by appealing to two particular passages from Nietzsche's writings that suggest that he is concerned to maintain the very metaphysical independence that Cox denies. The first passage is BGE, 22 where Nietzsche insists on the metaphysical independence of the world from interpretations of it. Here Nietzsche considers the physicist's notion of conformity to law as an example of bad interpretive practice. Of this interpretation Nietzsche argues that

[--] it is not a factual matter, not a "text," but rather no more than a naive humanitarian concoction, a contortion of meaning that allows you to succeed in accommodating the democratic instincts of the modern soul! [---] But, as I say, this is interpretation, not text; and someone could come along with the opposite intention and interpretative skill who, looking at the very same nature and referring to the very same phenomena [my italics] would read out of it the ruthlessly tyrannical and unrelenting assertion of power claims.

\footnotetext{
${ }^{65}$ Ibid.

${ }^{66}$ Ibid., p. 152.
} 
It is important to note that it is not a theory's status as an interpretation that Nietzsche is questioning here, but rather, it is the epistemic merit of a particular interpretation as a claim to objective truth that is at issue. This can be seen from the fact that Nietzsche refers to his own doctrine of the will to power as an interpretation whilst still presenting it as a true metaphysical thesis. ${ }^{67}$ We have already seen the manner in which Nietzsche thinks that the will to power can be awarded greater epistemic status than previous interpretations of reality due to, what he considers to be, the methodologically more scrupulous birth of his own doctrine. I will return to this issue in part two where we shall see that Nietzsche puts forward the doctrine of the will to power as an explanatory realist thesis. Here, however, I am primarily concerned to suggest that Cox's conflation of interpretation and world is misconstrued and thus to retain the notion of constraint that his reading denies. Nietzsche's desire to retain the metaphysical independence of the world from its interpretations can be further witnessed in his account of philology as the art of reading well:

Philology is to be understood here in a very wide sense as the art of reading well - of being able to read off a text without falsifying it by interpretation, without losing caution, patience, subtlety in the desire for understanding. Philology as ephexis [undecisiveness] in interpretation. ${ }^{68}$

Alan D. Schrift captures Nietzsche's argument here when he states:

[--] in his transvalued notion of philology, the world becomes a text that Nietzsche exhorts us to read well (see, for example, $H A H, 8$, where Nietzsche discusses what is needed for metaphysicians to apply the philological method established for books to "the writing of nature [die Schrift der Natur $f^{2}$ ). All the while, moreover, the philological demands of honesty and justice require that we keep the text separate from its interpretation. ${ }^{69}$

\footnotetext{
${ }^{67}$ See WP, 1067 (1885) where Nietzsche maintains "the world is will to power - and nothing besides". Cf. BGE, 36.

${ }^{68}$ Nietzsche, AC, 52.

${ }^{69}$ Alan D. Schrift, Nietzsche and the Question of Interpretation, (New York: Routledge, 1990), p. 165.
} 
Furthermore, Schrift cites a passage from one of Nietzsche's final notebooks where he states: "The lack of philology: one continually confuses the exegesis with the text and what an 'exegis'!"70 We must remind ourselves very briefly here that the fact that Nietzsche separates the world from its interpretations is not problematic for my antimetaphysical realist and anti-sceptical reading of Nietzsche. The fact that our truths are indexed to perspectives does not entail the sceptical argument that we are radically in error. Rather, it has been my contention that this sceptical scenario is dependent upon acceptance of the indeterminacy of the theory-independent notion of the thing-in-itself. With this in mind I will now turn to Cox's rejection of the possibility of objective truths.

I will begin to address Cox's claim that Nietzsche's rejection of the thing-initself entails the rejection of the possibility of objective truth by citing Cox's articulation of his argument in a series of four points:

In a general sense, the doctrine of "ontological relativity" holds: (1) that it makes no sense to give an absolute description of "what there is"; (2) that it only makes sense to say "what there is" relative to a background theory, which will have its own purposes, principles, and criteria of individuation; (3) that there exist a host of such theories, many of which are equally warranted yet incompatible with one another; and thus (4) that there is no uniquely correct "way the world is" but rather as many "ways the world is" as there are warranted theories."

Here Cox conflates objective truth with a standard that is independent of all perspectives. In so doing, he argues that theory-dependent truth leads to relativism. However, this view can also be overcome by re-examining the passage to which Cox appeals in support of his claim regarding the incompatibility of perspectives. In The Will to Power, 568 Nietzsche argues that the multiplicity of perspectives are

\footnotetext{
${ }^{70}$ Nietzsche, Nietzsche Werke, Kritische Gesamtausgabe, VIII, 3:15 [82], cited in Schrift, Nietzsche and the Question of Interpretation, p. 165.

${ }^{71}$ Cox, Nietzsche: Naturalism and Interpretation, pp. 155-6.
} 
"incongruent". Cox interprets this as a strong claim that argues for the incompatibility of perspectives. However, it is possible to read Nietzsche as making a weaker antimetaphysical realist point, which claims that the multiplicity of perspectives are nonreducible to each other. This entails the view that there is no one true extraperspectival description of the world to which all other descriptions are ultimately reducible. Moreover, the non-reducibility of perspectives does not entail their essential incompatibility. It merely stipulates that truth is essentially a contextual issue in the manner in which we outlined the contextualist thesis earlier. The doctrine of the will to power as an objective truth that is true within perspectives does not violate this clause because as an intra-contextual truth it respects the priority of context. This can be seen when we consider that the metaphysical doctrine of the will to power emerges as a doctrine of unity of the various sciences and that the justification of the doctrine is dependent upon the theory bound data of the respective sciences. This fact brings to our attention the non-reducible character of the doctrine of the will to power. The will to power as an objective perspectivist truth does not stand over and above the various sciences molding their data to the doctrine. Rather the metaphysical doctrine of the will to power emerges from within a reflection upon these data and how they hang together as a methodological unity. Thus we return to Nietzsche's concern with economy of principles. It seems that the cross-perspectival conception of objective truth, which stipulates that a thesis is objectively true if it is true within a multiplicity of human perspectives, is, despite Cox's claim to the contrary, demanded by Nietzsche's doctrine of economy of principles. 
In responding to the above objections I have shown how Nietzsche's conception of the metaphysical doctrine of the will to power, as an objective truth, is justified within the parameters of his perspectival theory of knowledge and his overall anti-metaphysical realist paradigm. Rüdiger Grimm argues that the will to power is an inclusive principle that embraces all the traditional philosophical categories of metaphysics, epistemology, axiology, anthropology etc. Thus he maintains that the characterization of the will to power "as a way of knowing"72 is only one of the many aspects of the will to power. Whilst I concur with him that the will to power does indeed embrace all of the traditional philosophical categories, it seems that, within the context of Nietzsche's anti-foundationalist and anti-metaphysical realist commitments, the will to power as a way of knowing must be prioritized. In this way, we have seen that the metaphysics of the will to power derives from the epistemic doctrine of the will to power as a reflection on philosophical method and knowledge. It is precisely in this way that Nietzsche avoids making foundationalist claims about what the world is like in itself, that is, independently of our perspectival takings. Thus the doctrine of the will to power is an objective truth to the extent that it is justified as a cross-perspectival truth and not through recourse to extra-perspectival claims to knowledge. My argument, then, has been that Nietzsche prioritizes epistemology over metaphysics. In so doing, he maintains, contrary to the cognitive metaphysical realist (foundationalist), that justification is properly understood as a theory-internal or perspectival matter. Furthermore, we have witnessed Nietzsche's view that although justification does not involve confrontations with the world it is still possible to articulate perspectival objective truths. We are now ready to proceed with an

\footnotetext{
${ }^{72}$ H. Rüdiger Grimm, Nietzsche 's Theory of Knowledge, (Berlin: Walter de Gruyter, 1977), p. ix
} 
examination of the metaphysical aspect of this doctrine. It is to this that I now turn in part two of this chapter. 


\section{Part Two}

The Metaphysics of the Will to Power

[E]very elevation of man brings with it the overcoming of narrower interpretations. (The Will to Power, 616)

\subsection{Introduction}

In part one I established that Nietzsche is justified in making metaphysical claims from within the parameters of his perspectival theory of knowledge. Thus I argued that, for Nietzsche, epistemology precedes metaphysics. We witnessed that this entails the view that our epistemic claims are justified "from within" but that their justification entails their adequacy to reality. Here I will proceed to examine Nietzsche's justification of the will to power with regard to the actual content of his metaphysics. In so doing, we will see that his ultimate justification of the will to power metaphysics is an explanatory realist justification. We will also see that this explanatory realism commits him to a form of regulative, non-dogmatic metaphysics.

These aspects of Nietzsche's doctrine will be seen more clearly by considering the will to power as an instance of conceptual change. It is this particular understanding of the doctrine that draws out Nietzsche's commitment to degrees of epistemic worthiness and his ultimate commitment to a one-world view whereby the opposition between self and world is overcome. ${ }^{73}$

\footnotetext{
${ }^{73}$ In "Homer's Contest" (1872) Nietzsche writes:

When one speaks of humanity (Humanitat), the idea is basic that this is something which separates and distinguishes man from nature. In reality, however, there is no such separation". (Friedrich Nietzsche, "Homer's Contest" included in The Portable Nietzsche, edited and translated by Walter Kaufmann, (London: Chatto and Windus, 1971), p. 32.
} 
The specific aim of this section, then, is to pinpoint the manner in which Nietzsche arrives at the metaphysical content of the will to power thesis. I will view this thesis as an instance of theory change by considering the manner in which he puts forward the metaphysical doctrine of the will to power as a "better" and thus more "adequate" explanation than that proffered by Boscovich. The notion of adequacy, or what Nietzsche calls "relative rightness", ${ }^{74}$ rebukes the idea that truth is a relative matter whereby all interpretations are deemed to be of equal epistemic merit and thus devoid of a realist constraint. However, the idea that one interpretation or conceptual scheme is warranted in overturning and replacing another requires, in Nietzsche's view, that the successor interpretation proffer a more comprehensive "explanation" of phenomena. With regard to this idea of conceptual change, the explanatory realist is subject to a "double accountability" clause. ${ }^{75}$ The clause stipulates that any attempted conceptual change on the grounds of greater explanatory coherence necessitates that the successor interpretation

Not only supply us with an account of why its predecessor broke down where it did break down, but also with an account of why its predecessor succeeded as well as it did where it did succeed. $^{76}$

Since Nietzsche considers the metaphysical doctrine of the will to power to be a successor to Boscovich's theory of forces, it will be necessary for me to show why he thinks that his account is more fruitful than that of Boscovich. Thus I must subject Nietzsche to the above principle of double accountability. I will address his fulfillment of the second requirement initially as this will shed light on his fulfillment of the first requirement. Thus I will begin by addressing Nietzsche's account of the

\footnotetext{
${ }^{74}$ Nietzsche, WP, 480 (1888).

${ }^{75}$ Rosenberg, One World and Our Knowledge of It, p. 177.

${ }^{76}$ Ibid.
} 
success of Boscovich's theory of forces. This will be followed by an account of why Boscovich, as interpreted by Nietzsche, is ultimately unsatisfactory and why Nietzsche thinks that Boscovich's theory should be superseded by the doctrine of the will to power. In so doing, I will be concerned to ascertain the extent to which Nietzsche considers Boscovich to be on the right path in overcoming materialistic atomism and how he thinks that Boscovich ultimately does not go far enough. My analysis will, then, be divided into two sections. The first will address what Nietzsche considers to be the success of Boscovich's 'force' physics in overcoming the primary/secondary quality distinction of metaphysical realism. The second section will take up the issue of Nietzsche's development of Boscovich's concept of force to formulate the doctrine of the will to power as an explanatory realist thesis. With this in mind I will now proceed to examine Boscovich and the overcoming of the primary/secondary quality distinction.

\subsection{Boscovich and the Overcoming of Primary and Secondary Qualities}

The metaphysical doctrine of the will to power makes the claim that "the concept of force is fundamental to scientific explanation and central within the scientific conceptual scheme". 77 The theory of force permeates both Nietzsche's analysis of the natural and the human sciences. He considers that his will to power metaphysics unites both the natural and the human sciences and thus that it adopts the most comprehensive perspective regarding the nature of things. He alludes to the doctrine of forces in BGE, 12 where he indicates that he accepts the general thrust of Boscovich's theory. In particular, Nietzsche credits Boscovich with having overcome 
the appearance/reality dualism of metaphysical realism by overturning the distinction between primary and secondary qualities. Thus in BGE, 12 and the passages that surround it Nietzsche makes it clear that he introduces Boscovichean physics in order to overcome what he terms "sensualism" in philosophy ${ }^{78}$ Sensualism, it seems, takes two forms and Nietzsche's disagreement with both centers round the issue of the primary/secondary quality distinction and the related issue of the foundationalist aspect of metaphysical realism. Closely related to these two issues, for Nietzsche, is the further issue of explanation. For it would seem to be his view that an overemphasis on either primary or secondary qualities renders void any attempt to proffer an explanation of the nature of things. The first form of "sensualism" is manifest, according to Nietzsche, in materialistic atomism. This is the Lockean view that the world in itself is to be understood as a quantitative realm of primary qualities.

This quantitative view deprives secondary qualities of any extra-mental existence. The quantitative view promotes 'the belief in 'substance', in 'matter', in the bit of earth, the particle, the atom". ${ }^{79}$ Nietzsche brands this model sensualism despite the fact that it distinguishes between the commonsense view which, for example, regards objects as intrinsically colourful, and the scientific view that considers colour to be the result of 'powers' in the object to produce the sensation of colour in observers. This is because this view, as construed by Nietzsche, attempts to "explain" our qualitative experience of the world by appealing to the quantitative view of atomistic physics. The quantitative perspective of atomistic physics is, incorrectly according to

\footnotetext{
${ }^{77}$ Lanier Anderson, "Nietzsche's Will to Power as a Doctrine of the Unity of Science", p. 749.

${ }^{78}$ In BGE, 15 Nietzsche employs the term "sensualism" in connection with subjective idealism. That he also intends this term to be equated with materialistic atomism can be seen from his claim in BGE, 12 that Boscovich and Copernicus taught us to reject materialistic atomism "contrary to all our senses".
} 
Nietzsche, taken as the standard of "objectivity". The realm of primary qualities is thus said to represent the way things are in themselves. Nietzsche states of this view that "The reduction of all qualities to quantities is nonsense". 80 Apart from its materialist claims, then, materialistic atomism, according to Nietzsche, puts forward one true description of the world. The difficulty here, for him, is that this one true description is adopted as an unrevisable thesis. It is founded on the view that metaphysics precedes epistemology. This is the belief that justification proceeds "from outside". That is, how things are, independently of our perspectival take on the world, is said to act as the ultimate court of appeal in the justification of our epistemic claims. Thus the materialistic atomist holds that justification and truth are determined extra-perspectivally. That this is Nietzsche's estimation of materialistic atomism can be discerned from his juxtaposition of the terms "inventing" and "finding". 81 In opposition to materialistic atomism, Nietzsche maintains that "inventing" precedes "finding". In so doing, he suggests that justification should proceed from "within" rather than from "without" and thus that it should be an intra-perspectival affair. Materialistic atomism is, then, in Nietzsche's estimation, a form of foundationalism that his perspectivist anti-metaphysical realism seeks to reject. Consequently, in BGE, 20 he rejects Locke's account of the origin of our ideas as a superficial account.

The second form of sensualism that Nietzsche rejects is empirical idealism. Nietzsche rejects this model because it reduces the world to the mental. Reality, according to this view, is reducible to, and constituted by, our representations. This

\footnotetext{
${ }^{79}$ Ibid., 12.

${ }^{80}$ Nietzsche, WP, 564 (1885-1886).

${ }^{81}$ Nietzsche, BGE, 12.
} 
involves reducing the body to the mental. Nietzsche articulates his disagreement with

this view in the following passage:

In order to practise physiology with a good conscience, you have to believe that the sense organs are not phenomena in the philosophical idealist sense, for then they could not be causes! This is sensualism as a regulative hypothesis at least, if not as an heuristic principle.

What's that? And other people are actually saying that the external world is created by our sense organs? But then our body, as part of this external world, would be the creation of our sense organs! But then our very sense organs would be - the creation of our sense organs! It seems to me that this is a complete reductio ad absurdum: assuming that the concept causa sui is something completely absurd. It follows that the outer world is not the creation of our sense organs - ? $^{\text {2 }}$

The view rejected as incoherent in this passage bears an uncanny resemblance to Berkeley's articulation of his idealist position through the voice of Philonous, who in response to Hylas' suggestion that the perception of ideas can be explained in terms of 'various impressions or traces--made in the brain' claims:

The brain --- you speak of, being a sensible thing, exists only in the mind. Now, I would like to know whether you think it reasonable to suppose, that one idea or thing existing in the mind, occasions all other ideas. And if you think so, then how do you account for the origin of that primary idea or brain itself. ${ }^{83}$

According to Berkeley, our physiological apparatus consists of ideas and so cannot play an ultimate role in the production of ideas. Here Berkeley rejects the causal theory proffered by Locke that enabled Locke to accept the findings of science and claim that our representations are of mind-independent objects. Berkeley who, in contrast to Locke, founds his idealism on the relativity of perception claims that the "immediate objects of perception are mind-dependent data". ${ }^{84}$ In so doing, Berkeleian idealism adopts a form of reductionism by reducing the world to ideas or representations. The difficulty here, according to Nietzsche, is that empirical idealism emphasizes a subjective standard as the measure of what is objectively real. Thus in a

\footnotetext{
${ }^{82}$ Ibid., 15.

${ }^{83}$ George Berkeley, Three Dialogues between Hylas and Philonous in Principles of Human Knowledge/Three Dialogues, (London: Penguin, 1988), Second dialogue p. 158.

${ }^{84}$ I.C. Tipton, Berkeley: The Philosophy of Immaterialism, (London: Methuen and Co., 1976), p. 253.
} 
similar manner to Hilary Putnam, Nietzsche brands both materialism and empirical idealism instances of metaphysical realism. Both operate within the confines of the primary/secondary quality distinction and thus within the appearance/reality dichotomy. Both materialism and empirical idealism operate within the metaphysical realist appearance/reality distinction by adopting what Putnam terms,

[---] the assumption that there is a clear distinction to be drawn between the properties things have 'in themselves' and the properties which are 'projected by us'.

The empirical idealist maintains that there are only minds and sense-data and that "red", for example, is an intrinsic property whilst "persistence" is a mere "projection". This claim does not strictly apply to Berkeley if we construe Berkeley's task as that of dismantling the distinction between primary and secondary properties to the extent that he reduces the former to the latter. However, the claim that empirical idealism is guilty of an appearance/reality distinction whereby persistence is deemed to be a projection may arguably be attributed to Hume's bundle theory of objects. That Nietzsche may have had this in mind is suggested by The Will to Power, 101 where Nietzsche claims that Kant makes "the epistemological skepticism of the English possible for Germans", and by his reference to both Hume and Locke in this passage. According to the bundle theory, objects are reducible to collections of ideas or mental representations. The idea of a persisting object is, according to this view, a projection of the mind. However, the materialist maintains, in contrast to the subjective idealist, that external objects have persistence as an intrinsic property, and that "red" is something that we project. ${ }^{86}$ By emphasizing one or other of the polarities in these related distinctions, both forms of sensualism (that is, empirical

${ }^{85}$ Putnam, MFR, p. 13. 
idealism and materialism) promote opposing forms of foundationalism and, in so doing, both make the claim that there is one correct unrevisable description of the world or one ultimate science. In so doing, both materialism and subjective idealism, in Nietzsche's view, are one-sided arguments that give priority to either natural science (the quantitative "objective" view) or to human science (the qualitative "subjective" view). Both views, according to Nietzsche, are guilty of taking what is a "partial perspective" and treating it as an extra-perspectival standard of justification. In so doing, both operate within the framework that prioritizes metaphysics over epistemology. They do this by conflating their limited perspective regarding the ultimate nature of things with how things are in themselves, whether the thing-initself is mental as in empirical idealism or extra-mental as in materialism. In effect, then, Nietzsche maintains that both subjective idealism and materialistic atomism consider themselves to be making extra-perspectival appeals to knowledge. We have seen, in part one of this chapter, that Nietzsche's doctrine of the will to power avoids this fate because it attempts to "unify" the various sciences rather than reduce all explanation to any one of them. Rather than adopt a limited perspective and conflate it with an extra-perspectival standard, Nietzsche attempts to adopt a more comprehensive perspectival approach. This involves, as we saw in part one, consideration of the perspectives of both the human and the natural sciences. The will to power is properly speaking intra-contextual rather than reductionist. It is in this context that Nietzsche's doctrine of the will to power is designed to find a middle

${ }^{86}$ Ibid., p. 9 
ground between the polarities of materialism and idealism. ${ }^{87}$ For an overemphasis on either primary or secondary qualities renders impotent, in Nietzsche's view, the power of both materialism and idealism to "explain" the nature of the phenomenal world that we are "familiar with" ${ }^{88}$ This can be seen initially in Nietzsche's rejection of the materialist's appeal to "intrinsic properties". Locke distinguished between primary, secondary and tertiary qualities. Primary qualities are said to be "intrinsic" properties of a thing to the extent that they are non-relational, non-dispositional and non-subjective. Primary qualities, then, according to this view, constitute the way things are in themselves. Both secondary and tertiary qualities, however, are powers in the object to produce certain types of effect. To the extent that they are understood as powers, secondary and tertiary qualities are both relational and dispositional properties. Thus, at the level of metaphysics, there is little difference between secondary and tertiary qualities. They differ, however, at the level of epistemology. For secondary qualities produce effects on human perceivers. They are thus subjective and perceiver-dependent. Tertiary qualities, in contrast, are said to be objective because they produce effects on things other than human sensibility. For example, both "yellow" and "soluble" are relational properties. However, "yellow" implies a certain relation to a human perceiver whilst "soluble" implies a certain relation to aqua regia. ${ }^{89}$ By adopting the view that relations are irreducible to intrinsic properties, Locke claims that relational properties or powers are less fundamental than primary qualities. Primary Qualities are said to give us "an Idea of the thing, as

\footnotetext{
${ }^{87}$ John Richardson also reads the will to power as forging a midway between materialism and idealism. See Nietzsche's System, p. 38.

${ }^{88}$ Nietzsche, HAH, 16.
} 
it is in itself ${ }^{90}$ However, because relational properties are irreducible to intrinsic properties, in Locke's view, ${ }^{91}$ relational properties (whether they be secondary or tertiary in character), cannot provide us with any insight into the ultimate nature of things. ${ }^{92}$ Our qualitative experience of the world we are "familiar with" cannot explain the intrinsic nature of things. The possible rejoinder that claims that primary qualities explain the existence of secondary qualities is of little consequence for Nietzsche because the appeal to primary qualities represents, in his view, an attempt to establish an extra-perspectival standard of explanation. Nietzsche, therefore, holds the view that the materialist appeal to intrinsic properties results in a dissociation of the way things are in themselves from the qualitative world that we are familiar with.

The explanatory impotence of the primary/secondary quality distinction can be witnessed, secondly, in Berkeley's idealist treatment of the issue. Berkeley, in contrast to Locke, reduces primary qualities to secondary qualities. It might be wondered then why Nietzsche quarrels with Berkeley with regard to this issue. For surely, it might be asked, Berkeley removes the Lockean idea of a realm of intrinsic non-relational properties that constitute how things are in themselves. It might be argued, then, that Berkeley saves the world that we are "familiar with". We have seen

\footnotetext{
${ }^{89}$ See Rae Langton, Kantian Humility: Our Ignorance of Things in Themselves, (Oxford: Clarendon Press, 1998), p. 152 for this issue.

${ }^{90}$ Locke cited by Langton, Kantian Humility, p. 148.

${ }^{91}$ Ibid., pp. 154-5.

${ }^{92}$ Langton captures this aspect of Locke's thinking when she explains the status of relational properties in Locke's system:

Locke believes that powers do not supervene on the primary qualities of a thing, but rather have their source in a superadding creative act of God. To ascribe to Locke the doctrine of superadded forces is to ascribe to him the view that God could have made the world exactly as it is with respect to the primary qualities of things, and yet have endowed those things with powers different from the powers they actually have - or perhaps to have endowed them with no powers at all. Translating the same modal point into contemporary terminology, there are possible worlds where things have the same intrinsic properties they actually have, yet possess different powers - or no powers at all. (Ibid., pp. 154-5).
} 
the manner in which Nietzsche rejects Berkeley's idealism for its lack of a realist constraint. However, in this specific context, Nietzsche would seem to adopt the view that Berkeley's position is untenable because Berkeley's mental thing-in-itself is devoid of explanatory power and so does not, despite Berkeley's claim to the contrary, "save the phenomena". This is because Berkeley arguably appeals to the very phenomena that require explanation as an explanation. ${ }^{93}$ Thus Nietzsche would seem to adopt the view that, in the absence of any valid appeal to God as an ultimate explanation, Berkeley can only give "descriptions" rather than "explanations" of how things are. This is perhaps partly what Nietzsche means when he praises Boscovich for having overcome sensualism in philosophy. For it is Nietzsche's view that we cannot rely on the senses alone to provide an explanation of our qualitative experience of the world. Rather, he suggests that we must speculate and probe beyond the immediate evidence of the senses. ${ }^{94}$ This is arguably what Nietzsche has in mind when he champions the "triumph over the senses". 95 From the above we can see that it is Nietzsche's aim to overcome both materialism and subjective idealism. For by emphasizing either primary or secondary qualities both views, he contends, run into

\footnotetext{
${ }^{93}$ Nietzsche makes a similar point with regard to Kant's appeal to a "faculty" to explain the possibility of synthetic a priori judgements:

The time came for them to rub their foreheads: they are rubbing them still today. They had been dreaming, and the first among them had been old Kant. 'Facilitated by a faculty' - that's what he had said, or at least that's what he had meant. But what kind of an answer is that? Isn't it rather simply repeating the question? How can opium make us sleep? Is it 'facilitated by a faculty', the virtus dormitiva, answers the doctor in Molière, [---] (BGE, 11).

${ }^{94}$ Susan Neiman makes a similar point to Nietzsche when she argues that

The capacity to demand explanations of experience requires the capacity to go beyond experience, for we cannot investigate the given until we refuse to take it as given. To ask a question about some aspect of experience, we must be able to think the thought that it could have been otherwise. Without this thought, we cannot even formulate the vaguest why. [Susan Neiman, The Unity of Reason: Rereading Kant, (Oxford: Oxford University Press, 1994), p. 59].
} 
difficulties when it comes to explaining the nature of phenomena. Locke's distinction between intrinsic and relational properties results in a dissociation of how the world is in itself from its relational character. Berkeley's emphasis on secondary qualities deprives him of the ability to provide an explanation of the phenomenal relational world. Nietzsche argues that the overcoming of these two poles is best achieved through recourse to Boscovichean physics which, in his view, succeeds in partially paving the way for a more suitable explanation of the furniture of the world than that proffered by either materialistic atomism or subjective idealism. It is on this note that I turn to Boscovich's force theory.

In BGE, 12 Nietzsche introduces Boscovich's theory of forces as a rejection of materialistic atomism:

As regards materialistic atomism, hardly anything has ever been so well refuted; in all Europe there is probably no scholar so unschooled as to want to credit it with serious meaning, apart from a handy everyday usefulness (that is, as a stylistic abbreviation). This we owe primarily to the Pole Boscovich, who along with the Pole Copernicus achieved the greatest victory yet in opposing the appearance of things. For while Copernicus convinced us to believe contrary to all our senses that the earth does not stand still, Boscovich taught us to renounce the last thing that 'still stood' about the earth, the belief in 'substance,' in 'matter,' in the bit of earth, the particle, the atom: no one on earth has ever won greater triumph over the senses.

Boscovich rejects materialistic atomism by arguing that matter is to be explained in terms of fields of force. Rom Harré and E. H. Madden explain that field physics is designed to overcome the distinction between primary and secondary qualities. It does this to the extent that it aims to replace both the notions of a quality-less substratum (Lockean materialism) ${ }^{96}$ and substance-less qualities (sensible

\footnotetext{
${ }^{95}$ Nietzsche, BGE, 12. It is to be noted that this is not incompatible with Nietzsche's empiricism and demand for a realist constraint. For such speculations beyond the senses are ultimately bound to provide an "explanation" of the empirical world that we are familiar with.

96 Strictly speaking, Locke's account of "real essence" is not quality-less if we consider that real essence is constituted by a thing's intrinsic or primary qualities. However, for purposes of the contrast being drawn here, Lock's real essence can be said to be quality-less to the extent that it is devoid of
} 
realism/Berkeleian idealism) with a dynamic conception of matter. Harré and Madden

state:

The dynamist opposes his theory of material substance to both materialist theories and phenomenalist theories [--] Materialist theories are rejected on the grounds that, in the end, they require the postulation of some sort of quality-less substance, and phenomenalist theories on the grounds that they end up in free-floating or substance-less qualities. Both derive their metaphysics from generalisations of the same feature of ordinary experience, the obvious distinction in experience between a material substance and the various qualities which it can take on successively or together. A dynamist can see no reason why the ultimates of our world should be modelled on this particular feature of our experience when everything points to a different conception of the nature of things. ${ }^{97}$

Although Nietzsche's consideration of Boscovich in BGE, 12 focuses on his rejection of materialistic atomism, we have seen from an examination of the surrounding passages that Nietzsche also has the rejection of empirical idealism in mind. Moreover, Nietzsche thinks that Boscovich's force theory overcomes the reliance on the primary/secondary quality polarity that forms the bedrock of both materialism and subjective idealism. However, since in BGE, 12 Nietzsche credits Boscovich with having overcome materialistic atomism in particular, I will focus my attention on Boscovich's relation to this mode of thought.

As an attempt to overcome materialistic atomism, then, the dynamic theory of matter is, in Nietzsche's view, an instance of conceptual change. According to the mechanical atomism of the Corpuscularian theory, every physical interaction must be analyzable into transfers of motion between interacting corpuscles. Atoms, according to this view, are irreducible and, as such, they are said to characterize what is most fundamental. A problem arises, however, when we ask what happens when these

any relational (tertiary or secondary) qualities. Real essence is quality-less, then, in so far as it is a quantitative, scientific conception rather than a qualitative one.

${ }^{9}$ Rom Harré and E. H. Madden, Causal Powers: A Theory of Natural Necessity, (Oxford: Basil Blackwell, 1975), pp. 166-7. 
problematic in the following way:

Being atomic they must be rigid, since the theory requires that compressibility is always explained as the possibility of the occupation of a smaller volume by a set of rigid corpuscles originally spread through a certain larger volume. But in the interaction by contact of truly rigid bodies their centres of gravity must instantaneously acquire new velocities by a finite increment, thus changing their speed discontinuously. ${ }^{98}$

Such an instantaneous change of velocity violates the law of continuity "which denies

the passage from one magnitude to another without passing through intermediate stages". ${ }^{99}$ In response to this difficulty Boscovich, in contrast to Maclaurin who argued that force should be expunged from physics, maintained that matter rather than force should be eliminated. ${ }^{100}$

The trouble, Boscovich saw, derived from the generalisation of the theory of primary and secondary qualities upon which the attempt to found physics in mechanics was based. His solution was to give an account of whatever is fundamental to body in terms of a system of forces centred upon points. ${ }^{101}$

By introducing the notion of a repulsive force that acts at small distances between

bodies and which transforms into an attractive force at greater distances, Boscovich

argues that there is a continuous change in velocity according to the distance between

two bodies. Max Jammer articulates this point in the following way:

Since real contact never actually takes place, claims Boscovich, the force of repulsion increases indefinitely as the distance decreases. At greater distances the repulsive force changes its sign, so to say, and becomes attractive, thus accounting for the common phenomena of gravity and gravitation. On the basis of Boscovich's theory of forces, it is the same to assert that contact never takes place or to say that it always takes place, since two bodies have always a dynamic connection that depends on their relative distance alone. Each and every particle of the universe is dynamically related to every other particle, the magnitude and direction of the force involved being a function of the distance concerned. Boscovich's theory thus reduces contact phenomena to actions at a distance and consequently eliminates impact as a fundamental concept of mechanics. ${ }^{102}$

\footnotetext{
${ }_{98}$ Ibid., p. 169.

99 Max Jammer, Concepts of Force: $A$ Study in the Foundation of Dymamics, (Cambridge: Harvard University Press, 1957), p. 172.

${ }^{100}$ Harré and Madden, Causal Powers: A Theory of Natural Necessity. p. 169.

${ }^{101}$ Ibid.

102 Jammer, Concepts of Force, pp. 173-4.
} 
Of particular interest to us here is the fact that Boscovich takes unextended physical points to be the ultimate constituents of matter thus rejecting both the materialist emphasis on primary qualities and the subjective idealist reliance on secondary qualities. In their stead Boscovich draws our attention to tertiary qualities, which, we have seen, are relational, dispositional and objective properties. Tertiary properties allow for relations between things in the world without construing such relations as mind-dependent. ${ }^{103}$ In so doing, Boscovich overcomes both the Lockean emphasis on intrinsic properties as the standard of objectivity, and the idealist reduction of the objective to the subjective relational secondary properties. Poellner articulates the manner in which Boscovich's theory of forces overcomes the primary/secondary quality opposition as follows:

In Locke's terminology matter, in itself, has no primary qualities which distinguish it from empty space and which are the basis of a material objects tertiary qualities, its 'powers' to make a 'change in the bulk, figure, texture and motion of another body. The forces - such as gravitational force - which appear to 'emanate' from material objects distinguishable from them on account of the latter's primary qualities are, in fact, not ontologically dependent on any such qualities distinct from them; rather, material objects consist exclusively of such forces. ${ }^{104}$

By emphasizing tertiary qualities, Boscovich's force physics can be seen to initiate the rejection of intrinsic properties that Nietzsche desires. We have seen that Nietzsche rejects intrinsic non-relational properties because they, as we saw in the case of Locke, dissociate the world we are familiar with from the way the world is in

${ }^{103}$ This is what Nietzsche has in mind when he states of the will to power:

I do not mean the material world as a delusion, as 'appearance' or 'representation' (in the Berkeleian or Schopenhauerian sense), but rather [---] as a kind of instinctual life in which all the organic functions [---] are synthetically linked to one another [---]. (Nietzsche, BGE, 36).

${ }^{104}$ Peter Poellner, Nietzsche and Metaphysics, (Oxford: Clarendon Press, 1995), p. 50. 
itself. $^{105}$ Boscovich's theory of forces thus forms part of the essential background from which Nietzsche's dynamist theory emerges and against which it must be understood. However, Boscovich and Nietzsche part company on the issue of explanation. For it would seem to be Nietzsche's view that, although Boscovich makes considerable progress in providing the path to overcoming the explanatory impotence of both idealism and materialism, he has not gone far enough. Here we reach the first aspect of the double accountability clause mentioned earlier. In seeking to explain the reasons why his own will to power thesis is a development and alteration of Boscovich's theory and thus an instance of conceptual change, Nietzsche must demonstrate that his own thesis is more accurate than that of Boscovich. It is to this issue that I now direct my attention.

\subsection{The Will to Power as an Explanatory Realist Thesis}

Nietzsche suggests that Boscovich has succeeded in overcoming materialistic atomism to the extent that he overcomes the polarity of the primary/secondary quality

${ }^{105}$ Rae Langton argues that Kant's "epistemic humility" results in his acceptance of a somewhat similar view to Locke. According to Langton, Kant's view regarding the irreducibility of relations results in him making a distinction between the "pure concept of substance" and the concept of substance "as an appearance". (Langton, Kantian Humility, p. 136). The pure concept of substance refers to the realm of intrinsic non-relational things-in-themselves. Substance as an appearance refers to relational tertiary properties called forces. Nietzsche's view differs from that of both Locke and Kant to the extent that he rejects the idea of intrinsic properties. This aspect of Nietzsche's philosophy is difficult and the scope of our present discussion cannot possibly do it justice. However, some readings argue that Nietzsche's rejection of intrinsic properties entails the view that there cannot be subject-independent objects. Such readings consider Nietzsche's perspectivism to entail the view that subject-independent properties are inconceivable. (See, for example, Poellner's Nietzsche and Metaphysics, esp. pp. 55-6, 109-11, 249-50, 284-8.) However, by regarding Nietzsche's rejection of intrinsic properties in terms of Boscovich and the emphasis on tertiary qualities we can see that Nietzsche arguably allows for objective relational properties rather than just subjective ones. 

explanation:

${ }^{106}$ It is in this sense that Boscovich represents, for Nietzsche, "the greatest victory yet in opposing the appearance of things" (Nietzsche, BGE, 12.) Nietzsche also articulates this view of Boscovich's achievements in a letter to Peter Gast, March 20, 1882:

Boscovich and Copernicus are the two greatest opponents of optical observation. With effect from him there is no 'matter' (Stoff) any more - except as a source of popular belief. He has thought the atomistic doctrine through to the end. (Cited by Keith Ansell-Pearson, "Nietzsche's Brave New World of Force" in Pli: The Warwick Journal of Philasophy, Volume 9, 2000, p. 27).

${ }^{107}$ Boscovich considers his attractive and repulsive forces to be both philosophically unproblematic and a satisfactory explanation of phenomena. He maintains that although we are ignorant of the causes of forces there is nothing obscure or mysterious about them:

[---] everybody knows what approach means, and what recession is; everybody knows what it means to be indifferent, \& what having a propensity means; $\&$ thus the idea of a propensity to approach, or to recede, is perfectly distinctly attained. (Boscovich cited by Poellner, Nietzsche and Melaphysics, p. 51).

However, Nietzsche charges that Boscovich's forces are "occult qualities" that render the familiar unfamiliar. He claims that

The development of science resolves the 'familiar' more and more into the unfamiliar: - it desires, however, the reverse, and proceeds from the instinct to trace the unfamiliar back to the familiar. (Nietzsche, WP, 608, 1886-1887).

Nietzsche thinks that his own theory of the will to power saves the world we are familiar with rather than reducing it to unfamiliar occult qualities. However, some commentators argue that, despite these protestations, Nietzsche is also guilty of appealing to occult qualities. For example, James I. Porter argues that Nietzsche's metaphysical picture of competing centers of force is alienating. [James 1 . Porter, The Imvention of Diomysus, (Stanford: Stanford University Press, 2000), p. 27]. In the remainder of this chapter, we will see how Nietzsche denies this charge. He claims that his will to power thesis is founded, in part, on our acquaintance with the actual "compulsion" of forces, through our acquaintance with our own experience of willing. Moreover, it can arguabl be claimed that by putting forward an "explanation" of the phenomenal world, the will to power, in:80 far as it is successful in achieving this aim, leaves the world with which we are familiar intact. However, as a detailed engagement with this complex issue would steer me away from my present course, I will refrain from engaging in this debate in detail.

${ }^{108}$ Nietzsche argues that physics generally has, incorrectly in his view, considered itself as providing "explanations" of phenomena rather than just one description among many other possible contenders. He states that "It now may be dawning on five or six thinkers that even physics is only a way of interpreting or arranging the world (if I may say so: according to us!) and not a way of explaining the world". (Nietzsche, BGE, 14). 
One cannot "explain" pressure and stress themselves, one cannot get free of the actio in distans: - one has lost the belief in being able to explain at all, and admits with a wry expression that description and not explanation is all that is possible, that the dynamic interpretation of the world, with its denial of "empty space" and its little clumps of atoms, will shortly come to dominate physicists; though an inner quality in dynamis- ${ }^{109}$

Nietzsche maintains that the Boscovichean concept of force needs to be supplemented with an "inner will" if it is to achieve an explanatory rather than a mere descriptive status:

The victorious concept "force", by means of which our physicists have created God and the world, still needs to be completed: an inner will must be ascribed to it, which I designate as "will to power", i.e., as an insatiable desire to manifest power; or as the employment and exercise of power, as a creative drive. ${ }^{110}$

By arguing that his concept of force requires further development Nietzsche suggests that Boscovich has only partially overcome materialistic atomism. In this way we must see Nietzsche's attempt to provide Boscovich's theory with a supplementary explanatory element as a response to a deficit in materialistic atomism. It is in this context, then, that I suggest that Nietzsche's ascription of an inner will to force can be seen as an attempt to overcome, what he considers to be, the explanatory paucity of the materialistic atomist understanding of causality. The materialistic atomist understands causality according to the classic billiard ball analogy. That is, causality is understood "as a rigid, one-directional system of colliding atoms." 111 Nietzsche levels the same charge at materialistic atomism's treatment of causality as he does at

\footnotetext{
${ }^{109}$ Nietzsche, WP, 618 (1885). Peter Poellner points out that although Nietzsche follows Schopenhauer and Lange in holding the view that forces are devoid of explanatory power, the argument originated with Newton. Poellner cites Newton who in a letter to Bentley articulates his view that action at a distance is devoid of explanation:

That gravity should be innate, inherent, and essential to matter, so that one body may act upon another at a distance through a vacuum, without the mediation of anything else, by and through which that action and force may be conveyed from one to another, is to me so great an absurdity, that I believe no man, who has in philosophical matters a competent faculty of thinking, can ever fall into it. (Newton cited by Poellner, Nietzsche and Metaphysics, pp. 523).

${ }^{110}$ Nietzsche, WP, 619 (1885).

"II Cox, Nietzsche: Naturalism and Interpretation, p. 221.
} 
Boscovich's theory of forces. He maintains that both views are descriptions rather than explanations of phenomena (though he thinks that Boscovich puts forward a more apt description). Nietzsche thus maintains that materialistic atomism merely describes immanent motions without getting inside them to explain them. ${ }^{112}$ Unable to get inside them, materialistic atomism appeals to a transcendent principle in the form of God as the ultimate explanation of cause and effect. ${ }^{113}$ Christoph Cox captures the materialistic atomist view when he states:

It does not tell us what motivates one entity to affect another - except that this motion is itself the effect of a prior "cause" and so on, producing a regress that terminates with the only genuinely active force: God the Watchmaker who sets the world-mechanism in motion. ${ }^{114}$

The role of God, according to Nietzsche's interpretation of materialistic atomism, represents a transcendent rule imposed from without to ensure the regularity of nature. In so doing, Nietzsche maintains that materialistic atomism puts forward a metaphysical realist God's Eye View as the standard of explanation. Cox articulates this aspect of materialistic atomism in the following way:

The mechanistic view [---] sees the world as essentially static - a system closed, reversible, and in equilibrium. It posits a universe in which, from any given state, all other states, past and future, could, theoretically, be calculated. [---] It is this theoretical vantage point, this God's-eye view of an eternal present, to which the mechanistic physicist aspires. ${ }^{115}$

By adopting the God's Eye View as the standard of explanation, materialistic atomism, as interpreted by Nietzsche, maintains that the regularity of nature can ultimately be understood in terms of obedience to God's rule. Nietzsche rejects the materialistic atomist argument, however, because it appeals to an extra-perspectival

112 Cox describes Nietzsche's rejection of materialistic atomism in these terms. (Ibid., p. 219). Cf., BGE, 14, WP, 618 (1885), 628 (1885-6), 629 (1883-1888), 630 (1885), 631 (1885-6), 632 (1885-6), 660 (1885-6), 688 (1888).

113 This charge arguably applies to Berkeley's appeal to God as the ultimate explanation or cause of our ideas. However, in keeping with my strategy so far, I will focus my attention on Nietzsche's response to materialism.

${ }^{114}$ Cox, Nietzsche: Naturalism and Interpretation, p. 219. 
chapter, that our epistemic claims should be subject to a realist constraint. It does this, according to Nietzsche, by putting forward an extra-empirical ideal of knowledge. Furthermore, the appeal to God represents, in his view, a superfluous teleology ${ }^{116}$ that violates his maxim regarding the economy of principles. ${ }^{117}$ Nietzsche's ascription of an "inner will" to force can be understood in the context of his desire to overcome such extra-empirical and superfluous teleological explanations. ${ }^{118}$ He thus replaces, what he considers to be, the materialistic atomist appeal to a divinely rule-governed world with the will to power. The will to power thesis puts forward the view that we more correctly construe what materialistic atomism takes to be "obedience"119 to

115 lbid.

116 Nietzsche, BGE, 13. Cf. WP, 1062 (1885), 1066 (1888).

117 Interestingly, Kant makes a similar point to Nietzsche when he argues that to employ God as a constitutive principle makes the internal unity of nature accidental:

The regulative principle prescribes that systematic unity as a unity in nature, which is not known merely empirically but is presupposed a priori (although in an indeterminate manner), be presupposed absolutely, and consequently as following from the essence of things. If, however, I begin with a supreme purposive being as the ground of all things, the unity of nature is really surrendered, as being quite foreign and accidental to the nature of things, and as not capable of being known from its own universal laws. (Kant, CPR, A693/B721).

118 Kant is faced with a similar difficulty in his Critical period in his aspiration to reconcile mechanism and teleology without overstepping his own boundary of the possibility of experience. Kant adopts Maupertuis' maxim of explanatory economy in his search for systematic unity. [see Gerd Buchdahl, Metaphysics and the Philasophy of Science: The Classical Origins from Descartes to Kant, (Oxford: Basil Blackwell, 1969), p. 491-2]. However, whereas Maupertuis appeals to the metaphysical idea of God as a unifying principle, Kant, in an attempt to avoid the twin dangers of dogmatism and empiricism (appeal to Humean isolated phenomena), appeals to a heuristic and regulative idea of God as a unifying explanatory principle. Thus the appeal to God is de-ontologized in Kant and becomes a regulative idea of Reason that prescribes us to treat "unity as a methodological recommendation". (Buchdahl p. 506). Thus, for Kant, we can appeal to the empirical lawlikeness and systematic unity of nature as a regulative idea of Reason. Furthermore, such regulative ideas facilitate the movement beyond the merely observable and allow us to talk of systematic interconnection.

Although Kant appeals to the principle of explanatory economy, his particular application of this principle remains unsatisfactory according to Nietzsche. For we saw in chapter one that Nietzsche thinks that Kant has ulterior moral motives in introducing God as a regulative principle. Moreover, we witnessed Nietzsche's view that Kant's constitutive account of knowledge weakens his regulative conception of belief by denying it any cognitive status.

${ }^{119}$ Nietzsche, WP, 629 (1883-1888). 
that the rules governing the operations of nature are intrinsic rather than extrinsic to nature itself. Nietzsche states:

\begin{abstract}
"Regularity" in succession is only a metaphorical expression, as if a rule were being followed here; not a fact. In the same way, "conformity with a law." [-- That something always happens thus and thus is here interpreted as if a creature always acted thus and thus as a result of obedience to a law or a lawgiver, while it would be free to act otherwise were it not for the "law." But precisely this thus-and-not-otherwise might be inherent in the creature, which might behave thus and thus, not in response to a law, but because it is constituted thus and Itrus. All it would mean is: something cannot also be something else, cannot do now this and now something else, is neither free nor unfree but simply thus and thus. [my italics] ${ }^{121}$
\end{abstract}

On the basis of the above it may arguably be claimed that Nietzsche thinks that Boscovich's rejection of materialistic atomism fails to find some alternative to the materialist's appeal to God as the motivating factor governing the operations of nature. The materialist's account is unsatisfactory, in Nietzsche's view, because it

${ }^{120}$ Ibid., 631 (1885-1886), Cf. WP, 633 (1888).

121 lbid., 632 (1885-1886). However, Alistair Moles remarks that Nietzsche's argument here is a weak one. Moles maintains that it is not clear that any account of natural law proposed in recent centuries has been prescriptive in the sense suggested by Nietzsche. Moles states:

The weakness of Nietzsche's critique of the notion of the lawfulness of events is that he considers natural laws only as prescriptive. In other words, his primary model of natural law is the regulation of human societies, where restrictions are placed on the behavior of individuals within the social group. His secondary model is the behavior of an artifact constructed to achieve some purpose extrinsic to itself. In both cases, events could happen differently: in the former, because humans presumably behave differently when subject to the constraint of law than when they are not; in the latter, because machines are built to act differently depending on the different purposes selected for them. But it is in fact very doubtful whether any natural law proposed in recent centuries has been conceived as prescriptive, in the way Nietzsche presents it. Instead, a law is a generalized description of natural events, as they actually happen, and is not regarded as a nule to which these events are obedient -- despite the deceptive phrase "obedience to law" - in the sense of being free to disobey. Such laws are intellectual structures, by which an attempt is made to explain the regularities that are perceived to exist within events. [Alistair Moles, Nietzsche's Philosophy of Nature and ('asmology, (New York: Peter Lang, 1990), pp. 206-207].

It would seem that if this is a weakness in Nietzsche's argument here, then, it must count against the plausibility of the will to power metaphysics. However, I will not address this issue here as my main concern is with the methodological and epistemic commitments of the doctrine. The reason for this is that it is clear that Nietzsche did not consider the doctrine an unrevisable one. However, he seems to endorse the methodology of the doctrine in an unqualified sense so that any changes or alterations that may be made to the doctrine must be made from within this methodological framework. Thus I am examining the metaphysics of the will to power here only to draw out the methodology that Nietzsche employs. 
posits this motivating factor outside nature. Nietzsche thinks that Boscovich fails to overcome the materialistic atomist appeal to God because Boscovich, in his view, fails to replace the role that God plays in materialistic atomism with an alternative explanation. Thus by arguing that Boscovich's force physics is a description rather than an explanation, Nietzsche claims that Boscovich's account of attractive and repulsive force fails to capture the "motivation" governing this dynamic relationship. Real comprehension involves, for Nietzsche, an acquaintance with the "compulsion"122 or the actual causal powers involved in an event or activity. ${ }^{123}$ Boscovich's dynamic theory, according to Nietzsche, does not adequately capture this compulsion that Nietzsche himself calls the will to power. At this point we must recall that, for Nietzsche, an objective account of the nature of things must unify both the human and the natural sciences. If Nietzsche can show that the ascription of an "inner will" to force has explanatory power in the human sciences as well as in the natural sciences, then he will, according to his own criteria, have established the "objectivity" of the will to power thesis. It is with this in mind that Nietzsche claims that we are acquainted with the actual compulsion or "inner will" of force through our own experience of willing. He mediates his discussion of the phenomenon of willing with a re-appraisal of the atomistic conception of the self. He develops a nonatomistic conception of the self by arguing that the self is an organization of competing drives motivated by the desire for power. Thus the general task set in BGE, 12 is to extend the rejection of atomism in physics to the atomistic conception of the soul:

${ }^{122}$ Nietzsche, WP, 664 (1883-1888). 
However, we must go even further and declare war, a merciless war unto the death against the 'atomistic need' that continues to live a dangerous afterlife in places where no one suspects it (as does the more famous 'metaphysical need'). The first step must be to kill off that other and more ominous atomism that Christianity taught best and longest, the atomism of the .$x$ wol! ${ }^{1.2}$

Moreover, Nietzsche's particular task is to show that the will to power has explanatory force in the human sciences. If he is to achieve this he must show that the will to power has greater explanatory power than previous psychological explanations of human behaviour. In so doing, Nietzsche suggests that his revised conception of the self best explains the paradoxical phenomena whereby we feel that our wills are free despite the incompatibility of such a view with the scientific deterministic worldview. ${ }^{125}$ He does this by conceiving the self as a social structure of drives, each of which have their own agenda that they wish to pursue and implement. The success of the drives in achieving their own specific agenda depends on its relations with the other drives that compose the self. In order to attain their individual goals, each drive must enter into negotiations and agreements with the other drives. In BGE, 19 Nietzsche extends this conception of the self to our experience of willing in order to explain how it is that we experience our wills as free. Willing, according to Nietzsche, is a complex process involving sensation, thought and affect. The experience of willing involves, in his view, both the affect of commanding and the affect of obeying. Willing, he claims, involves a hierarchical organization of drives:

A person who wills: this person is commanding a Something in himself that obeys, or that he thinks is obeying.

But let us now consider the strangest thing about the will, about this multifarious thing that the common people call by one word alone. In any given case we both command

123 See Peter Poellner, "Perspectival Truth" in John Richardson and Brian Leiter (eds.), Nietzsche. (Oxford: Oxford University Press, 2001), p. 93.

124 Nietzsche, BGE, 12.

${ }^{123}$ See Lanier Anderson, "Nietzsche's Will to Power as a Doctrine of the Unity of Science", p. 743 
and obey. and when we obey we know the feelings of coercion, pressure, oppression, resistance, and agitation that begin immediately after the act of will. ${ }^{126}$

According to Nietzsche the feeling of free will ensues from the conflation of the affect of commanding with the affect of obeying. The identification of both feelings leads us to "attribute the competence which actually carries out the task to the same will that has the power to order it done." ${ }^{127}$ Nietzsche states:

'Freedom of the will' - that is the word for that complex pleasurable condition experienced by the person willing, who commands and simultaneously identifies himself with the one who executes the command - as such he can share in enjoying the triumph over resistance, while secretly judging that it was actually his will that overcame that resistance. ${ }^{128}$

In keeping with his thesis regarding the unity of science, Nietzsche intends that this psychological model bear a significant resemblance to his will to power physics. The structural similarity resides in Nietzsche's hypothesis ${ }^{129}$ that both the world and the self can best be explained as a power struggle between power seeking forces and drives. Lanier Anderson articulates the similarity in the following way:

Just as the nature of each particle is to exert force on its environment, so the nature of each drive is to exert its force on the others which make up the self to which it belongs. Because physical particles are nothing but force, their exertion is indiscriminate. Their 'will' is not some special end, but the expenditure of force itself. It is a will to power. Similarly, in the internal politics of the self, drives are characterized by the indiscriminate exercise of force against the others. i.e. by will to power. The structural similarity of these explanations provides force to the argument which infers from the unity of science under the concept of will to power to a methodological bias in favour of the non-atomistic interpretation of the self. ${ }^{130}$

\footnotetext{
126 Niezsche, BGE, 19

${ }^{127}$ Lanier Anderson, "Nietzsche's Will to Power as a Doctrine of the Unity of Science”, p. 743.

${ }_{128}$ Nietzsche, BGE, 19.

129 It is to be noted here that Nietzsche does not consider his will to power thesis to be a mere hypothesis as Bernd Magnus suggests. Rather, we can see that Nietzsche attaches considerable epistemic weight to this doctrine. For the will to power has, in Nietzsche's view, explanatory force in both the human and the natural sciences.

${ }^{1.10}$ Lanier Anderson, "Nietzsche's Will to Power as a Doctrine of the Unity of Science", p. 744. It is to be noted that I am not here concerned with the cogency of Nietzsche's conception of the self but rather with the methodological commitments that inform it.
} 
Furthermore, we must note that by laying stress upon the importance of a structural similarity between the human and the natural sciences, Nietzsche also suggests that, the process of overcoming the opposition of self and world must include a metaphysical as well as an epistemological component. What begins as primarily an epistemological project in Nietzsche's thought can thus be seen to bear significant metaphysical repercussions. However, in making this claim I do not want to suggest that Nietzsche's epistemology constitutes metaphysics. By this I mean that Nietzsche's epistemic view regarding the unity of the sciences does not stand or fall with the cogency of the will to power metaphysics. Rather, the perspectival theory of knowledge that informs his doctrine regarding the unity of the sciences (the epistemic aspect of the will to power dealt with in part one of this chapter) stipulates that all metaphysical claims made within its parameters are regulative and open to revision. With regard to the doctrine of the will to power Nietzsche states:

And given that he too is just interpreting - and you'll be eager to raise that objection, won't you? - then, all the better. ${ }^{13 t}$

Here Nietzsche emphasizes that his own theory of the will to power ${ }^{132}$ is open to revision and objections in a similar manner to the way he has revised Boscovich's theory of forces. In so doing, Nietzsche draws our attention to his view that although epistemology precedes metaphysics when it comes to the justification of our epistemic claims, epistemology does not constitute metaphysics. Our perspectives in this sense do not literally shape reality. They merely shape our knowledge of it. Nietzsche's will to power thesis is, then, a regulative one that allows for discovery

\footnotetext{
131 Nietzsche, BGE, 22.

${ }^{132}$ Notice in BGE, 36 Nietzsche describes the doctrine of the will to power as " $m y$ tenet".
} 
and conceptual revision. ${ }^{133}$ Before I can bring my analysis to a close, however, there is one final issue pertaining to Nietzsche's will to power thesis that ought to be addressed. This is the issue of Nietzsche's relationship to Schopenhauer. In chapter three we saw that Nietzsche was struggling, with varying degrees of success, to extricate himself from Schopenhauer's metaphysics. In this chapter I have examined Nietzsche's regulative rather than dogmatic justification of the will to power. However, it will have been noticed that Nietzsche's ascription of an inner will to Boscovichean force bears strong Schopenhauerian overtones. I will conclude my examination of the will to power by demonstrating the manner in which this doctrine balances an overcoming of Schopenhauer's dogmatic metaphysics with an appreciation of Schopenhauer's overall philosophical aims.

We have seen that Nietzsche suggests that by employing "man as an analogy" ${ }^{134}$ to our understanding of the world, we are justified in ascribing an inner will to force, and thus setting up the doctrine of the will to power as an explanatory principle. He claims that a "force we cannot imagine is an empty word and should be allowed no rights of citizenship in science". ${ }^{135}$ Moreover, he maintains that the will to power captures the "intelligible character" 136 of the world. Here, we may be struck by the Schopenhauerian language that Nietzsche employs in describing the will to power.

\footnotetext{
${ }^{133}$ Thus Nietzsche draws our attention to his realist thesis by emphasizing that the doctrine of the will to power is open to criticism and change. He invites such a challenge in BGE, 22 when he claims that someone may interpret the "same nature" and "same phenomena" differently. However, Nietzsche's anti-foundationalist conception of knowledge and his view regarding the interrelatedness of all concepts (BGE, 20) ensures that any such interpretation will not radically falsify the present one but will work within its parameters and alter it from the inside. As Cox points out, any critique "can only take place from within, [--] it must draw its resources from that which it criticizes." (Cox, Nietzsche: Naturalism and Interpretation, p. 243).

${ }^{134}$ Nietzsche, WP, 619 (1885).

${ }^{135}$ Ibid., 621 (1885-1886).

${ }^{136}$ Nietzsche, BGE, 36.
} 
One may be forgiven for taking this to mean that Nietzsche endorses Schopenhauer's view of the Will after all. However, further consideration indicates that Nietzsche is evoking Schopenhauer in a provocative fashion here. For Nietzsche wants to retain some aspects of Schopenhauer's thought without committing himself to the dogmatic metaphysics that he detects there.

Schopenhauer claims that we can intuit the nature of the world as Will from our own experience of ourselves as Will. We therefore, in Schopenhauer's view, make the familiar the starting point of our investigation into the ultimate character of the world. Although Nietzsche agrees with Schopenhauer's view that our investigation must proceed "from within" 137 by employing man as an analogy, he suggests that Schopenhauer's methodology is fatally flawed. In our previous chapter we saw that from as early as 'On Schopenhauer' (1868) Nietzsche was convinced that Schopenhauer was not entitled to his particular conception of the Will. Nietzsche argues that Schopenhauer's conception of the Will is an incoherent one because it relies on the very forms of the Understanding, which Schopenhauer claims it transcends. In making this claim, Nietzsche suggests that the difficulty with Schopenhauer's conception of the Will is that Schopenhauer wants it to transcend the conditions of our knowledge whilst at the same time attempting to speak about the very thing that is beyond our knowledge. Thus the difficulty that Nietzsche is pinpointing here is the misguided nature of the philosophical practice that considers that metaphysical claims precede and ground epistemological ones. Rather Nietzsche

${ }^{137}$ Friedrich Nietzsche, "On Schopenhauer", included in Christopher Janaway (ed.), Willing and Nothingness: Schopenhouer as Nietzsche 's Educator. There Nietzsche states of Schopenhauer that "[--] it is completely correct of him to say [--- 'that we can never get at the essence of things from outside.' (paragraph 3 p. 263). 
suggests, as we saw in part one of this chapter, that epistemology must precede metaphysics if we are even to begin to talk about what the world and our position in it may be like. Therefore, I suggest that Nietzsche's claim that we should take man as an analogy is provocatively designed to make just this point. In so employing this analogy, he aims to stress his argument that explanation should be restrained within the parameters of human perspectival knowing.

However, the provocative nature of Nietzsche's use of language here also suggests that he wishes to retain some element of Schopenhauer's philosophy. In view of our earlier consideration of Nietzsche and the inner will, particularly in the context of his desire to unify both the human and the natural sciences, it is plausible that Nietzsche is motivated by Schopenhauer's desire to unify self and world. For Nietzsche shares Schopenhauer's desire to reconnect the self with the disinherited Kantian thing-in-itself. However, Nietzsche's criticisms of Schopenhauer suggest that this reconnection of self and world must take an altemative route to that taken by Schopenhauer. We saw in part one of this chapter that Nietzsche's rejection of dogmatic metaphysics entails that a strict methodology must be put in place before we can even begin to engage with the larger metaphysical issues. Thus Nietzsche's route must primarily be an epistemic one that bears metaphysical consequences. In so doing, Nietzsche concludes that the self is not radically cut off from the world, epistemically or metaphysically, to the extent that the self is now considered to be part of the world. It is in this sense that we can now fully appreciate the above mentioned Nietzschean practice of taking man as an "analogy" in interpreting the world. Richard Schacht articulates Nietzsche's reasoning here when he states: 
[---] his thinking along these lines revolves around his broader conception of something that is not a 'being' at all but a process, of which human existence is a particular but illuminating complex form: namely, life. ${ }^{138}$

This is partly what Nietzsche has in mind when he claims:

This world is will to power - and nothing besides! And you yourselves are also this will to power - and nothing besides! ${ }^{139}$

From the above we can see that Nietzsche's metaphysics is entwined with and complements his epistemic project of overcoming the opposition of self and world. Nietzsche concludes that self and world are united on both the epistemic and the metaphysical levels. However, he is aware that the epistemic level must precede the metaphysical one if he is not to fall into the same difficulties that Schopenhauer encountered. In so doing, Nietzsche considers that he has properly overcome the "problems of knowledge and metaphysics"140 that he detects in both Schopenhauer and Kant. It is on this note, then, that I will bring my investigation into Nietzsche's metaphysics to a close and proceed to my conclusion where I will assess our findings so far.

\footnotetext{
${ }^{138}$ Schacht, Nietzsche, p. 232

${ }^{139}$ Nietzsche, WP, 1067 (1885).

140 Ibid., 458 (1888).
} 


\section{Conclusion}

In this thesis I have examined Nietzsche's philosophy as a response to Kant and the particular problem of "knowledge and metaphysics"1 that he detects there. I have argued that Kant, as interpreted by Nietzsche, desires the reconciliation of the two disciplines but that Kant's formalistic epistemology and retention of the thing-in-itself results in their dissociation. The principal consequence of this dissociation, in Nietzsche's view, is the collapse of Kant's system into a sceptical idealism that disallows the possibility of making positive metaphysical claims about the nature of reality. Thus I have argued that Kant, according to Nietzsche, induces a sceptical opposition between self and world. I have further argued that Nietzsche reconnects the projects of epistemology and metaphysics by replacing sceptical idealism with, what I have called, internal realism. Internal realism has been taken to denote Nietzsche's view that we can have adequate knowledge of the world from within a perspectival and decidedly non-formalistic epistemology. Moreover, I have contended that Nietzsche is justified in making positive metaphysical claims about the ultimate nature of reality from within the parameters of his perspectivism.

My argument has been articulated in four chapters. In chapter one I outlined Nietzsche's interpretation of Kant and the problems that he associates with Kant's project. I ascertained that Nietzsche identifies three interrelated problems in Kant: the problem of form and content, the problem of the thing-in-itself and, finally, Kant's anti-naturalist thesis. The three problems, I argued, are embedded in Kant's 
distinction between constitutive knowledge and regulative belief, which, in Nietzsche's view, lead Kant into a sceptical corner from which he cannot extricate himself. I suggested that, for Nietzsche, Kant's constitutive account of knowledge separates form from content to the extent that our knowledge is deprived of a realist constraint. I also outlined Nietzsche's claim that Kant's reference to the unknowable thing-in-itself serves, contrary to Kant's own aims, to exacerbate this scepticism. Furthermore, we saw that Nietzsche argues that Kant's constitutive/regulative distinction facilitates the upholding of Kant's moral and Christian views as regulative non-cognitive beliefs. I argued that, according to Nietzsche, Kant's introduction of regulative ideas has far reaching consequences. For we saw that Nietzsche suggests that Kant's appeal to regulative non-cognitive beliefs, coupled with the failure of his constitutive account of knowledge to close the sceptical gap between self and world, disables Kant from making positive metaphysical claims about the nature of reality. This disallows, as I commented in the introduction to the thesis, a substantive treatment of the concept of force within the "Kantian" system. Furthermore, I suggested that, in Nietzsche's view, the possibility of making substantive metaphysical claims is necessary if the sceptical opposition of self and world is to be properly overcome and epistemology and metaphysics are to be reconciled.

The remaining three chapters of the thesis set about demonstrating the manner in which Nietzsche attempts to resolve the difficulties that he detects in Kant. In chapter two I examined Nietzsche's perspectival theory of knowledge as a response to, what he considers to be, Kant's metaphysical realist reference to the thing-in-

\footnotetext{
${ }^{1}$ Friedrich Nietzsche, The Will to Power, translated by Walter Kaufmann, (New York: Vintage Books, 1968), 458 (1888).
} 
itself. In particular, I demonstrated that Nietzsche's perspectivism facilitates a unification of justification and truth in contrast to their metaphysical realist dissociation. In so doing, I argued that Nietzsche's perspectivism is best understood as primarily an epistemic thesis rather than a metaphysical one. This demonstrated the non-constitutive character of his perspectival account of knowledge. Moreover, it supported my argument that Nietzsche rejects the falsification thesis. The falsification thesis maintains that the specifically human character of our knowledge may be radically in error. In contrast to such a reading, I suggested, drawing on Maudemarie Clark, that our knowledge can only be radically false if truth is conceived as that which is independent of our cognitive interests. Our cognitive interests, I suggested, provide the boundaries of intelligibility within which any claim must be shown to be false. Finally, I argued that, for Nietzsche, all our perspectival truth claims must be subject to a realist constraint. In sum, this chapter demonstrated that Nietzsche adopts an internal realist position in contrast to a metaphysical realist one. In this specific context, internal realism was taken to denote the view that our epistemic claims must be justified from "within" but that these epistemic claims are subject to a realist constraint.

In chapter three I turned to Nietzsche's "early" writings in order to demonstrate that, despite considerable interpretive difficulties, a strain of continuity can be detected across both Nietzsche's early and mature thought. Thus in this chapter I highlighted the early emergence of Nietzsche's internal realism. I argued that Nietzsche's early thought can be understood in the context of his desire to overcome the twin polarities of dogmatic realism and sceptical idealism. I argued that 
Nietzsche rejects the unmediated conception of knowledge adopted by the former and the constitutive conception adopted by the latter. I demonstrated that both dogmatic realism and sceptical idealism, in Nietzsche's view, engage in a formalistic epistemology whereby concepts, taken to be the key to knowledge, are divorced from intuitions. In contrast to both these views, I suggested that Nietzsche claims that concepts and intuitions share a reciprocal and interdependent relationship. Moreover, I traced the emergence of Nietzsche's thesis that the relationship between self and world is that of evolving part to evolving whole. This thesis, I proposed, provides Nietzsche, from an early stage, with the necessary non-constitutive framework to overcome the sceptical opposition of self and world. Finally, I argued that, for Nietzsche, art and science also share a reciprocal relationship. In so doing, I suggested that Nietzsche introduces a regulative interest-directed mode of inquiry that, in contrast to his particular interpretation of Kant, is cognitive in character.

This theme of regulative knowledge was developed further in my final chapter where I examined Nietzsche's doctrine of the will to power as both an epistemic and a metaphysical thesis. In so doing, I argued, contrary to some interpretations in the Nietzsche literature, that Nietzsche's perspectival account of knowledge allows him to make positive metaphysical claims about the nature of reality. Nietzsche succeeds in doing this, I suggested, by developing the Kantian thesis that epistemology precedes metaphysics. Thus I outlined Nietzsche's argument regarding the importance of philosophical method and economy of principles. I argued that, for Nietzsche, all metaphysical claims must be justified from "within" our perspectival framework of justification, and moreover, that their justification entails their 
adequacy to reality. However, I contended that Nietzsche, who is fully cognizant of the sceptical dangers inherent in Kant's constitutive account of knowledge, reinterprets Kant's thesis regarding the priority of epistemology over metaphysics on a regulative level. I outlined Nietzsche's view that a metaphysical claim is justified if it provides a fruitful explanation in both the human and the natural sciences. In the introduction to the thesis I presented Kant's argument which, in opposition to Herder, claims that the humanities must be relegated from the status of science on the grounds that the humanities are devoid of rigorous scholarship. My examination of Nietzsche's will to power as an epistemic thesis demonstrated that Nietzsche shares Kant's concern with scholarship and method. However, I also showed that Nietzsche thinks that a true concern with method requires considering both the perspectives of the human and the natural sciences. We saw that to relegate the human sciences from the status of rigorous scholarship, according to Nietzsche, is to mistakenly attempt to adopt an extra-perspectival viewpoint. To do so is, in his view, to attempt to step outside our specifically human manner of knowing. I argued that it is precisely this possibility that Nietzsche's perspectivism precludes.

I further argued that Nietzsche provides the justification for his 'force' metaphysics within this epistemological framework of the unity of science. Chapter four showed that, by supplementing Boscovich's concept of force with an "inner will", Nietzsche develops the will to power metaphysics as an explanation in both the human and the natural sciences. I outlined Nietzsche's view that he has, contrary to Kant's metaphysical realist appeal to an unknowable thing-in-itself, provided grounds for saving the world that "we are familiar with" both as an object of metaphysical 
inquiry and as an object of knowledge. Thus I argued that the will to power as a metaphysical thesis is designed to protect Nietzsche's internal realism. For I proposed that the will to power is introduced to provide an explanation of the happenings in the phenomenal world.

On the basis of the above findings I have shown that Nietzsche engages with epistemology in a serious way. It is often argued in the secondary literature that Nietzsche is more concerned with the axiological issue of value rather than with the epistemological issues of justification and truth. Thus it has been claimed that Nietzsche is more concerned with whether a belief enhances our life rather than with its cognitive status. Nietzsche has often been read, then, as claiming that we should satisfy ourselves with "useful fictions". However, this thesis has indicated that, contrary to such non-cognitive readings, Nietzsche is very much concerned with the epistemic status of our beliefs. This is not to disclaim the view that Nietzsche is concerned with the issues of value and meaning. But it seems to me that Nietzsche's treatment of the issue of value and his desire for life-enhancement can only work if we accept the account of his epistemology that has been offered in this thesis. For we have seen that Nietzsche regards previous metaphysical systems as having operated with a fictional conception of the world. Dualist metaphysics, Nietzsche argues, urges us to negate the world that we are familiar with in favour of a falsely promised extraempirical world. Dualist metaphysics, Nietzsche thus claims, encourages life-denial rather than affirmation. This metaphysical view trades on, according to Nietzsche, the idea of a "true" world in comparison with which the world of our experience is 
deemed false or illusory. Moreover, dualist metaphysics appeals to this "true world" to justify its denigration of the status of empirical reality.

The account of Nietzsche's epistemology put forward in this thesis suggests that dualist metaphysics, and the life-denying philosophy that ensues from it, can only be overcome by showing that this dualism is false, and that an alternative account of the nature of reality can be placed in its stead. Nietzsche is of course aware that considerably more than this is required for a successful overcoming of nihilist metaphysics. To demonstrate its falsity is not enough. Rather, we must also investigate why such a world-view and its promise of a metaphysical other-world is so attractive to us. Nietzsche engages in this type of investigation in his genealogical and psychological examinations of the ascetic ideal and ressentiment. However, it would seem that this investigation can only succeed against the background of knowing that dualist metaphysics is an incorrect interpretation of the world. It is perhaps in this sense that Nietzsche speaks of the "self-overcoming of morality through truthfulness."2 Moreover, this implies that a life-affirming disposition can only be achieved against a background of knowledge. Nietzsche indicates that this is his view when he states that "the importance of knowledge for life ought to appear as great as possible." On the basis of this we can see that Nietzsche's existentialist concerns are intertwined with his epistemological ones. I contend, therefore, that the account of Nietzsche's epistemology given in this thesis provides the necessary background against which a Nietzschean life-affirmation can take place.

\footnotetext{
${ }^{2}$ Friedrich Nietzsche, Ecce Homo, translated by R. J. Hollingdale, (London: Penguin, 1992), "Why I am a Destiny", 3.

${ }^{3}$ Friedrich Nietzsche, Human, All Too Human, translated by Marion Faber and Stephen Lehmann, (London: Penguin, 1994), 6.
} 
In this context the significance of my emphasis on Nietzsche's internal realism can now be seen. It is important for Nietzsche that our specifically human claims to knowledge are met with a realist constraint. For it is only by distinguishing between cognitive and non-cognitive beliefs that we can properly learn to affirm the world of our empirical experience. The nihilist teaches us, Nietzsche says, that the world as it is, is not as it ought to be. The world as it ought to be, can only exist as a promise in an extra-empirical realm. My examination of the reciprocal relationship between art and science in chapter three indicated that the world as it is and the world as it ought to be can be brought into harmony with one another through the idea of a realist constraint. For there we saw that art envisages how the world ought to be. Art, therefore, represents our interested engagement in the world that initiates scientific inquiry. Scientific inquiry, however, in Nietzsche's view, curbs the enthusiasm of art, ensuring that only those beliefs and interests that have passed the rigorous test of justification can be called cognitive. The reciprocal relationship between ant and science captures the essence of Nietzsche's regulative account of knowledge. It fuels his internal realism, which claims both that a belief can be considered true only if it is justified, and that its justification entails its adequacy to reality. By emphasizing the importance of the realist character of our beliefs Nietzsche thus provides the necessary epistemic background to support a life-affirming philosophy. My account of Nietzsche's epistemology can thus be seen to provide the first step in his overcoming of life-negation. The second step, which involves altering the psychological reasons for embracing life-denial, constitutes another project for which I have not the scope to treat here. I will conclude my investigation, then, by citing a 
passage that articulates Nietzsche's view that human cognitive subjects are not divorced from the world because they are immersed in the world as a smaller part in a larger whole. Moreover, this passage captures the importance of knowledge in Nietzsche's overcoming of the epistemic gap between self and world. Thus In Ecce Homo, Nietzsche outlines what Zarathustra, and thus his own philosophy, ultimately stand for:

It is at this point and nowhere else that one must make a start if one is to understand what Zarathustra's intentions are: the species of man that he delineates delineates reality as it is, he is strong enough for it - he is not estranged from or entranced by it, he is reality itself, he still has all that is fearful and questionable in reality in him, only thus can man possess greatness. ${ }^{4}$

\footnotetext{
${ }^{4}$ Nietzsche, Ecce Homo, "Why I am a Destiny", 5.
} 


\section{Bibliography}

Allen, Barry, Truth and Philosophy, (London: Harvard University Press, 1995).

Allison, David B., (ed.), The New Nietzsche: Contemporary Styles of Interpretation, (London: MIT Press, 1994).

Allison, Henry B., Kant's Transcendental Idealism: An Interpretation and Defense, (London: Yale University Press, 1983).

Ansell-Pearson, Keith, "Nietzsche's Overcoming of Kant and Metaphysics: From Tragedy to Nihilism", in Nietzsche-Studien, 1987.

Ansell-Pearson, Keith, "Nietzsche's Brave New World of Force", in Pli: The Warwick Journal of Philosophy, 9, 2000.

Arras, John D., "Art, Truth and Aesthetics in Nietzsche's Philosophy of Power", in Nietzsche-Studien. 1980.

Broad, C. D., Kant, (Cambridge: Cambridge University Press, 1978).

Brown, Richard S. G., "Nietzsche on Kant and Permanence", in Man and World, Volume $13,1980$.

Buchdahl, Gerd, Metaphysics and Philosophy of Science, (Oxford: Basil Blackwell, 1969).

Buchdahl, Gerd, Kant and the Dynamics of Reason: Essays on the Structure of Kant's Philosophy, (Oxford: Blackwell, 1992).

Clark, Maudemarie, Nietzsche on Truth and Philosophy, (Cambridge; Cambridge University Press, 1990).

Cohen, Jonathan, "Nietzsche's Fling with Positivism", in B. Babich (ed.), Nietzsche, Epistemology and Philosophy of Science, (Great Britain: Kluwer Academic Publishers, 1999).

Conard, Mark T., "Nietzsche's Kantianism", in International Studies in Philosophy, 33:3, 2001.

Conway, Daniel, "Disembodied Perspectives: Nietzsche contra Rorty", in NietzscheStudien, 1992. 
Cox, Christoph, Nietzsche: Naturalism and Interpretation, (London: University of California Press, 1999).

Crawford, Claudia, Nietzsche's Theory of Language, (New York: Walter de Gruyter, 1988).

Dancy, Jonathan, An Introduction to Contemporary Epistemology, (Oxford: Basil Blackwell, 1985).

Danto, A. C., Nietzsche as Philosopher, (New York: Macmillan, 1965).

Darby, Tom, Egyed, Bela, and Jones, Ben, (eds.), Nietzsche and the Rhetoric of Nihilism: Essays on Interpretation, Language and Politics, (Ottawa: Carleton University Press, 1989).

Davidson, Donald, "The Method of Truth in Metaphysics", in Inquiries into Truth and Interpretation, (Oxford: Oxford University Press, 1984).

Deleuze, Gilles, Nietzsche and Philosophy, translated by Hugh Tomlinson, (London: The Athlone Press, 1992).

Devitt, Michael, Realism and Truth, (Princeton: Princeton University Press, 1997).

Edwards, Jeffrey, Substance, Force, and the Possibility of Knowledge, (London: University of California Press, 2000).

French, Stanley, "Kant's Constitutive-Regulative Distinction", in Lewis White Beck (ed.), Kant Studies Today, (Illinois: Open Court, 1969).

Friedman, Michael, Kant and the Exact Sciences, (Cambridge: Harvard University Press, 1992).

Gardiner, Patrick, Schopenhauer, (Middlesex: Penguin, 1963).

Gardner, Sebastian, Kant and The Critique of Pure Reason, (London: Routledge, 1999).

Gemes, Ken, "Nietzsche's Critique of Truth", in Philosophy and Phenomenological Research, 1992.

Geuss, Raymond, “Nietzsche and Genealogy”, in European Journal of Philosophy, 1994.

Gram, Moltke, "Things in Themselves: The Historical Lessons", in Journal of the History of Philosophy, 1980. 
Grimm, Rüdiger Hermann, Nietzsche's Theory of Knowledge, (Berlin: Walter de Gruyter, 1977).

Harré, R, and Madden, E. H., Causal Powers: A Theory of Natural Necessity, (Oxford: Basil Blackwell, 1975).

Haldane, John, "Mind-World Identity Theory and the Anti-Realist Challenge", in John Haldane and Crispin Wright (eds.), Reality, Representation and Projection, (Oxford: Oxford University Press, 1993).

Hales, Steven, and Welshon, Rex, Nietzsche's Perspectivism, (Urbana: University of Illinois Press, 2000).

Hollingdale, R. J., Nietzsche: The Man and his Philosophy, (London: Routledge and Kegan Paul, 1965).

Houlgate, Stephen, Hegel. Nietzsche, and the Criticism of Metaphysics, (Cambridge: Cambridge University Press, 1986).

Houlgate, Stephen, "Kant, Nietzsche, and the "Thing-in-Itself", in Nietzsche-Studien, 1993.

Hume, David, A Treatise of Human Nature, (Oxford; Oxford University Press, 1992).

Jammer, Max, Concepts of Force: A Study in the Foundation of Dynamics, (Cambridge: Harvard University Press, 1957).

Janaway, Christopher, Self and World in Schopenhauer's Philosophy, (Oxford: Clarendon Press, 1989).

Janaway, Christopher (ed.), Willing and Nothingness: Schopenhauer as Nietzsche's Educator, (Oxford: Clarendon Press, 1998).

Jaspers, Karl, Nietzsche: An Introduction to the Understanding of his Philosophical Activity, translated by Charles F. Wallraff and Frederick J. Schmitz, (London: The John Hopkins University Press, 1997).

Johnston, Mark, "Objectivity Refigured: Pragmatism Without Verificationism", in John Haldane and Crispin Wright (eds.), Reality, Representation and Projection, (Oxford: Oxford University Press, 1993).

Kant, Immanuel, Critique of Pure Reason, translated by Norman Kemp Smith, (London: Macmillan Press, 1929). 
Kant, Immanuel, (ritique Of Judgement, translated by James Creed Meredith, (Oxford: Clarendon Press, 1991).

Kant, Immanuel, Prolegomena to any Future Metaphysics, translated by Paul Carus, (Cambridge: Hackett Publishing Company, 1977).

Kaufmann, Walter, Nietzsche: Philosopher, Psychologist, Antichrist, (New Jersey: Princeton University Press, 1974).

Klein, Peter D., "Radical Interpretation and Global Skepticism", in Ernest LePore (ed.), Truth and Interpretation, (Oxford: Basil Blackwell, 1986).

Kulp, Christopher B. (ed.), Realism/Anti-Realism and Epistemology, (Oxford: Rowman and Littlefield Publishers, 1997).

Langton, Rae, Kantian Humility: Our Ignorance of Things in Themselves, (Oxford: Clarendon Press, 1998).

Lanier Anderson, R., "Nietzsche's Will to Power as a Doctrine of the Unity of Science", in Studies in History and Philosophy of Science, Volume 25, 1994.

Lanier Anderson, R., "Overcoming Charity: The Case of Maudemarie Clark's Nietzsche on Truth and Philosophy", in Nietzsche-Studien, 1996.

Magnus, Bernd, Nietzsche's Existential Imperative, (London: Indiana University Press, 1978).

Magnus, Bernd, “Nietzsche's Mitigated Scepticism”, in Nietzsche-Studien, 1980.

Magnus, Bernd, "Nietzsche and Postmodern Criticism", in Nietzsche-Studien, 1989.

May, Simon, Nietzsche's Ethics and his War on 'Morality', (Oxford: Clarendon Press, 1999).

McDowell, John, Mind and World, (Cambridge: Harvard University Press, 1996).

Mittelman, Willard, "The Relation between Nietzsche's Theory of the Will to Power and his Earlier Conception of Power", in Nietzsche-Studien, 1980.

Moles, Alistair, Nietzsche's Philosophy of Nature and Cosmology, (New York: Peter Lang, 1990).

Moore, A.W., Points of View, (Oxford: Clarendon, 1997).

Nehamas, Alexander, Life as Literature, (London: Harvard University Press, 1985). 
Neiman, Susan, The Unity of Reason: Rereading Kant, (New York: Oxford University Press, 1994).

Nietzsche, Friedrich, The Birth of Tragedy, translated by Shaun Whiteside, (London: Penguin, 1993).

Nietzsche, Friedrich, The Birth of Tragedy and Other Writings, translated by Ronald Speirs, (Cambridge: Cambridge University Press, 1999).

Nietzsche, Friedrich, Philosophy and Truth: Selections from Nietzsche's Notebooks of the Early 1870 's, edited and translated by Daniel Breazeale, (London: Humanities Press, 1993).

Nietzsche, Friedrich, "Homer's Contest", in The Portable Nietzsche, edited and translated by Walter Kaufmann, (London: Chatto and Windus, 1971).

Nietzsche, Friedrich, Untimely Meditations, translated by R. J. Hollingdale, (Cambridge: Cambridge University Press, 1994).

Nietzsche, Friedrich, Assorted Opinions and Maxims, Volume II, Part One of Human, All Too Human, translated by R. J. Hollingdale, (Cambridge: Cambridge University Press, 1986).

Nietzsche, Friedrich, Human, All Too Human, translated by Marion Faber and Stephen Lehmann, (London: Penguin, 1994).

Nietzsche, Friedrich, Daybreak: Thoughts on the Prejudices of Morality, translated by R. J. Hollingdale, (Cambridge: Cambridge University Press, 1993).

Nietzsche, Friedrich, The Gay Science, translated by Walter Kaufmann, (New York: Vintage Books, 1974).

Nietzsche, Friedrich, Thus Spoke Zarathustra, translated by R. J. Hollingdale, (London: Penguin, 1969).

Nietzsche, Friedrich, Beyond Good and Evil, translated by R. J. Hollingdale, (London: Penguin, 1990).

Nietzsche, Friedrich, Beyond Good and Evil, translated by Marion Faber, (Oxford: Oxford University Press, 1998).

Nietzsche, Friedrich, On the Genealogy of Morality, translated by Carol Diethe, (Cambridge: Cambridge University Press, 1994). 
Nietzsche, Friedrich, On the Genealogy of Morality, translated by Maudemarie Clark and Alan J. Swensen, (Indianapolis: Hackett Publishing Company, 1998).

Nietzsche, Friedrich, Twilight of the Idols/The Anti-Christ, translated by R. J. Hollingdale, (London: Penguin, 1990).

Nietzsche, Friedrich, Twilight of the Idols, translated by Duncan Large, (Oxford: Oxford University Press, 1998).

Nietzsche, Friedrich, Ecce Homo, translated by R. J. Hollingdale, (London: Penguin, 1992).

Nietzsche, Friedrich, The Will to Power, translated by Walter Kaufmann, (New York: Vintage Books, 1968).

Nola, Robert, "Nietzsche's Naturalism: Science and Belief", in B. Babich (ed.), Nietzsche, Epistemology and Philosophy of Science, Volume I, (Great Britain: Kluwer Academic Publishers, 1999).

Owen, David, Nietzsche, Politics and Modernity, (London: Sage Publications, 1995).

Poellner, Peter, Nietzsche and Metaphysics, (Oxford: Clarendon Press, 1995).

Poellner, Peter, "Causation and Force in Nietzsche", in B. Babich (ed.), Nietzsche, Epistemology and Philosophy of Science, Volume II, (Great Britain: Kluwer Academic Publishers, 1999).

Poellner, Peter, "Perspectival Truth", in John Richardson and Brian Leiter (eds.), Nietzsche, (Oxford: Oxford University Press, 2001).

Porter, James I., The Invention of Dionysus: An Essay on The Birth of Tragedy, (Stanford: Stanford University Press, 2000).

Putnam, Hilary, Reason, Truth and History, (Cambridge: Cambridge University Press, 1984).

Putnam, Hilary, The Many Faces of Realism, (Illinois: Open Court, 1991).

Rescher, Nicholas, A System of Pragmatic Idealism, Volume I, (Princeton: Princeton University Press, 1992).

Rescher, Nicholas, Kant and the Reach of Reason: Studies in Kant's Theory of Rational Systemization, (Cambridge: Cambridge University Press, 2000). 
Rethy, Robert, "Schein in Nietzsche's Philosophy", in Keith Ansell-Pearson (ed.), Nietzsche and Modern German Thought, (London: Routledge, 1991).

Rethy, Robert, "The Tragic Affirmation of The Birth of Tragedy", in Nietzsche-Studien, 1998.

Ridley, Aaron, Nietzsche 's Conscience, (London: Cornell University Press, 1998).

Rorty, Richard, Consequences of Pragmatism, (New York: Harvester Wheatsheaf, 1982).

Rorty, Richard, "Realism, Antirealism, and Pragmatism: Comments on Alston, Chisholm, Davidson, Harman, and Searle", in Christopher B. Kulp (ed.), Realism Antirealism and Epistemology, (Oxford: Rowman and Littlefield Publishers, 1997).

Rosenberg, J. F., One World and Our Knowledge of It: The Problem of Realism in PostKantian Perspective, (Dordrecht, Holland: D. Reidel Publishing Company, 1980).

Rotenstreich, Nathan, Experience and its Systematization: Studies in Kant, (The Hague: Martinus Nijhoff, 1965).

Schacht, Richard, Nietzsche, (London: Routledge and Kegan Paul, 1983).

Schacht, Richard, Nietzsche, Genealogy, Morality, (London: University of California Press, 1994).

Schopenhauer, Arthur, The World as Will and Representation, Volume I, translated by E. F. J. Payne, (New York: Dover, 1966).

Schopenhauer, Arthur, The World as Will and Representation, Volume II, translated by E. F. J. Payne, (New York: Dover, 1966).

Schrift, Alan D., Nietzsche and the Question of Interpretation, (New York: Routledge, 1990).

Silk, M. S., and Stern, J. P., Nietzsche and Tragedy, (Cambridge: Cambridge University Press, 1981).

Solomon, Robert C., and Higgins, Kathleen M., Reading Nietzsche, (Oxford: Oxford University Press, 1988).

Sosa, Ernest, "Putnam's Pragmatic Realism", in The Journal of Philosophy, Volume xc, No. 12, 1993.

Stack, George J., Lange and Nietzsche (Berlin: Walter de Gruyter, 1983). 
Stack, George J., "Kant, Lange, and Nietzsche: Critique of Knowledge", in Keith AnsellPearson (ed.), Nietzsche and Modern German Thought, (London: Routledge, 1991).

Strawson, P. F, The Bounds of Sense, (London: Routledge, 1991).

Stroud, Barry, Hume, (London: Routledge, 1991).

Taylor, Charles Senn, “Nietzsche's Schopenhauerianism”, in Nietzsche-Studien, 1988.

Tipton, I. C., Berkeley: The Philosophy of Immaterialism, (London: Methuen and Co., 1976).

Van Tongeren, Paul J. M., "Nietzsche's Symptomatology of Skepticism", in B. Babich (ed.), Nietzsche, Epistemology and the Philosophy of Science: Nietzsche and the Sciences, Volume II, (Great Britain: Kluwer Academic Publishers, 1999).

West, Cornel, "Nietzsche's Prefiguration of Postmodern American Philosophy", in Daniel O' Hara (ed.), Why Nietzsche Now?, (New York: Indiana University Press, 1985).

Wilcox, John T., Truth and Value in Nietzsche, (Ann Arbor: The University of Michigan Press, 1974).

Wilcox, John T., "Nietzsche Scholarship and "The Correspondence Theory of Truth": the Danto Case", in Nietzsche-Studien, 1986.

Wilkerson, T. E., "Kant on Objectivity", in Midwest Studies in Philosophy, VIII, (Minneapolis: University of Minnesota Press, 1983).

Williams, Michael, Groundless Belief: An Essay on the Possibility of Epistemology, (Princeton: Princeton University Press, 1999).

Williams, Michael, "Realism and Scepticism" in John Haldane and Crispin Wright (eds.), Reality, Representation and Projection, (Oxford: Oxford University Press, 1993).

Williams, Michael, Unnatural Doubts: Epistemological Realism and the Basis of Scepticism, (Oxford: Basil Blackwell, 1991).

Wolff, Robert Paul, Kant's Theory of Mental Activity, (Cambridge, Massachusetts: Harvard University Press, 1969).

Zammito, John H., The Genesis of Kant's Critique of Judgment, (London: The University of Chicago Press, 1992). 